UNIVERSIDADE DE SÃO PAULO

FACULDADE DE FILOSOFIA, LETRAS E CIÊNCIAS HUMANAS

PROGRAMA DE PÓS-GRADUAÇÃO EM GEOGRAFIA HUMANA

\title{
TURISMO, TERRITÓRIO E MODERNIDADE: \\ Um Estudo da População Indígena Krahô, Estado do Tocantins (Amazônia Legal Brasileira)
}

\author{
Vanderlei Mendes de Oliveira
}

\begin{abstract}
Tese apresentada ao Programa de Pós-Graduação em Geografia Humana, do Departamento de Geografia da Faculdade de Filosofia, Letras e Ciências Humanas da Universidade de São Paulo, para obtenção do título de Doutor em Geografia.
\end{abstract}

Orientadora: Profa. Dra. Adyr Apparecida Balastreri Rodrigues 
BANCA EXAMINADORA 
À minha mãe, Otacília Frankilina Alves, pelo carinho e pela presença nas horas dificeis. À Regina Célia Padovan, minha esposa. À Ana e à Tarcila, minhas filhas. 


\section{AGRADECIMENTOS}

Ao Programa de Pós-Graduação em Geografia Humana (FFLCH - USP)

À Fundação Coordenação de Aperfeiçoamento de Pessoal de Nível Superior CAPES, pela bolsa concedida, sem a qual não teria sido possível concluir esta tese.

À Fundação Universidade Federal do Tocantins, em especíco à Pró-Reitoria de Pesquisa e Pós-Graduação, pelo apoio e incentivo institucional.

À Fundação Nacional do Índio - FUNAI, pelos dados e informações sobre as populações indígenas brasileiras.

À Kapey- União das Aldeias Krahô, pelos dados e informações sobre os Krahô.

À Adyr App. Balastreri Rodrigues, por ter aceitado orientar esta tese e pelos comentários em todas as suas etapas.

Ao Christiam Dennis de Oliveira, pelas sugestões em todos os momentos da tese.

Ao Paulo Nunes, pela recepção na USP e na Cidade de São Paulo.

Ao Celso Henrique Acker, pela amizade e companheirismo.

À Eliana Henriques Moreira, pelas colaborações na UFT- Campus Universitário de Tocantinópolis (TO).

Ao Aroldo Magno de Oliveira e à Alice Akemi Yamasaki, da UFT- Campus Universitário de Tocantinópolis (TO), pelo incentivo e companheirismo.

Aos Povos Indígenas Krahô, por terem aceitado e contribuído no desenvolvimento desta tese.

Ao Fernando Schiavini, pelas colaborações e discussões sobre os projetos Krahô.

Ao Getúlio Orlando Krahô, pela colaboração e participação na tese.

Ao Feliciano Tep Hot, pela colaboração e participação na tese.

Ao Emerson Ferreira Guerra, pela colaboração e participação na tese.

Aos docentes da UFT- Campus Universitários de Tocantinópolis (TO).

Aos alunos da UFT- Campus Universitário de Tocantinópolis (TO).

Ao Ademir Chiovetti Padovan, pela colaboração e participação na tese.

À Valéria Medeiros de Andrade, pelo trabalho e profissionalismo com os Krahô.

Ao Cleso Fernandes de Moraes, pelo trabalho e profissionalismo na Funai-Araguaina.

Ao Paulo Cézar Alexandre da Silva e à Vera Lúcia Padovam, pela recepção na Cidade de São Paulo. 


\section{RESUMO}

Esta tese tem a finalidade de apresentar estudos sobre o turismo, o território e a modernidade. Para isto, realiza-se um debate teórico e metodológico sobre os usos dos diferentes conceitos de território. Dentro desta lógica, insere-se o turismo como alavanca do desenvolvimento com base local. De uma parte, analisa-se o turismo indígena e, de outra, estuda-se o turismo em territórios indígenas. A metodologia utilizada na pesquisa de campo divide-se entre os estudos etnológicos, etnográficos, pesquisa-ação, pesquisa-participante e a literatura sobre turismo e desenvolvimento com base local. O trabalho de campo entre os Krahô ocorreu entre os anos de 2004, 2005 e 2006, permitindo levantar informações sobre a ocorrência do turismo nas comunidades e associações indígenas, assim como propor o entendimento sobre o turismo nos sentidos econômico, político, cultural e ambiental. O turismo emissivo indígena pode ser definido como aquele em que os indígenas das várias etnias viajam para as cidades locais, regionais, nacionais e internacionais para participarem de eventos (Jogos Indígenas, etc.). O turismo em territórios indígenas se define como aquele que ocorre no interior dos territórios indígenas (Feira Krahô de Sementes Tradicionais, etc.). Os territórios das populações autóctones no Brasil estão adquirindo sentido de territórios descontínuos e de territórios-rede, pois todas as etnias possuem mobilidades de seus territórios para outras territorialidades. Portanto, tanto o turismo emissivo indígena quanto o turismo receptivo em territórios indígenas contribuem para a construção da elevação da auto-estima dos índios, para a venda do artesanato e, por último, para a constituição de novas multiterritorialidades turísticas.

Palavras-Chave: Turismo Indígena, Turismo em Territórios Indígenas, Desenvolvimento com base Local, Comunidades Indígenas e Associações Indígenas. 


\begin{abstract}
This thesis aims at submitting studies about tourism, territory and modernity. For such, a theoretical and methodological debate on the uses of the different territory concepts takes place. Within this logic, tourism is inserted as development with local base. On the one hand, we analyze indigenous tourism, and on the other hand, we study tourism in indigenous territories. The methodology used in the field research is divided among ethnologic, ethnographic studies, research-action, research-participant and the literature on tourism and development with local base. The field work among the Krahô took place between the years 2004, 2005 and 2006, allowing to survey information on the occurrence of tourism in the indigenous communities and associations, as well as proposing the understanding on tourism in the economical, political, cultural and environmental senses. The emissive indigenous tourism can be defined as the one where the natives of the different ethnic groups travel to the local, regional, national and international cities to take part in events (Indigenous Games, etc.). The tourism in indigenous territories is defined as the one taking place within the indigenous territories (Krahô Fair of Traditional Seeds, etc.). The territories of the autochthonous populations in Brazil are acquiring sense of discontinuous territories and network-territories, because all the ethnic groups can move from their territories to other territories. Therefore, both emissive indigenous tourism as well as the receptive tourism in indigenous territories contribute for elevating the self-esteem of the Indians, for selling handicraft and, for last, for constituting new multi-territory tourism.
\end{abstract}

Key Words: Indigenous tourism, Tourism in Indigenous Territories, Local Development, Indigenous Communities and Indigenous Associations. 


\section{RÉSUMÉ}

Cette thèse a comme objectif celui de présenter des études sur le tourisme, le territoire et la modernité. Pour cela, on réalise un débat théorique et méthodologique sur les usages des différents concepts de territoire. Dans cette logique, s'insère le tourisme comme développement avec base locale. D'une part, on analyse le tourisme indigène et, d'autre part, on étudie le tourisme dans des territoires indigènes. La méthodologie utilisée dans la recherche sur le terrain se partage entre les études ethnologiques, ethnographiques, rechercheaction, recherche-participante et la littérature sur le tourisme et développement avec base local. Le travail sur le terrain parmi les Krahô s'est passé entre les années 2004, 2005 et 2006, ce qui a permis d'obtenir de informations sur l'occurrance du tourisme dans les communautés et associations indigènes, ainsi comme proposer la compréhension sur le tourisme dans les sens économique, politique, culturel et d'environement. Le tourisme émissif indigène peut être defini comme celui ou les indigènes de plusieurs ehtnies voyagent pour les villes locales, régionales, nationales et internacionales pour participer d'évenements (Jeux Indigènes, etc.). Le tourisme dans des territoires indigènes se défine comme celui qui se passe à l'intérieur des territoires indigènes (Marché Krahô de Semences Traditionneles, etc.). Les territoires des populations autochtones au Brésil sont en train d'obtenir du sens de territoires discontinus et de territoires-réseau, puisque toutes les ethnies ont la mobilité de leurs territoires pour d'autres territoiretés. Donc, autant le tourisme émissif indigène comme le tourisme receptif en territoires indigènes contribuent pour la construction de l'augmentation de l'auto-estime des indiens, pour la vente de l'artesanat et, en dernier, pour la constitution de nouvelles multiterritorialités touristiques.

Mots-clés: Tourisme Indigène, Tourisme dans de Territoires Indigènes, Développement Local, Communautés Indigènes et Associations Indigènes. 


\section{SUMÁRIO}

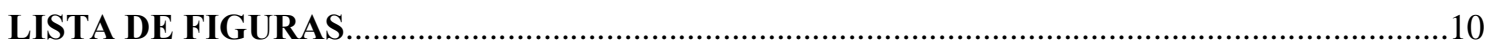

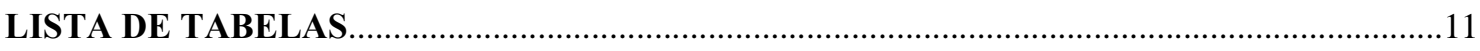

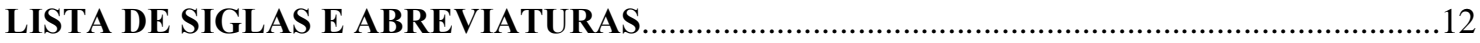

INTRODUÇÃO

CAPÍTULO 1 - O TURISMO COMO UM TEMA DE PESQUISA INTERDISCIPLINAR.......18

1.1 OS USOS DOS DIFERENTES CONCEITOS DE TERRITÓRIO..............................................

1.2 ANÁLISE DO CONCEITO DE TERRITÓRIO E O USO DO TERMO

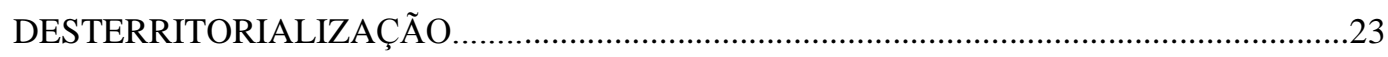

1.3 TERRITORIALIZAÇÃO, DESTERRITORIALIZAÇÃO E RETERRITORIALIZAÇÃO.......25

1.4 HIBRIDIZAÇÃO DAS CULTURAS, MOBILIDADE E I-MOBILIDADE SOCIAL.................33

1.5 CULTURAS HÍBRIDAS, TURISMO, MODERNIDADE E PÓS-MODERNIDADE...............42

\section{CAPÍTULO 2 - TURISMO, TERRITÓRIO, MODERNIDADE E DESENVOLVIMENTO}

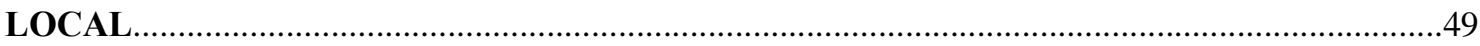

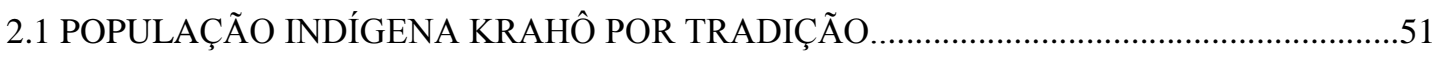

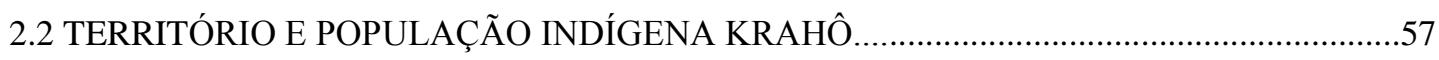

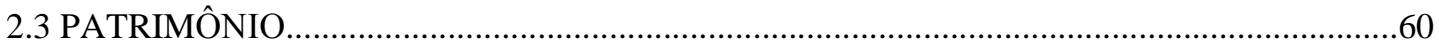

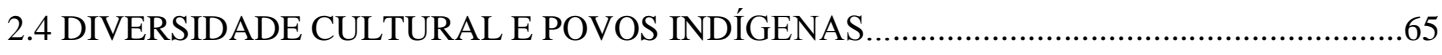

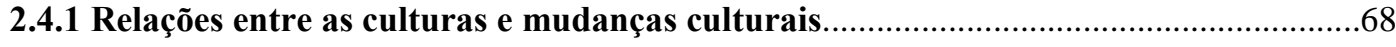

2.5 O DESENVOLVIMENTO COM BASE LOCAL.................................................................

2.6 CONTRIBUIÇÕES DO TURISMO PARA O DESENVOLVIMENTO LOCAL......................75

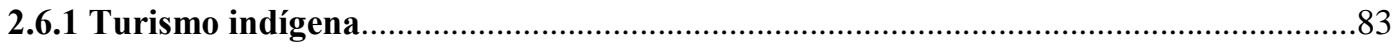

2.6.1.1 Jogos das Populações Indígenas.....................................................................................90

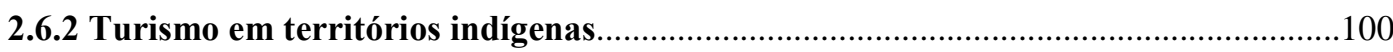


2.7 ATRIBUIÇÃO DE NOMES AOS VISITANTES (AOS TURISTAS)

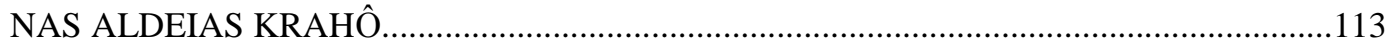

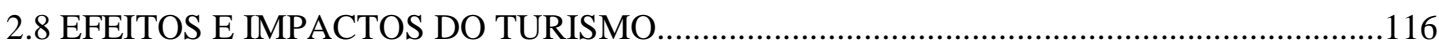

\section{CAPÍTULO 3 - PROJETOS INDÍGENAS KRAHÔ, DESENVOLVIMENTO}

SÓCIO-ESPACIAL E A ORGANIZAÇÃO DO TURISMO.

3.1 PROJETO CONSERVAÇÃO E USO DE RECURSOS GENÉTICOS NA TERRA

KRAHÔ. .122

3.1.1 Coleta, Caracterização e Conservação de Recursos Genéticos .123

3.1.2 Inter-relação entre o Conhecimento Tradicional e o Conhecimento Científico.

3.1.3 Introdução, Reintrodução e Translocação de Materiais Genéticos na Terra Krahô

3.1.4 Uso, Manejo e Conservação de Solos na Terra Krahô.

3.1.5 Documentação e Difusão do Projeto

3.2 PROJETO ESCOLA CATXÊKWYJ - VIVÊNCIA AGRO-AMBIENTAL...............................124

3.3 PROJETO DE DESENVOLVIMENTO INTEGRADO SOCIAL KRAHÔ (PDISK)...............126

3.4 PROJETO RESGATE, VALORIZAÇÃO E COMERCIALIZAÇÃO

DO ARTESANATO KRAHÔ. 126

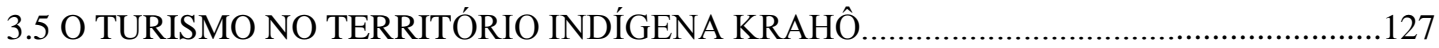

3.6 FEIRAS KRAHÔ DE SEMENTES, TURISTAS E ACAMPAMENTO..................................147

3.6.1 Artesanato Krahô, Feiras Krahô de Sementes Tradicionais e o turismo.....................162

3.7 IMPASSES EXISTENTES ENTRE EMBRATUR, FUNAI, MMA E POPULAÇÕES

INDÍGENAS BRASILEIRAS. .167

3.8 A CONSTRUÇÃO DE MATERIAL DIDÁTICO SOBRE O TURISMO

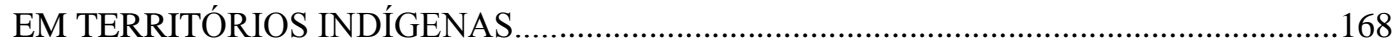

3.9 AS ASSOCIAÇÕES INDÍGENAS KRAHÔ E A ORGANIZAÇÃO DO TURISMO..............170

À GUISA DA CONCLUSÃO .173

REFERÊNCIAS .176

ANEXOS. 188 


\section{LISTA DE FIGURAS}

Figura 01 - Placa com informações sobre legislação dos territórios (terras) indígenas...........................41

Figura 02 - Terra Indígena Krahô, Localização das Aldeias e Circulação............................................61

Figura 03 - Os ritos do ciclo anual e os ligados à iniciação...................................................................64

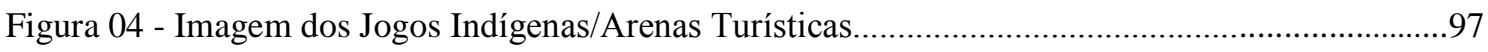

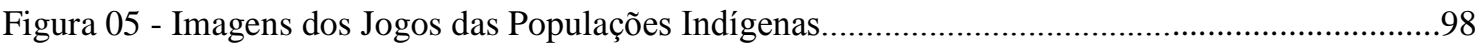

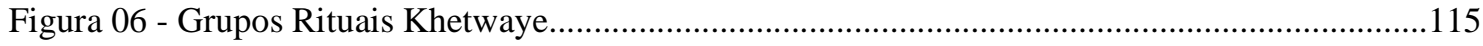

Figura 07 - Posição dos Grupos Rituais que participam do Khetwaye.................................................115

Figura 08 - Escola Catxêkwyj - Vivência Agroambiental............................................................125

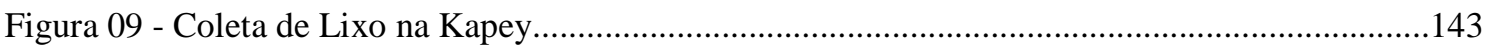

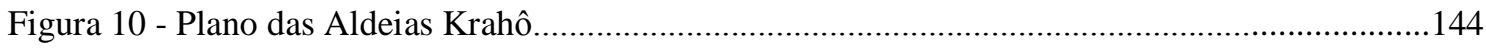

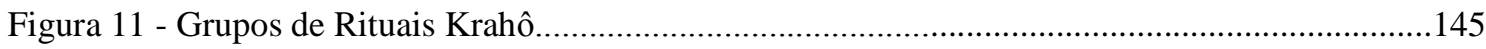

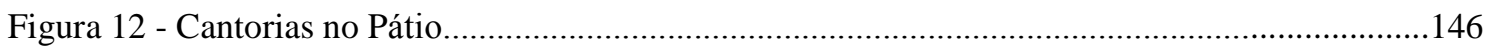

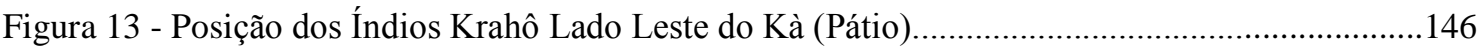

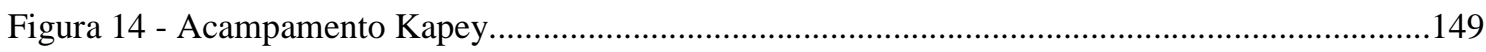

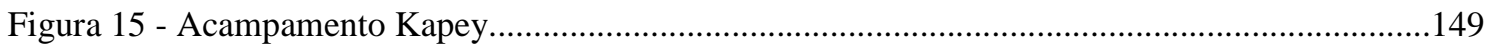

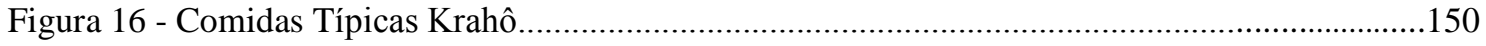

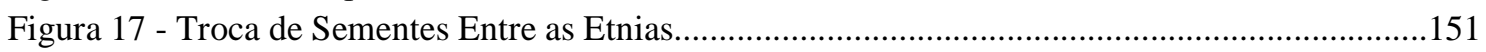

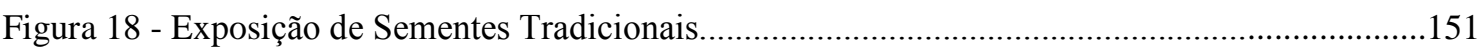

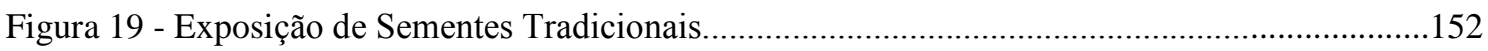

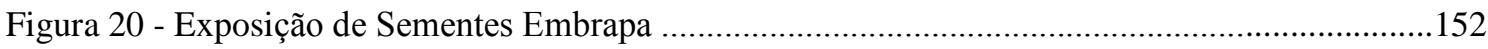

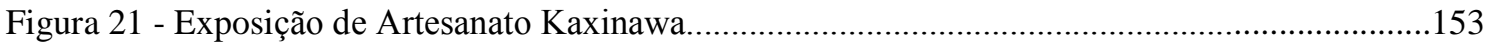

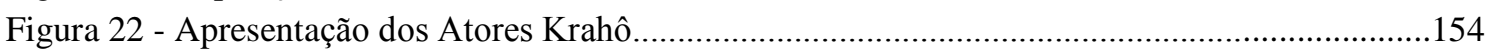

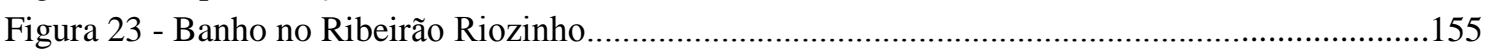

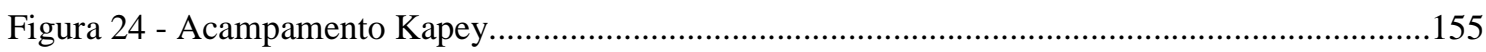

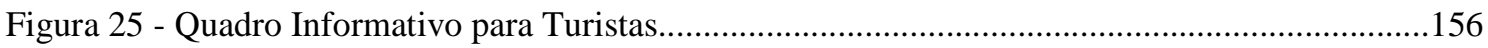

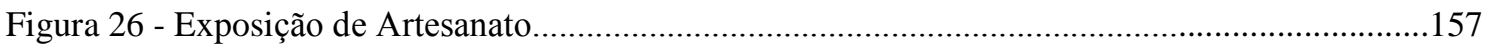

Figura 27 - Troca de Sementes entre os Krahô e os Kaxinawa.............................................................158

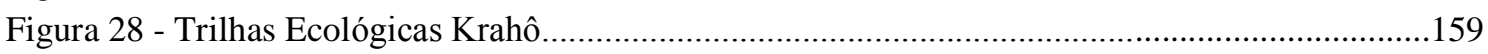

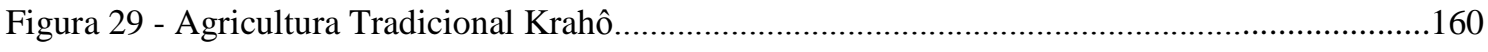

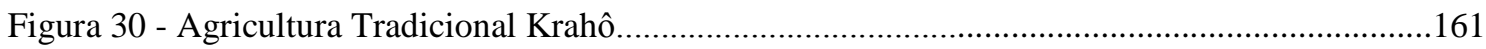

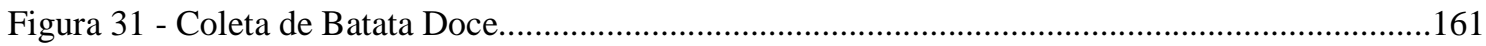

Figura 32 - Método de Conservação de Espécies de Mandioca para o plantio.......................................162

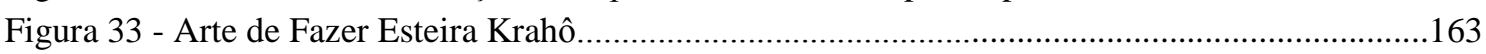

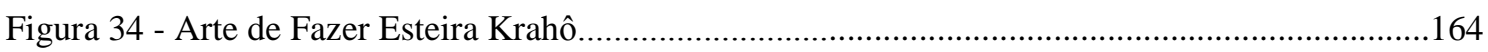

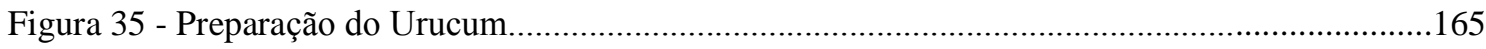

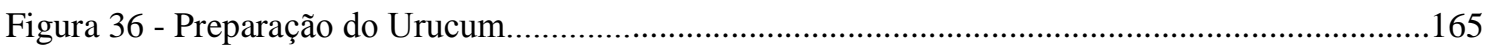

Figura 37 - Urucum Preparado para Fazer as Pinturas Corporais Durante os Rituais...........................166 


\section{LISTA DE TABELAS}

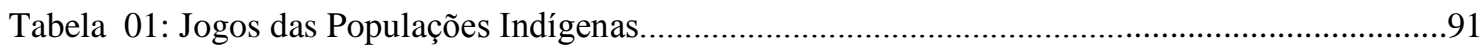

Tabela 02: Projetos Desenvolvidos pela Kapey-União das Aldeias Krahô..........................................122

Tabela 03: Relação das Aldeias Krahô e População...........................................................................140

Tabela 04: Feiras de Sementes realizadas no território indígena Krahô................................................147

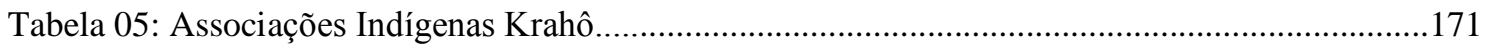




\title{
LISTA DE SIGLAS E ABREVIATURAS
}

\author{
AGB/SP - Associação dos Geógrafos Brasileiros- Seção São Paulo \\ ANPEGE - Associação Nacional de Pós-Graduação e Pesquisa em Geografia \\ BNDES - Banco Nacional de Desenvolvimento Econômico e Social \\ COIAB - Coordenação das Organizações Indígenas da Amazônia Brasileira \\ COIAT - Coordenação das Organizações Indígenas da Bacia do Araguaia-Tocatins \\ CTI - Centro do Trabalhador Indigenista \\ ECA-USP - Escola de Comunicação e Artes \\ EGAL - Encontro de Geógrafos da América Latina \\ EMBRAPA - Empresa Brasileira de Pesquisa Agropecuária-Cerrados \\ EMBRATUR - Empresa Brasileira do Turismo \\ ENTBL - Encontro Nacional de Turismo com Base Local \\ FUMDHAM/PI - Fundação do Museu do Homem Americano, Estado do Piauí \\ FUNAI - Fundação Nacional do Índio \\ FUNASA - Fundação Nacional de Assistência a Saúde \\ FFLCH-USP - Faculdade de Filosofia, Letras e Ciências da Universidade de São Paulo \\ IBAMA - Instituto Brasileiro do Meio Ambiente e Recursos Renováveis \\ IEB-USP - Instituto de Estudos Brasileiros da Universidade de São Paulo \\ KAPEY - União das Aldeias Krahô \\ MAE-USP - Museu de Arqueologia e Etnologia da Universidade de São Paulo \\ MDA - Ministério do Desenvolvimento Agrário \\ MDS - Ministério do Desenvolvimento Social \\ MMA - Ministério do Meio Ambiente \\ NAEA-UFPA - Núcleo de Altos Estudos Amazônicos \\ NEHO-USP - Núcleo de História Oral da Universidade de São de Paulo \\ ONG's - Organizações Não-Governamentais \\ PDISK - Projeto de Desenvolvimento Social Integrado Krahô \\ PDPI - Projetos Demonstrativos dos Povos Indígenas \\ PIB - Produto Interno Bruto \\ PROLAM-USP - Programa de Pós-Graduação em Integração de América Latina da Universidade de São Paulo \\ SEPEGE-USP - Seminário de Pós-Graduação em Geografia \\ SICTUR/TO - Secretaria Estadual de Indústria, Comércio e Turismo do Estado do Tocantins \\ SPI-DF - Serviço de Proteção ao Índio \\ UFG-GO - Universidade Federal de Goiás \\ UFPA-PA - Universidade Federal do Pará \\ UFPR-PR - Universidade Federal do Paraná \\ UFT-TO - Universidade Federal do Tocantins \\ UFU-MG - Universidade Federal de Uberlândia \\ UNB-DF - Universidade de Brasília \\ UNITINS-TO - Fundação Universidade do Tocantins \\ USP - Universidade de São Paulo
}




\section{INTRODUÇÃO}

Com a pesquisa de campo realizada entre os anos de 2004, 2005 e 2006 junto à população indígena Krahô, foi possível identificar que o turismo em territórios indígenas pode ser considerado uma realidade. Durante o levantamento bibliográfico sobre os Krahô, pôde-se encontrar alguns trabalhos com um conteúdo bastante contundente acerca da estrutura social e econômica desta população. O trabalho de pesquisa, publicado sob a forma de livro, de Melatti (1978) intitulado "Ritos de uma tribo Timbira" muito contribuiu para a compreensão das relações interétnicas e interculturais da população indígena Krahô com a sociedade envolvente.

A proposição de que a população Krahô já possui um projeto de gestão do turismo em territórios indígenas com algumas décadas de experiência motiva o desenvolvimento desta pesquisa, que tem por objetivo apresentar algumas contribuições para a organização do turismo em territórios indígenas, seguindo a lógica do método da pesquisa-ação e da pesquisaparticipante.

Pode-se considerar que em todos os territórios indígenas existe alguma forma de turismo. Ao mesmo tempo em que este pode ser interpretado como estando em sua fase inicial de organização, pode-se entender que sua ordenação já está posta na estrutura social e econômica das populações indígenas brasileiras, o que permite que elas recebam turistas (Pesquisadores, Jornalistas, Ecologistas, Professores, Alunos Secundaristas das Escolas Públicas, Estudantes Universitários, Missionários, entre outros).

O turismo em territórios indígenas segue a lógica do desenvolvimento com base local, sendo que as comunidades indígenas são as responsáveis pela gestão do turismo em seus territórios. Aqui o melhor exemplo a ser citado é o da organização do turismo no território indígena Krahô - conhecido no país e no exterior (com prêmios recebidos ${ }^{1}$ ) - em outras atividades que estão ligadas diretamente ao modelo de gestão do turismo.

Por um lado, considera-se que o turismo no território indígena Krahô é uma atividade econômica importante e, por outro, destaca-se que a organização do turismo é uma necessidade, pois o povo Krahô possui uma experiência acumulada no desenvolvimento de

\footnotetext{
${ }^{1}$ Prêmios Recebidos: 1) Fundação Getúlio Vargas - "Ação Pública e Cidadania" em 1998; e 2) Slow Food - "Prêmio Slow Food em defesa da agrobiodiversidade", Nápoles, Itália - 2003.
} 
projetos (financiamento e pesquisa). Por isso, o território indígena Krahô é bastante visitado por populações indígenas de outras etnias, pesquisadores, professores, estudantes universitários, missionários e aventureiros.

Nesse sentido, o turismo pode aumentar a renda das comunidades indígenas e contribuir para a realização de projetos que venham a proporcionar o seu desenvolvimento sócio-espacial (com base local). A análise do turismo no território indígena Krahô está sendo construída nos sentidos econômico, político, cultural e ambiental. Os usos dos diferentes conceitos de território (mencionados no item 1.2, do Capítulo 1) indicam a priori a necessidade de se construir uma abordagem do turismo seguindo a lógica das variadas concepções. Trata-se de um esforço de análise complexo, pois se acrescentam outros novos termos, entre os quais: desterritorialização, reterritorialização e multiterritorialidades.

Uma questão que se coloca sobre o turismo em territórios indígenas se restringe à seguinte indagação: os turistas que praticam o turismo em terras indígenas podem ser incluídos dentro da lógica do mito da desterritorialização e da reterritorialização? Para responder esta questão, faz-se necessário compreender o turismo em territórios indígenas seguindo a lógica dos usos dos diferentes conceitos de território e propor uma análise integradora do turismo com o território.

A elaboração de uma proposta para disciplinar a organização do turismo em territórios indígenas do Brasil pode ser considerada recente. Trata-se da publicação do "Manual Indígena de Ecoturismo" no ano de 1997. Este documento representa o início da ação do Estado, dos órgãos não-governamentais e das populações indígenas no sentido da organização do turismo.

Assim, pretende-se neste estudo refletir sobre o turismo no território indígena Krahô, localizado no estado do Tocantins (Amazônia Legal Brasileira), utilizando-se as análises dos termos turismo, território, desterritorialização, reterritorialização e multiterritorialidades. Nesta lógica, entre os objetivos específicos da presente tese estão: 1) aprofundar o debate teórico e metodológico sobre o turismo, em particular, e sobre os novos segmentos turísticos que envolvem as populações autóctones; 2) identificar e delimitar os principais locais que podem ser visitados, destacando os pontos considerados proibidos para visitação pelos turistas no território indígena Krahô; 3 ) identificar a organização e gestão do turismo Krahô de acordo com a lógica das comunidades e das associações indígenas, isto é, tanto o turismo indígena quanto o turismo em territórios indígenas. 
A obra de Malinowski (1997) intitulada "Um diário no sentido estrito do termo" também foi utilizada nesta pesquisa, pois se trata de uma metodologia desenvolvida na área da etnologia e nos estudos etnográficos ${ }^{2}$ que contribuiu para a observação das comunidades e associações indígenas realizada durante a efetivação do trabalho de campo. Além do mais, a referida obra apresenta de forma sistemática alguns procedimentos importantes nas anotações das informações, as quais constituem material de registro para posterior análise.

A pesquisa-ação e a pesquisa participante foram utilizadas como ferramentas auxiliares na coleta de dados e informações em trabalho de campo, que contou com o auxílio das obras de Thiollent (1992) e de Brandão (1988), intituladas, respectivamente, "Metodologia da pesquisa-ação" e "Pesquisa-Participante". A pesquisa-ação passou a ser utilizada como método em diversas áreas do conhecimento, pois busca construir as possibilidades de mudanças e de transformações em diversos campos de atuação, oferecendo ferramentas para a realização de pesquisas nas Ciências Humanas e buscando rupturas na construção do conhecimento científico no sentido da pesquisa convencional.

Tenta-se construir uma proposta de trabalho utilizando-se os recursos teóricos e metodológicos da Ciência Geográfica, incluindo o uso da pesquisa-ação e da pesquisaparticipante. Tanto a pesquisa-ação quanto a pesquisa-participante possuem conteúdos ideológicos que muito contribuem para a realização do trabalho de campo, de modo que as duas trazem no seu bojo propostas de ações. Pode-se considerar que ambas possuem objetivos comuns e, ao mesmo tempo, buscam novas alternativas.

Como se sabe, o comprometimento com a teoria deve ser assegurado, o que não impede a adoção da pesquisa-ação e da pesquisa-participante na realização da pesquisa junto às populações indígenas. Uma vez que se realiza um trabalho de campo para a coleta de material de registro, objetivando-se a elaboração de uma proposta de investigação e de intervenção, não se pode descartar o envolvimento das comunidades das aldeias. Os povos indígenas Krahô estão distribuídos em dezoito (18) aldeias, o que evidencia a existência de várias facções, as quais são resultantes da estrutura social e política Krahô. Nesta lógica, deve-se firmar acordo com as comunidades indígenas e com as associações, perspectivando

2 "Ethnographie; E. Ethnography; F. Ethnographie; 1. Etnografia. Descrição dos diversos povos, do seu gênero de vida e das suas instituições. Rad. int.: Etnografi. (...) Etnologia: D. Etnologie; E. Ethonology; F. Ethonogie;

I. Etnologia. Estudo explicativo dos fenômenos descritos pela etnografia. Rad. int. Etnologi." (LALANDE, 1999, p. 350) 
construir relações de confianças entre pesquisador e participantes. $\mathrm{Na}$ atualidade, as comunidades e as associações indígenas esperam resultados das pesquisas que estão sendo desenvolvidas com o objetivo de tornarem-se fortalecidas.

A Kapey- União das Aldeias Krahô pode ser definida como a única associação que congrega todas as aldeias. Ao se propor o desenvolvimento do projeto "Turismo, Território e Modernidade: Um estudo da população indígena Krahô, Estado do Tocantins (Amazônia Legal Brasileira)", logicamente, pensou-se num trabalho que permitisse a reflexão analítica acerca do quadro em que se encontra a organização do turismo em territórios indígenas. A apresentação do projeto de pesquisa aconteceu na Escola Catxêkwy - Vivência Agroambienal, na sede da Kapey, no dia vinte e sete (27) de setembro de dois mil e quatro (2004). Estavam presentes os dezoito (18) Caciques e o Coordenador Geral da Kapey neste momento importante de apresentação do conteúdo da proposta de trabalho para as lideranças políticas das comunidades indígenas e da Kapey. Nesta lógica, estas articulações com as lideranças das comunidades indígenas e da Kapey foram necessárias para garantir a realização do trabalho de campo, como também para evitar conflitos com as facções políticas existentes na estrutura social e política dos Krahô.

O trabalho de campo no território indígena Krahô iniciou-se no primeiro semestre de 2004, mais especificamente nos meses de fevereiro, março, maio e julho, estendendo-se para os meses de agosto e setembro de 2004; junho e julho de 2005; e julho, agosto e setembro de 2006. Optou-se pelo desenvolvimento da proposta de trabalho com a participação das comunidades e associações indígenas, o que exigiu deslocamentos para as Aldeias e para a Kapey. Esta pode ser considerada a capital do Território Indígena Krahô. Os projetos que estão sendo desenvolvidos (Financiamento e Pesquisa) têm como responsável esta associação, a qual congrega todas as Aldeias Krahô.

Todo projeto de pesquisa que se pretende desenvolver no território indígena Krahô precisa ter a aprovação da Kapey. O presente estudo, então sob a forma de projeto, foi apresentado e, depois de aceito e ressalvado, seguiu-se para as comunidades indígenas. A opção por desenvolver a proposta de pesquisa em todas as comunidades indígenas tornou-se exigência por parte das lideranças políticas das comunidades e associações, a qual foi considerada do início ao final da pesquisa. 
O presente estudo encontra-se estruturado em três capítulos, além da Introdução e do item intitulado À guisa da conclusão.

O Capítulo 1, intitulado "O Turismo como um tema multidisciplinar", propõe uma discussão acerca dos termos turismo, território, desterritorialização, reterritorialização e multiterritorialidade. Este capítulo pode ser considerado uma parte importante da tese, pois apresenta um novo debate e traz uma contribuição para os segmentos turísticos relacionados ao fenômeno da globalização. Nele, pode-se perceber que a organização do turismo nacional e internacional voltada para os mega-projetos está subordinada à lógica da produção e da reprodução do capital. Sendo assim, nesta etapa do estudo pretende-se refletir sobre o termo território, adquirindo este um sentido dinâmico, uma vez que está supostamente sendo constituído em movimento. Vê-se, ainda, que o turismo se insere nos territórios-rede, utilizando-os com o intuito de consolidar o turismo internacional.

O Capítulo 02, intitulado "Turismo, território, modernidade e desenvolvimento local”, propõe uma análise teórica e metodológica acerca da relação entre o turismo, o território, a modernidade e o desenvolvimento local. Apresenta a realidade do turismo em territórios de populações autóctones e identifica novos segmentos turísticos, enfatizando o estudo, a análise e a compreensão do turismo indígena e do turismo em territórios indígenas.

Já o Capítulo 3, intitulado "Projetos Indígenas Krahô, desenvolvimento sócioespacial e a organização do turismo", apresenta uma análise do atual quadro em que se encontra a organização do turismo no território indígena Krahô. Nele, estuda-se e compreende-se os projetos Krahô que estão sendo desenvolvidos no que se refere aos eventos realizados no território desta população. Nesta lógica, são enfatizados os projetos aprovados por intermédio das ações da Kapey- União das Aldeias Krahô, sobretudo as Feiras Krahô de Sementes Tradicionais, importante evento que possibilita a elevação da auto-estima, a construção da identidade étnica, a divulgação dos artesanatos Krahô e a organização do turismo no território Krahô. 


\section{CAPÍTULO 1 - O TURISMO COMO UM TEMA DE PESQUISA INTERDISCIPLINAR}

Entre os objetivos deste capítulo se encontra a abordagem do estudo do turismo como um tema de pesquisa multidisciplinar, mote ao qual o artigo de Rodrigues (1999, p.1732) intitulado "Desafios para os estudiosos do turismo" traz significativas contribuições. Tal enfoque pode ser considerado necessário e deve ser atribuído ao turismo na sociedade contemporânea, de modo a construir uma análise seguindo a lógica de que

O turismo é, incontestavelmente, um fenômeno econômico, político, social e cultural dos mais expressivos das sociedades ditas pós-industriais. [...] Movimenta, em nível mundial, um enorme volume de pessoas e de capital, inscrevendo-se materialmente de forma cada vez mais significativa ao criar e recriar espaços diversificados. (RODRIGUES, 1999, p.17).

Ainda segundo esta autora, o turismo pode ser examinado em inúmeras modalidades, possuindo também diversas fases de organização, as quais podem ser encontradas sincronicamente num mesmo país, em escalas regionais ou locais. Vale acrescentar que o turismo tornou-se planetário, não poupando nenhum território, de modo que pode ser encontrado, de um lado, na sua forma espontânea e, de outro, seguindo a lógica do planejamento, ora estabelecendo vínculos de subordinação às políticas públicas, ora recebendo apoio da iniciativa privada. Nesse sentido,

Afinal o que é o turismo além de um fluxo de pessoas? O que é o turismo além de uma atividade econômica? É certamente um fenômeno complexo, designado por distintas expressões: uma instituição social, uma prática social, uma frente pioneira, um processo civilizatório, um sistema de valores, um estilo de vida - um produtor, consumidor e organizador de espaços -, uma "indústria", um comércio, uma rede imbricada e aprimorada de serviços. (RODRIGUES, 1999, p.17 e 18).

De acordo com as reflexões da autora, pode-se afirmar que o turismo atingiu uma fase de análise complexa, uma vez que extrapolou o diagrama de pesquisa dos clássicos setores de atividades econômicas, exigindo novos recursos teóricos e metodológicos. Entre os desafios encontrados pelos estudiosos do turismo está a análise deste setor nos sentidos 
econômico, político, cultural e ambiental, assim como uma observação integrada levando em conta os diferentes conceitos de território, desterritorialização e reterritorialização.

Sabemos, com certeza, que o turismo representa, hoje, uma das mais importantes formas de reprodução de capital e de captação de divisas no comércio internacional. É reconhecido como uma atividade que se presta muito à lavagem de dinheiro do narcotráfico, do jogo, da sonegação de impostos, da corrupção. (RODRIGUES, 1999, p.18).

Nessa perspectiva, o turismo possui um histórico que segue o percurso apontado pelas mega-empresas de capitais transnacionais, as quais buscam estratégias de expansão e de domínio em diversas localidades em nível planetário. Por um lado, "No período atual são os grandes ecossistemas, até então preservados do mundo tropical, em particular dos continentes africano e latino-americano - espaços de reserva de valor -, que agora são chamados a entrar em cena" (RODRIGUES, 1999, p.18). Por outro, se pode verificar que várias territorialidades da América Latina estão sendo incluídas nos roteiros de turismo com um forte cunho ecológico.

A tendência de expansão do turismo na Amazônia Legal Brasileira, por exemplo, pode ser compreendida a partir de sua divulgação em dois contextos: um referente à exposição da região aos crimes ambientais (desmatamento desordenado e mineração descontrolada); e outro que evidencia a potencialidade paisagística e as fortes manifestações culturais locais e regionais. A partir destes dois contextos, a Amazônia tornou-se bastante divulgada no cenário internacional. Segundo Rodrigues (1999, p.19), "Hotéis aparentemente rústicos - os lodges - se multiplicaram pela Amazônia. O primeiro foi inaugurado em 1981. Atualmente ultrapassa uma dezena, com cerca de quatrocentos leitos, com boa taxa de ocupação anual (60\%)".

Comumente, considera-se que o turismo internacional segue a lógica da procura de lugares em que o visitante pode buscar a aventura, o autêntico e o inusitado, atributos que são encontrados na região Amazônica - na sua expressão identitária. Nesta lógica, de um lado, o lugar pode ser considerado como um fragmento do global, contrapondo-se, por isso, a este, e, de outro, o global se alimenta do fragmento e vice-versa. Destarte, o turismo pode ser identificado entre diferentes lugares e territórios e mencionado como importante constituinte de multiterritorialidades. 
Os resorts são os melhores exemplos de que os turistas buscam a reterritorialização, já que neles sentem-se territorializados num território construído de forma artificial e, concomitantemente, reterritorializam-se ao se identificarem com o lugar e nele permanecerem por uma temporada de férias. As inovações tecnológicas contribuem para esta reterritorialização no sentido de permitirem a integração entre as sociedades por meio dos recursos tecnológicos, entre os quais a internet. Esta, por sua vez, permite a identificação de uma variedade de opções de locais turísticos ao redor do mundo e, ainda, pode possibilitar até mesmo a efetivação das reservas nas redes hoteleiras globais. Sendo assim, pode-se afirmar que foram constituídos territórios-rede de turismo.

Esta é uma questão que será bastante discutida neste capítulo. Portanto, torna-se fundamental realizar uma análise do turismo, incluindo os termos território, desterritorialização, reterritorialização, hibridismo cultural, modernidade e pós-modernidade.

De certa forma, o turismo tem seus estudos mais aprofundados na sua formaconteúdo multidisciplinar, pois "Reconhecemos que os estudos do turismo já constituem um conjunto sistematizado de conhecimentos nos campos da Geografia, da Economia, da Sociologia, da Antropologia, da Administração, da comunicação, da psicologia, só para citar alguns." (RODRIGUES, 1999, p.19-20). No dizer da autora, a prática da transdisciplinaridade caminha para o conhecimento total e a disciplinarização do saber empobrece a apreensão da totalidade.

Nesta lógica, a ruptura com os paradigmas clássicos positivistas permitiu a busca de novas orientações teóricas e metodológicas, possibilitando a construção de novos conceitos. Assim, o estudo do turismo continua sendo considerado multidisciplinar e, por conseguinte, não se restringe a nenhuma ciência autônoma. "Mesmo porque, no período de revisão dos paradigmas em que se encontram as ciências, hoje, é muito difícil determinar tecnicamente o grau de especificidade com base no qual se produz uma qualidade epistemológica nova." (RODRIGUES, 1999, p.22).

Vale destacar, ainda, a importância do material bibliográfico na área da Geografia, cujo conteúdo permite o estabelecimento da linguagem geográfica no contexto das demais linguagens das Ciências Humanas sobre o turismo. Nesse sentido, os referenciais teóricos e metodológicos da Geografia, em específico, sobre os usos dos diferentes conceitos de território podem contribuir para a análise e compreensão do turismo. 


\subsection{OS USOS DOS DIFERENTES CONCEITOS DE TERRITÓRIO}

Atualmente, o espaço e o tempo estão sendo analisados na lógica da globalização a partir de diversos enfoques. As reflexões perpassam pela idéia de proximidade e de distância, pela fragilização das fronteiras e por uma possível crise da territorialidade dominante. Nesta perspectiva, o Estado nação e o território continuam tendo relevância como objetos de estudo da Geografia, de modo que aumenta a complexidade das análises.

Os usos dos diferentes conceitos de "território" permitiram a elaboração de proposições para este termo, incluindo outros novos, como, por exemplo, desterritorialização e reterritorialização. Em sua obra intitulada "O mito da desterritorialização", Haesbaert (2004) afirma que o termo desterritorialização está presente nas Ciências Sociais desde os anos 70, sobretudo entre os filósofos Gilles Deleuze e Félix Guatarri, embora não esteja em meio aos vocábulos dos grandes dicionários.

Ainda segundo Haesbaert (2004, p.21), "Na Geografia, o primeiro registro deste verbete, de nossa autoria, é extremamente recente, tendo sido publicado no 'Dictionnaire de la Géographie et de l'espace des sociétés em 2003' (Lévy e Lussault)". A inserção recente deste verbete no referido dicionário contribui para o aprofundamento das reflexões no contexto da Geografia, assim como para o registro de uma referência para o termo desterritorialização, demonstrando os cuidados a serem tomados com relação aos diferentes usos conceituais que estão sendo realizados nas Ciências Humanas.

Nesse sentido,

No Oxford English Dictionary consta apenas o termo territorialização, derivado de territorializar, que significa tornar territorial, situar em bases territoriais, ou ainda associar a um território ou distrito particular. O mais interessante é observar as citações assinaladas, uma de 1848, comentando que 'recentemente o papa territorializou sua autoridade numa grande área', outra de 1897 sobre a 'territorialização do serviço militar' (e do exército), e uma de 1899 sobre a 'territorialização das ferrovias' (p.819). Pode-se perceber a estreita ligação com processos político-institucionais de construção de territórios, viabilizando, pelo território, interesses de ordem político-cultural (Igreja), político-militar (Exército) e político-econômica (redes técnicas). (HAESBAERT, 2004, p.21). 
Conforme o autor, o termo desterritorialização não pode ser considerado como argumento inédito, já que nas obras de Marx intituladas "O Capital" e "Manifesto Comunista" vinha sendo tratado como uma questão ocorrente no sistema econômico capitalista, principalmente no momento de sua consolidação, no século XIX. O pensamento marxiano manifesta preocupações com relação à desterritorialização capitalista, por exemplo, de uma situação de camponês expropriado para a situação de trabalhador livre, de morador da área rural para morador urbano. Além do mais, a desterritorialização possui uma estreita relação com as atribuições do capitalismo e da modernidade. Por isso, as análises deverão caminhar em dois sentidos, isto é, a partir, de um lado, dos grupos hegemônicos (incluídos) e, de outro, dos grupos subordinados (excluídos) da globalização.

No livro de Debord (1997) intitulado "A sociedade do espetáculo", em especial no capítulo VII, pode-se verificar uma análise crítica acerca da produção capitalista e de seus reflexos no planejamento do espaço. Haesbaert (2004) menciona que Debord percebeu os efeitos desterritorializadores/globalizadores do capitalismo, destacando que:

A produção capitalista unificou o espaço, que já não é limitado por sociedades externas. Essa unificação é ao mesmo tempo um processo extensivo e intensivo de banalização. A acumulação das mercadorias produzidas em série para o espaço abstrato do mercado, assim como devia romper as barreiras regionais e legais e todas as restrições corporativas da Idade Média que mantinham a qualidade da produção artesanal, devia também dissolver a autonomia e a qualidade dos lugares. Essa força de homogeneização é a artilharia pesada que fez cair todas as muralhas da China. (DEBORD, 1997, p.111).

De acordo com as reflexões de Debord (1997), o espaço está sendo transformado porque pode ser considerado "o espaço livre da mercadoria". Uma das características essenciais da sociedade contemporânea é a tentativa de suprimir a distância geográfica, recolhendo interiormente a distância como separação espetacular.

Subproduto da circulação das mercadorias, o turismo, circulação humana considerada como consumo, resume-se fundamentalmente no lazer de ir ver o que se tornou banal. $\mathrm{O}$ planejamento econômico da freqüência de lugares diferentes já é em si a garantia de sua equivalência. A mesma modernização que retirou da viagem o tempo, lhe retirou também a realidade do espaço. (DEBORD, 1997, p.112). 
A sociedade contemporânea revela novas formas de agir sobre o território, de modo que o capitalismo desenvolveu sua lógica de dominação absoluta, refazendo a totalidade do espaço como "seu próprio cenário". Logicamente, com o urbanismo o capitalismo confirmou sua necessidade de produção e reprodução do capital, ficando mais evidente a coexistência do espaço e a sucessão do tempo.

Haesbaert (2004) evidencia a importância de uma análise mais rigorosa dos termos território e desterritorialização, uma vez que o uso de um não elimina o outro; pelo contrário, o uso de um termo-conceito de território induz à construção de termos-conceitos específícos e que não podem ser empregados em todas as situações. Neste aspecto, os diferentes usos dos conceitos de território permitem a construção de distintas concepções de desterritorialização, assim como as análises, desde as mais conservadoras até as progressistas. É, certamente, das nuances entre as diferentes concepções teóricas e metodológicas que serão construídas as argumentações sobre os usos dos conceitos de território.

\subsection{ANÁLISE DO CONCEITO DE TERRITÓRIO E O O USO DO TERMO DESTERRITORIALIZAÇÃO}

As investigações sobre o turismo parecem perpassar pelos estudos dos conceitosteóricos do território, da desterritorialização e da modernidade. Tais conceituações estão, evidentemente, imbricadas, mas sua matriz principal é o território. A partir da compreensão do território pode-se buscar as interpretações do turismo e da modernidade.

O território pode ser definido nos sentidos político, econômico, cultural e natural. Existe, ainda, a possibilidade de se construir uma análise interativa de território. Para isto, torna-se fundamental problematizar o termo território para se compreender o termo desterritorialização; ou seja, faz-se necessário esclarecer a instância do território que está em discussão.

Haesbaert (2004, p.35) refere-se às diferentes concepções de território que poderão ser usadas para definir desterritorialização da seguinte maneira:

Dependendo da concepção de território muda, conseqüentemente, a nossa definição de desterritorialização. Assim, podemos perceber a enorme polissemia que acompanha a sua utilização entre os diversos autores que a discutem. Como já enfatizamos, muitos sequer 
deixam explícita a noção de território com que estão lidando, cabendo a nós deduzí-la. Daí a importância de esclarecermos, de início, as principais linhas teórico-conceituais em que a expressão é ou pode ser utilizada, sem em hipótese alguma pretender impor conceituação à problemática, mas mostrando sempre a diferenciação e transformação dos conceitos em função das questões priorizadas.

Deve-se, portanto, fazer o esforço de reunir as possibilidades do diálogo interdisciplinar para se aprofundar os conceitos-teóricos sobre território e desterritorialização e para se compreender, inclusive, a relação entre território, desterritorialização e modernidade. Estas matrizes teóricas, uma vez aprofundadas, podem contribuir para a análise do turismo. Dessa maneira, pode-se asseverar que o turismo está inserido na lógica do território, da desterritorialização e da reterritorialização.

Cabe destacar também que os conceitos de território e de territorialidade estão, para a Geografia, relacionados ao espaço geográfico humano. Por isso, as noções de território são ampliadas para as dimensões política, cultural e econômica. Na medida em que se deseja avançar nas concepções de território deve-se levar em conta os entrecruzamentos de proposições teóricas. Haesbaert (2004, p.37-80) propõe algumas interpretações para o conceito de território, as quais são, a seguir, apresentadas numa síntese:

a) Território nas perspectivas materialistas: o território do ponto de vista da existência, com uma proposta de análise ontológica, pode ser interpretado tanto na realidade físico-material quanto na realidade ideal.

b) Concepções naturalistas: esta concepção foi a mais propagada de todas as interpretações, sendo o território natural tido como referência no comportamento dos animais ou no comportamento natural dos homens. Daí a relação sociedade-natureza. Nos estudos etnográficos (Sociologia e Antropologia) podem ser encontrados inúmeros trabalhos com concepções naturalistas de território.

c) Concep̧̧ões de base econômica: o território recebe uma conotação de fonte de recursos, de apropriação da natureza, de controle e de uso, propiciando interpretações, principalmente, nos estudos etnográficos das sociedades indígenas, além de outras sociedades não-indígenas que se enquadram na tipologia de sociedades tradicionais ou em processo de (des)tradicionalização.

d) A tradição jurídico-política de território: do conjunto dos conceitos pode ser o de uso mais tradicional. Faz a associação entre o território e os fundamentos materiais 
do Estado, seguindo a proposição do clássico geógrafo alemão Friedrich Ratzel. Os estados foram estruturados com base na idéia de soberania.

e) Território nas perspectivas idealistas: o território também pode ser interpretado a partir do uso dos seus recursos e dos diferentes grupos étnicos (tratando-se dos povos indígenas que são diferentes entre si e diferentes dos demais povos não-indígenas) que dele usufruem.

f) Território numa perspectiva integradora: proposta de investigação teórica e metodológica que precisa ser aprofundada. Sobre seu conceito, Haesbaert (2004, p.74) afirma:

Encontramos aqui um outro debate muito relevante: aquele que envolve a leitura de território como um espaço que não pode ser considerado nem estritamente natural, nem unicamente político, econômico ou cultural. Território só poderia ser concebido através de uma perspectiva integradora entre as diferentes dimensões sociais (e da sociedade com a própria natureza).

O problema foi colocado. Agora, o desafio se restringe às possibilidades de avanços nas concepções do processo de desterritorialização, noção que tem sido construída a partir do conceito de hibridismo cultural, tendo como referências as noções de territórios setoriais ou fragmentados e, por último, uma identificação do termo reterritorialização como significado de resistência.

\subsection{TERRITORIALIZAÇÃO, DESTERRITORIALIZAÇÃO E RETERRITORIALIZAÇÃO}

De acordo com Haesbaert (2004), estes termos podem ser entendidos a partir da obra dos filósofos franceses Gilles Deleuze e Félix Guattari. Nesse sentido, Haesbaert (2004, p.99100) registra que: "Embora tenhamos dúvidas se foram eles, efetivamente, os 'inventores' do termo, é fato que a maior ênfase ao território como processo, com o permanente 'tornar-se' e desfazer-se, foi dada por eles." 3

\footnotetext{
${ }^{3}$ Nota do próprio autor: "Deleuze, em Dialogues (Deleuze e Parnet, 1987: 134), afirma que foi Félix Guattari quem inventou as palavras territorialização e desterritorialização. Segundo Bogue (1999), Guattari começou a fazer uso dos conceitos de des-re-territorialização em discussões de psicologia de grupo, a propósito da identificação das massas com um líder carismático, 'uma territorialização
} 
Sabe-se, ainda, que estes termos começaram a ser utilizados de diferentes formas nas Ciências Humanas como uma tentativa de se compreender a complexidade da sociedade contemporânea. Sendo assim,

Devemos antes de tudo pensar a territorialização e a desterritorialização como processos concomitantes, fundamentais para compreender as práticas humanas. Não são poucos, contudo, os mal-entendidos na tradução dos sentidos em que a expressão é utilizada. Nosso objetivo primeiro é, assim, elucidar um pouco mais a concepção de desreterritorialização tal como eles nos apresentam, cientes do grande potencial que ela nos reserva para novas explorações no campo da Geografia. (HAESBAERT, 2004, p.101).

Deve-se, no entanto, destacar que:

Nem todos os indivíduos vivenciam os três tipos de linhas, as da segmentaridade rígida ou molar (segmentos claramente definidos, ligados à família, à escola, ao trabalho), as da segmentaridade flexível ou molecular (reino do "devir" e da desterritorialização relativa) e as linhas de fuga, consideradas primordiais, pelo poder de transformação que carregam - a "desterritorialização absoluta" [...]. (HAESBAERT, 2004, p.115).

A razão que leva o autor a fazer a análise da obra de Deleuze e Guattari na Geografia pode ser compreendida a partir das possibilidades do aprofundamento de temáticas polêmicas em que os geógrafos poderão se debruçar. Se, em geral, a organização da sociedade contemporânea é pensada utilizando-se a palavra rizoma, os enfoques estão buscando analisar os encontros, os acontecimentos e os agenciamentos.

Hardt e Negri (2002, p.47) afirmam que "se nessa altura tivéssemos de perguntar a Foucault quem ou o que impele o sistema, ou melhor, o que é o 'bios', sua resposta seria inefável, ou não haveria reposta. O que Foucault não entende, finalmente, é a dinâmica real da produção na sociedade biopolítica". ${ }^{4} \mathrm{O}$ ponto de discórdia entre Foucault e Deleuze pode

imaginária, uma corporificação de grupo fantasmática que encarna subjetividade', e da tendência do capitalismo como força decodificadora e desterritorializadora (F. Guattari em Psychanalyse e transversalité [1972:164; apud Bogue, 1999:86].” (HAESBAERT, 2004, p.100)

${ }^{4}$ Nota dos próprios autores: "Quando Deleuze formula suas diferenças metodológicas com Foucault em uma carta particular escrita em 1977, o principal ponto de discórdia é, no fim das contas, justamente uma questão de produção. Deleuze prefere o termo 'desejo' ao 'prazer' de Foucault, explica, porque desejo expressa a dinâmica ativa da produção de realidade social enquanto prazer é meramente inerte e reativo: 'Prazer interrompe a positividade do desejo e a constituição do seu plano de imanência'. Ver Gilles Deleuze, 'Désir et plaisir', Magazine Littéraire, no 325 (outubro 1994), 5965; citação p.64.” (HARDT e NEGRI, 2002, p. 445) 
contribuir para o entendimento da construção das reflexões sobre território. Deleuze prefere utilizar o termo desejo (dinâmico) ao invés de prazer (interrompe o desejo).

Tal como o poder na abordagem de Foucault, que é produtivo (e não só repressivo) e constituinte de toda relação social, organizado em torno de dispositivos como a "máquina" panóptica, em Deleuze e Guattari trata-se do desejo, também agenciado por "máquinas" e tendo um sentido produtivo, construtivo. (HAESBAERT, 2004, p.118).

Esta abordagem permite inserir a idéia de movimento, ampliando as noções de territorialização e de desterritorialização. "Trata-se na verdade de uma vasta mudança de escala: iniciando com território etológico ou animal (1), passamos ao território psicológico ou subjetivo (2) e daí ao território sociológico (3) e ao território geográfico (4) (que inclui a relação sociedade-natureza)." (HAESBAERT, 2004, p.121).

A noção de território, para Deleuze e Guattari, está articulada com o termo agenciamento, e é nesta lógica de território-agenciamento que é possível situar os processos de territorialização e desterritorialização. Desta maneira, todo agenciamento pode ser considerado territorial. E, certamente, se tudo pode ser agenciado, tudo pode ser também desterritorializado e reterritorializado.

É evidente que a idéia de movimento tornou-se comum para os dois tipos de agenciamentos, já que um território se constitui e comporta dentro de si vetores de desterritorialização e de reterritorialização. Pode-se afirmar que desterritorialização refere-se ao movimento de abandono do território e que reterritorialização trata-se de um movimento de construção do território.

As figuras do sedentário, do migrante e do nômade (desterritorializado) contribuem para o entendimento do movimento de construção do território. Destarte, a figura do nômade está no centro das preocupações de Deleuze e Guattari e são elementares para se compreender os teoremas em que são estabelecidas as distinções de desterritorialização.

Com relação aos três (03) teoremas da desterritorialização propostos por Deleuze e Guattari, Haesbaert (2004, p.127-128) assim os sintetiza: 
Primeiro: Trata-se do movimento concomitante e indissociável entre desterritorialização e reterritorialização, que é a proposição maquínica;

Segundo: Relação entre desterritorialização e velocidade;

Terceiro: Relação de intensidade dentro do processo de des-reterritorialização. O terceiro teorema estabelece dois tipos de desterritorialização, isto é, desterritorialização relativa (abandono de territórios criados e reterritorialização) e desterritorialização absoluta (dupla dimensão dos eventos).

Como se sabe, para que o pensamento possa existir faz-se necessário um solo, um meio, ou seja, a própria terra. Assim, a terra é a grande desterritorializada, sendo que sua reterritorialização pode ocorrer de duas maneiras: na construção dos territórios sociais e no plano de imanência de um pensamento.

O Estado e o capital agem no sentido da desterritorialização e da sobrecodificação ${ }^{5}$. Por exemplo, há, de um lado, as sociedades capitalistas constituindo processos de desterritorialização e, de outro, as sociedades pré-capitalistas efetivamente territoriais. "São identificados três grandes tipos de 'maquinas sociais': a máquina territorial primitiva, a máquina despótica e a máquina capitalista." (HAESBAERT, 2004, p.134). Sendo consideradas separadamente, cada uma destas máquinas tem as suas singularidades e quando presente de forma dominante numa determinada sociedade permite interpretações e análises específicas.

Nas comunidades tradicionais a terra é concebida como terra-divindade, e nas sociedades estatais torna-se terra-estado, sendo que o Estado e o capital podem ser considerados os desterritorializadores das sociedades pré-capitalistas. Nesse sentido, o Estado pode ser compreendido como desterritorializador, de modo que o primeiro teorema proposto por Deleuze e Guattari confirma a sua validade de análise. Nesta lógica, fica evidente a maneira como o território é entendido.

Deleuze e Guattari propõem outras interpretações sobre a ação do Estado na construção da territorialidade. Segundo esses autores, o Estado pode ser concebido como

\footnotetext{
5 “A noção de sobrecodificação está associada à noção de código, que 'é empregada numa acepção bem ampla: ela pode dizer respeito tanto aos sistemas semióticos quanto aos fluxos sociais e aos fluxos materiais. O termo 'sobrecodificação' corresponde a uma codificação de segundo grau' (Guattari e Rolnik, 1986: 317-318).” (HAESBAERT, 2004, p.134).
} 
territorializador, desterritorializador (proposição maquínica) e reterritorializador (sobrecodificação). Isto é, em qualquer momento podem ocorrer novos agenciamentos maquínicos de corpos e agenciamentos coletivos de enunciação.

Tanto os processos de desterritorialização quanto os de reterritorialização podem ser considerados distintos. Mas o que é comum na sociedade contemporânea é o constante movimento de desterritorialização e de reterritorialização. No dizer dos autores, estamos sempre passando de um território para outro, abandonando territórios e fundando novos. Por exemplo, o operário da fábrica de automóveis e o bóia-fria morador da periferia urbana estão entre os atores sociais em constantes movimentos de desterritorialização e de reterritorialização.

O consumo de produtos e de serviços pode ser responsável pela aceleração do tempo e pela compressão do espaço. Neste aspecto, Harvey (2000, p.258) aponta duas tendências: uma relacionada ao consumo de bens e outra que se refere ao consumo de serviços, de modo que:

Dentre os muitos desenvolvimentos da arena do consumo, dois tem particular importância. A mobilização da moda em mercados de massa (em oposição a mercados de elite) forneceu um meio de acelerar o ritmo do consumo não somente em termos de roupas, ornamentos e decoração, mas também numa ampla gama de estilos de vida e atividades de recreação (hábitos de lazer e de esporte, estilo de música pop, videocassetes e jogos infantis etc.). Uma segunda tendência foi a passagem do consumo de bens para o consumo de serviços - não apenas serviços pessoais, comerciais, educacionais e de saúde, como também de diversão, de espetáculos, eventos e distrações. "O tempo de vida" desses serviços (uma visita a um museu, ir a um concerto de rock ou ao cinema, assistir a palestras ou freqüentar clubes), embora difícil de estimar, é bem menor do que o de um automóvel ou de uma máquina de lavar. (HARVEY, 2000, p.258).

De acordo com as reflexões do autor, esta lógica de consumo provoca o fornecimento de serviços bastante efêmeros. Entre tais serviços pode-se citar os diversos segmentos de turismo que passaram a ser oferecidos a partir da Segunda Guerra Mundial. Entretanto, tanto o tempo quanto o espaço continuam como uma categoria de análise única (tempo-espaço), inseparável, o que sugere a introdução de outras formas de apreciação.

Os autores que relacionam desespacialização com desterritorialização e desterritorialização com compressão e/ou desencaixe fazem uma leitura simplificada da desterritorialização. Esta possui uma complexidade que ultrapassa a idéia de que seja apenas o fim das distâncias, concepção que confunde territorialidade e espacialidade e que considera o 
espaço na perspectiva dos processos de compressão tempo-espaço. Logicamente, realizar uma reflexão sobre os processos de territorialização, de desterritorialização e de reterritorialização num sentido mais amplo, associando a noção de múltiplos territórios (multiterritorialidade) na chamada pós-modernidade, permite aprofundar e obter nova experiência e concepção de espaço-tempo.

O termo desterritorialização pode ser analisado em três (03) dimensões sociais, sendo que estas estão associadas a diferentes conceitos de território: a econômica, a política e a simbólica ou cultural. A dimensão social econômica compreende três (03) perspectivas de desterritorialização: 1) a desterritorialização como sinônimo de globalização; 2) a desterritorialização como sinônimo de deslocalização; e 3) a desterritorialização como um processo vinculado a um setor específico da economia globalizada, como, por exemplo, o setor financeiro, entre outros.

Como se sabe, o termo desterritorialização possui um vínculo com a expressão globalização, pois é neste momento histórico em que a vida social e cultural nos diversos países do mundo torna-se cada vez mais afetada por influências internacionais que a dinâmica capitalista mostra-se acelerada. É por este motivo que se pode encontrar um diversificado material de registro fazendo referências e associações entre globalização e desterritorialização. Esta análise torna-se possível levando-se em consideração a acumulação primitiva de capital e os impactos sociais que foram criados ao longo do modo de produção capitalista.

De certa maneira,

O capital, diferentemente, opera no plano da imanência, através de relés e redes de relações de dominação, sem recorrer a um centro transcendente de poder. Ele tende historicamente a destruir tradicionais fronteiras sociais, ampliando-se através de territórios e envolvendo sempre novas populações dentro de seus processos. O capital funciona, segundo a terminologia de Deleuze e Guattari, mediante uma decodificação generalizada de fluxos, uma maciça desterritorialização, e mediante conjunções desses fluxos desterritorializados e decodificados. ${ }^{6}$ (HARDT e NEGRI, 2002, p.348).

\footnotetext{
${ }^{6}$ Nota dos próprios autores: "Os textos que estabelecem os termos de uma vasta literatura de debates sobre a periodização das fases da produção moderna são Daniel Bell, Coming of Post-industrial Society (Nova York: Basic Books, 1973); e Alain Touraine, Post-industrial Society, tradução de Leonard Mayhew (Nova York: Random House, 1971).” (HARDT e NEGRI, 2002, p. 482)
} 
De acordo com as reflexões dos autores, o capital pode ser analisado como o responsável e provocador do processo de desterritorialização. Assim sendo,

Pode-se entender o funcionamento do capital como desterritorializante e imanente em três aspectos primários que o próprio Marx analisou. Em primeiro lugar, nos processos de acumulação primitiva, o capital separa populações de territórios especificamente codificados e as põe em marcha. Ele desobstrui os Estados e cria um proletariado "livre". Culturas e organizações sociais tradicionais são destruídas na marcha incansável do capital pelo mundo afora para criar as redes e os caminhos de um único sistema cultural e econômico de produção e circulação. Em segundo lugar, o capital reúne todas as formas de valor num só plano comum e os vincula por intermédio do dinheiro, seu equivalente geral. O capital tende a reduzir todas as formas previamente estabelecidas de status, título e privilégio ao nível do nexo monetário, isto é, a termos quantitativos e econômicos comensuráveis. Em terceiro lugar, as leis pelas quais o capital funciona não são leis fixas e separadas que pairam acima de tudo e dirijam do alto as operações do capital, mas são historicamente leis variáveis imanentes ao próprio funcionamento do capital: as leis de taxas de lucro, de taxas de exploração, de realização de mais-valia, e assim por diante. (HARDT e NEGRI, 2002, p.348).

O capital atua como um mecanismo de controle social, já que é possível que ocorra o desenvolvimento social do capital. Aliás, este pode ser considerado como um mecanismo de soberania moderna, estabelecendo que o capital é o responsável por impor uma ordem limitada e segmentada, rompendo cada vez mais com as fronteiras, os limites e as forças locais, para atuar na acumulação de capital em nível mundial. Nessa perspectiva, a proposição que coloca a desterritorialização como a principal causadora do processo de globalização e eliminação das fronteiras pode ser compreendida como um projeto neoliberal.

Essa propagação do termo desterritorialização vinculado ao conceito tradicional de território pode ser compreendida a partir da relação entre espaço e soberania estatal (poder). Nesta lógica, o Estado nação, ao mesmo tempo em que é visto com um agente territorializador, é, ainda, nas concepções de Deleuze e Guattari, analisado como um agente desterritorializador.

O Estado tem, entre suas atribuições, o dever de organizar a sociedade e a produção, e por isso pode ser considerado como responsável pela prática da desterritorialização. Por exemplo, as comunidades pré-capitalistas e as populações indígenas, que antes se encontravam inseridas no princípio de imanência, foram submetidas ao princípio da transcendência, de modo que ocorreu um processo de desterritorialização motivado pelo 
Estado, que inseriu novas bases de organização do socius. Deleuze e Guattari, dentre outros autores, reafirmam os propósitos do Estado nação como um agente desterritorializador.

De certa forma, pode-se perceber a existência de três movimentos: o movimento territorializador, o movimento desterritorializador e, por último, o movimento reterritorializador. O Estado atua como um agente reterritorializador quando busca implantar mecanismos de controle de fluxos de todos os tipos (populações, mercadorias, dinheiro, capital etc.). Logicamente, o Estado pode ser compreendido como um agente que possui práticas de territorialização, de desterritorialização e de reterritorialização e desreterritorialização, de modo que destrói territorialidades e cria outras novas, no intuito de estabelecer um padrão político-administrativo mais universalizante.

Já no que se refere à dimensão cultural, vale afirmar que a desterritorialização pode ser analisada a partir desta perspectiva, uma vez que as atividades econômicas e políticas são consideradas como carregadas de sentidos e símbolos. Como se sabe, os autores que utilizam as abordagens culturalistas acreditam que a dimensão cultural precede a dimensão política dos territórios. Sendo assim, pode-se considerar que a desterritorialização cultural possui também um movimento de reterritorialização.

Termos como desprendimento cultural, desvinculação cultural, culturas desterritorializadas e hibridismo cultural estão sendo utilizados nos estudos da cultura e do território e até mesmo como quase-sinônimos de desterritorialização. Já a expressão reterritorialização pode ser usada na perspectiva de conquista de novos territórios, cabendo a sua utilização, por exemplo, à situação em que antigos grupos étnicos reinventam as suas tradições dentro de determinados contextos históricos e geográficos, resultando em conquistas territoriais.

Por exemplo, a população indígena Krahô/Canela, no estado do Tocantins, reivindica o seu território. Trata-se de uma etnia do Grupo Macro Jê, Grupo Étnico Timbira e Língua Timbira, que, no entanto, não fala mais a Língua Timbira e nem o Dialeto Krahô/Canela, de modo que é evidente a necessidade da demarcação do Território Indígena Mata Alagada. Vale destacar, ainda, o caso específico da população indígena Krikati, no estado do Maranhão, que conseguiu conquistar uma área próxima ao Território Indígena Krikati. Quanto ao processo de demarcação deste tipo de território no Brasil, parece ser uma prática comum que uma parte de determinada área fique para ser demarcada posteriormente, o que acaba sendo concretizado apenas depois de lutas e campanhas. 
Portanto, mostra-se relevante a análise do território e da desterritorialização no contexto da dimensão cultural, já que o tema envolve diferenças culturais e níveis de interação cultural. Nesta lógica, podem existir diferentes territórios culturais, como territórios culturalmente mais fechados (territorialização interna e desterritorialização externa/excluídos) e territórios culturalmente mais híbridos (diálogo intercultural). Comumente, há um conjunto de sociedades e espaços que vivem mais intensamente o hibridismo, isto é, em que as mesclas culturais são mais intensas.

O processo de hibridização das culturas, por sua vez, permite levantar alguns elementos e algumas questões sobre a desterritorialização e a reterritorialização. O aprofundamento deste debate pode avançar nas perspectivas da hibridização das culturas e da mobilidade (migrações regionais, nacionais e internacionais), análises consideradas, neste estudo, relevantes para se identificar as atuais tendências e segmentos do turismo contemporâneo.

\subsection{HIBRIDIZAÇÃO DAS CULTURAS, MOBILIDADE E I-MOBILIDADE SOCIAL}

Os termos desterritorialização e reterritorialização estão sendo usados para fazer referência à hibridização das culturas e à mobilidade das pessoas na sociedade contemporânea. Assim, vêm adquirindo um sentido cada vez mais polissêmico, podendo indicar uma variedade de significados que perpassam pelos sentidos econômico, político e cultural.

O debate envolvendo tais termos que mais apresenta complexidade está relacionado à diminuição do controle das fronteiras nacionais, devido ao aumento da dinâmica, da fluidez e da mobilidade de pessoas, bens materiais, capitais e informações. Por conseguinte, as temáticas intituladas nomadismo, migração e turismo podem ser consideradas relevantes para a construção da discussão sobre a desterritorialização e a hibridização das culturas, de modo que se deve acrescentar a essa questão a mobilidade e a i-mobilidade humana.

Destaca-se, de certa maneira, que a territorialização pode ocorrer e ser construída no movimento, assim como a desterritorialização pode estar associada à i-mobilidade. Nesse sentido, parece que foi desenvolvida toda uma cultura das viagens, representando uma crescente mobilidade das pessoas e uma diversidade das formas de participação de sujeitos 
e/ou atores. Haesbaert (2004) propõe alguns exemplos, destacando o nômade, o vagabundo e o migrante. Enquanto o nômade e o vagabundo enfrentam uma forte carga cultural de marginalidade e/ou subversão, o migrante é considerado aquele que busca integração.

O nomadismo apresenta atribuições e características consideradas pós-modernas, tendo, ainda, certo valor libertário e criador de desterritorialização. No entanto, vale destacar que o território pode ser definido como repetição do movimento, isto é, o nômade num movimento repetitivo e sob controle. Já o migrante não pode ser analisado e compreendido apenas como um sujeito desterritorializado. Entre as atribuições e peculiaridades do processo de migração, se pode mencionar que, em primeiro lugar, de acordo com o teorema deleuziano, não há desterritorialização sem territorialização e, em segundo lugar, o migrante pode ser compreendido como uma categoria complexa, devendo-se considerar os vários tipos de migrantes e os vínculos com os seus grupos sociais de movimentos migratórios.

As migrações podem ser caracterizadas como econômicas, políticas, culturais e ambientais. Cada tipo de migração remete a um tipo de desterritorialização, podendo esta também ser de natureza econômica, política, cultural ou ambiental. É a figura do migrante que permite a definição do tipo de desterritorialização que está ocorrendo. O turista, por sua vez, pode ser analisado de forma semelhante a do migrante, já que também está inserido na lógica da territorialização, da desterritorialização e da reterritorialização. A única atribuição comum entre o turista, o nômade, o vagabundo e o migrante é a mobilidade.

É evidente que a sociedade contemporânea atribui um valor estimável ao movimento, isto é, às diversas possibilidades de deslocamento, às perspectivas de mudanças, às aventuras e ao acesso e acionamento/recriação de diferentes territórios. Contudo, a mobilidade espacial não está necessariamente associada à mobilidade social. De certa maneira, os debates sobre desterritorialização e mobilidade e sobre desterritorialização e i-mobilidade podem ser assim sintetizados: mobilidade não significa desterritorialização e i-mobilidade não significa territorialização.

Outra argumentação aparece nas análises acerca das viagens realizadas pelos homens de negócios globalizados, que também são chamados de turistas. Nas suas viagens, pode-se dizer que acontece um processo de reterritorialização. Em contrapartida, os miseráveis, os excluídos e os reclusos em seus territórios estão dentro da lógica da i-mobilidade e podem ser considerados desterritorializados. Os indivíduos tidos como mais globalizados, entretanto, sofrem determinadas restrições com relação aos lugares que podem e aos que devem visitar. 
Por isso as reuniões acontecem nos grandes centros de negócios internacionais ou em resorts sofisticados (territórios-rede próprios), também utilizados pelos turistas que valorizam o turismo global.

Já os indivíduos que se enquadram nas situações em que são utilizados os termos desterritorialização, mobilidade e reclusão são os escravos africanos na América, os presidiários, os internos nos manicômios, os habitantes do gueto de Varsóvia, recriado pelo nazismo para a reclusão e posterior dizimação dos judeus poloneses, os que vivem em campos de concentração, entre outros. Esses exemplos podem indicar um processo de territorialização, de desterritorialização ou de reterritorialização.

A territorialização social está relacionada aos mecanismos de controle do espaço existente na sociedade contemporânea. Como se sabe, na pós-modernidade o que muda é a experiência social de espaço-tempo.

Em muitos sentidos, a obra de Michel Foucault preparou o terreno para essa investigação do funcionamento material do mando imperial. Em primeiro lugar, a obra de Foucault nos permite reconhecer uma transição histórica, de época, nas formas sociais da sociedade disciplinar para a sociedade de controle. ${ }^{7}$ (HARDT e NEGRI, 2002, p.42).

Logo, os termos sociedade disciplinar e sociedade de controle ganharam dimensão, fazendo-se necessário distinguir os tipos de controles que estão sendo produzidos, assim como os seus vínculos com a territorialização, a desterritorialização e a reterritorialização. Enquanto na sociedade disciplinar o enfoque era o indivíduo, "cada um em sua 'célula' espacial e temporalmente controlada", na "sociedade de controle" a tendência é a massificação, isto é, o controle se dá pelas máquinas. "Nessa passagem da sociedade disciplinar para a sociedade de controle, portanto, pode-se dizer que a relação cada vez mais intensa de mútua implicação de todas as forças sociais que o capitalismo buscou durante todo o seu desenvolvimento foi plenamente realizada." (HARDT e NEGRI, 2002, p.44).

\footnotetext{
${ }^{7}$ Nota dos próprios autores: "A passagem da sociedade disciplinar para a sociedade de controle não é articulada explicitamente por Foucault, mas continua implícita em sua obra. Adotamos os excelentes comentários de Gilles Deleuze nesta interpretação. Ver Gilles Deleuze, Foucault (Paris: Minuit, 1986); e 'Póst-scriptum sur les sociétés de controle', em Pourparles (Paris: Minuit, 1990). Ver também Michel Hardt, 'The Withering of Civil Society', Social Text, n॰ 45 (Winter 1995), 27-44.” (HARDT e NEGRI, 2002, p.43).
} 
De acordo com as reflexões dos autores, é importante que o contexto biopolítico seja analisado, uma vez que estão sendo estabelecidas novas relações de poder. Essas considerações, aplicadas ao território como um híbrido entre materialidade e imaterialidade e funcionalidade e expressividade, tornam a territorialização e a desterritorialização inseparáveis.

De certa maneira, os termos desterritorialização e rede podem ser usados para fazer referência às novas territorializações que estão sendo constituídas. Porém, desterritorialização não é sinônimo de rede. Nesse sentido, ocorreu a ruptura do controle do território a partir da definição de áreas e fronteiras para iniciar a experiência de se viver em redes, modo pelo qual a humanidade busca a sua identificação com o espaço em movimento. "Assim, territorializarse significa também, hoje, construir e/ou controlar fluxos/redes e criar referenciais simbólicos num espaço em movimento, no e pelo movimento.” (HAESBAERT, 2004, p.280).

Portanto, o território tem recebido novas acepções, entre as quais: "movimento", ritmo, fluxo, rede com significados funcionais e expressivos. O território-rede está associado à nova dimensão temporal-móvel do território, evidenciando-se a idéia de dinamismo e movimento, que se contrapõe à tradicional concepção de território-zona. Assim, as reflexões sobre território do ponto de vista geográfico poderão auxiliar nos estudos e debates sobre desterritorialização e multiterritorialidade.

Já as redes possuem um papel ambivalente, pois podem desencadear um processo de territorialização e de desterritorialização. São constituídas e/ou mobilizadas por ações de determinados sujeitos, uma vez que só assim se torna possível identificar os diferentes tipos de fatores, entre os quais o estratégico-funcional ou simbólico-expressivo, para compreender quando as redes estão desencadeando processos de territorialização. Tal situação pode ser caracterizada como uma ação estratégico-funcional.

De acordo com esta lógica, foram criados os termos região-rede, território em rede, território-rede e territórios de redes, o que modifica a noção clássica de território e inclui a noção de descontinuidade. Destarte, Haesbaert (2004) argumenta que entre as perspectivas teóricas identificadas na relação território e rede se pode citar três tipos: 1) uma que subordina a rede ao território; 2) uma que separa território e rede; e 3) uma que trabalha o binômio território-rede. 
Diante do exposto, percebe-se que a territorialização ocorre em torno desses territórios-rede, sendo a mobilidade entendida como um instrumento de poder e como a principal provocadora das descontinuidades, isto é, das diferenças de velocidades e de tipos de deslocamento. Vale, ainda, mencionar os diferentes tipos de deslocamento; ou seja, as pessoas se deslocam umas até mais do que outras e umas com mais lentidão do que outras. Essas diferenças de mobilidades estão relacionadas à distribuição desigual. Pode ser evidente que tanto os fluxos materiais quanto o fluxo de pessoas adquirirão importância econômica, política, cultural e ambiental.

Os termos território-rede, território-zona e aglomerados de exclusão podem ser utilizados para mencionar as possibilidades de organização espaço-territorial. Como exemplo pode-se citar a espacialidade da rede terrorista Al Qaeda, que pode ser entendida como uma organização que atua em diferentes territórios e, por isso, ser denominada de território-rede, já que apresenta um movimento constante de des-reterritorialização, atuando em torno de grupos sociais desterritorializados, que podem ser considerados como aglomerados de exclusão como, por exemplo, os da população mais pobre do interior do Afeganistão.

Em síntese, as diferentes formas de organização espaço-territorial podem ser agrupadas da seguinte maneira: territórios-zona (áreas, limites e fronteiras); territórios-rede (espacialidade descontínua); e aglomerados de exclusão (indefinidos). A associação entre os termos desterritorialização e aglomerados de exclusão pode ser aplicada à instabilidade ou fragilização territorial, pois é nesta lógica que se pode encontrar grupos socialmente excluídos e/ou profundamente segregados enfrentando dificuldades para exercerem o efetivo controle de seus territórios, tanto no sentido de dominação (político-econômica) quanto no sentido de apropriação (simbólico-cultural).

De certa maneira, a expressão "aglomerados de exclusão" está associada à dimensão geográfica ou espacial das contradições sociais que estão se tornando cada vez mais explícitas na sociedade contemporânea. Além do mais, há a possibilidade de se associar os termos aglomerados de exclusão (conjuntos, agrupamentos, aglomeração humana etc.) e desterritorialização ou territorialização precária. Destaca-se também que a análise da pobreza, comumente, perpassa apenas pela dimensão econômica (falta de recursos), embora possa incluir ainda a dimensão espacial, já que o território é visto como recurso de grande relevância para a reprodução social. 
Nessa perspectiva, o termo desterritorialização pode indicar exclusão, privação e precarização do território tanto no sentido material quanto no simbólico. Entretanto, destacase que a exclusão social e a privação territorial não ocorrem de forma completa, assim como a desterritorialização absoluta está relacionada a situações em que determinados espaços geográficos são vedados à territorialização. Logicamente, a exclusão territorial pode ocorrer na relação sociedade-natureza, tornando-se, então, a natureza territorializada excluída da sociedade. Entre os exemplos que se pode citar destacam-se: áreas completamente vedadas à habitação/circulação humana (reservas naturais e áreas protegidas); áreas militares; áreas afetadas por acidentes químicos; e depósitos de resíduos químicos, incluindo lixo nuclear.

O processo de etnicização do território pode ser considerado bastante ocorrente no Brasil, colocando as populações indígenas, por exemplo, no contexto dos aglomerados de exclusão e de reclusão. O Estado nação brasileiro considera as populações indígenas como frágeis e por isso, por um lado, tornou-se responsável pelo desenvolvimento de políticas públicas setoriais e, por outro, negou a autonomia para os grupos desta etnia. A Fundação Nacional do Índio (Funai), a Fundação Nacional da Saúde (Funasa), as Escolas Indígenas, as Organizações Não-Governamentais e as Associações Indígenas, entre outras Instituições, poderiam empregar um maior número de índios, o que muito contribuiria para a criação de renda local. Além disso, cada etnia poderia criar e apresentar as suas regras particulares de reivindicação de políticas públicas setoriais e de autonomia. No entanto, essa realidade se encontra pouco avançada em muitos grupos de indivíduos brasileiros.

No debate sobre desterritorialização e multiterritorialidade, Haesbaert (2004) aponta a ruptura entre a velha noção de território (mosaico-padrão de unidades territoriais em área) e a atual noção, que coloca a proposição da existência dos territórios-rede (descontinuidade, fragmentação, movimento). O capitalismo pós-fordista e a acumulação flexível são os responsáveis pela construção dos territórios-rede (pós-modernidade), assim como pela sobreposição aos territórios-zona (modernidade). Destaca-se, ainda, que as formas antigas de território (Estados nacionais) continuam existindo lado a lado com as atuais formas de organização territorial. De certa maneira, não existe indivíduo ou grupo social sem um território (material e/ou simbólico), assim como formas específicas de "desterritorialização", isto é, relações de domínio e de apropriação do espaço que expressam dimensões do poder. 
O território, portanto, possui um sentido bastante amplo. Em sua materialidade (física ou biológica), pode indicar recurso para a satisfação das necessidades básicas (subsistência); em seu sentido imaterial (simbólico, representação), significa a apropriação do território para a realização das manifestações culturais. A análise do território no seu sentido amplo inclui, assim, o aspecto temporal, o da atual dinâmica das redes em que determinados territórios encontram-se inseridos, o das perspectivas integradoras e, por último, o de suas múltiplas dimensões (de relações de poder).

Vale indicar também que há uma estreita aproximação entre multiescalaridade, multidimensionalidade e desterritorialização, pois são os sujeitos (indivíduos, grupos sociais e classes sociais) articulados às instituições públicas e/ou privadas que promovem a desterritorialização. Isto é, trata-se de uma reunião de sujeitos múltiplos que desenvolvem importantes ações, as quais devem ser consideradas em suas especificidades. Numa perspectiva de análise da territorialização, se pode afirmar que ela é o resultado da experiência integrada do espaço (território-rede, descontínuos, móveis e fragmentados) que se contrapõe à antiga proposição de experiência total do espaço (território-zona contínuo e relativamente estável).

$\mathrm{Na}$ atualidade, parece comum que se atribua uma ênfase à dinâmica dos territórios, isto é, aos seus aspectos de múltiplos territórios ou de multiterritorialidade, utilizando-se as concepções de territorialização, de desterritorialização e, em específico, a questão da(s) mobilidade(s) do(s) indivíduo(s) no espaço. Pode-se, assim, estabelecer diferenciações entre as diversas territorializações, que podem ser agrupadas, então, nas seguintes modalidades: territorializações mais fechadas; territorializações tradicionais; territorializações mais flexíveis; e territorializações efetivamente múltiplas. De certa forma, a multiplicidade de territórios está relacionada à diversidade de territórios que ainda podem ser encontrados, desde aqueles que estão sendo usados para a satisfação das necessidades básicas (subsistência e/ou abrigo) até os que podem ser vinculados ao ciberespaço.

A idéia de multiterritorialidade está relacionada à diversidade de territórios existentes ao redor do mundo, que possibilita a construção de múltiplos territórios (papel desempenhado pelas grandes metrópoles). Está relacionada também à possibilidade de se acessar e conectar diversos territórios, incluindo deslocamentos físicos e virtuais e as novas experiências espaçotemporais que podem ser encontradas no ciberespaço. Pode-se afirmar, assim, que a 
multiterritorialidade está relacionada com as possibilidades de experimentação de vários territórios e de promoção da integração territorial.

Atualmente, é possível interagir com diversos territórios por intermédio da internet ou dos diferentes tipos de transportes (aéreos, fluviais, marítimos e terrestres). Por isso, considera-se que é a condição social que permitirá a concretização das opções de desfazer e refazer a multiterritorialidade. Por um lado, foram engendradas alternativas territoriais, as quais estão relacionadas à facilidade de acesso e à expressiva velocidade de mudança. Por outro, menciona-se os principais elementos responsáveis pelas novas possibilidades de experiência espacial integrada, entre os quais: uma dimensão tecnológica; uma dimensão simbólica; o fenômeno do alcance planetário instantâneo; e a identificação espacial. Assim, a tendência atual revela que está chegando o fim da chamada territorialidade central, aquela dos Estados nações modernos (modernidade clássica), e a instauração de uma territorialidademundo e de uma identidade territorial global (problemas ambientais).

Diante do exposto, duas leituras podem ser identificadas sobre a multiterritorialização. A primeira se refere à multiterritorialidade moderna (embrionária, zonal ou de territórios de redes), e a segunda diz respeito à multiterritorialidade pós-moderna (reticular ou de territórios-rede). Destarte, os territórios das populações indígenas brasileiras podem ser considerados dentro da lógica da modernidade clássica, uma vez que o Estado nacional exerce o controle efetivo das territorialidades (terras) indígenas, estabelecendo que todo território indígena é considerado "terra (área) protegida", conforme o Artigo 231 da Constituição Federal de $1988^{8}$, o Artigo no $18, \S 1^{\text {o }}$, da Lei $n^{\circ} 6001 / 73^{9}$, e o Artigo 161 do Código Penal (Figura 01). ${ }^{10}$

\footnotetext{
${ }^{8}$ Com a elaboração da Constituição de 1988 ficou mais claro e evidente os Direitos dos Povos Indígenas: "BRASIL. Constituição de (1998). Constituição da República Federativa do Brasil: texto constitucional promulgado em 5 de outubro de 1988, com as alterações adotadas pelas Emendas Constitucionais n ${ }^{\circ} 1 / 92$ a 42/2003 e pelas Emendas Constitucionais de Revisão n ${ }^{\circ} 1$ a 6/94. Brasília: Senado Federal, Subsecretaria de Edições Técnicas, 2004".

${ }^{9}$ Para verificar com maiores detalhes ver a "LEI No 6.001 - De 19 de Dezembro de 1973 - Dispõe sobre O Estatuto do Índio".

${ }^{10}$ OLIVEIRA, J. Código Penal. 35 edição. São Paulo: Saraiva, 1997. (Coleção, legislação brasileira). p. 89-90.
} 
Figura 01 - Placa com informações sobre legislação dos territórios (terras) indígenas

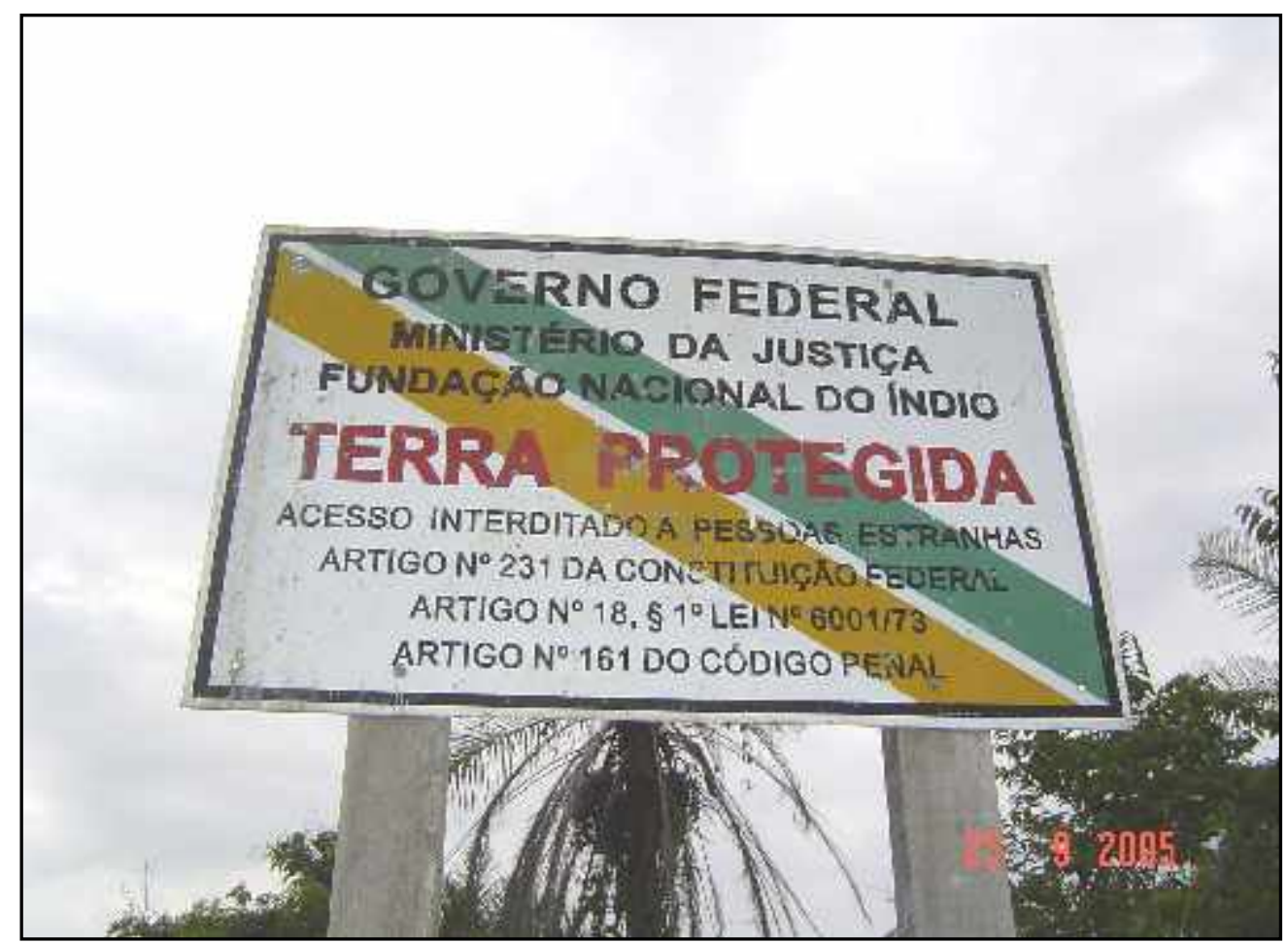

Fonte: autor, 2005.

Além disso, a OIT $169 / 1989^{11}$ propõe a diminuição da força e da opressão jurídicopolítica do Estado no controle dos territórios indígenas como territórios zona e/ou terras (área) protegidas. Por um lado, os territórios indígenas podem ser considerados fechados do ponto de vista da legislação, o que inibe a organização do turismo, e, por outro, por intermédio das ações das comunidades e das associações indígenas esses territórios podem ser analisados, compreendidos e identificados num outro sentido, isto é, da condição de territórios indígenas fechados para a condição de territórios indígenas abertos e mais flexíveis. ${ }^{12}$ Vale mencionar

${ }^{11}$ Este documento permite visualizar com mais profundidade a atual situação dos povos indígenas e tribais ao redor do mundo: CONVENÇÃO No 169 DA OIT SOBRE POVOS INDIGENAS E TRIBAIS E RESOLUÇÃO REFERENTE À AÇÃO DA OIT SOBRE POVOS INDIGENAS E TRIBAIS. Brasília: OIT, 2004.

12 "O que a igualdade é para o corpo político - seu princípio intrínseco -, a discriminação é para a sociedade. A sociedade é essa esfera curiosa, um tanto híbrida, entre o político e o privado em que, desde o início da era moderna, a maioria dos homens tem passado a maior parte da vida. Pois cada vez que abandonamos as quatro paredes protetoras de nosso lar e cruzamos o limiar do mundo público, entramos primeiro não na esfera política da igualdade, mas na esfera social. Somos impelidos a entrar nessa esfera pela necessidade de ganhar a vida, atraídos pelo desejo de seguir a nossa vocação, ou incitados pelo prazer da companhia; uma vez lá dentro, nos tornamos sujeitos ao velho adágio 'o 
também que os territórios indígenas podem ser analisados, compreendidos e identificados na ótica da desterritorialização, da reterritorialização e da multiterritorialidade.

\subsection{CULTURAS HÍBRIDAS, TURISMO, MODERNIDADE E PÓS-MODERNIDADE}

Canclini (2003) contribui para a análise do termo culturas híbridas, além de abrir a possibilidade de investigar, interpretar e identificar a hibridização do turismo no contexto da modernidade e da pós-modernidade. Para não fugir da lógica das discussões dos itens anteriores deste capítulo, o turismo está sendo estudado nas perspectivas política, econômica, cultural e ambiental. Espera-se construir uma análise do turismo que leve em consideração o sentido relacional de território, bem como a experiência integrada do espaço, de modo que a abordagem dos termos território, desterritorialização e reterritorialização foi necessária para assegurar o compromisso com a teoria.

Nesta lógica, o termo culturas híbridas pode ser considerado em voga nas Ciências Humanas, principalmente nos estudos da temática "culturas populares".

É nesses cenários que desmoronam todas as categorias e os pares de oposição convencionais (subalterno/hegemônico, tradicional/moderno) usados para falar do popular. Suas novas modalidades de organização da cultura, de hibridação das tradições de classes, etnias e nações requerem outros instrumentos conceituais. (CANCLINI, 2003, p.283).

De um lado estão as manifestações culturais, que parecem estar cada vez mais mescladas, podendo-se dizer que brotam de seus entrecruzamentos, e de outro está a interpretação desta complexidade denominada hibridação intercultural.

Os turistas podem ser considerados os que estão se deparando com as culturas híbridas. Algumas localidades são construídas e elaboradas dentro dos padrões técnicos híbridos para atender um público que busca manifestações culturais deste tipo. Destaca-se que

semelhante atrai o semelhante' que controla toda a esfera da sociedade na variedade inumerável de seus grupos e associações. O que importa nesse caso não é a distinção pessoal, mas as diferenças pelas quais as pessoas pertencem a certos grupos cuja própria possibilidade de identificação exige que elas discriminem outros grupos no mesmo âmbito." (ARENDT, 2004, p.273). 
a cidade pode ser considerada um dos objetos de estudo bastante investigados pelas Ciências Humanas, que, então, extraem novos entendimentos sobre as transformações culturais.

De certa maneira, os reflexos do processo de urbanização deixaram explícito que não existe uma oposição entre os moradores urbanos e os rurais. Por um lado, as inovações tecnológicas chegam até os moradores rurais e, por outro, os gostos de uns e de outros coincidem. Por isso, pode-se considerar que há uma constante interação entre moradores urbanos e rurais, envolvendo as populações tradicionais e indígenas. Todos têm acesso às possibilidades oferecidas pelas inovações (o rádio, a televisão, a antena parabólica, o computador), as quais disponibilizam em cada domicílio informações e entretenimento.

De um lado, a cidade encontra-se numa crise de representação política e, de outro, pode-se mencionar o crescimento de reivindicações culturais de diversos grupos sociais (movimentos sociais urbanos, étnicos, juvenis, feministas, de consumidores, ecológicos). Os movimentos sociais, para se tornarem expressivos, dependem da reorganização do espaço público, incluindo o uso de novas tecnologias no lugar de formas tradicionais de comunicação. As cidades se encontram organizadas dentro de padrões técnicos de funcionamento, sendo que o entretenimento tornou-se diversão programada e compatível com a renda econômica de cada grupo social.

Numa outra lógica, os grupos sociais não atendidos buscam inclusão social. Destarte, é na cidade que ocorre a sociabilidade entre familiares e amigos para se tratar de assuntos cotidianos (aumento do preço do combustível, carnaval, política brasileira, novos destinos turísticos etc.), de modo que a urbe é representada no noticiário cotidianamente, simulando um imaginário urbano desagregado. Os meios de comunicação (sobretudo o rádio, a televisão e a internet) contribuem na tessitura do sentido social e coletivo do que ocorre na cidade. Cabe ressaltar que ainda faz-se necessário investigar os efeitos integradores e dissolventes dos meios de comunicação, incluindo também os processos de unificação e atomização responsáveis pelas mudanças urbanas.

A cidade tende a tratar o cidadão como cliente ou público consumidor. De um lado, tem-se a publicidade comercial (estimulo ao consumo) e, de outro, os lemas políticos (os discursos dos políticos), de modo que a liberdade de expressão, as reivindicações e as denúncias são realizadas pela televisão. Exibir-se na televisão tornou-se regra para reivindicar a inclusão social nos sentidos econômico, político, cultural e do meio ambiente, isto é, pode 
ser uma forma de lutar pela democracia e por um sentido público que está sendo construído a partir de experiências de longa duração.

Igualmente, os moradores rurais, em específico as populações indígenas, utilizam a televisão para fazer suas reivindicações. No Território Indígena Apinayè (nas aldeias São José, Riachinho, Mariazinha e Cocalinho), por exemplo, de outubro de 2005 até o final do mês de janeiro de 2006 faleceram dezesseis (16) crianças entre zero (0) e seis (06) anos de idade. Após a realização de uma reportagem com os índios das referidas aldeias, construiu-se a sensibilização social, envolvendo a sociedade e as autoridades públicas no tratamento da questão. As populações indígenas, ao concederem entrevistas e imagens, permitiram que a sociedade brasileira tomasse conhecimento das atuais condições de saúde dos índios. As populações não-indígenas, ao questionarem uns e outros sobre os motivos que estavam levando as crianças à morte, contribuíram no sentido de obter uma resposta imediata da Fundação Nacional da Saúde (Funasa), solucionando parcialmente as causas de mortalidade infantil.

As tecnologias comunicativas, portanto, podem provocar o desmantelamento da transferência da cultura. Isto é, o que se dava a partir da tradição e da oralidade passa a acontecer sob a forma de teleparticipação, que substitui a herança do passado e as interações públicas. Deve-se re-introduzir as questões dos usos modernos e pós-modernos da história. Para isto, faz-se necessário analisar a importância dos monumentos, da publicidade, dos grafites e dos movimentos sociais (políticos). Das nuances destes diferentes contextos pode ser possível capturar as tendências recentes das transformações das cidades no sentido da conservação e da renovação.

Canclini (2003) argumenta que os poderes econômico, político e cultural se expressavam na cultura material, ou seja, em edifícios, murais, retratos de heróis nacionais, calendários e efemérides, símbolos que representavam as utopias do poder que se encontrava instaurado nos vários países da América Latina. De um lado, têm-se os monumentos como uma simbologia urbana e, de outro, inaugura-se uma nova cultura visual, sobrepondo os signos da velha ordem, de modo que ocorrem tensões entre os velhos e os novos símbolos das cidades modernas.

Comumente, até os monumentos considerados patrimônios passam por transformações, recebendo novos estilos e referências de diversos períodos históricos e artísticos. A reunião de vários estilos, as referências a diversos períodos históricos e artísticos, 
o crescimento urbano, a publicidade, os grafites e os movimentos sociais modernos constituem elementos e questões de hibridização cultural. As classificações rigorosas das coisas e das linguagens indicam a organização sistemática dos espaços sociais onde as mercadorias deverão ser consumidas.

A ordem pode prescrever comportamentos e modos de percepção para cada situação anunciada, ao mesmo tempo em que a tensão urbana procura transgredir o que está de forma ordenada. As manifestações culturais urbanas, por meio das irreverências dos cidadãos, demonstram dúvidas quanto à velha ordem. Parece ser evidente que existe uma distância entre um Estado e um povo, a história e o presente, assim como a necessidade de se reescrever politicamente os monumentos.

Nesta lógica, a cultura urbana não pode ser explicada a partir das coleções de bens simbólicos. A "desarticulação do urbano põe em dúvida que os sistemas sociais encontrem sua chave nas relações da população com certo tipo de território e de história que prefigurariam em um sentido peculiar os comportamentos de cada grupo" (CANCLINI, 2003, p.302). Por isso, o autor propõe a análise dos termos descolecionamento e desterritorialização.

Como se sabe, a formação de coleções especializadas de arte culta e folclore ocorreu na Europa e, em seguida, na América Latina, onde os bens simbólicos foram organizados em grupos específicos e hierarquizados. Destarte, estamos vivendo numa época em que colecionar não é mais a regra para organizar os bens simbólicos, nem as bibliotecas, embora os arquivos públicos possam ser considerados relevantes. No entanto, cada intelectual organiza a sua biblioteca (misturando revistas, recortes de jornais, informações fragmentadas), seguindo regras e necessidades individuais. Neste sentido,

[...] havia um repertório do folclore, dos objetos de povos ou classes que tinham outros costumes e por isso outras coleções. O folclore nasceu do colecionismo [...]. Foi se formando quando os colecionadores e folcloristas se transferiam a sociedades arcaicas, investigavam e preservavam as vasilhas usadas nas refeições, os vestidos e as máscaras com que se dançava nos rituais e os reunia em seguida nos museus. As vasilhas, as máscaras e os tecidos encontram-se igualados agora sob o nome de "artesanato" nos mercados urbanos. Se queremos comprar os mais bem feitos já não vamos para as serras ou para as selvas onde vivem os índios que os produzem, porque as peças de diversos grupos étnicos se misturam nas lojas das cidades. (CANCLINI, 2003, p.303). 
Pode-se dizer que o folclore nasceu do colecionismo dos colecionadores e folcloristas, que reuniram de forma organizada a cultura material (vasilhas, vestimentas, máscaras, artefatos em geral usados nos rituais) e a guardaram nos museus. Estes mesmos objetos têm sido transformados em artesanatos e vendidos no mercado urbano das pequenas, médias e grandes cidades. Assim, um objeto considerado sagrado (utilizado em determinados rituais) por um determinado grupo étnico pode ser transformado em artesanato. ${ }^{13}$

Atualmente, os índios Krahô utilizam o modelo do Machado de Pedra Seminular (um dos exemplares se encontra no Museu Goeldi, em Belém - PA) para fazer o Machado de Madeira Seminular sob a forma de artesanato. Ribeiro (1988), na obra intitulada "Dicionário do Artesanato Indígena", traz uma minuciosa pesquisa sobre os diferentes artesanatos das populações indígenas brasileiras, destacando entre estes: os objetos de cerâmica; os trançados; os cordões e tecidos; os adornos plumários; os adornos de materiais ecléticos; a indumentária; o toucador; os instrumentos musicais e de sinalização; as armas; os utensílios e implementos de madeira e outros materiais; e os objetos rituais, mágicos e lúdicos.

As diferentes populações indígenas ao redor do mundo buscam no artesanato (arte de fato) construir referências culturais e produzir para o mercado, de modo que no presente momento histórico se pode ter objetos simbólicos que a priori apenas os museus possuíam. As pessoas podem organizar os seus objetos simbólicos (indígenas e não-indígenas) adquirindo-os no mercado. Os artesanatos indígenas estão sendo expostos para a venda nas mesmas lojas que oferecem artesanatos não-indígenas; isto é, pode ser possível identificar artesanatos de diversos grupos étnicos de várias localidades ao redor do mundo nas lojas de Shoppings Centers de uma grande cidade como São Paulo, e também em pequenas lojas nas cidades pequenas e médias, onde o mercado é formado basicamente por turistas.

As relações interétnicas e interculturais entre os indígenas e os hipp's permitem que, por intermédio do contato cultural entre uns e outros, novas experiências sejam trocadas, de modo que o artesanato indígena influencia o artesanato dos hipp's e vice-versa. Esta mistura da arte de fazer artesanatos entre indígenas e não-indígenas pode ser considerada como um processo de hibridização cultural. Entre outros exemplos de hibridização cultural, pode-se

\footnotetext{
${ }^{13}$ Por exemplo: "Machado de Pedra Seminular Def. Artefato de pedra, em forma de ancora ou de meia lua, atado a um cabo por envoltório decorativo de fios de algodão e provido de alça para carregar. Segundo Nimuendaju (1939: 126), a área de distribuição dos machados em âncora coincide com a dos grupos Jê. Referindo-se aos Apinayè, esse autor opina que essa arma deve ter sido usada para ultimar o inimigo na guerra e, ao findarem estas, como objeto ritual (op. Cit.: 127)." (RIBEIRO, 1988, p.304).
} 
citar o uso das fotocopiadoras (vários textos de autores diferentes na mesma apostila), do videocassete $^{14}$ (coleção individual), do DVD (coleção individual), dos videoclips (coleção individual) e dos videogames (vários tipos de jogos). Assim, os sentidos das tecnologias estão sendo construídos de acordo com as formas que se institucionalizam e se socializam.

É evidente que as inovações provocam intervenções tecnológicas tanto nas culturas tradicionais quanto nas modernas e pós-modernas; é por isso que ocorre uma reorganização entre os grupos sociais e seus sistemas simbólicos e que os descolecionamentos e as hibridações modificam a leitura rígida da relação entre as classes sociais e os estratos culturais. Ainda que muitas obras permaneçam dentro dos circuitos minoritários ou populares para que sejam feitas, a tendência predominante é que todos os setores misturem em seus gostos objetos de procedências antes separadas. Logicamente, as tendências recentes apontam que a reorganização dos cenários culturais e os cruzamentos constantes das identidades exigem a análise, a sistematização e a reflexão das relações materiais e simbólicas entre os diferentes grupos sociais.

A descoleção e a desterritorialização podem ser consideradas a priori de conhecimento de artistas e de intelectuais (no sentido utópico), de modo que os termos descoleção, desterritorialização e hibridez pós-moderna manifestam fragilidades, pois as práticas dos artistas exigem novos paradigmas. As obras de arte, quando reunidas e preservadas nos museus, tornam-se institucionalizadas, enquanto o artesanato pode ser preservado num museu popular ou em livros para turistas.

No entanto, continua em aberto o questionamento: até que ponto a arte culta e a popular constroem sentidos em suas mesclas inevitáveis e estabelecem interação com a simbologia massiva? Segundo Canclini (2003), pode-se considerar como gêneros constitucionalmente híbridos o grafite e os quadrinhos. $\mathrm{O}$ traço manual do grafite contradiz e desafia sobretudo as linguagens institucionalizadas, pois elas são alteradas. Nesta lógica, o grafite demonstra o quadro de contradições existentes nas cidades. Na América Latina, um grafite carregado de deboche e cinismo expressou a realidade da desordem urbana, além de revelar a constante perda de credibilidade das instituições políticas e o desencanto utópico.

\footnotetext{
${ }^{14}$ A biblioteca da Escola Catxêkwyj - Vicência Agro ambiental (sede da Kapey) possui um acervo de documentários sobre populações indígenas de várias etnias. Consideram-se também os documentários sobre a população indígena Krahô e de outras etnias, dividindo a mesma prateleira de fitas de vídeos com documentários educativos sobre agrofloresta, meio ambiente e desenvolvimento sustentável.
} 
Já as histórias em quadrinhos ganharam bastante projeção, a ponto de tornarem-se um componente central da cultura contemporânea, envolvendo a cultura icônica e a literária, de modo a condensar novos valores artísticos nas imagens estáticas e fazer sucesso de público e venda. Por isso, tem-se a prática de: políticas neoconservadoras, falta de alternativas socializantes, distância entre democracia e inovações tecnológicas e, por último, instauração de uma complexa crise social.

Sobre as hibridações, Canclini (2003) argumenta que se pode concluir que hoje todas as culturas são de fronteira, uma vez que as artes se desenvolvem em relação com outras artes, o artesanato migra do campo para a cidade e os filmes, os vídeos e as canções narram histórias semelhantes (apresentando intercâmbios). As culturas estão, portanto, descentralizadas, multideterminadas e com novos recursos (potencialidades) de comunicação e de conhecimento. Igualmente, o turismo em territórios indígenas e o turismo indígena se inserem neste novo contexto da hibridização cultural que está presente na modernidade. 


\section{CAPÍTULO 2 - TURISMO, TERRITÓRIO, MODERNIDADE E DESENVOLVIMENTO LOCAL}

O presente capítulo tem por objetivo propor uma discussão sobre turismo, território, modernidade e desenvolvimento local. Para isto, estão sendo utilizadas as matrizes teóricas dos referidos termos e as categorias de análise da Geografia no contexto das Ciências Humanas, procurando-se, assim, estabelecer interfaces teóricas e metodológicas.

O turismo tem sido considerado adotando-se cada vez mais abordagens multidisciplinares, envolvendo várias áreas do conhecimento científico e tomando de empréstimo concepções diferentes. Dessa forma, procura-se promover o entendimento analítico do turismo e de suas novas segmentações.

De acordo com Cunha e Almeida (2001, p.184):

Numa surpreendente mudança de rumo ideológico, as populações tradicionais da Amazônia, que até recentemente eram consideradas como entraves ao "desenvolvimento", ou na melhor das hipóteses como candidatas a ele, foram promovidas à linha de frente da modernidade.

De certa maneira, as populações indígenas e tradicionais passaram a ser consideradas como modelos na prática de conservação ambiental, uma vez que as ações locais têm assumido um papel importante nas escalas nacional e internacional. No dizer dos referidos autores:

Definir as populações tradicionais pela adesão à tradição seria contraditório com os conhecimentos antropológicos atuais. Defini-las como populações que têm baixo impacto sobre o meio ambiente, para depois afirmar que são ecologicamente sustentáveis, seria mera tautologia. Se as definirmos como populações que estão fora da esfera do mercado, será difícil encontrá-las hoje em dia. (CUNHA e ALMEIDA, 2001, p.184).

Nesta mesma lógica, termos como índio, indígena, tribal, nativo, aborígene e negro são todos provenientes do período colonial. Com relação à categoria "populações tradicionais", incluindo seringueiros e castanheiros da Amazônia, coletores de berbigão de Santa Catarina, babaçueiras do sul do Maranhão e quilombolas do Tocantins, pode-se 
observar que em troca do controle sobre o território assumem o compromisso de prestar serviços ambientais. ${ }^{15}$

De certa forma,

Nos últimos vinte anos, os povos indígenas na Amazônia avançaram muito. Na década de 1970, governadores não se pejavam de referir-se a eles como "entraves ao progresso". Políticos de direita e militares colocavam-nos sob suspeição, achando que a única explicação para o interesse internacional dirigido a eles era a cobiça. Nesse período, lamentar o "fim do índio" era lugar-comum. Uns atribuíam esse "fim do índio" à marcha inexorável, enquanto alguns intelectuais de direita atribuíam-no à não menos inexorável marcha da história. A marcha acelerada desses batalhões não permitia sobreviventes. (CUNHA e ALMEIDA, 2001, p.185).

A partir dos anos 1980, a população indígena passou a registrar crescimento, contradizendo as perspectivas dos dados estatísticos das décadas anteriores. Hoje, tal grupo de indivíduos continua mantendo índices de aumento, o que pode levar a pensar que os índios estão no Brasil para ficar. Neste sentido,

Embora estejam disseminadas, a extensão das terras indígenas em conjunto impressiona. Os Índios tem direito constitucional a quase $12 \%$ por cento do território brasileiro, com terras distribuídas em 574 áreas diferentes e abrangendo 20\% da Amazônia Brasileira. As unidades de conservação da Amazônia onde é permitida a presença humana, as unidades conservação de uso direto, cobrem outros 8,4\% da região. (CUNHA e ALMEIDA, 2001, p.187).

No que se refere às práticas indigenistas, estas podem ser entendidas a partir da proposta do etnólogo Darcy Ribeiro ou da concepção dos antropólogos Manuela Carneiro da Cunha e João Pacheco de Oliveira Filho, embora defendam proposições diferentes para solucionar os problemas das populações indígenas brasileiras. O etnólogo, e também antropólogo, Darcy Ribeiro "Identifica que a problemática indígena se constitui na relação com o homem branco, nas relações de contato. O caráter desigual dessa relação, francamente

\footnotetext{
${ }^{15}$ Nota dos próprios autores: "Embora, como buscaremos mostrar, as populações tradicionais tenham tomado os povos indígenas como modelos, categoria 'populações tradicionais' não os inclui. A separação repousa sobre uma distinção legal fundamental: os direitos territoriais indígenas não são qualificados em termos de conservação, mesmo quando se verifica que as terras indígenas figuram como 'ilhas' de conservação ambiental em contextos de acelerada devastação. Para realçar essa especificidade da legislação brasileira que separa os povos indígenas das 'populações tradicionais', não os incluiremos nesta categoria, e estaremos usando quando necessário, a expressão 'populações indígenas e tradicionais'.” (CUNHA e ALMEIDA, 2001, p.184).
} 
favorável ao branco, chama a um controle e uma intervenção por parte do Estado" (SCHETTINO, 2002, p.06). Paralelamente, Manuela Carneiro da Cunha e João Pacheco de Oliveira Filho afirmam que o Estado tem demonstrado ser um adversário dos interesses indígenas. Assim sendo:

[...] as demandas indígenas não se detém exclusivamente no acesso à terra, cada vez mais direcionando-se para a posse e a gestão dos territórios reconquistados, a geração de renda, novas estratégias de sobrevivência, atendimento das necessidades da população indígena presente nas cidades e urbanização dessas populações. (SCHETTINO, 2002, p.07).

Atualmente, as populações indígenas estão buscando desenvolver os seus próprios projetos e procurando novas alternativas de sobrevivência. As tendências recentes revelam que os índios reivindicam o fim da tutela do Estado, isto é, menos assistencialismo, assim como a definição de políticas públicas setoriais.

O turismo está entre as atividades econômicas que estão sendo discutidas em territórios indígenas como produtos da modernidade que podem ensejar o desenvolvimento com base local, dependendo das condições do seu processo em implantação e estruturação. Este constitui o objeto de estudo central a ser tratado neste capítulo, procurando-se enfocar o atual estágio em que se encontra a organização do turismo no território indígena Krahô.

\subsection{POPULAÇÃO INDÍGENA KRAHÔ POR TRADIÇÃO}

A população indígena Krahô possui suas peculiaridades no que diz respeito às tradições, as quais foram interpretadas a partir do contato interétnico no início do século XIX. Antes deste período, as noções sobre os seus costumes restringiam-se a hipóteses de como eram os seus hábitos.

As tradições consideradas antigas são mantidas por meio da realização de rituais, que têm uma forte relação com os elementos da natureza, tais como o sol (Pyt), a lua (Pytwrýré), a terra (Pjê), a água (Cô), a árvore (Pîhkô) e a fauna. Tomando-se como referência o passado e o presente, a população indígena Krahô tem uma forte relação com o passado, o que faz com que as suas tradições assumam formas "autênticas". Compreende-se "tradições autênticas" 
como aquelas que não foram inventadas, como, por exemplo, as que pertencem às sociedades modernas e são institucionalmente formalizadas. ${ }^{16}$

É evidente que as tradições inventadas estabelecem vínculos com o passado, perspectivando a continuidade de uma forma artificializada. As situações novas têm como estrutura de referência as situações anteriores (passado remoto) identificadas dentro de um contexto artificial, assumindo importância e se repetindo com obrigatoriedade. "A 'tradição' neste sentido deve ser nitidamente diferenciada do 'costume', vigente nas sociedades ditas 'tradicionais'." (HOBSBAWM, 1997, p.10). De certa maneira, as tradições têm o intuito de manter a invariabilidade, isto é, de promover uma maior aproximação com o passado.

Os grupos indígenas brasileiros podem ser compreendidos como comunidades tradicionais cuja transferência da cultura acontece pela oralidade, uma vez que tais povos têm pouco domínio da escrita, não existindo literatura extensa na própria língua. De acordo com Hobsbawm, “O 'costume', nas sociedades tradicionais, tem a dupla função de motor e volante. Não impede as inovações e pode mudar até certo ponto, embora evidentemente seja tolhido pela exigência de que deve parecer compatível ou idêntico ao precedente" (HOBSBAWM, 1997, p.10).

O artigo de Mota (2000, p.03-10) intitulado “As guerras de conquista nos territórios indígenas Kaigang, Xokleng, Xetá e Guarani” contribui para a análise da integração das populações indígenas às populações não-indígenas regionais no Brasil. Nesse sentido, “Acreditava-se, até os anos 1970, que os índios no Brasil não tinham futuro nem passado. Colocavam-se como irreversíveis a sua assimilação à sociedade envolvente e seu fim diante do avanço nas áreas de fronteira” (MOTA, 2000, p.03). Desta concepção, igualmente, deriva a influência das teorias que os antropólogos adotaram para realizar suas pesquisas, desconsiderando a importância dos fundamentos da Geografia e da História nos estudos dos povos indígenas.

\footnotetext{
${ }^{16}$ Já 'por 'tradição inventada' entende-se um conjunto de práticas, normalmente reguladas por regras tácita ou abertamente aceitas; tais práticas, de natureza ritual ou simbólica, visam inculcar certos valores e normas de comportamento através da repetição, o que implica, automaticamente; uma continuidade em relação ao passado. Aliás, sempre que possível, tenta-se estabelecer uma continuidade com um passado histórico apropriado. Exemplo notável é a escolha deliberada de um estilo gótico quando da construção da sede do Parlamento britânico no século XIX, assim como a decisão igualmente deliberada, após a II Guerra, de reconstruir o prédio da Câmara partindo exatamente do mesmo plano básico anterior. O passado histórico no qual a nova tradição é inserida não precisa ser remoto, perdido nas brumas do tempo.” (HOBSBAWM, 1997, p. 09-10).
} 
Conforme aponta Manuela Carneiro da Cunha, seu passado não era objeto dos historiadores, por motivos metodológicos. Pois, como estudar povos sem escrita? Temiase o campo das tradições orais, ou o mergulho na documentação produzida pelos agentes da conquista: religiosos, administradores, viajantes, militares, etc. (MOTA, 2000, p.03).

Verifica-se, assim, que os antropólogos encontraram justificativas em teorias como o evolucionismo (os índios eram interpretados como no início da evolução, portanto, sem passado), o funcionalismo e o estruturalismo.

As questões metodológicas, até então compreendidas como impedimentos para o estudo das sociedades sem escrita, foram resolvidas quando a História, na década de 1970, passou a estudar assuntos relacionados à cultura popular, deixando de utilizar apenas os métodos convencionais e forjando novos métodos para legitimar novas fontes. De qualquer modo, os novos métodos adotados na História permitiram que as populações indígenas fossem investigadas a partir de suas oralidades e mitologias.

Para tornarem-se manifestas as proposições do Estado, segundo Mota:

Nas relações entre o estado colonial, imperial e republicano e as populações indígenas, foi construída toda a proposição de mundo com a intenção de impor o significado da "situação colonial" ou da "ocidentalização" do mundo às populações indígenas no Brasil. No entender da elite construtora do Estado brasileiro, ou essas populações civilizavam-se, ou seja, seriam conquistadas pelas idéias, ou seriam submetidas (exterminadas) pela tecnologia militar dos conquistadores nacionais. (MOTA, 2000, p.04).

A partir destas concepções, colocou-se em prática a política de integração das populações indígenas à sociedade envolvente. Práticas semelhantes ocorreram nos demais países da América Latina, seguindo o modelo de Estado nacional napoleônico, de modo que o plano era a negação do caráter pluriétnico das populações, isto é, as políticas adotadas tinham como objetivo principal integrar as populações indígenas e dissolvê-las nas populações brancas regionais. Os territórios indígenas Kaigang, Xokleng, Xetá e Guarani foram submetidos à conquista e à ocupação, mas estas comunidades lutaram para impedir as práticas dos conquistadores, demonstrando força e resistência.

Como se sabe, os estudiosos das populações indígenas entendem que o território possui um sentido muito importante, principalmente quando tais povos reivindicam os territórios comuns, tendo como referência o passado e tempos imemoriais. Nesse sentido, 
existem estudos que são elementares e que permitem a compreensão da relação entre sociedade e território na contemporaneidade.

Costa (1992, p.24) enfatiza que:

Um ponto de partida para uma análise como essa pode referenciar-se a alguns fundamentos teóricos que interessam à relação mais geral entre sociedade e espaço. Mais especificamente, e adotando um determinado modo de abordar esse processo, pode-se afirmar que toda sociedade, em qualquer tempo e lugar, define formas particulares de relações com o seu espaço de vivência e produção; em outras palavras, valoriza-o a seu modo. $^{17}$

O território das populações indígenas tem um enfoque específico por se tratar de um território comum, por ser o sistema social definidor de suas atribuições.

Evans-Pritchard (2002) estudou os Nuer, grupo nilota do Sudão, em 1935 e 1936, constituindo um trabalho de pesquisa importante e de referência para o estudo do território numa perspectiva antropológica. Costa (1992) já havia utilizado esta obra para fazer reflexões sobre a Geografia Política. Sendo assim, o território para as populações indígenas tem um outro sentido, por ser utilizado para satisfazer as necessidades básicas da sobrevivência. Portanto, o território é concebido pela comunidade de acordo com a vida social que é constituída.

Ao descrever os conceitos nuer de tempo, podemos fazer uma distinção entre aqueles que são principalmente reflexos de suas relações com o meio ambiente - que chamaremos de tempo ecológico - e os que são reflexos de suas relações mútuas dentro da estrutura social - que chamaremos de tempo estrutural. Ambos referem-se a sucessões de acontecimentos que a comunidade os note e relacione, uns aos outros, conceitualmente. Os períodos maiores de tempo são quase que inteiramente estruturais, porque os acontecimentos que relacionam são mudanças no relacionamento de grupos sociais. Além disso, o cálculo do tempo baseado nas mudanças da natureza e na resposta do homem a elas limita-se a um ciclo anual e, portanto, não pode ser empregado para diferenciar períodos mais longos do que estações do ano. (EVANS-PRITCHARD, 2002, p.107-8).

Costa (1992) interpretou o trabalho de Evans-Pritchard (2002), sobretudo as suas reflexões sobre espaço ecológico e espaço estrutural, propondo, também, a partir desta interpretação, um entendimento sobre território. É evidente que o território para as populações indígenas, tribais ou não, pode ser entendido sob a lógica do território comum. Como se sabe,

${ }^{17}$ Nota do próprio autor: "Essa idéia encontra-se desenvolvida em MORAES, Antonio Carlos R. Costa, Wanderley M., Geografia Crítica. A valorização do espaço. São Paulo, Hucitec, 1984.” 
a organização social tem a sua base de sustentação na estrutura de parentesco, famílias e clãs, constituindo, assim, um sistema social, que é mantido pela força da tradição.

Uma tribo foi definida por: 1 . um nome comum e distinto; 2 . um sentimento comum; 3 . um território comum e distinto dos demais; 4. uma obrigação moral de unir-se para a guerra; e 5. uma obrigação moral de resolver brigas e disputas através de arbitramento; 6 . uma tribo é uma estrutura segmentada e há oposição entre seus segmentos; 7. dentro de cada tribo existe um clã dominante e a relação entre a estrutura de linhagem desse clã e o sistema territorial da tribo é de grande importância estrutural; 8. uma tribo constitui uma unidade dentro de um sistema de tribos; e 9. os conjuntos etários são organizados tribalmente. (EVANS-PRITCHARD, 2002, p.135-6).

De acordo com os pensamentos de Evans-Pritchard (2002) e Costa (1992), o sistema tribal dos Nuer está baseado no território comum, na oposição às outras tribos e na estrutura comum de linhagem de um clã dominante. As relações de forças têm como referencial os vínculos com o espaço e com os vizinhos, formando um sistema político territorial.

Outro trabalho de pesquisa que Costa (1992) citou em sua obra de Geografia Política foi o estudo de Florestan Fernandes (1970), o qual também será utilizado para ilustrar a discussão sobre território e populações indígenas.

A análise sistemática da função social da guerra na sociedade tupinambá [...]. Alguns especialistas designam-no com a expressão função ecológica da guerra, levando em consideração a parte tomada pela guerra na adaptação das sociedades humanas ao meio natural circundante. Contudo, parece-me desnecessário complicar de tal modo a terminologia sociológica: o conceito de função social abrange naturalmente esta esfera da realidade. Além disso, basta que se tome o cuidado de referi-la como "função social da guerra no plano ecológico" para se obter uma particularização conceptual suficientemente clara. (FERNANDES, 1970, p.42).

Tanto Evans-Pritchard (2002) quanto Fernandes (1970) sustentam a proposição da universalidade das relações culturais e sociais como definidora das políticas territoriais. Nesse sentido, os casos dos Nuer, na África, e dos Tupinambás, no Brasil, envolvem disputas de territórios, e não somente do território em si, mas do que este representa para as referidas populações indígenas e tribais, isto é, manter o domínio do território é assegurar as condições básicas para a subsistência.

Rodrigues (2001), em sua tese de doutorado, intitulada "Limites do consenso: territórios polissêmicos na Mata Atlântica e a Gestão Ambiental Participativa", expõe que não existe consenso a respeito da relação cultura e espaço. Os caiçaras, os quilombos e as etnias 
indígenas podem ser mencionados como casos específicos de uma categoria universal. Cada comunidade tem as suas particularidades e, portanto, estabelece relações de espaço e cultura.

Toda sociedade, ao ter o seu espaço de vivência e de produção, tem também um espaço político, com perspectiva de projeção territorial, a qual passa a ser gerida pelo sistema sócio-cultural. Costa (1992, p.27), a esse respeito, afirma:

É evidente que à medida que a complexidade da organização social e política aumenta, e as diferentes sociedades passam a estruturar-se mediante sistemas formais de poder mais desenvolvidos, a tendência é que essas relações tornem-se mais explícitas e que a nitidez do espaço político também aumente. Dado o caráter deste processo, independe aí se estamos diante de sociedades organizadas, ou não sob a forma clássica de estado.

Outra contribuição importante para a análise do território é a de Santos e Silveira (2001, p.19-20), que propõem uma nova abordagem:

Num sentido mais restrito, o território é um nome político para o espaço de um país. Em outras palavras, a existência de um país supõe um território. Mas a existência de uma nação nem sempre é acompanhada da posse de um território e nem sempre supõe a existência de um Estado. Pode-se falar, portanto, de territorialidade sem Estado, mas é praticamente impossível nos referirmos a um estado sem território. Adotando-se essa linha, impõe-se a noção de "espaço territorial": um Estado, um espaço, mesmo que as "nações" sejam muitas. Esse espaço territorial está sujeito a transformações sucessivas, mas em qualquer momento os termos da equação permanecem os mesmos: uma mais nações, um Estado, um espaço.

Assim, refletir sobre o território ao mesmo tempo em que sobre a população indígena Krahô pode facilitar as suas compreensões nos sentidos teórico e prático. Sendo assim, podese afirmar a existência de uma forte relação entre tradição, território e patrimônio, confirmando a categoria território usada pela população indígena Krahô. ${ }^{18}$

18 “O que interessa discutir é, então, o território usado, sinônimo de espaço geográfico. E essa categoria, território usado aponta para a necessidade de um esforço destinado a analisar sistematicamente a constituição do território. Como se trata de uma proposta totalmente empiricizável, segue-se daí o enriquecimento da teoria." (SANTOS e SILVEIRA, 2001, p.20). 


\subsection{TERRITÓRIO E POPULAÇÃO INDÍGENA KRAHÔ}

De acordo com os estudos de Melatti (1970), a população indígena Krahô ${ }^{19}$ pertencente ao Tronco Lingüístico Macro Jê, Família Lingüística Jê, Língua Timbira e Dialeto Krahô - teve os primeiros contatos com os povos europeus no início do século XIX. O território por ela ocupado neste período tornou-se latifúndio para os criadores de gado, o que representaria um marco para os Krahô, que, a partir de então, passaram a se deslocar constantemente para outros territórios. Contudo, esta população indígena conservou a sua maneira tradicional de viver e seu sistema sócio-cultural por meio de rituais.

Desde o século XIX, portanto, os Krahô se viram forçados a praticar o deslocamento e a procurar novas terras, uma vez que foram obrigados a deixar a região próxima ao rio Balsas, na divisa dos Estados do Maranhão e Piauí. A história de ocupação do território atual dos Krahô é marcada por conflitos, perseguições e expulsões. Primeiro, deslocaram-se rumo ao oeste, partindo das proximidades da cidade de Carolina e seguindo o curso do rio Tocantins até Pedro Afonso; em seguida, se locomoveram mais a Noroeste, entre os rios Manoel Alves Pequeno e Vermelho, afluente do rio Manoel Alves Grande, região em que se encontram atualmente as dezoito (18) aldeias.

O território atual dos Krahô possui semelhanças com as terras do Sul do Maranhão e Piauí por também se localizar às margens de rios, o que contribuiu para que os rituais desta população não sofressem alterações. Os Krahô têm uma forte relação com a natureza, como é comum entre as populações indígenas de um modo geral. Para se alimentarem, coletam frutos silvestres, pescam, caçam, criam alguns animais domésticos e praticam a agricultura tradicional indígena. Segundo Melatti (1970, p.98):

\footnotetext{
19 “Os Krahó estão localizados num território de 3.200 kilômetros quadrados, entre os rios Manoel Alves Pequeno e o Vermelho (afluente do Manoel Alves Grande), da bacia do Tocantins, situado nos municípios de Goiatins (Piacá) e de Itacajá, ao norte do Estado de Goiás. Foi o Governo deste Estado que, pelo Decreto-lei n. ${ }^{\circ} 102$, de 5 de agosto de 1944, concedeu aos indígenas o uso e gozo das terras do referido território." (MELATTI, 1970, p.03). Com a criação do Estado do Tocantins, a partir da Constituição de 1988, o território indígena foi mantido, agora localizado no Estado do Tocantins
} 
A economia Krahô parece apoiada nas mesmas atividades que a caracterizavam antes do contato interétnico. Tais atividades, entretanto, sofreram modificações. A coleta, por exemplo, foi enriquecida com mangas e laranjas, frutas que podem ser encontradas em sítios abandonados pelos civilizados. A caça foi empobrecida pela redução da fauna, sem ter sido substituída pela pecuária.

Desde o século XIX, os Krahô vêm enfrentando conflitos com os fazendeiros, devido aos pequenos furtos de gado. Por várias vezes, os Krahô tentaram fazer sua própria criação de gado, mas não obtiveram sucesso. Até mesmo o antigo Serviço de Proteção ao Índio (extinto em 1967) e a atual FUNAI (criada em 1967) tentaram inserir na economia Krahô a pecuária, mas frustraram-se.

As mudanças que ocorreram entre os Krahô no que se refere às suas atividades, como a menor procura por frutos e a prática da caça fora das aldeias, estão relacionadas ao maior tempo de permanência na povoação. Entretanto, o território indígena Krahô é considerado a maior área contínua de cerrados conservados do Brasil, o que demonstra a relação da população indígena com a conservação do meio ambiente (fauna e flora).

Os Krahô compreendem que os não-indígenas são destruidores da natureza, justificando tal afirmativa ao declararem que estes derrubam todas as árvores para fazer plantio e, quando acabam com os recursos naturais, procuram outras áreas para iniciar novas destruições. Logicamente, as tendências apontam que as áreas de cerrados conservados ficarão restritas aos territórios indígenas e circundadas pela agricultura moderna e industrial. ${ }^{20}$

\footnotetext{
${ }^{20}$ Durante a realização do trabalho de campo em 2004, na aldeia Santa Cruz, Feliciano Tep Hot Krahô, um dos colaboradores e participantes desta pesquisa, comentou sobre o desmatamento das áreas de cerrados limítrofes ao território indígena Krahô, principalmente as áreas adquiridas pelos Gaúchos, Paulistas e Paranaenses, os quais estão preparando suas terras (desmatamento, aragem, construção de cercas, construção das sedes das fazendas) para o plantio de soja, milho, entre outros produtos alimentares que estão sendo inseridos nos solos dos cerrados.
} 
Como se sabe, a população indígena Krahô, que no início do século XIX foi estimada entre três (03) e quatro (04) mil índios, sofreu um decréscimo considerável na segunda metade deste mesmo século, quando foi novamente contabilizada, dessa vez registrando seiscentos e vinte (620) índios. Da metade do século XIX até os anos 1962-63, este número passou para quinhentos e dezenove (519). ${ }^{21}$ Dos anos 1960 até os nossos dias, em contrapartida, os Krahô têm aumentado a sua população, que soma, hoje, cerca de dois mil cento e vinte e nove (2.129) índios. O aumento deste contingente está associado aos avanços das pesquisas na medicina, à demarcação do território indígena Krahô, à sua organização política e à segurança alimentar, fatores que resultaram na melhora da qualidade de vida da comunidade. $^{22}$

No trabalho de pesquisa de campo realizado nos anos de 2004, 2005 e 2006, registrou-se que a agricultura tradicional Krahô desenvolveu-se consideravelmente. Todas as famílias gerais e individuais mantêm cultivos que são suficientes para satisfazer suas necessidades básicas. Vale ressaltar também que as aldeias contam com uma biodiversidade de árvores frutíferas, não sendo mais necessário coletar frutos nas propriedades dos sertanejos $^{23}$ vizinhos. Outro dado importante é a prática de criação de animais domésticos, que se apresenta ainda de forma muito precária. A caça e a pesca possuem relevância durante todo o ano, mas são realizadas com mais intensidade nos intervalos entre a preparação da terra e o plantio das sementes, que ocorrem entre os meses de agosto, setembro, outubro e novembro.

Os Krahô têm buscado alternativas para conseguir financiamentos junto ao governo federal, no intuito de estruturar a agricultura tradicional, gerar renda, melhorar a qualidade de vida e promover o desenvolvimento local e sustentável. Podem ser identificados como uma população indígena que, em troca do território que habitam, tem prestado serviços ambientais.

${ }^{21}$ GIRALDIN, O. Povos indígenas e não-indígenas: uma introdução à história das relações interétnicas no Tocantins. In: GIRALDIN, O. (Org.). A (trans)formação histórica do Tocantins. Goiânia: Ed. UFG; Palmas: Unitins, 2002. p.109-135.

${ }^{22}$ GUERRA, E. F. Organização política e segurança alimentar na sociedade Krahô. Dissertação (Mestrado em Geografia), Uberlândia - MG, UFU, 2004. Esta pesquisa contribui para compreender de forma analítica o atual quadro da organização política e da segurança alimentar em que se encontra a população indígena Krahô, contendo alguns mapas ilustrados, os quais foram disponibilizados gentilmente pelo autor para serem utilizados na presente pesquisa.

${ }^{23}$ Termo utilizado pela população indígena Krahô para se referir aos não-índios (KUPẼ) que habitam nas pequenas e médias propriedades próximas às áreas limítrofes do território indígena Krahô. 


\subsection{PATRIMÔNIO}

O termo patrimônio, quando vinculado às populações indígenas, possui um significado atrelado à tradição (costumes e hábitos) e também ao território ocupado. Nesse sentido, pode-se afirmar que as relações sociais e culturais estão fortemente relacionadas com o território. A distribuição da população indígena nas dezoito (18) aldeias, incluindo Kapey, forma o território Krahô, recebendo atribuição de território comum.

De acordo com o Artigo 216 da Constituição de 1988, o termo é assim definido:

Constituem patrimônio cultural brasileiro os bens de natureza material e imaterial, tomados individualmente ou em conjunto, portadores de referência à identidade, à ação, à memória dos diferentes grupos formadores da sociedade brasileira, nos quais se incluem: (EC nº 42/2003)

I- as formas de expressão;

II- os modos de criar, fazer e viver;

III- as criações científicas, artísticas e tecnológicas;

IV- as obras, objetos, documentos, edificações e demais espaços destinados às manifestações artístico-culturais;

V- os conjuntos urbanos e sítios de valor histórico, paisagístico, artístico, arqueológico, paleontógico, ecológico e científico. (CONSTITUIÇÃO DA REPÚBLICA FEDERATIVA DO BRASIL, 1988, p.124).

Rodrigues (2003, p.11-30), no artigo intitulado "Patrimônio, território e empreendedorismo: pilares do desenvolvimento com base local", faz referência ao termo Patrimônio, afirmando que neste se assenta e se solidifica o território, cujo quadro natural na sua componente paisagística é considerado patrimônio. 
Figura 02 - Terra Indígena Krahô, localização das aldeias e circulação

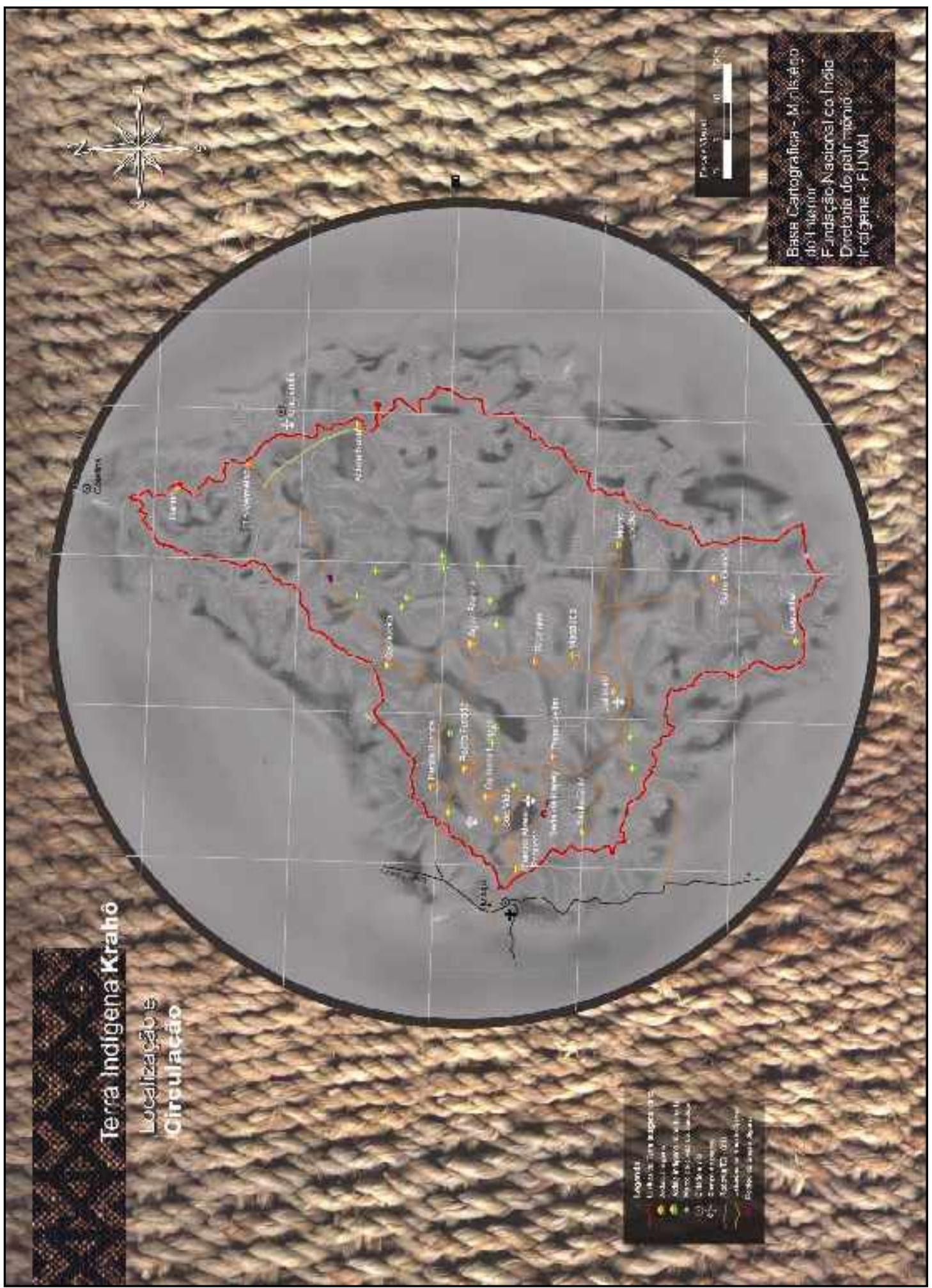

Fonte: Guerra, 2004. 
A arquitetura indígena e seu estilo marcam o histórico de vida dos Krahô. As paisagens, os personagens históricos, as tradições e a culinária também são seus fortes componentes simbólicos e contribuem para a ocorrência da manifestação do sentimento de povo e de nação, constituindo atribuições importantes e perspectivando a existência da memória e da identidade, que, quando relacionadas às das demais populações indígenas e nãoindígenas brasileiras, mostram-se diferentes.

De certa maneira, o patrimônio dos Krahô pode ser definido como o conjunto de bens (naturais e culturais) que estão dispostos no território por eles ocupado. Estes vínculos originários entre consciência mítica e território expressam-se nas relações com a natureza e com os elementos do universo. Por exemplo, a linguagem, os mitos, as histórias antigas, as cantigas antigas e os rituais manifestam valores culturais fortemente arraigados.

Obter-se-á uma compreensão mais exata do modo e do fundamento desta relação se neste estudo tornar-se possível remontar interpretações da força da tradição dos Krahô, a qual exige a reivindicação do território para fazer deste o seu patrimônio. Dentro do território acontece a tessitura do processo cultural, que comporta, por exemplo, relações de parentesco, estrutura social, vida social, língua própria, hábitos e costumes, rituais, enfim, todo tipo de manifestações culturais.

Cada aldeia tem um diretor de ritual. Na ausência deste faz-se o convite para um diretor de ritual de outra aldeia. Nas comunidades indígenas sempre há um membro que aprende com os mais velhos a realizar os diversos rituais. O diretor dos ritos também é cantador, conhecedor das tradições e do patrimônio, por isso pode tornar-se uma liderança política das comunidades indígenas. 
Vários são os grupos de rituais ${ }^{24}$, os quais têm como referência as metades Wakmeye e Katamye (metades sazonais), as metades Khöikateye e Harãkateye (metades de idade), as metades Khöirumpekëtxë e Harãrumpekëtxë, as metades Hëk e Krókrók e as metades Tép e Teré. $^{25}$

Os rituais possuem especificidades, havendo os que estão ligados ao ciclo de vida procriação, transmissão de nomes pessoais, de casamento, funerais, última refeição do morto e final do período de luto - e os que acentuam as relações entre consangüíneos e afins - Atam, Awriyé, Kuhiyarkwa, Rito da dádiva-agressão, Lua Nova, Meher’pïre, Péturé, Përekahëk, Meyen e Hamaho.

Há, ainda, os rituais do ciclo anual, como os do início da estação seca (Wakmeti, Apïnũré-Hokhiyere, Katamti, Róti, Rópyõpĩ, Apïnũré, Põhïyõkróu, Pẽnhok, Põhïpré, Põhïprï, Përteré, Txëikhré, Përti ou Yótyõpĩ e Katxëtkhrého), os ligados à iniciação (Ikréré, Pembkahëk $-1^{\circ}$ modalidade, Pembkahëk Hõpintohõ'txïre; $2^{\circ}$ modalidade, Pembkahëk Katuti; e $3^{\circ}$ modalidade, Pembkahëk Patxetïgré - Khöigayu, Piegré, Tépyarkwa, Kokritho, Rorot, Khetwaye - Khetwaye dos Kenpokráre, Khetwaye dos Mãkrare e o Khetwaye dos Apaniekrá - Witï, a investidura de Wïtï e a abdicação de Wïti) e, por último, os rituais de recepção de aldeias visitantes e de aclamação do chefe honorário.

Pode-se observar que existe um calendário de rituais, que foi desenvolvido com base no período anual e evidencia duas estações (seca e chuvosa), ficando a estação seca para a realização dos rituais ligados à iniciação. ${ }^{26}$

\footnotetext{
${ }^{24}$ Algumas considerações sobre Rito: "Tipo de cerimônia constituída por ações estandardizadas e ligada as fórmulas, gestos e símbolos, aos quais se atribuem virtudes ou poderes inerentes, suscetíveis de produzirem determinados efeitos ou resultados. O rito encontra-se não só na vida religiosa, mas em todas as esferas culturais de qualquer tipo de sociedade. Exemplos, casamentos são realizados através de ritos nupciais, tanto de caráter religioso, quanto civil. Uma série de gestos, falas e símbolos torna o casal unido perante a sociedade. O ritual do batismo é uma forma de agregar definitivamente o indivíduo à comunidade de fiéis. Ritos fúnebres expressam um procedimento que visa cortar vínculos com um estado anterior." (JUNQUEIRA, 2002, p.90).

25 "Os vários pares de metades em que se dividem os Krahó podem constituir uma transfiguração da oposição entre homens e mulheres ou entre consangüineos e afins, mas não se reduzem a isso, representando também a oposição entre as aldeias, entre vivos e mortos e uma série de outras oposições que lhes sugere uma visão de mundo. Cada par de metades deixa mais clara sua associação com certas oposições e mais obscura sua correspondência com outras." (MELATTI, 1978, p.354).

${ }^{26}$ Nota do próprio autor: "Os ritos do ciclo anual e os ligados à iniciação têm uma época prevista para serem realizados dentro do período anual. Nas duas faixas circulares mais externas, se concentram na estação chuvosa, enquanto a estação seca se reserva para a realização de um dos rituais ligados à iniciação." (MELATTI, 1978, p.355).
} 
Figura 03 - Os ritos do ciclo anual e os ligados à iniciação

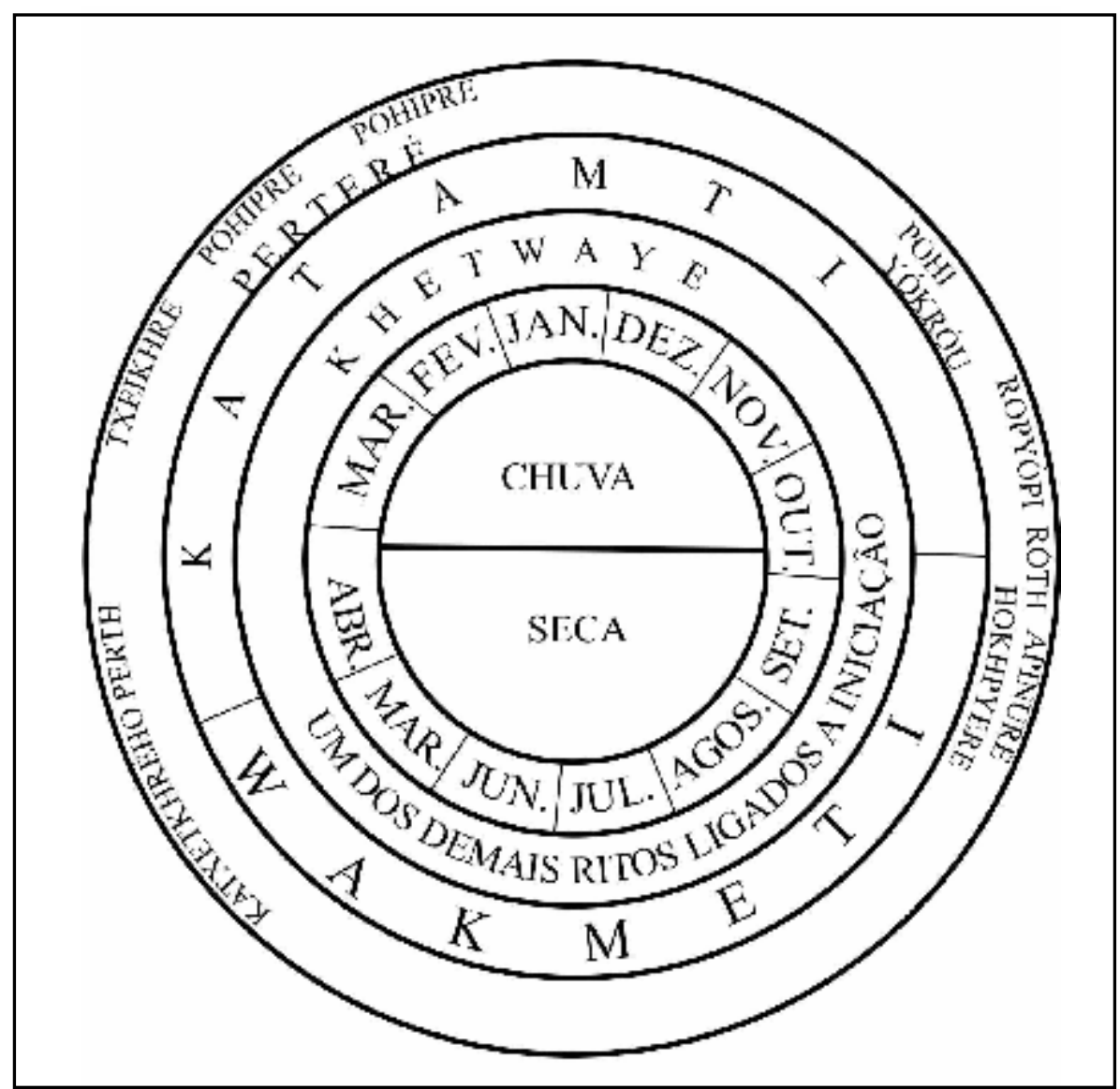

Fonte: Melatti, 1978, p.355.

Observa-se, ainda, que o sentimento de patrimônio extrapola a idéia de território, mas é imprescindível a existência deste para a sua valorização; ou seja, o patrimônio compõe o território numa relação dialética. Pode haver nesta relação o intuito de se compreender o território numa perspectiva integradora, conforme a proposição de Haesbaert (2004), discutida e analisada no primeiro capítulo.

O patrimônio natural, por sua vez, está relacionado aos recursos da natureza (fauna e flora). No território Krahô estão localizadas algumas das mais belas atrações naturais e culturais do país. Essa povoação é visitada com freqüência por turistas brasileiros e estrangeiros, os quais se interessam principalmente pelas seguintes atrações locais: vegetação de cerrados conservados, rios, mitos, histórias antigas, cantorias, rituais, diversidade cultural e artesanato, entre outras. Entretanto, o que potencializa o turismo da região é a própria população indígena Krahô e o seu território. Nesse sentido, vale ressaltar que os Krahô estão 
inseridos num processo de mudanças culturais e, por isso, podem ser considerados portadores de uma identidade étnica em construção.

A construção do patrimônio cultural acontece no processo contínuo de transformação entre passado e presente, mantendo "invariabilidade". Nessa tessitura vão sendo criadas as noções imbricadas de identificações culturais. Uma forma de se valorizar o passado no presente, isto é, de se lembrar do que foi "esquecido", é a realização dos rituais. As novas gerações possuem estas necessidades para reforçar o sentimento de identidade.

O patrimônio dos Krahô pode ser analisado e identificado como valorização da cultura, como desenvolvimento de atividades econômicas sustentáveis e como proteção do território. Assim, pode-se dizer que as atividades turísticas com base local têm aí as suas principais vantagens comparativas e competitivas.

\subsection{DIVERSIDADE CULTURAL E POVOS INDÍGENAS}

A compreensão das culturas humanas perpassa pelo entendimento da complexidade dos estudos das diferentes culturas. E a compreensão acerca da diversidade cultural das populações indígenas torna-se difícil, pois é impossível chegar a conhecer a sua riqueza por completo.

Lévi-Strauss (1970, p.231-270) argumenta que "Para compreender como, e em que medida, as culturas humanas diferem entre si, se essas diferenças se anulam ou se contradizem, ou se concorrem para formar um conjunto harmonioso, é necessário tentar fazerlhe um inventário" (LÉVI-STRAUSS, 1970, p.233). Segundo este autor, esta é a grande dificuldade, pois as culturas humanas não diferem entre si da mesma maneira nem no mesmo plano. Contudo, as sociedades estão localizadas espacialmente próximas ou distantes umas das outras, mas num mesmo contexto histórico e espacial, de modo que o que impera é a contemporaneidade.

Nesta perspectiva, não é possível conhecer com profundidade as diferentes sociedades, já que muitas não são mais existentes, mas deixaram registros relevantes que contribuem para a construção de hipóteses de como elas eram no passado. Neste caso, portanto, o contato pode ser realizado apenas de forma indireta. Sendo assim, "Uma constatação se impõe: a diversidade das culturas humanas é de fato no presente, de fato e 
também de direito no passado, muito maior e mais rica que tudo o que estamos destinados a conhecer a seu respeito" (LÉVI-STRAUSS, 1970, p.234). Assim, pode-se considerar que há uma estreita proximidade entre diversidade cultural e história da humanidade, bem como que a reunião da história das diferentes sociedades localizadas num tempo e espaço específicos assegura as diferenças e mantém de forma marcante as fronteiras entre os grupos sociais. Nesta lógica, a proposição levantada pelo autor, "O que se entende por culturas diferentes?", ainda pode ser objeto de muitas especulações de idéias. ${ }^{27}$

Portanto, nos territórios nacionais estão presentes as suas diversidades culturais. Entre as suas formas de expressão se encontra o estudo da linguagem, tomando-se como referência o número de línguas que são faladas em todo o mundo, onde a distância e a proximidade espaciais revelam as acentuadas diferenças, mas tendo um único objetivo, a comunicação interna e/ou externa dos diferentes grupos sociais. No que diz respeito aos povos indígenas brasileiros, Rodrigues (2002, p.17) afirma:

Os índios do Brasil não são um povo: são muitos povos, diferentes de nós e diferentes entre si. Cada qual tem usos e costumes próprios, com habilidades tecnológicas, atitudes estéticas, crenças religiosas, organização social e filosofia peculiares, resultados de experiências de vida acumuladas e desenvolvidas em milhares de anos. E distinguem também de nós e entre si por falarem diferentes línguas.

Compreende-se, assim, que cada sociedade possui os seus elementos significativos, os quais compõem a sua identidade.

Parece que a diversidade das culturas e a história da humanidade são marcadas por conflitos. Grupos étnicos estabelecem recontros no interior de suas fronteiras, levando uns e

27 "Algumas parecem sê-lo, mas, se nascem de um tronco comum, não diferem tanto quanto duas sociedades que em nenhum momento de seu desenvolvimento mantiveram relações. Assim, o antigo império dos Incas do Peru e o do Daomé na África diferem entre si de maneira mais absoluta do que, digamos, a Inglaterra e os Estados Unidos de hoje, ainda que essas duas sociedades também devam ser tratadas como sociedades distintas. Inversamente, sociedades que recentemente entraram em contato bastante íntimo parecem oferecer a imagem da mesma civilização, quando chegaram até aí por caminhos diferentes, que não temos o direito de desprezar. Há ao mesmo tempo, nas sociedades humanas, fôrças que trabalham em direções opostas: umas tendem à manutenção e ao mesmo aguçamento dos particularismos; outras agem no sentido da convergência e da afinidade [...]." (LÉVISTRAUSS, 1970, p.234). 
outros a se reafirmarem em novos contextos, todos compartilhando a diversidade cultural em suas complexidades. $^{28}$

Outra atribuição que está vinculada à diversidade das culturas é a sua dinâmica. Em momento algum da história da humanidade foi permitido o isolamento, ou seja, as "sociedades humanas nunca estão sozinhas; quando aparecem as mais separadas, é ainda a forma de grupos ou de ajustamentos" (LÉVI-STRAUSS, 1970, p.235). Seguir os fios dos acontecimentos parece ser o destino infinito e sem retorno do ser humano; estes fios estão embaraçados na diversidade cultural e na história da humanidade.

Assim, não é exagero supor que as culturas norte-americanas e sul-americanas estiveram separadas de quase todo o contato com o resto do mundo durante um período cuja a duração se situa entre dez e vinte cinco mil anos. Mas esse grande fragmento humano isolado consistia numa multidão de sociedade, grandes pequenas, que mantinham entre si contatos muito estreitos. (LÉVI-STRAUSS, 1970, p.235).

Neste sentido, pode-se supor que o isolamento em nenhum momento da história foi o objetivo mais perseguido pelas diferentes sociedades, e sim os contatos culturais. Nesta mesma lógica, o autor considera:

E, ao lado das diferenças causadas pelo isolamento, há aquelas igualmente importantes, devidas à proximidade: desejo de opor-se, de distinguir-se, de ser ele próprio. Muitos costumes nasceram, não de qualquer necessidade interna ou acidente favorável, mas apenas da vontade de não continuar devedor a um grupo vizinho que tinha um uso preciso para um domínio em que ele próprio não sonhara ditar regras. Conseqüentemente, a diversidade das culturas humanas não nos deve convidar a uma observação fragmentadora ou fragmentada. Ela é menos função de isolamento dos grupos que das relações que as unem. (LÉVI-STRAUSS, 1970, p.235-236).

28 "Como todas as demais, as línguas indígenas do Brasil são inteiramente adequadas à plena expressão individual e social no meio físico e social em que tradicionalmente têm vivido esses povos. Embora, diferentes, elas compartilham do que todas as quase seis mil línguas do mundo têm em comum: são manifestações da mesma capacidade de comunicar-se pela linguagem. Essa capacidade é uma qualidade desenvolvida pela espécie humana e se caracteriza por princípios e propriedades que, presentes em todo homem, facultam a qualquer criança desenvolver o domínio de qualquer língua, sempre que exposta ao contato com falantes dessa língua. Da mesma forma, permitem a qualquer adulto, com maior ou menor esforço, aprender línguas diferentes da sua própria." (RODRIGUES, 2002, p.17). 
A diversidade cultural amplia o leque das diferenças, e estas compõem a história da humanidade no contexto das relações entre as distintas sociedades humanas. Num sentido mais concreto, a diversidade cultural pode ser considerada relevante do ponto de visto da organização do turismo ao redor do mundo, pois os turistas buscam realizar viagens para diversas localidades, associando a prática do lazer e do turismo em locais onde pode ser possível realizar contatos diretos (populações autóctones) e indiretos (templos antigos) com as diferentes culturas.

\subsubsection{Relações entre as culturas e mudanças culturais}

A noção de cultura nas Ciências Sociais pode contribuir para a construção da análise das culturas singulares e dos princípios universais da cultura, embora ainda não haja um campo de pesquisa próprio para se aprofundar as investigações teórico-metodológicas sobre a aculturação. Os contatos culturais entre as populações indígenas e não-indígenas são os principais causadores do processo de aculturação, mas ainda não dispõem de reflexões precisas que permitam propor um entendimento particular e universal.

Em função da imensa quantidade de contatos culturais que estão sendo estabelecidos entre povos diferentes e de lugares distintos, aumentaram as dificuldades para se propor uma explicação menos embaraçosa acerca da aculturação. Neste aspecto, "Os antropólogos difusionistas se interessaram bastante pelos fenômenos dos empréstimos e da repartição dos 'traços' culturais a partir de um suposto 'lar' cultural. Mas seus trabalhos tratavam do resultado da difusão cultural e descreviam somente um sentido único" (CUCHE, 2002, p.109).

Segundo Cuche (2002), não há um sentido único quando se trata de cultura, e a difusão entendida desta forma não confronta "a cultura que recebia e a cultura que dava", de modo que existe um maior acúmulo de estudos sobre culturas singulares do que a relação destes estudos com os "entrecruzamentos das culturas". "Os etnólogos cederam por muito tempo ao que se denomina a 'superstição do primitivo' ou ainda o 'mito do primitivo'." (CUCHE, 2002, p.110). De acordo com o pensamento do autor, as práticas dos etnólogos contribuíram para o acirramento da atual crise, pois admitiam que "as formas elementares da 
vida social e cultural" apresentariam questionamentos novos e estes seriam criados ao passo que a sociedade contemporânea apresentaria as suas diversas formas de desenvolvimento.

Todavia, para compreender a complexidade da sociedade contemporânea faz-se necessário iniciar pelo estudo da cultura. As culturas primitivas eram compreendidas como culturas autênticas, pouco ou não modificadas pelo contato com as outras culturas. "A etnologia não somente cultivou a obsessão da busca do aspecto original de cada cultura, mas também a da procura do caráter absolutamente original de cada cultura" (CUCHE, 2002, p.111). Ainda segundo Cuche, já vinha ocorrendo um processo de mestiçagem das culturas, inserindo modificações na pureza original, o que deixava os pesquisadores incomodados e sem pistas.

A teoria da aculturação é entendida como uma noção originada de certas questões do culturalismo americano, pois ainda conserva os mesmos impasses existentes no culturalismo, que enfatiza os traços culturais. Nesse sentido:

Como toda cultura é um todo, um sistema. Como toda cultura é uma unidade organizada e estruturada, na qual todos os elementos são interdependentes, é ilusório pretender selecionar os aspectos supostamente "positivos" de uma cultura para combiná-los com os aspectos "positivos" de uma outra com o objetivo de chegar assim a um sistema cultural "melhor", como pretendia um certo humanismo. (CUCHE, 2002, p.120).

Esta proposição, quando colocada em prática, pode acentuar os conflitos entre grupos sociais diferentes e torna-se uma "prática irrealizável".

Num mesmo país pode existir uma diversidade de culturas, proveniente da existência de grupos sociais diferentes, sendo que os contatos culturais entre tais grupos podem modificá-los. No entanto, de certa maneira, existe uma resistência cultural entre os diferentes grupos.

Calcula-se que a população indígena no Brasil esteja em torno de 310 mil indivíduos, dos quais 280 mil vivem em terras indígenas. Embora essa população seja relativamente pequena, é riquíssima em diversidade social. Há 206 sociedades indígenas - 160 das quais estão na Amazônia - e aproximadamente 195 línguas diferentes. Estima-se que haja ainda 50 grupos indígenas arredios e sem contato regular com o mundo exterior. (CUNHA e ALMEIDA, 2001, p.187). 
A Reserva Indígena de Dourados, localizada no estado do Mato Grosso do Sul, pode ser considerada um exemplo da tentativa de se combinar aspectos culturais entendidos como positivos, no intuito de se introduzir um sistema cultural melhor e que pudesse beneficiar todas as etnias. Entretanto, os dois subgrupos Guaranis entraram em conflito com os Terenas, confirmando o equívoco das estratégias dos colonizadores. Sobre esse assunto, Cabreira e Moretti dizem:

Os Terenas, por sua vez, são do tronco lingüístico Aruak e não eram, originalmente, habitantes destas terras. Eles foram trazidos pelo Serviço de Proteção ao Índio (SPI), com a finalidade de ensinarem aos indígenas da Reserva, um novo sistema de manejo do solo e facilitar o contato e a integração com a sociedade nacional. Isso aconteceu, por terem, os Terenas, uma maior habilidade no cultivo e por aceitarem mais facilmente o sistema do não-índio. O Contato dessas etnias, acreditava os colonizadores, iria facilitar a integração dos indígenas à comunhão nacional, isto é, às regras do jogo capitalista. (CABREIRA e MORETTI, 2005, p.2544).

Depois do fracasso da tentativa de colocar populações indígenas diferentes num mesmo território, os Terenas, que chegaram à área por intermédio do SPI, foram obrigados a definir sua territorialidade, como é o caso da Reserva Jaguapiru, ficando distantes dos Bororos, dos Guaranis e dos Kaiwás. Com isso, tornaram-se mais dependentes do consumo de produtos industrializados e, por conseguinte, viram-se obrigados a efetuar compras nos núcleos urbanos próximos, o que acentuou ainda mais a crise deste povoado, pois, de certa maneira, a falta de renda para o índio limitou o seu poder de compra no mercado.

Nesta mesma lógica,

Atualmente, considera-se principalmente, as transformações de ordem simbólica decorrentes do contato com teorias de mundo diferentes. Desta forma, pode-se compreender não apenas o impacto das atividades econômicas, mas o impacto das idéias que englobam a compreensão destas atividades. Com esta perspectiva, estudos recentes comparam, por exemplo, grupos tão distantes e diferentes como os Bororo (povo MacroJê do Mato Grosso) e os grupos do alto Rio Negro (de fala Tukano, principalmente), levando em conta o longo trabalho missionário realizado pela ordem católica dos Salesianos entre estes povos. A comparação pode revelar que, apesar de sujeitos a uma doutrinação idêntica, cada povo a interpretou de uma maneira, a partir das idéias próprias de suas culturas. (TASSINARI, 1995, p.472). 
De acordo com as reflexões da autora, a diversidade cultural entre os índios pode ser compreendida a partir da idéia de dinâmica cultural. Ou seja:

Cada cultura indígena nos apresenta a atualização de uma tradição ancestral, compartilhada pelos demais membros de sua família lingüística. Cada lugar indígena apresenta também uma versão própria das idéias e dos costumes conhecidos através do contato com outras populações. (TASSINARI, 1995, p.472).

Compreende-se também que no contato entre os índios e destes com a sociedade nãoindígena todos mudaram, cada etnia à sua maneira, cada sociedade à sua maneira. Nesta perspectiva, toda a humanidade mudou, mas o convívio com as diferenças ainda pode ser considerado o conteúdo mais expressivo na diversidade cultural.

O turismo tem sido analisado na ótica das relações entre as diferentes culturas, o que permite identificar os pontos positivos e negativos das atividades turísticas que envolvem populações diferentes. De acordo com as abordagens propostas pelos autores, não se pode afirmar que as relações entre as culturas provocam mudanças culturais apenas no sentido negativo. Ainda conforme tais abordagens, se deve evitar o uso dos conceitos de cultura em que se fundamentam as interpretações culturais românticas. Entretanto, do ponto de vista cultural, não existe o grupo social forte nem o grupo social fraco, embora tais interpretações ainda sejam bastante usuais nos estudos sobre o turismo, principalmente quando se referem às populações autóctones.

A seguir, realiza-se a análise do termo desenvolvimento, o que permite compreender a lógica do desenvolvimento com base local.

\subsection{O DESENVOLVIMENTO COM BASE LOCAL}

Em planos mais profundos, a palavra desenvolvimento, buscando-se pressupostos teóricos e metodológicos, possui um significado que coloca em evidência o uso do próprio termo desenvolvimento. Nesse sentido, a palavra desenvolvimento: 
[...] por si só, já é prenhe de juízos de valor, antes mesmo de alguém qualificar o que entende pelo termo. Afinal, as sociedades tribais, ditas também 'frias' ou (muito impropriamente) "sem história", não se colocam a questão de um "desenvolvimento", como toda tarefa consciente ou desafio. (SOUZA, 1996, p.05).

De acordo com o pensamento do autor, deve-se destacar o sentido que o termo desenvolvimento adquiriu durante o século XX, principalmente no conjunto de ideologias das escolas acadêmicas que estão sempre propondo novos modelos de desenvolvimento para justificar as estratégias de crescimento econômico, de cunho capitalista, relacionado às mudanças e transformações. Pode-se afirmar que é a negação da condição anterior, perspectivando novas condições econômicas, sociais, políticas, culturais e ambientais. Dessa forma, "O solo cultural onde a idéia de desenvolvimento se enraíza é, por excelência, a modernidade, que por sua vez é uma cria dessa entidade histórico-geográfica chamada Ocidente" (SOUZA, 1996, p.05).

Analisando as reflexões do referido autor, pode-se perceber que o termo desenvolvimento é visto a partir da análise dos princípios éticos e político-filosóficos no histórico do capitalismo, demonstrando justamente a ansiedade pelo progresso, chegando a ponto de confrontar ideologias e posições políticas explícitas, como, por exemplo, entre marxistas e filósofos burgueses, aprofundando o projeto da modernidade e de seus valores. Entende-se, assim, que o termo desenvolvimento adquiriu um sentido ambíguo ou pouco confiável, devido às contradições sociais que foram criadas durante o desenrolar do sistema econômico capitalista. Nessa perspectiva, ao se fazer uma leitura do termo desenvolvimento como um projeto da modernidade não resta muitas expectativas, pois o levante das contradições torna-se mais contundente.

De certa maneira, os pós-modernos inauguraram um novo debate que propôs a ruptura das correntes de pensamento anteriores e, em específico, da modernidade. $\mathrm{O}$ discurso da modernidade pode ser compreendido como carregado mais de instrumentos da opressão do indivíduo do que da sua libertação. No discurso dos pós-modernos, a própria idéia de verdade passou por um processo de desintegração, constituindo proposições que negaram a verdade absoluta.

As indagações propostas como abertura para a discussão sobre o desenvolvimento entendido como um discurso da modernidade evidenciam inúmeras críticas, as quais podem ser percebidas no ensaio de Souza (1996, p.05-22). Contudo, parece que o intuito das 
reflexões do autor tem sido arrancar uma nova posição libertária do conjunto das proposições que foram formalizadas. Entre elas, uma merece destaque, especialmente as posições de Kaplan (1993), que foi mencionado no supracitado ensaio como um ponderador dos discursos do pós-modernismo, apresentando uma proposta epistemológica e metodológica específica para a temática. A proposição que está colocada no ensaio destaca a idéia de desenvolvimento. Por um lado, deve-se evitar um termo conceito e, por outro, está explícita a negação de um conceito unívoco de desenvolvimento.

Nesse sentido, o autor propõe uma leitura analítico-crítica quando se refere aos novos rótulos que estão impregnados no termo desenvolvimento e que perpassam por variados enfoques, entre os quais: satisfação das necessidades básicas, desenvolvimento sustentável e, por último, transformação produtiva com equidade. Depois de enfatizar estes novos rótulos, o autor apresenta propostas de descentralização teórica e evidencia a necessidade de se formular uma teoria aberta para se avançar nas reflexões sobre o desenvolvimento.

Portanto, está exposto o caminho para a construção de uma análise do termo desenvolvimento numa perspectiva teórica e metodológica aberta, o que permite acrescentar novos termos, entre os quais autonomia e liberdade. O senso comum possui uma validade, se o desejo do pesquisador for o de romper com as posturas autoritárias do cientificismo. Ao que parece, Souza (1996) tem uma proposta para desmantelar o termo desenvolvimento, principalmente a essência em que a sua forma foi propagada como tentativa da ocidentalização do mundo. A participação das coletividades insere novas atribuições para o pesquisador, isto é, de pesquisador para interlocutor.

Nesse sentido, ao invés de se pensar no desenvolvimento, deve-se construir reflexões sobre o desenvolvimento sócio-espacial. Tendo em vista o exposto:

O que ocorre, por conseguinte, é uma subversão geral da própria forma convencional de se fazer ciência ("pura" ou "aplicada"), de se refletir sobre o desenvolvimento - sem, contudo, ceder à tentação fácil de banimento da razão e do projeto de modernidade, autocrítica essa que busca ultrapassar dialeticamente tanto a razão instrumental quanto a sua negação simplista, o niilismo "pós-moderno". (SOUZA, 1996, p.19). 
Assim, o termo utilizado pelo autor, desenvolvimento sócio-espacial, leva em consideração a localidade em que está acontecendo na prática.

Possivelmente, o indicador da direção do homem do futuro está relacionado às ações da localidade e da globalidade, modo pelo qual o turismo tornou-se um fenômeno global. ${ }^{29}$ Por isso, se pode considerar a pergunta endereçada aos estudiosos do turismo, como, por exemplo: Como pode o turismo contribuir com o desenvolvimento local $?^{30}$ Aliás, esta questão foi colocada como um problema central desta pesquisa e deverá permanecer em aberto até o seu final, pois se pode identificar a complexidade dos termos turismo e desenvolvimento com base local, que foram colocados nos entrecruzamentos teóricos e metodológicos.

Das nuances da realidade do paradigma entre o turismo e o propósito do desenvolvimento local que se construiu a análise das contribuições do turismo para promover o desenvolvimento local. No subitem que se segue, são apresentadas considerações sobre as contribuições do turismo para o desenvolvimento local.

29 “O ser humano consegue tornar-se onipresente - além de estar em vários lugares ao mesmo tempo, pode interagir simultaneamente com o passado, com o presente, com o futuro. Porém, os efeitos perversos do mundo globalizado virtual, paradoxalmente doméstico, conduzem a humanidade à solidão. Vivemos, assim, a era do simulacro, confundindo ficção com realidade. A violência exibida diariamente ao vivo pela televisão juntamente com filmes do mesmo teor colocam realidade e ficção no mesmo nível, confundindo os espectadores - crianças, jovens e até mesmo os adultos. O Ávido consumo dos produtos do turismo e do lazer relaciona-se diretamente ao número de habitantes residentes em centros urbanos, não só porque constituem um volume maior, mas também, e principalmente, pela ideologia do hedonismo consumista, que é largamente difundida pela mídia, tornando-se uma das características das sociedades pós-industriais." (RODRIGUES, 2001, p.91-92).

${ }^{30}$ Nesta lógica, os Encontros Nacionais de Turismo com Base Local reúnem um conjunto de reflexões sobre a temática turismo e desenvolvimento com base local. Este evento pode ser considerado o mais relevante de todos os realizados no Brasil sobre o turismo, pois integra profissionais de diversas áreas do conhecimento, perspectivando assegurar o compromisso com as teorias e com a multidisciplinaridade. Por seu turno, os ENTBL's se encontram na nona versão, isto é, o $I E N T B L$ foi realizado em 1997, pelo Departamento de Geografia da FFLCH-USP, sob a Coordenação da Profa. Dra. Adyr Balastreri Rodrigues. O IX Encontro Nacional de Turismo com Base Local foi realizado entre os dias 10 e 13 de novembro de 2005, na cidade de Recife-PE. Do I ENTBL até o IX ENTBL foi mantido um intervalo de um (01) ano, de modo que se decidiu em plenária final do $I X E N T B L$ que a partir do $X E N T B L$ será realizado com um intervalo de dois (02) anos. Como se sabe, a realização deste evento é de suma importância para aprofundar os debates teóricos e metodológicos. Por um lado, se pode registrar a falta de apoio por parte dos órgãos financiadores no âmbito do governo federal e, por outro, se pode afirmar o compromisso dos profissionais que estão envolvidos na organização dos ENTBL's, desde os proponentes do Evento aos que ingressaram nas discussões mais tardiamente. Enfim, mesmo com os obstáculos colocados pelos órgãos públicos federais, se pode afirmar que novas versões dos $E N T B L$ 's continuarão sendo organizadas. 


\subsection{CONTRIBUIÇÕES DO TURISMO PARA O DESENVOLVIMENTO LOCAL}

Atualmente, a mobilidade do homem constitui-se numa regra; ou seja, seus deslocamentos de um lugar para outro são freqüentes, na condição de turistas e/ou de imigrantes, o que enriquece as relações de proximidade e produzem a alteridade e a comunicação. Revela-se, assim, a sociabilidade do lugar e no lugar, resultado da proximidade ou da distância espacial, incrementada com a contigüidade física entre as pessoas numa mesma extensão, num mesmo conjunto de pontos contínuos, que vivem nesta lógica com a intensidade de suas relações um conteúdo comunicacional que está fortemente relacionado com a modernidade.

Desta maneira, no intuito de se contribuir para as discussões sobre o turismo e a modernidade, além da referência ao pensamento de Milton Santos (2002), menciona-se algumas reflexões em que os autores colocam as suas proposições analíticas sobre o turismo e o desenvolvimento local.

Souza (1997, p.17-22), no seu artigo intitulado "Como pode o turismo contribuir para o desenvolvimento local?", argumenta que a literatura sobre o desenvolvimento e o turismo local pode ser considerada recente. O turismo teve a sua expansão a partir da Segunda Guerra Mundial, mas foi um turismo de massa que ocorreu dentro de uma lógica de importância diferenciada em diversos países, regiões e cidades. Ainda hoje se pode entender o turismo como uma relevante atividade econômica que provoca impactos sociais e ambientais e que, por isso, exige reflexões no tratamento teórico e metodológico, assim como o desenvolvimento local, para ser possível elencar as contradições e procurar meios de minimizá-las. De modo geral, "cada situação concreta acarretará uma interpretação e um julgamento diferentes" (SOUZA, 1997, p.19).

Nesse sentido, deve-se levar em conta três grupos principais de indivíduos. Em primeiro lugar, a população da área de origem dos turistas, que não ganha nem perde, uma vez que, procurando novos destinos turísticos fora de sua área de origem, pode evitar impactos sociais e ambientais em seu território. Em segundo lugar, os turistas que podem ganhar com o turismo, principalmente quando viajam para lugares que correspondem às expectativas esperadas. E em terceiro lugar, a população da área de destino dos turistas, que possui particularidades, assim como a população da área de origem dos turistas. 
As dessemelhanças são maiores quando envolvem populações de primeiro mundo e de terceiro mundo. O risco que faria lograr para a área de destino dos turistas em que:

[...] a consideração da escala local (sem esquecer, é lógico, a contribuição de processos que emergem e operam em outros níveis) é, a esse respeito, esclarecedora, pois quanto mais frágil econômica e politicamente é um grupo, maior tende a ser a sua dependência para com recursos de base estritamente local. (SOUZA, 1997, p.20).

Para avançar na discussão, o autor apresenta dois destaques: a questão da autonomia das coletividades; e a existência de graus de complexidade diferentes. Quando se refere à questão da autonomia, Souza analisa o turismo na perspectiva do desenvolvimento sócioespacial, afirmando que as comunidades locais (às quais o autor se refere como coletividades) são as responsáveis por gerir os seus destinos e que o turismo pode ser considerado uma atividade econômica importante, mas que deve ser disciplinada a partir das necessidades colocadas pelas comunidades locais. Já se referindo à existência de graus de complexidade diferentes, Souza afirma que quando envolve grupos sociais com poder aquisitivo semelhante pode-se ter um quadro que traz benefícios para os referidos grupos. Numa outra situação, no entanto, envolvendo grupos sociais diferentes do ponto de vista econômico, o grupo social com maior poder de compra pode prejudicar o grupo mais pobre.

No que diz respeito a...

[...] esse turismo, sócio-espacialmente [...]; do ponto de vista do desenvolvimento, dependendo: 1) do que se entenda por desenvolvimento; 2) da natureza do turismo em questão $[\ldots]$; 3) de quais grupos sociais ou segmentos sociais específicos referentes à área de destino do fluxo turísticos se esteja falando. (SOUZA, 1997, p.21).

Portanto, parece que não existe uma resposta universal quanto às contribuições do turismo para o desenvolvimento local; contudo, se pode pensar no turismo como um fator de desenvolvimento sócio-espacial.

Rodrigues (1997, p.55-64), por sua vez, afirma que para se refletir sobre o turismo na perspectiva econômica faz-se necessário considerar o papel da Organização Mundial do Comércio, já que o turismo tem recebido a atribuição de primeiro produto do comércio planetário. A Organização Mundial do Turismo destaca-se por exercer a função de sistematizar e controlar as informações sobre o turismo como uma importante atividade econômica, disponibilizando dados sobre as tendências recentes dos fluxos turísticos 
mundiais. É, portanto, uma fonte que pode influenciar as políticas de turismo, que, “estabelecidas no bojo das instituições nacionais, são sempre orquestradas pela política econômica vigente, hoje macro-escala, com vistas ao mercado global" (RODRIGUES, 1997, p.56). Ainda segundo Rodrigues, tais políticas econômicas desconsideram as características dos lugares, contemplado apenas as políticas das elites hegemônicas do capitalismo mundial.

Neste aspecto, cada país apresenta os seus elementos conjunturais de inserção social no mundo globalizado. Do ponto de vista do mundo do trabalho, as perspectivas não são nada promissoras. $^{31}$ Isto se torna mais claro intercalando-se as discussões entre os termos globalização e lugar: "Na contracorrente da globalização (perversa ou não), de repente, o lugar aparece com toda sua força, porque é nos fragmentos que se assenta o global." (RODRIGUES, 1997, p.58). Assim, o lugar pode ser considerado um ponto fundamental de reflexão para os estudiosos do turismo, uma vez que este possui uma estreita relação com os lugares. Por isso a valorização dos lugares ganhou uma grande dimensão nas últimas décadas, uma vez que refletir sobre esse assunto é pensar também na valorização cultural.

Deter-se no lugar significa abandonar a crença predominante nas soluções pretensamente universais e opor-se a fórmulas externas. Há que confiar na capacidade e sabedoria das comunidades locais na identificação dos seus problemas e na tentativa de soluções originais, com base na sua própria experiência e na de outros grupos similares. (RODRIGUES, 1997, p.58).

Por um lado, a transferência de tecnologia dos países centrais para os países pobres pode ser considerada um aspecto positivo e, por outro, a busca de soluções alternativas pode contribuir para a conservação dos lugares, causando menos impactos sócio-espaciais. Para isto, as tecnologias a serem importadas deverão passar por uma rigorosa investigação, sendo submetidas a adequações de acordo com as especificidades dos lugares em que serão introduzidas. Por isso, a revelação do lugar aparece como uma contraposição à racionalidade hegemônica da globalização; ou seja, o desenvolvimento com base local contrapõe o processo de globalização. Essa concepção de desenvolvimento pode ser apreendida como a

\footnotetext{
31 “Tudo evidência que na era da reestruturação produtiva, da flexibilização e da desregulamentação, a 'classe' que vive do trabalho encontra-se mais fragmentada, mas complexificada, mais heterogeneizada. Divide-se entre qualificados e desqualificados, estáveis e precários, nacionais e imigrantes, brancos e negros, inseridos e excluídos, sem contar com as divisões que decorrem da inserção diferenciada dos países e de seus trabalhadores na nova divisão internacional do trabalho." (RODRIGUES, 1997, p.57).
} 
materialização do desenvolvimento sócio-espacial em que os países centrais do capitalismo impõem a lógica do consumo para as sociedades dos países periféricos.

De acordo com as reflexões da autora, as discussões mais recentes sobre o desenvolvimento perpassam pela fórmula do desenvolvimento em escala humana, isto é, as necessidades humanas não podem ser esquecidas, pelo contrário, devem ser levadas em conta do início ao final do processo de desenvolvimento. As estratégias de desenvolvimento podem deixar de causar uma impressão confusa se considerarem a geração de satisfação sinergética como princípio no decorrer do processo de mudança e de transformação. Há, portanto, uma enorme quantidade de debates possíveis sobre o desenvolvimento.

Pode-se dizer que o turismo interno no Brasil tem a possibilidade de apresentar novas oportunidades, entre elas a inversão dos gastos de turistas brasileiros no exterior, que têm apresentado um consumo maior do que aquele referente aos turistas estrangeiros no Brasil.

Daí a necessidade de dar-se mais incentivo ao turismo interno no Brasil, que nunca mereceu muito destaque na Política Nacional de Turismo, em que a tendência é contemplar o turismo internacional através de incentivo aos mega-empreendimentos financiados por firmas multinacionais. (RODRIGUES, 1997, p.59-60).

Fazendo referência aos destaques apontados pela autora, evidencia-se a quase ausência de incentivos para aumentar a demanda do turismo interno no Brasil, sobretudo se consideradas as políticas internacionais praticadas pelos países conhecidos por fazerem investimentos neste setor. Estes, ao contrário do Brasil, direcionam um grande volume de capital para atrair e despertar os turistas interessados em conhecer o exterior, o que permite obter o retorno econômico sob a forma de lucro a partir do turismo.

De acordo com a análise da autora:

Podemos lançar mão de vários dados para estimar a demanda de turismo interno no Brasil.

1) pelo efetivo das classes $A, B$, e $C$ (sem considerar a $D$, consumidores emergentes), que é de quase 50 milhões de pessoas;

2) pelo faturamento anual do turismo brasileiro, estimado em 45 bilhões de dólares, sendo que somente 2 bilhões correspondem ao turismo receptivo internacional;

3) pela saída de turistas brasileiros para o exterior, calcula-se em 4 milhões/ano. Para cada turista que sai, calcula-se 10 para o turismo interno. (RODRIGUES, 1997, p.60). 
É preciso também reconhecer que "o caminho a seguir é um incentivo ao crescimento do turismo doméstico no Brasil, um turismo que ofereça alternativas também para as classes emergentes, portanto, um turismo que dinamize os recursos locais e regionais, enfim um turismo com base local" (RODRIGUES, 1997, p.60). Este turismo doméstico está relacionado ao que já vem sendo praticado por inúmeros grupos de turistas e que pode ser considerado em suas modalidades, entre as quais: ecoturismo; turismo de saúde; turismo rural; turismo urbano; e turismo religioso, entre outras.

Nesse sentido, percebe-se que os turistas fortemente dominados por um determinado interesse acabam exigindo projetos alternativos de turismo. Os benefícios do turismo com base local estão articulados com o aumento da renda local, via prestação de serviços pelas comunidades locais. Vantagens como esta são resultados da recepção de turistas e devem contribuir para o turismo emissivo, isto é, de turistas que saem de uma localidade para visitar uma outra.

Nesta lógica, a proposição do desenvolvimento do turismo com base local coloca em cena os sujeitos sociais emergentes e a gestão comunitária. Assim sendo, "Se os caminhos são novos, o processo decisório exige um outro norte, demanda a mobilização das lideranças locais, em todas as fases do processo, ou seja, na concepção, implantação, gestão e monitoramento dos projetos" (RODRIGUES, 1997, p.61). De certa maneira, estes caminhos apontados pela autora abrem novas possibilidades de crenças, incluindo os sujeitos locais como responsáveis pelos seus próprios projetos de desenvolvimento local. Atualmente, fala-se em agentes locais ambientais ou agentes locais de saúde, os quais recebem uma atenção maior das universidades (projetos de extensão), utilizando-se do método da pesquisa-ação e pesquisa participante, incluindo também ações das Organizações Não-Governamentais.

"No Brasil foi lançado o Programa Nacional de Educação Ambiental (1994 a 2000) versão preliminar - Documento do Ministério da Educação e do Desporto, Amazônia Legal e Ibama (Instituto Brasileiro de Meio Ambiente e dos Recursos Naturais Renováveis) [...].” (RODRIGUES, 1997, p.61). Este programa tem o propósito de garantir a formação de agentes ambientais críticos e de promover a cidadania. Eis, portanto, uma espécie de harmonia préestabelecida entre o Estado, as Organizações Não-Governamentais, as comunidades locais, a igreja, os partidos políticos e as prefeituras municipais. 
Ainda segundo a análise da autora, o que pode estar acontecendo é a formação forjada destes agentes, resultado da ação do Estado na gestão territorial local, com um discurso participativo. Há, certamente, uma probabilidade que resulta de uma superioridade de possibilidades a favor do Estado, sendo que este se coloca como o mais favorecido em todo o processo. É na construção da crença que se pode descobrir um caráter paternalista e, portanto, autoritário, isto é, o movimento para a formação de agentes ambientais tem a sua origem e é desencadeado por agentes estranhos ao grupo.

Vale, portanto, examinar a hipótese do turismo como ocupação e alternativa para os excluídos. Nesta perspectiva, parece evidente que o turismo pode ser pensado do ponto de vista da inclusão social enquanto um propósito para os excluídos, de onde deriva a influência benéfica das experiências que foram e que poderão ser obtidas com o turismo na perspectiva do desenvolvimento à escala humana. Logicamente, a proposição do "desenvolvimento à escala humana" fornece a concepção teórica e metodológica para construir reflexões sobre o turismo no território indígena Krahô.

É neste sentido que se preconiza a chamada "economia solidária" que poderá viabilizar uma segunda acumulação de capital, num outro circuito da economia, que possa reintegrar a massa de desempregados. Este ideário foi proposto por Paul Singer, durante a campanha eleitoral de Luiza Erundina à prefeitura de São Paulo, em 1996. (RODRIGUES, 1997, p.62).

Esta proposta foi analisada pela autora como uma iniciativa relevante para o setor turístico, uma vez que promove, de um lado, a economia solidária enquanto uma disponibilidade de créditos e, de outro, a possibilidade de criar empregos e qualificar a mãode-obra, constituindo, por conseguinte, as oportunidades de inserção.

No entanto, pode-se perguntar: Como o turismo se insere neste contexto? Por um lado, podem ser desenvolvidos programas de educação para o turismo nas escolas, envolvendo, assim, a comunidade e, por outro, o turismo pode ser desenvolvido no âmbito da economia informal, embora este setor receba críticas dos atores hegemônicos, inclusive obtendo um olhar carregado de preconceito. Contudo, pode-se afirmar que ações como estas constituem estratégias de sobrevivência para as classes menos favorecidas. 
No que se refere aos países periféricos em que o turismo fortalece o mercado informal, pode-se mencionar que:

O principal exemplo é o México, o primeiro país da América Latina e o oitavo do mundo, em número de turismo receptivo internacional, onde pesquisas revelam a enorme importância do mercado de trabalho, representado pelo setor informal (já que abrange mais da metade da população ativa), onde o comércio ambulante voltado para o mercado turístico é surpreendente. (RODRIGUES, 1997, p.63).

No caso específico do Brasil, a ausência de um banco de dados impossibilita fazer a mesma análise, mas há indícios de que o mercado informal também seja existente, o que permite construir uma análise do desenvolvimento em escala local.

De certa maneira, o mercado informal pode ser compreendido como uma alternativa de ocupação. A autora sugere algumas estratégias para criar oportunidades de ocupação para os excluídos que podem ser adotadas na estruturação do turismo municipal, entre elas:

1. criação de um sistema de informações para micro-investidores;

2. incentivo à formação de viveiros de micro-empresas, contando com a parceria das universidades, nos seus programas de extensão, através da pesquisa-ação;

3. apoio técnico para a abertura de microempresas e cooperativas;

4. apoio a projetos de criação de novas escolas de formação profissional, notadamente técnicas, de nível médio;

5. apoio à economia informal em parceria com a Associação Comercial e Associação de Sindicato de Economia Informal e outras entidades representativas do comércio ambulante; [...]. (RODRIGUES, 1997, p. 63).

Estas estratégias podem ser válidas para os municípios em que o turismo local constitui uma atividade econômica importante; ou seja, são propostas para a gestão local do turismo. Assim, o mercado informal tende a crescer, carecendo de uma organização em nível local. Na cidade de Itacajá - TO, por exemplo, existe o mercado informal do artesanato indígena, em que os índios Krahô vendem seus artigos para os turistas por um valor monetário abaixo do preço do mercado. Destaca-se também a existência de atravessadores, que compram por um valor e comercializam por um outro bem acima do que foi pago para os indígenas. As estratégias mencionadas pela autora podem contribuir para a organização do turismo local da cidade de Itacajá - TO e para a valorização da cultura da população indígena Krahô. 
Os turistas brasileiros e estrangeiros que chegam até a mencionada cidade têm por objetivo conhecer a população indígena Krahô. A cidade pode ser considerada um ponto de parada, de pernoite, sendo que depois o turista segue viagem até o território indígena Krahô. Uma vez colocadas em prática tais estratégias, estas podem contribuir para o fortalecimento do turismo e do mercado informal, resultando no aumento da renda para as famílias que já se encontram no setor prestando serviços diversos, tais como os encontrados em hotéis, restaurantes, padarias, supermercados, farmácias e postos de saúde, entre outros.

Portanto, a organização do turismo indígena e do turismo em territórios indígenas pode ser possível desde que se leve em conta as especificidades da localidade e do seu entorno. O território indígena pode ser considerado fronteira, uma vez que de um lado tem-se a população indígena Krahô e de outro a população não-indígena das pequenas cidades do entorno do território.

Diante do exposto, ressalta-se que a Prefeitura Municipal de Itacajá - TO carece de projetos turísticos voltados para o desenvolvimento local. Quando as atividades turísticas são organizadas para turistas estrangeiros, os índios Krahô realizam apresentações culturais, demonstrando por meio de suas manifestações uma parte da diversidade cultural brasileira. Por outro lado, torna-se possível revelar algumas atribuições das relações interculturais entre indígenas de etnias diferentes, assim como da população indígena Krahô com a população não-indígena local e de outras localidades.

Durante a realização da pesquisa de campo entre os anos de 2004, 2005 e 2006, foi possível perceber que os turistas que freqüentam a cidade de Itacajá - TO, as aldeias indígenas Krahô e a Kapey estabelecem um vínculo de amizade com os Krahô, o que contribui para fortalecer as relações de confiança entre os turistas e as comunidades indígenas.

A proposição de que há uma diferença entre os termos "turismo indígena" e "turismo em territórios indígenas" aponta a identificação de novos segmentos turísticos estruturados nas décadas de 1980, 1990 e 2000 e dos projetos que estão sendo organizados para atender às novas demandas turísticas, modo pelo qual se destaca o turismo junto às populações autóctones. Nesse sentido, um grupo de turistas pode optar por passar as férias junto às populações autóctones em diversas localidades, entre elas: Austrália, Japão, Continentes Africano e Americano. 
A demanda pelo turismo indígena e pelo turismo em seus territórios pode ser considerada crescente; por isso, faz-se necessário construir reflexões que objetivem descobrir novas concepções e técnicas de organização do turismo que correspondam às atuais tendências dos novos segmentos turísticos.

\subsubsection{Turismo indígena}

A semente do turismo indígena começa a brotar a partir da mobilidade das populações de índios para as cidades e para outros territórios indígenas. Pode-se afirmar que a população Krahô foi colocada na lógica dos aldeamentos (territórios fechados) no século XX. Buscava-se, ao mesmo tempo, praticar deslocamentos de um território indígena para outros territórios indígenas e não-indígenas (para as cidades); isto é, negava-se o projeto de aldeamentos proposto pelo Estado. Desse modo, os deslocamentos constantes podem ser entendidos como uma prática do turismo, em que o cotidiano de um lugar está articulado com o cotidiano de outros lugares.

O processo histórico de migração ao qual as populações indígenas foram submetidas reforça a hipótese de que acentuaram as relações de totalidade. Mesmo depois de fixadas em seus territórios, tais populações continuam a praticar deslocamentos para outras territorialidades com a finalidade de realizarem visitas a parentes indígenas. Por meio das visitas ocorre o fortalecimento das relações de parentesco e de amizades entre as etnias, de modo que é possível estabelecer a relação entre processo de migração, demarcação dos territórios indígenas e visitas periódicas entre as etnias como a totalidade das relações existentes, constituindo atividades turísticas sem necessariamente perpassar pelo contexto econômico.

O turismo indígena que vem sendo praticado nestes últimos séculos, no caso específico das populações indígenas do Grupo Étnico Timbira (incluindo os Krahô), teve início no final do século XVIII e início do século XIX, acentuando-se até o presente momento histórico, pois foi a partir deste recorte temporal que se iniciaram as relações interétnicas e interculturais entre os índios e entre estes e os não-índios. Os índios passaram a conviver com as cidades que foram construídas nas proximidades de seus territórios, criando, assim, as

relações de dependência. Contudo, mesmo com o surgimento das cidades, os índios preservaram a língua nativa e a tradição oral. 
Atualmente, os índios Krahô vendem artesanatos nas cidades próximas ao seu território e também nelas compram os produtos industrializados de que necessitam, como, por exemplo, roupas, aviamentos e objetos industrializados por eles utilizados na agricultura (machado, foice, enxada, entre outros). Os índios aposentados e os que estão empregados na educação e na saúde são praticamente os únicos que possuem renda mensal. Em geral, são estes que compram os produtos vendidos nas cidades próximas às aldeias.

Estes índios, freqüentemente, necessitam da assistência médica oferecida nas cidades. Nesse sentido, vale ressaltar que a saúde das populações indígenas está sob a responsabilidade da Funasa, que mantém seus pólos-base nas pequenas cidades, entre as quais Itacajá - TO e Goiatins - TO. Os índios que necessitam de um tratamento de saúde mais complexo, entretanto, seguem para Araguaína, cidade que polariza as regiões do Norte do estado do Tocantins e do Sul dos estados do Maranhão e do Pará.

A mobilidade tornou-se uma regra para os Krahô em função sobretudo do comércio e dos serviços de saúde e bancários que são oferecidos nas cidades próximas ao seu território. A sede da Funai - Administração Regional de Araguaína -, que pode ser definida como o lugar onde os índios registram as suas reivindicações e estabelecem negociações de interesse de suas comunidades, também justifica tal mobilidade. ${ }^{32}$

Para legitimar a existência do turismo indígena no estado do Tocantins faz-se necessária uma análise precedente de observação, por meio da qual pode-se verificar que os índios possuem tanta liberdade de mobilidade quanto os não-índios. Ou seja, os indígenas não têm proibição para realizar as suas viagens, desde que tenham os recursos financeiros suficientes para o intercâmbio. Pode-se dizer, ainda, que quando o índio viaja de sua aldeia para a cidade de Araguaína para se submeter a cuidados médicos, tratar de problemas

\footnotetext{
${ }^{32}$ Segundo o participante Getúlio Krahô, a Funai, Administração Regional de Araguaína - TO, pode ser transferida para a Cidade de Palmas - TO, ficando mais distante dos índios do norte do estado do Tocantins (Apinayè/Tocantinópolis, Karajá/Santa Fé do Araguaia, Krahô/Itacajá e Goiatins), do sul do Maranhão (Canela/Ramkokamekrá, Canela/Apãnikrá, Gavião/Pïkobyê e Krikati) e do sul do Pará (Guarani e Kaiapó). Atualmente, os índios viajam com mais freqüência para a cidade de Araguaina do que para a Capital do estado do Tocantins. A Funai/Administração Regional de Goiânia foi responsável pela assistência aos índios do norte do estado de Goiás até o ano de 1987, ano em que foi criada a Administração Regional de Araguaína. Agora, em 2006, cogita-se a mudança para a Capital do Estado. De acordo com o pensamento de Getúlio Krahô, pode ser importante manter a Funai/Regional de Araguaína e abrir outra regional em Palmas, sendo que esta última atenderia aos Xerente (Gurupi e Palmas) e aos Karajá, Javaé e Xerente (Ilha do Bananal). Nesta lógica, os índios Krahô, os Apinayè e os Karajá (Santa Fé do Araguaia - TO) discordam da proposta de mudança da Funai, Regional de Araguaína, para a cidade de Palmas - TO.
} 
bancários, fazer compras ou reivindicar o apoio da Funai e da Funasa está, de certa maneira, praticando o turismo. Tais atividades, portanto, influenciam a prática do turismo indígena e fortalecem os princípios da liberdade e da mobilidade dos índios.

Estando nas cidades, os índios podem se interessar também por outras atividades, como caminhar pelas ruas e visitar amigos (relações de amizades). A ilimitada liberdade do homem contribui para que numa situação de mobilidade e de sociabilidade este faça atividades além daquelas anteriormente programadas.

Os Krahô, na tentativa de obterem a aprovação dos seus projetos junto aos órgãos de pesquisa e de financiamento, deslocam-se para localidades dentro do próprio estado do Tocantins - como Araguaína, Colinas e Palmas - ou fora deste, como São Paulo ${ }^{33}$, Rio de Janeiro e Brasília. Alguns índios Krahô já viajaram, inclusive, para cidades européias, como Paris (França), Roma, Nápoles e Milão (Itália). Getúlio Krahô, por exemplo, Coordenador Geral da Kapey-União das Aldeias Krahô de 1993 (ano de fundação da associação) até o início de 2004, realizou, durante este período, diversas viagens pelo Brasil e pelo exterior.

Segundo Getúlio Krahô, foi a partir dos anos 1990 que os índios Krahô começaram a viajar para outros países do continente americano e para a Europa. Entre os anos de 1995 e 1996, um índio da aldeia Galheiros viajou para a Venezuela, para Cuba e para o México com os indigenistas do Centro de Trabalhador Indigenista (C.T.I). Em 2003, Getúlio Krahô, por sua vez, viajou para Paris (França), Roma, Milão e Nápoles (Itália) para participar de um evento internacional com o projeto "Recuperação da Agricultura Tradicional Indígena e de seus Valores Culturais", que contou com a participação de aproximadamente oitenta (80) etnias de vários países. Neste evento, realizado em Nápolis (Itália) e promovido pela

\footnotetext{
${ }^{33}$ De acordo com o depoimento do participante Getúlio Krahô, no ano de 1998 os Krahô receberam o primeiro prêmio no Brasil, concedido pela Fundação Getúlio Vargas (SP), pela reintrodução de sementes nativas - "Experiência premiada em 1998" no valor de dez mil reais (R\$10.000,00). Com o dinheiro deste prêmio comprou-se uma casa para sediar o escritório da Kapey, na cidade de Itacajá. Este escritório está funcionando, servindo também para alojamento dos índios que estão cursando o Ensino Médio na referida cidade. Este prêmio reforçou a identidade étnica dos Krahô, assim como as "iniciativas para a promoção dos direitos das comunidades indígenas" brasileiras. Por intermédio da Kapey, isto é, dos trabalhos que vêm sendo desenvolvidos desde a data de sua fundação (1993), estão sendo proporcionadas oportunidades de inclusão social dos Krahô. Por meio das ações da Kapey no desenvolvimento dos projetos, de certa maneira, os Krahô ficaram conhecidos pelas iniciativas que tiveram no apontamento de soluções para a crise econômica e social enfrentada desde as décadas de 1960, 1970, 1980 e 1990. Na última década do século XX e nos primeiros cinco anos do século XXI, muitos projetos foram desenvolvidos com o apoio de órgãos governamentais, não-governamentais $\mathrm{e}$ universidades.
} 
Organização Não-Governamental Slow Food, os Krahô receberam o prêmio Slow Food de defesa da Biodiversidade e foram premiados com treze (13) mil euros.

Nesta primeira viagem, o então Coordenador Geral da Kapey-União das Aldeias Krahô contou com a companhia do Gestor dos Projetos Krahô e indigenista da Funai Fernando Schiavini. Na ocasião, foi a Roma (Itália) encontrar um amigo italiano que já havia visitado os Krahô no Brasil. Permaneceu viajando por um período de dezoito (18) dias, durante o qual visitou Paris (França), Nápolis e Roma (Itália). Em 2004, Getúlio Krahô foi, ainda, a Milão (Itália) para um novo evento promovido pelo Instituto Slow Food, no qual recebeu o prêmio do ano de 2003 e foi convidado a participar como jurado do evento do ano de 2004, tendo as despesas de viagem pagas pelo referido Instituto.

Getúlio Krahô, durante o período em que esteve na Coordenação da Kapey, realizou, portanto, duas (02) viagens para a Europa. Nesta ocasião, aproveitou para divulgar o artesanato Krahô, levando algumas peças para vender durante a viagem, sendo que todas foram comercializadas na cidade de Roma (Itália), o que motivou a criação do projeto "Resgate do Artesanato Krahô", que possibilitou a construção da Casa do Artesanato Krahô, na sede da Kapey. Depois que Getúlio retornou para o território indígena Krahô, foram organizadas reuniões na Kapey e nas comunidades indígenas das dezoito (18) aldeias para informar a premiação recebida, assim como a vivência nos países visitados. A obtenção deste prêmio contribuiu para reforçar a identidade étnica Krahô, a auto-estima desta população, bem como a sua visibilidade diante das demais etnias brasileiras e estrangeiras. Dessa maneira, os Krahô conseguiram se inserir nos cenários brasileiro e mundial.

Desse modo, as condições para terem os "fixos" provocam os fluxos, isto é, os deslocamentos para outras territorialidades. Nesta lógica,

A tendência a uma interdependência maior é acompanhada de maior diversificação e expansão dos objetos técnicos no espaço. Ao mesmo tempo em que as atividades capitalistas vão aumentando a sua presença no território, o oposto se dá com os espaços indiferenciados. (SANTOS, 1997, p.80).

A evolução dos sistemas de engenharia tende a tornar-se mais complexa, tendo um conjunto de técnicas cada vez mais estranhas para as comunidades que as utilizam. As mudanças dos objetos técnicos instalam novos "fixos", "Passamos também de fluxos que são 
curtos no espaço e que se exercem em áreas limitadas a fluxos que abrangem frações territoriais cada vez maiores" (SANTOS, 1997, p.81).

O caso específico dos Krahô, no Estado do Tocantins (Amazônia Brasileira), ilustra a constante mobilidade para os territórios de outras etnias, como por exemplo: Território Indígena Apinayè (Tocantins), Canela/Ramkokamekrá, Canela/Apanikra, Gaviões, Krikati/Pïkobyê (Maranhão), Xerente (Tocantins), Xavante (Mato Grosso), Terena (Mato Grosso), Apurinã e Kaxinawá (Acre), Guarani (Pará), Kaiapó (sul do estado do Pará), entre outras. No entanto, a mobilidade das populações indígenas poderia ocorrer com ainda mais intensidade se a falta de recursos financeiros não a limitasse, valendo ressaltar, nesse sentido, que nem sempre os índios têm o apoio financeiro da Funai para realizar as suas viagens. $\mathrm{Na}$ maioria das vezes, as viagens são realizadas a convite da Funai, da Funasa, das Universidades e das Organizações Não-Governamentais. Portanto, o turismo indígena está relacionado à questão do turismo, isto é, a mobilidade dos índios pode ser vista como uma prática do turismo.

Há inúmeros exemplos que podem ser usados para fundamentar tais argumentos, entre os quais: Feira Krahô de Sementes Tradicionais ${ }^{34}$, I Encontro de Cantadores Timbira ${ }^{35}$, Fórum Cultural Mundial ${ }^{36}$, I Festival de Música Apinayè, I Fórum Social Indígena do Tocantins ${ }^{37}$, Jogos das Populações Indígenas, entre outros.

\footnotetext{
${ }^{34}$ Realizada no Território Indígena Krahô desde o ano de 1997, ano em que foi organizada a primeira. Em 2004, aconteceu a VI Feira, que contou com a participação dos índios de várias etnias e de nãoíndios brasileiros e estrangeiros.

35 Realizado pela Associação Wyty-Cati, sede da Escola Timbira, localizada na área rural do município de Carolina-MA, realizado entre os dias 02 a 06 de fevereiro de 2004. Estiveram presentes as etnias do Grupo Étnico Timbira. Este evento foi organizado pelas Associações Indígenas e pelo Centro de Trabalhador Indigenista (C.T.I); estavam presentes aproximadamente duzentos índios, além dos não-índios.

36 "Realizado entre os dias 26 de junho e 04 de julho de 2004. Contou com a participação dos representantes das etnias Krenak, Kaiabi, Kayapó, Kechua, Baniwa, Yamanawá, Xavante, Guarani, Bakairi, Ikepeng, Ticuna, Karajá, Tucano, Yanomani, Yawalapiti, Kaiowá, Nambikawara, Yudja, apresentaram várias formas de arte que compõem o universo indígena, com instalações por meio das quais o público presencia o trabalho de criação in loco. Aconteceram apresentações de rituais das etnias Guarani e Kayapó. Entre os artesanatos que foram expostos durante o evento, no Sesc/Belenzinho, cestaria de buriti (Xavante), Cestaria de fibra e animais em madeira (Guarani, São Paulo), colar de tucum (Nambikawara, Mato Grosso), cerâmica e beiju (Wauja, Mato Grosso), tecelagem (Yudja, Mato Grosso), pintura corporal (Kayapó, Pará).” (FÓRUM CULTURAL MUNDIAL/PROGRAMAÇÃO SESC-BELENZINHO, 26 de junho a 04 de julho de 2004).

${ }^{37}$ Realizado na cidade de Palmas - TO, entre os dias 05 e 07 de abril de 2005, organizado pela Secretaria da Cidadania e Justiça, Estado do Tocantins. Todos os representantes das etnias do
} 
O Projeto Escola Catxêkwy - Vivência Agroambiental - foi desenvolvido com recursos do PDPI - Projetos Demonstrativos dos Povos Indígenas, aprovado no ano de 2000. Tais recursos foram liberados em 2003, o que permitiu a realização das viagens dos quarenta (40) alunos da Escola Catxekwy, que visitaram as aldeias das Etnias do Grupo Étnico Timbira, em 2005, com o objetivo de conhecerem a agricultura tradicional das populações indígenas Apinayè (Tocantins), Krikati e Canela (Maranhão). As relações interétnicas e interculturais entre as populações indígenas do Grupo Étnico Timbira contribuem para a valorização cultural, para o desenvolvimento de atividades econômicas sustentáveis e para a proteção do território.

A troca de experiência entre as populações indígenas pode ser considerada como um intercâmbio que ocorre nos sentidos econômico, político, cultural e ambiental. As políticas públicas setoriais para as populações indígenas são semelhantes; por isso pode-se encontrar associações indígenas com projetos parecidos aos dos Krahô. Do ponto de vista da experiência integrada, do espaço e do sentido relacional de território, quando as experiências são vivenciadas e discutidas podem resultar num retorno para as populações indígenas.

De certa maneira, os povos indígenas possuem um valioso patrimônio, que se manifesta na realização dos rituais dentro de um calendário anual. Os fluxos turísticos das populações indígenas são construídos pela valiosa atenção e importância que uma etnia atribui aos rituais de outras etnias. Por exemplo, os povos indígenas Krahô participam dos rituais das etnias Apinayé (estado do Tocantins), Canela/Ramkokamekrá, Canela/Apãnikrá, Gavião/ Pïkopjê e Krĩkati (Maranhão), pois pertencem ao mesmo Grupo Étnico Timbira. À medida que são constituídas as relações de parentesco de uma etnia com outras etnias aumenta a mobilidade entre as populações indígenas.

Nessa perspectiva, pode ser possível defender a proposição de que a inclusão social das populações indígenas contribui para o aumento dos fluxos turísticos, isto é, da prática do turismo indígena, situação que pode diminuir a reclusão em seus territórios, uma vez que a falta de uma renda familiar dificulta a realização das viagens, mantendo pouco ou nenhum contato interétnico e intercultural com os parentes e com a população não-indígena.

Tocantins marcaram presença, além dos representantes das etnias Terena (Mato Grosso do Sul), Guarani (Pará), Ashaninka (Acre) e Krikati (Maranhão). 
Durante suas viagens para outros territórios indígenas e para as cidades, os índios mantêm contatos culturais, trocam, ensinam e aprendem experiências novas. Ao retornarem para as suas comunidades têm novos assuntos para serem discutidos, o que não seria possível sem o acontecimento da viagem. Certamente, a mobilidade dos índios está relacionada ao direito de ir e vir, uma vez que estes podem fazer o uso legítimo desse direito tanto para vivenciarem o cotidiano dos índios de outras etnias ${ }^{38}$, quanto para conhecerem a agitação das pequenas, médias e grandes cidades.

A análise do que está acontecendo permite propor uma explicação que seja compatível com a realidade dos Krahô. Outros eventos que acontecem nos territórios indígenas ou fora destes poderiam ser mencionados, mas não é o caso de se empilhar um número considerável de eventos para justificar a existência do turismo indígena. No entanto, deve-se ressaltar que, de um lado, os eventos realizados no interior dos territórios indígenas podem ser considerados atrativos para as comunidades indígenas e não-indígenas e, de outro, os eventos externos aos territórios indígenas que envolvem os índios em suas representações culturais expressam atrativos turísticos para os povos não-indígenas, fortalecendo a participação de ambos na prática do turismo indígena.

${ }^{38}$ Relato da viagem do participante Getúlio Krahô para os Canela/Apãnikrá, Aldeia Porquinho, que fica a setenta (70) kilômetros da cidade de Grajaú, no estado do Maranhão. Saiu da Aldeia Manoel Alves com a família (esposa, filhos, sobrinhos e genros) totalizando um número de nove (09) índios no caminhão da Funai no dia 07 de julho de 2005, chegou em Araguaína no mesmo dia, apenas no dia 14 de julho de 2005 seguiu de viagem no caminhão da Funai para a Aldeia Porquinho/Canela, chegando no mesmo dia, após dez (10) horas de viagem. Permaneceu com a família nesta Aldeia até o dia primeiro (01) de setembro de 2005. Encontrou os Krahô da aldeia Nova num intercâmbio com os Canela/Apãnikrá, aproveitou para fazer o acompanhamento que teve o intuito de demarcar o território indígena desta etnia (em processo de demarcação pelo governo federal). Os índios Krahô da Aldeia Nova passaram sete (07) dias, em seguida, retornaram para o Território Indígena Krahô. Depois, Getúlio Krahô acompanhou a organização das atividades culturais da comunidade indígena da aldeia Porquinho, por exemplo, marcação dos rituais, obteve informações sobre os trabalhos das associações indígenas e dos projetos que foram aprovados pelo Projeto Demonstrativo dos Povos indígenas/PDPI (Apicultura e Criação de Emas). Getúlio Krahô comenta que foi organizado um ritual com representação da cultura indígena para a recepção da sua chegada com a família. Senhor Getúlio tem quatro (04) primos e uma (01) prima nos Canela/Apãnikrá, a viagem teve um caráter de visita familiar e de consulta ao pajé para cuidar da saúde do genro, mas ao mesmo tempo aconteceram outras atividades que a priori não haviam sido programadas. Realizou-se um ritual de iniciação dos jovens Canela/Apãnikrá (situação em que ocorre a prisão em casa com a família), os quais permaneceram quatro (04) meses em reclusão, onde oitenta e quatro (84) jovens com idades entre dezessete (17) e dezoito (18) anos, depois da permanência em suas casas, com as famílias houve a terminação do ritual de iniciação. Segundo as informações de Getúlio havia um Suíço, fazendo o registro do término do ritual e, que durante a realização do ritual foram cantadas cantigas dos índios Canela/Apãnikrá. Este ritual antigamente era realizado nos Krahô, de modo que gostou muito de fazer a viagem, de participar e de obter informações dos projetos que estão sendo desenvolvidos pelas associações indígenas. 
Entre os eventos que merecem uma análise minuciosa destacam-se os jogos indígenas, que se tornaram verdadeiras atrações turísticas. Na realização destes jogos, os índios são considerados os principais atrativos para os índios e para os não-índios, o que reforça os diversos contatos culturais.

\subsubsection{Jogos das Populações Indígenas}

A organização dos Jogos das Populações Indígenas pode ser considerada uma iniciativa positiva por parte dos seus idealizadores, pois contribui para a elevação da autoestima e a interação sócio-cultural de várias etnias brasileiras e estrangeiras. Cada etnia possui habilidades em esportes específicos, o que exige treinamentos e preparos para a participação neste evento.

Os Jogos Indígenas tomaram dimensões nacional e internacional a partir da organização da sua primeira versão, realizada na cidade de Goiânia, em 1996. Já em 2004 aconteceu a sétima edição deste evento, realizada na cidade de Porto Seguro, que contou com um número expressivo de populações indígenas e não-indígenas (brasileiras e estrangeiras), promovendo, novamente, os contatos culturais entre diferentes populações.

De acordo com Carlos Terena, a idéia da criação dos jogos indígenas surgiu em 1978, mas o projeto não contou com apoio imediato. A Funai, a Funasa e o Ministério da Educação e do Desporto nunca mobilizaram esforços para facilitar a sua organização. Somente em 1996, com o apoio de Edson Arantes do Nascimento, o famoso Pelé, então Ministro dos Esportes, foi possível realizar o primeiro evento ${ }^{39}$ e, por conseguinte, acentuar as relações entre as diferentes culturas. Dessa maneira, as populações indígenas puderam reafirmar as suas singularidades num contexto único e complexo. ${ }^{40}$

O artigo de Azevedo (2005, p.01-13) intitulado "Jogos dos povos indígenas: apropriação de ritos, tradições e manifestações culturais pelo turismo" contribui para reforçar a proposição de que o turismo indígena está se configurando cada vez mais como um novo segmento turístico nacional e internacional. Sobre os jogos indígenas, esta autora afirma:

${ }^{39}$ Notas de um depoimento do informante Carlos Terena, considerado o idealizador dos Jogos Indígenas no Brasil. (FÓRUM SOCIAL DOS POVOS INDÍGENAS DO TOCANTINS, 06/04/2005).

40 “....] Os jogos indígenas foram organizados com o apoio do Ministério Extraordinário dos Esportes, executado pelo Instituto Nacional do Desporto, com o apoio do Comitê Inter-tribal e da Fundação Nacional do Índio.” (AZEVEDO, 2005, p.02). 
O financiamento aos jogos indígenas advém de duas fontes: sua maior parte, $70 \%$ provém do governo federal, via Ministério dos Esportes; $30 \%$ são de responsabilidade do governo estadual do município escolhido para realizar o evento. Sobre os objetivos dos jogos, conforme seu coordenador cultural, o indígena Carlos Terena, os mesmos visavam o conhecimento entre as diversas etnias, entretanto, a cada edição coisas diferentes aconteceram. (AZEVEDO, 2005, p.02).

A autora argumenta também que os jogos indígenas podem ser considerados relevantes para o autoconhecimento, para o partilhar das tradições com outras etnias e para a promoção da auto-estima dos povos indígenas. Por isso, as dimensões cultural e étnica estão sendo configuradas para o turismo indígena e sendo divulgadas a partir do marketing de visibilidade nacional e internacional.

A seguir, pode-se observar o ano e o local em que cada edição dos Jogos das Populações Indígenas foi realizada.

Tabela 01 - Jogos das Populações Indígenas

\begin{tabular}{|l|c|l|}
\hline \multicolumn{1}{|c|}{ Jogos das Populações Indígenas } & Ano de Realização & \multicolumn{1}{c|}{ Localidade } \\
\hline I Jogos das Populações Indígenas & 1996 & Goiânia - GO \\
\hline II Jogos das Populações Indígenas & 1999 & Guairá - PR \\
\hline III Jogos das Populações Indígenas & 2000 & Marabá - PA \\
\hline IV Jogos das Populações Indígenas & 2001 & Campo Grande - MS \\
\hline V Jogos das Populações Indígenas & 2002 & Marapanin - PA \\
\hline VI Jogos das Populações Indígenas & 2003 & Palmas - TO \\
\hline VII Jogos das Populações Indígenas & 2004 & Porto Seguro - BA \\
\hline
\end{tabular}

Fonte: www.funai.gov.br/indios/jogos.htm.

O I Jogos das Populações Indígenas, conforme observado anteriormente, foi realizado na cidade de Goiânia, em 1996. De acordo com Carlos Terena, esta primeira edição do evento foi o início de uma experiência que, mais tarde, seria aprimorada. A canoagem, por exemplo, modalidade que fez parte das competições, contou com alguns problemas, já que nem todas as canoas fabricadas pelos próprios índios estavam dentro dos padrões da prova, o que causou confusão durante o evento. A população indígena Erikbatsa foi considerada a que produziu as melhores canoas; foram as suas almadias as indicadas para o uso nas competições 
seguintes. Assim, os Erikbatsa ficaram conhecidos como canoeiros, tendo uma grande agilidade em sua utilização.

Além da canoagem, estavam entre as modalidades do I Jogos das Populações Indígenas: futebol de campo, natação, arco e flecha, arremesso de lança, demonstrações de luta e corrida de tora. As etnias que estiveram presentes no evento foram: Bakairi - Mato Grosso; Bororo - Mato Grosso; Fulniô - Pernambuco; Gavião - Rondônia; Guarani - São Paulo e Mato Grosso do Sul; Kadiwéu - Mato Grosso do Sul; Kaigang - São Paulo, Santa Catarina e Rio Grande do Sul; Kamayurá - Mato Grosso; Xingu - Mato Grosso; Karajá Tocantins; Kaixá - Mato Grosso do Sul; Krahô - Tocantins; Krikati - Maranhão; Saterê-Maués - Amazônia; Ofaié - Mato Grosso do Sul; Paresi - Mato Grosso; Terena - Mato Grosso; Tukano - Amazônia; Xucuru - Alagoas; Kariri - Alagoas; Yawalapiti - Mato Grosso; Kuikuro - Mato Grosso; Wuará - Mato Grosso; Xavante - Mato Grosso; Kalapalo - Mato Grosso; Trumai - Mato Grosso; Mehinaku - Mato Grosso; Kaiapó - Pará; Javaé - Tocantins; e Kanela Maranhão. ${ }^{41}$

O II Jogos das Populações Indígenas aconteceu na cidade de Guairá, no Paraná, em 1999. As competições de canoagem ocorreram no Centro Náutico Marinas e no rio Paraguai, com quatro (04) baterias de provas. Esta edição do evento contou com a participação de 500 índios de várias etnias, as quais conviveram durante sete (07) dias nos alojamentos para os competidores. Estavam entre as principais modalidades de esportes o atletismo e o arco e flecha. A população indígena Paresi participou da prova de Xikunahity, uma espécie de futebol praticado com a cabeça, e de Tihimoré, modalidade esportiva semelhante ao boliche e praticada pelas mulheres. Nas provas de canoagem, natação e corrida de tora, as etnias participantes foram: Guarani - São Paulo; Potiguara - Paraíba; Pankararu - Pernambuco; Maxacali - Minas Gerais; Krenak - Minas Gerais; Paresi - Mato Grosso; Umutina - Mato Grosso; Kaigang - Santa Catarina; Kaiowá - Mato Grosso do Sul; Kadiwéu - Mato Grosso do Sul; Bakairi - Mato Grosso; Boror - Mato Grosso; Erikbaktsa - Mato Grosso; Kanela Maranhão; Matis - Amazônia; Krahô - Tocantins; Kayapó - Pará; Xavante - Mato Grosso; Waurá - Mato Grosso; e Terena - Mato Grosso do Sul. ${ }^{42}$

O III Jogos das Populações Indígenas, por sua vez, ocorreu no município de Marabá, no Pará, em 2000. As modalidades de esportes mais disputadas foram o cabo-de-guerra, a

${ }^{41}$ Fonte: www.funai.gov.br/indios/jogos/1o_jogos/1_jogos.htm. Consultado em 07/10/2005.

${ }^{42}$ Fonte: www.funai.gov.br/indios/jogos/2o_jogos/2_jogos.htm. Consultado em 07/10/2005. 
corrida de tora, a canoagem, o futebol e o arco e flecha. A arena turística foi construída na Praia do Tucunaré, às margens do rio Tocantins. Novecentos (900) índios de várias etnias participaram das competições. De acordo com Carlos Terena (2000):

Uma aldeia olímpica e uma arena com capacidade para dez (10) mil pessoas foram montadas com o apoio do Ministério dos Esportes e Turismo, do Instituto Nacional de Desenvolvimento do Esporte - IDESP, do governo do estado do Pará, da Secretaria Executiva de Esporte e Lazer, da Prefeitura da cidade de Marabá, da Funai e do Comitê Intertribal. Com o objetivo de promover a integração esportiva e cultural, os organizadores e os índios fizeram da cidade de Marabá uma grande "aldeia".

As etnias que participaram desta edição do evento foram: Bororo - Mato Grosso; Bakairi - Mato Grosso; Xavante - Mato Grosso; Xickin - Mato Grosso; Arara - Pará; Mundukuru - Pará; Krahô - Tocantins; Tembé - Pará; Suruí - Pará; Kaapor - Pará; Parakanã Pará; Matis - Amazônia; Kaiowá - Mato Grosso do Sul; Guarani - São Paulo; Mbyá - Pará; Kaigang - Paraná; Pataxó - Bahia; Karajá - Tocantins; Asurini - Pará; Gavião - Rondônia; Parkatejê - Pará; Terena - Mato Grosso do Sul; Kanela - Maranhão; Wai Wai - Pará; Yawalapiti - Mato Grosso; Kuikuru - Mato Grosso; Kamayurá - Mato Grosso; Kalapalo Mato Grosso; Waurá - Mato Grosso; Mehinaku - Mato Grosso; Erikbatsa - Mato Grosso; Jawaé - Tocantins; Suyá - Mato Grosso; Arawete - Pará; Assurini - Pará; e Kayapó - Pará. ${ }^{43}$

O IV Jogos das Populações Indígenas foi realizado em 2001, na cidade de Campo Grande, no Mato Grosso do Sul, mais especificamente no Parque das Nações Unidas, onde foram instaladas quinze (15) ocas. Aproximadamente oitocentos e cinqüenta (850) índios de várias etnias marcaram presença na quarta $\left(4^{\mathrm{a}}\right)$ edição deste evento. Entre as suas modalidades de esportes destacavam-se: natação, canoagem, arco e flecha, corrida de tora, zarabatana e lutas tradicionais. ${ }^{44}$

Já o V Jogos das Populações Indígenas foi realizado na cidade de Marapanim, no estado do Pará, em 2002. As competições individuais do evento foram: arco e flecha, arremesso de lança, natação, natação com travessia de rio, atletismo e corrida de fundo. Entre as competições coletivas estavam o cabo de guerra, a canoagem, a corrida de tora, o futebol masculino e feminino, o katukaywa (futebol de joelho, esporte típico das populações indígenas Xinguano), o Tihimore (arremesso de bola de marmelo, praticado pelas mulheres

\footnotetext{
${ }^{43}$ Fonte: www.funai.gov.br/indios/jogos/3o_jogos/3_jogos.htm. Consultado em 07/10/2005.

${ }^{44}$ Fonte: www.2.uol.com.br/campogrande/temmais/jogosindigenas. Consultado em 13/10/2005.
} 
Paresi) e o Akô (corrida de varinha), entre outras. De acordo com as informações do Ministério do Planejamento:

Os jogos de 2002, que são uma realização do Ministério do Esporte e Turismo, devem ganhar destaque espontâneo da mídia internacional, a exemplo, de anos anteriores - já são inúmeros os pedidos de credenciamento para a festa brasileira considerada uma das mais tradicionais da América e a expectativa é de que os "Cara de Onça", os "Gavião Parakateyè", o Povo Xavante ou o "Povo Krahô" novamente tenham espaço nas páginas das principais revistas européias. ${ }^{45}$

O VI Jogos das Populações Indígenas, por sua vez, ocorreu na Praia da Graciosa, em Palmas, no estado do Tocantins, em 2003. Esta edição foi patrocinada pelo Ministério dos Esportes e organizada pela Secretaria de Esporte do Tocantins, que contou com o apoio da Prefeitura Municipal de Palmas e da Fundação Nacional do Índio. Para a realização deste evento, que contou com a participação de mil e duzentos (1.200) atletas indígenas, foi necessária a construção de uma "arena turística" na Praia da Graciosa. Teve destaque também a participação dos não-índios como espectadores, os quais prestigiaram as diversas modalidades de jogos, as representações culturais (danças indígenas) e a venda de artesanatos durante o evento. Principalmente os paulistas aproveitaram para adquirir os artigos produzidos pelos índios, no intuito de revendê-los no mercado da cidade de São Paulo.

Além de trinta (30) ocas para abrigar as etnias indígenas, o governo está finalizando esta tarde (31 de outubro de 2003) a cobertura em palha de construções para exposição e venda do artesanato, mostra de vídeo e palestras, atendimento médico da Funasa, refeitório e administração. A venda do artesanato, um dos pontos altos do evento, já está sendo improvisada pelos Karajá, de Tocantins, Matis, Enawenê-Nawê, Tembé, Taipirapé e Pataxó. Eles expuseram sua arte plumária, cocares, colares, brincos e outros artesanatos na entrada das ocas. ${ }^{46}$

As etnias que participaram desta edição do evento foram: Wai Wai; Tapirapé; Bakairi; Awa-Guajá; Ka’por; Karajá; Bororo; Enawenê-Nawê; Tembé; Yawalapiti; Kanela; Kaiwá; Rikbatsa; Apinayè; Suruí; Paresi; Nambikwara; Xavante; Xicrim; Terena; Matis;

45 Fonte: www.planejamento.gov.br/planejamento_investimento/conteúdo/notícias. Consultado em 13/10/2005.

${ }^{46}$ Fonte: www.funai.gov.br/ultimas notícias/2 semestre 2003. Consultado em 07/10/2005. 
Pataxó; Cinta Larga; Krahô; Guarani; Javaé; Xerente; Gavião; Aikewara; Waiãpi; Karipuna; Kalinã; e Waiãpi - Guiana Francesa. ${ }^{47}$

Apenas na sexta edição dos Jogos das Populações Indígenas a Fundação Nacional de Saúde (Funasa) firmou convênio com a Secretaria Estadual de Saúde (Tocantins) e com a Secretaria Municipal de Saúde para atender os atletas durante os jogos. Foi, então, construída uma oca, onde os índios recebiam orientações básicas, como quanto à proibição da venda e do consumo de bebidas alcoólicas, à prevenção de doenças sexualmente transmissíveis e ao perigo do tabagismo (já que este prejudica o desempenho nas atividades desportivas). Sobre a atuação da Funasa, vale ressaltar:

A Funasa tem desenvolvido importantes ações nas áreas de saúde e saneamento, como a realização de cursos de formação de Agentes Indígenas de Saúde (AIS) e Agentes Indígenas de Saneamento (AISAN) para atuarem diretamente nas aldeias de suas respectivas etnias. (FUNAI, 2005, p.01-02).

Ainda no que se refere à Funasa, esta promovia nas aldeias orientações sobre o fornecimento de água, a higiene pessoal, o tratamento e a destinação de esgotos e sobre o recolhimento e o tratamento de resíduos sólidos.

A corrida de tora constitui uma das modalidades esportivas tradicionais praticadas pelos Krahô e Xerente, do Tocantins; pelos Xavante, do Mato Grosso; pelos Kanela, do Maranhão; e pelos Gavião e Kyikatêjê, do Pará, que participaram da sexta edição dos Jogos Indígenas. Esta modalidade de esporte indígena, segundo Carlos Terena, é a que faz a platéia não-indígena vibrar nas arquibancadas. Os jogos de futebol masculino aconteceram entre as seguintes etnias: Pataxó x Yawalapiti (Xiguano); Suruí x Xerente; Wai Wai x Javaé; Xilkrin x Tembé; Kaapor x Guiana Francesa; Apinayè x Xavante; Bororo x Gavião; Guarani x Terena; Kanela x Karajá; e Nambikwara x Kaiapó. As partidas de futebol masculino foram realizadas no Estádio Nilton Santos, em Palmas.

O futebol feminino contou com a participação das seguintes etnias: Kayapó, Bakairi, Krahô, Bororo, Kyikatêjê, Pataxó, Kaiwá, Rukbasta, Karajá, Tapirapé, Aikewara e Paresi. Tais etnias demonstraram agilidade nas partidas de futebol e contaram com o apoio de torcedores/as indígenas e não-indígenas, o que demonstra a integração cultural promovida no evento. As partidas de futebol feminino ocorreram na Associação Atlética do Banco do Brasil.

\footnotetext{
${ }^{47}$ Fonte: www.funai.gov.br/ultimas/noticias/2_semestre_2003. Consultado em 07/10/2005.
} 
Na competição de arco e flecha, dois competidores representavam cada etnia durante os jogos. Esta modalidade de esporte pode ser considerada comum para a maioria das etnias brasileiras. A competição de lança, por sua vez, envolveu as seguintes etnias: Xikrin - Pará; Aikewara - Pará; Javaé - Tocantins; Matis - Amazônia; Guarani - São Paulo; Nambikuara Mato Grosso; Yawalapiti - Mato Grosso; Karipuna - Amapá; Bakairi - Mato Grosso; Enawenê-Nawê - Mato Grosso; Cinta Larga - Rondônia; Apinayè - Tocantins; Kaiapó - Pará; Kanela - Maranhão; e Pataxó - Bahia.

A representação cultural (danças) dos Gavião e dos Kyikatêjê, do Pará; dos Guarani e dos Kaiwá, do Mato Grosso do Sul; dos Matis, da Amazônia; e dos Nambikwara, do Mato Grosso, alegravam os parentes indígenas das demais etnias participantes e também os nãoíndios.

Por último, o VII Jogos das Populações Indígenas foi realizado em Porto Seguro, estado da Bahia, no ano de 2004. Para esta edição, foi montada uma arena na Reserva da Jaqueira, território da população indígena Pataxó. A competição entre as etnias teve como referência dezesseis (16) modalidades esportivas, entre as quais: arco e flecha, canoagem, arremesso de lança, cabo de força, corrida de tora, lutas corporais (zarabtana, xikunahity, tihimore, katulaya, akô e jãmpati), futebol de campo, atletismo, natação e corrida de fundo. As etnias participantes foram: Aikewara, Assurini, Awá, Guajá, Aweti, Bakairi, Bororo, Enawenê-Nawê, Etnias Australianas, Etnias Canadenses, Gavião do Pará, Guajajara, Guarani, Ikpeng, Irantxe, Javaé, Kaapor, Kadiwéu, Kaigang, Kaiwá, Kalapalo, Kamayurá, Kanela, Kantaruré, Karajá, Kayabi, Kayapó, Kiriri, Krahô, Krenak, Kuikuro, Matis, Maxacali, Nambikwara, Pankararu, Paresi, Pataxó, Rikbatsa, Suruí, Tapirapé, Terena, Tuxá, Wai Wai, Waiãpi, Wairiri, Atroari, Waurá, Wayapi - da Guiana Francesa, Xakriabá, Xavante, Xerente, Xikrin, Xucuru, Kariri, Yanomani e Yawalapiti. ${ }^{48}$

Portanto, com a realização dos jogos indígenas, diversas atividades culturais acontecem nas arenas dos esportes tradicionais, incluindo as representações culturais de cada população, as mostras de artesanato e a sua comercialização. De um modo geral, os jogos indígenas tradicionais contribuem para fortalecer a identidade étnica das populações indígenas brasileiras e estrangeiras. Podem ser considerados como um evento turístico voltado tanto para as populações indígenas quanto para os não-índios.

${ }^{48}$ Fonte: www.atlanticanews.com.br/notícias/jogos_indios_ps.htm. Consultado em 13/10/2005. 
As edições dos Jogos das Populações Indígenas possibilitaram o aumento dos fluxos culturais e turísticos nas arenas turísticas que as abrigaram, localizadas nas seguintes cidades: Goiânia - GO, Guairá - PR, Marabá - PA, Campo Grande - MS, Marapanin - PA, Palmas - TO e Porto Seguro - BA. O acontecimento destes jogos incentiva a mobilidade das populações indígenas para outras localidades, bem como a inclusão social no que se refere ao acesso às viagens, a partir do emissivo de turistas de seus lugares de origem para outros lugares bem distantes.

Figura 04 - Imagem dos Jogos Indígenas /Arenas Turísticas

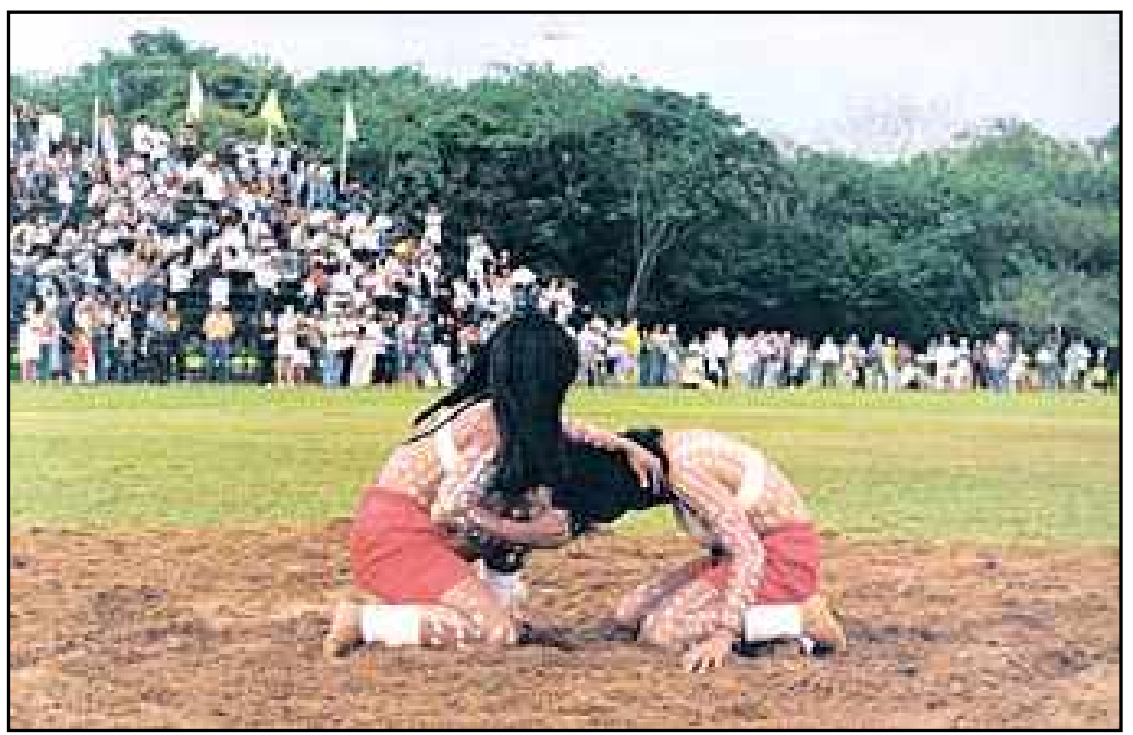

Fonte: www.funai.gov.br/ultimas notícias/2 semestre 2003. Consultado em 07/10/2005.

Atualmente, a mobilidade atinge todas as populações indígenas, mesmo aquelas que eram entendidas a partir do "mito do primitivo" e que ficavam inseridas no processo de reclusão, permanecendo presas em seus territórios e mantendo pouco contato com outras culturas. Entretanto, as populações indígenas ainda estão colocadas num contexto de exclusão social, tanto do ponto de vista do consumo quanto com relação às viagens. Os contatos estabelecidos entre essas diferentes culturas revelam, no entanto, que nenhuma sociedade se encontra num estágio mais avançado que outra.

Os jogos indígenas podem ser considerados como arenas turísticas que se tornaram atrativos turísticos para as populações indígenas e não-indígenas (nacionais e internacionais). Nesse sentindo: 
Ao reforçar a memória no presente, os jogos fazem uma ruptura com o passado através do fazer coletivo das coisas cotidianas. As modalidades inseridas nos jogos tais como arco e flecha, canoagem, carregar toras, natação, cabo de guerra são atividades cotidianas para a maioria das populações indígenas. Emprestados aos jogos, não deixam de ser coisas rotineiras, mas adquirem o sentimento de lembrarem a todos indígenas e não-indígenas dos modos de produção e de reprodução dos primeiros nos dias atuais. (AZEVEDO, 2005, p.08-09).

Assim, pode-se considerar que os jogos indígenas inserem-se na categoria "turismo indígena", uma vez que contribuem para o emissivo (atletas indígenas) de suas territorialidades para outras localidades, de modo que materializam a construção das arenas turísticas.

Figura 05 - Imagens dos Jogos das Populações Indígenas

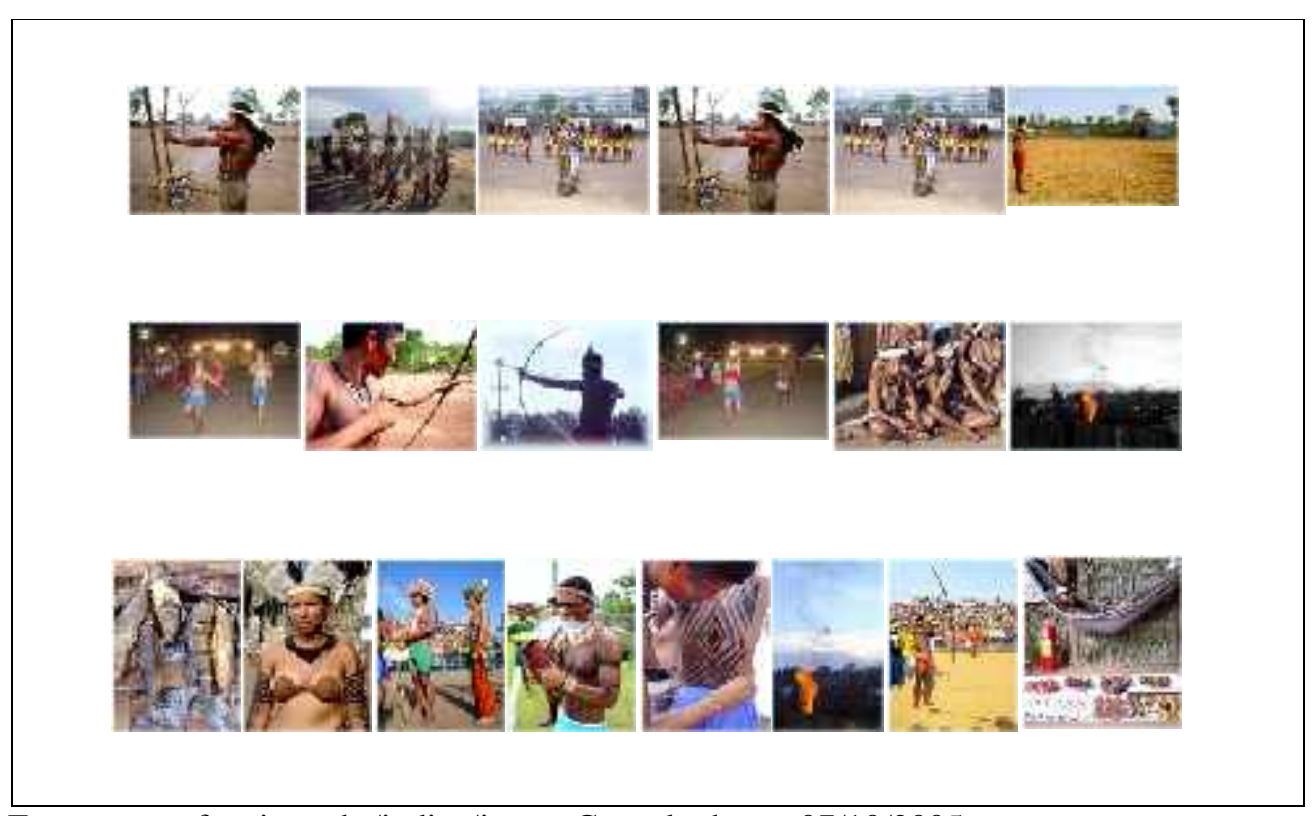

Fonte: www.funai.gov.br/indios/jogos. Consultado em 07/10/2005.

De um lado, as populações indígenas se identificam com os jogos indígenas e ganham notabilidade por meio do marketing de visibilidade e, de outro lado, os jogos indígenas contribuem para o fortalecimento do sentimento de coletividade de indivíduos e de lugares reais e imaginários. 
Os jogos indígenas em sua trajetória adquiriu modificações estéticas, visuais e mercadológicas. O "celebrar das tradições", hoje, se amalgama com o turismo, o marketing de visibilidade e com o gerenciamento econômico, sociocultural e simbólico visando à obtenção de inclusão social. (AZEVEDO, 2005, p.11).

Diante do exposto, fica evidente que as populações indígenas, ao se identificarem com o evento que está sendo analisado, participam da formação das arenas turísticas em várias localidades, compondo novas territorialidades turísticas. Realiza-se, assim, a constituição de novos segmentos turísticos, os quais podem ser identificados a partir dos usos dos termos territorialização, desterritorialização e reterritorialização.

Comumente, as populações indígenas, ao se deslocarem de suas territorialidades utilizando os vários meios de transportes (aviões, canoas e ônibus) para chegarem até as localidades dos jogos indígenas, passam por um processo de desterritorialização, pois entre a saída e a chegada de cada etnia de seus territórios-rede e/ou de suas espacialidades descontínuas realizam a viagem. Por exemplo, o percurso realizado pelos Krahô/Tocantins, Bororo/Mato Grosso, Guarani/São Paulo, Terena/Mato Grosso do Sul, Kalapalo/Xingu-Mato Grosso e Arawete/Pará até as cidades que sediaram os eventos pode ser definido como a ocorrência da desterritorialização.

A partir do momento em que os representantes das etnias mencionadas chegam às localidades dos jogos indígenas e instalam-se nos alojamentos/ocas, procuram se informar sobre os dias e os diferentes horários dos jogos e, assim, recebem informações sobre a territorialidade desconhecida entre os indígenas. Assim, à medida que o lugar torna-se familiar, pode-se afirmar que se inicia a reterritorilização. Nessa perspectiva, considerando-se a participação nas modalidades de esportes específicas de cada etnia, de acordo com aquelas realizadas nos calendários de rituais, pode-se dizer que o lugar escolhido para promover os jogos indígenas passa a adquirir um sentido de territorialização e, por isso, denomina-se de reterritorialização.

Os Krahô/Tocantins promovem as corridas de tora nas aldeias com o objetivo de cumprirem um calendário de rituais anual. A corrida de tora possui um significado específico para os Krahô; de forma simbólica, pode-se afirmar que eles estão carregando o corpo de um ente querido (ritual fúnebre) e levando-o de volta para a comunidade da aldeia. Por isso, os jovens e adultos entre dezessete (17) e trinta (30) anos de idade participam das corridas de tora. 
Assim, a reterritorialização também acontece em função do sentido simbólico que cada modalidade de esporte expressa para as etnias participantes, de modo que as competições esportivas das populações indígenas podem ser entendidas como carregadas de significados e de símbolos. Os indígenas que participam dos jogos utilizam as pinturas corporais e outros ornamentos (plumagem) seguindo a lógica dos rituais em suas comunidades; por isso os jogos indígenas possuem um conteúdo simbólico, sendo que cada etnia demonstra a sua cultura para o público presente.

O turismo indígena pode ser compreendido como um novo segmento turístico que está sendo organizado pelas associações e populações indígenas, o que contribui para que os turistas possam se interpretados no contexto da reterritorialização nas arenas turísticas. Vale destacar também que os jogos indígenas provocaram a construção de territórios por meio da mobilidade humana, aumentando o número de lugares em que as diversas etnias podem praticar a mobilidade social, o que pode ser confirmado pelos jogos indígenas ocorridos em várias cidades e Estados do país, evidenciando a formação de multiterritorialidades turísticas com um conteúdo de hibridização cultural.

\subsubsection{Turismo em territórios indígenas}

A discussão do turismo em territórios indígenas deriva da experiência que alguns autores propuseram em seus estudos no sentido de proporcionar o conhecimento da realidade dos fatos que ocorreram e ocorrem em diversos lugares, distantes uns dos outros, enquanto conteúdos expressivos e reveladores, possibilitando que os turistas infiltrem-se nos mais distintos locais em que as populações indígenas se encontram. Os turistas buscam estabelecer contatos com as populações indígenas com ou sem intermediários, revelando que mesmo diante da fragilidade da organização do turismo em territórios indígenas pode ser possível realizar as visitações.

O artigo de Grünewald (2001, p.127-148) intitulado "Turismo e o 'resgate' da cultura Pataxó" traz algumas contribuições para a análise do turismo em territórios indígenas. “A questão da mudança cultural é uma preocupação presente nos estudos em antropologia do turismo desde o surgimento desse campo de pesquisa, particularmente a mudança processada na sociedade hospedeira." (GRÜNEWALD, 2001, p.127). O destaque apontado pelo autor tem sido a ressalva indicada em diversos artigos sobre o turismo étnico, o qual está 
relacionado ao paradigma da aculturação; ou seja, o contato intercultural entre os turistas e a população hospedeira pode alterar os valores culturais tradicionais, acarretar na perda gradativa de uma cultura local ou promover uma...

[...] reviravolta na aparência dos nativos que passam a se exibir ocupando um lugar determinado no quadro geral de uma sociedade e - no caso aqui contemplado - através de sua atuação prática numa arena turística, isto é, num espaço social polissêmico onde ocorrem interações geradas pela atividade turística. (GRÜNEWALD, 2001, p.128).

Nota-se que o que está em discussão não é o processo de aculturação da sociedade hospedeira, mas o atual contexto em que os indígenas, enquanto grupos sociais, se encontram inseridos na modernidade. Observa-se também que o turismo pode trazer contribuições para a valorização cultural da sociedade hospedeira, partindo-se do pressuposto de que os sujeitos se recriam o tempo todo nas arenas turísticas, como é o caso específico dos índios Patáxos ${ }^{49}$, na Bahia.

Em 1961, foi criado o Parque Nacional do Monte Pascoal ${ }^{50}$, aumentando as dificuldades de sobrevivência dos índios, pois se estabeleceu a proibição da caça, da pesca, da coleta de frutos e do cultivo de suas terras. Uma vez vedados o uso da terra e, por conseguinte, a possibilidade de se tirar dela o sustento, buscou-se no artesanato uma forma de obtenção de renda.

Registrou-se um aumento da população da aldeia Coroa Vermelha durante o verão, época em que a região recebe um número maior de turistas, enquanto que no inverno ocorre o retorno de parte da população indígena para as suas aldeias de origem, o que sinaliza, então, uma mobilidade dos índios, que ocorre em função do turismo e tem por objetivo a comercialização do artesanato como complemento de renda.

\footnotetext{
49 “A atual população pataxó funda-se em 1861 a partir do aldeamento de índios (provavelmente das etnias pataxó, maxacali, botocudo, tupiniquim e camacã) que circulavam pelas matas litorâneas entre os municípios de Prado e Porto Seguro (litoral do extremo-sul da Bahia). Essa aldeia de Barra Velha, situada no limite meridional do município de Porto Seguro ficou sem assistência governamental desde sua criação, e os índios, em contato muito esporádico apenas com pescadores, pequenos comerciantes e fazendeiros até meados do século XX." (GRÜNEWALD, 2001, p.128).

${ }^{50}$ Nota do próprio autor: "Em 20 de abril, o Decreto 3.421, entre outras providências, altera o nome do Parque Nacional do Monte Pascoal para Parque Nacional e Histórico do Monte Pascoal." (GRÜNEWALD, 2001, p.128).
} 
No transcurso da história, desenvolveu-se o turismo local, que vem proporcionando a inclusão social dos índios Patáxos. À medida que esta localidade foi recebendo as formasconteúdo da modernidade, os índios pataxó foram fundando novas aldeias em lugares estratégicos para explorar o turismo e a venda do artesanato. Por ser uma região que recebe turistas brasileiros e estrangeiros, surgiu um mercado de artesanato indígena nas cidades, mantido por atravessadores.

Os turistas estrangeiros compram o artesanato no atacado e comercializam em seus países de origem, como uma forma de obter lucro e repor um pouco do que foi gasto durante a viagem.. Nesse sentido, registrou-se nestes últimos 20 anos um aumento do turismo na região de Porto Seguro, que recebe proporcionalmente mais turistas estrangeiros do que a cidade de Salvador. Os turistas que chegam até essas cidades utilizam diversos meios de transportes, entre os quais carros particulares, avião ou ônibus, procurando agito ou retiro nos distritos de Porto Seguro. ${ }^{51}$

Pelo número de turistas apresentado pelo autor, pode-se afirmar que o turismo desenvolvido nesta região da Bahia incorporou as aldeias indígenas Barra Velha e Coroa Vermelha. ${ }^{52}$ De acordo com as reflexões do autor, os índios pataxós aderiram ao termo baianidade, pois afirmam com orgulho que são índios baianos. De certa maneira, com a divulgação do turismo, envolvendo os empresários, o Estado e a mídia, a Bahia está entre os estados do Brasil que mais investe na divulgação do turismo, recebendo um grande número de turistas brasileiros e estrangeiros.

Contudo, ao optarem por praticar o turismo em Porto Seguro, os turistas não necessariamente relacionam tal viagem à visita aos índios patáxos. $\mathrm{O}$ interesse pela visitação à aldeia desta população é, em geral, despertado quando os turistas recebem informações dos guias turísticos, proprietários de pousadas ou agentes de turismo sobre o aspecto aculturativo do grupo étnico. Nessa perspectiva, o turismo tem contribuído para a valorização da cultura indígena, pois os índios pataxós conseguiram emergir de forma diferenciada na região em que

${ }^{51}$ Nota do próprio autor: "Arraial d'Ajuda, Troncoso e Caraíva - este último, vizinho da aldeia de Barra Velha." (GRÜNEWALD, 2001, p.131).

52 "Nem empresas turísticas nem os municípios de Santa Cruz e Cabrália e de Porto Seguro elaboram projetos turísticos envolvendo os pataxós, que acabam por se configurar como uma curiosidade a mais em passeios como à cruz da primeira missa, na Coroa Vermelha, à cidade de Porto Seguro, à noite na feira hippe da praça da Bandeira também nessa cidade, ou mesmo como atração final de um passeio recreativo a cavalo de Caraíva até a aldeia de Barra Velha - embora casa a aldeia já se configure como uma atração turística em si." (GRÜNEWALD, 2001, p.131-132). 
se encontram. O que os índios pataxós têm feito é a articulação de uma proposta de inclusão social numa cultura regional denominada de baianidade hegemônica, legitimando a nova cultura tradicional criada como autêntica e coerente no contexto da dinâmica de um turismo étnico emergente.

Com relação à temática "resgate de cultura e o índio turístico", Grünewald (2001, p.133) afirma que "Os elementos de cultura que são exibidos nas arenas turísticas são acionados pelos índios como suas tradições." Vale destacar que a cultura pode ser considerada como dinâmica, ou seja, passa por um processo constante de reformulação na sociedade contemporânea. Certamente, Hobsbawm (1997, p.09-23), ao abordar o tema "as invenções das tradições na sociedade contemporânea", estabelece uma distinção entre as sociedades complexas e as sociedades tradicionais, de modo que, no primeiro caso, pode-se afirmar que as tradições são inventadas e que, no segundo, as tradições seguem as regras da história e dos direitos naturais.

Atualmente, a concepção naturalista de tradição está sendo abalada pela modernidade, uma vez que esta penetra na vida cotidiana, moldando costumes e hábitos. $\mathrm{O}$ autor menciona que no processo de criação de tradições entre os patáxos tem-se uma orientação seletiva, baseada nas correntes culturais em fluxo translocal e nas co-tradições dos índios em geral como elemento constitutivo de uma determinada tradição. Existe, de certa maneira, dificuldade de se reconhecer um trabalho de invenção de tradições; por isso os índios pataxós preferem comunicar-se por meio do resgate da cultura, sendo que em outros casos se pode encontrar o termo valorização da cultura.

Os índios pataxós buscam se promover a partir do slogan "os índios do descobrimento". Esta invenção histórica constitui um marketing turístico e, ao mesmo tempo, um instrumento de tradição que se opõe à cultura não-indígena, de modo que a venda do artesanato sob a cruz da primeira missa contribui para o fortalecimento da idéia do índio turístico. As condições sob as quais se dispuseram a realizar as representações culturais contribuíram para o estabelecimento de um vínculo com o turismo, mas a venda do artesanato pode ser considerada a principal articuladora da criação do pólo turístico de Porto Seguro.

Como se sabe, nos últimos trinta anos, os contatos interétnicos e interculturais contribuíram para a reformulação do artesanato, adoção de técnica e de estética de índios de outras etnias e de não-índios (hippes). Assim, o resgate do artesanato perpassa pela elaboração de peças confeccionadas para o uso dos índios pataxós, sem necessariamente visar à 
comercialização. A evidente utilidade do artesanato para o resgate da cultura pode ser expressa na criação do Centro de Cultura de Barra Velha, local de exposição e não de comercialização. Assim, o projeto resgate visa à valorização da cultura, acompanhando as mudanças que aconteceram na confecção do artesanato, propondo em re-fazer o artesanato que os índios mais velhos faziam, numa lógica que não seja apenas a de comercialização, mas sim a da busca de imitações mais sofisticadas e próximas da cultura dos pataxós.

Logicamente, os turistas, ao se interessarem pelo artesanato, efetuam a compra com o objetivo de levar uma lembrança dos índios pataxós, que pode ou não representar a tradição indígena, delimitando sua fronteira étnica. É evidente que as aldeias localizadas próximas às cidades estão menos isoladas e com mais contatos interétnicos e interculturais, o que pode refletir na qualidade do artesanato.

Nesse aspecto, foi identificada a diferença entre o artesanato produzido pelos índios da aldeia de Barra Velha e pelos da Coroa Vermelha, sendo que esta última tem seguido o ritmo imposto pelos não-índios. A adoção de técnicas modernas vai gradualmente fazendo desaparecer as dificuldades para se confeccionar o artesanato (e uma conseqüente perda da tradição indígena), pois incluem a concorrência imposta pelos não-indígenas, que possuem fábricas de artesanatos na região. Portanto, quando estas duas espécies de experiências são contrárias, resta-nos o curso de subtrair uma da outra e propor uma análise para os dois lados. Assim, as variações no artesanato pataxó estão relacionadas à produção de objetos inventados para o consumo dos turistas e, portanto, para um consumo externo, que remete a etnicidades que estão sendo construídas.

No entanto, é necessário conhecimento sobre artesanato indígena para distinguí-los. Um turista pode, por exemplo, conhecer um artesanato como um objeto inventado, porém a razão mais evidente está na beleza do objeto inventado e este passa a ser fabricado com as exigências de um mercado específico. Os europeus sabem quais são as características dos artesanatos que são aceitos em seus mercados e, por conseguinte, exigem artigos com uma estética definida, sendo que os índios patáxos utilizam suas capacidades inventivas para atender esta demanda de mercado.

Além de oferecerem a arte e a inteligência, os índios (em geral), ao explorarem o turismo, desencadeiam uma tessitura de artes étnicas e turísticas, em que os artesanatos produzidos num lugar são consumidos em lugares distantes, recebendo imposições e regras de mercado externo. As artes étnicas e turísticas contribuem para o fortalecimento da identidade 
étnica, pois os índios estabelecem a distinção entre os objetos que pertencem à tradição e os que estão incluídos na cultura não-indígena. Tendo em vista o exposto, evidencia-se que as tradições inventadas pelos pataxós dão origem a novas tradições, e estas sustentam sua etnicidade diante do turismo, podendo interpretar de outra forma, isto é, que o turismo contribui para as tradições inventadas.

De certa maneira, outras duas tradições que podem ser levadas em consideração no que tange ao resgate da cultura dos índios pataxó são identificadas nos significados dos nomes indígenas e na própria língua. Os índios possuem nomes na língua indígena, mas nos seus registros de nascimento constam nomes não-indígenas, por isso há apenas o último sobrenome da etnia constando no Registro Cartorial. O turismo utiliza os nomes indígenas como um recurso de reforço da identidade na comercialização do artesanato, construindo, também, a fronteira étnica pataxó.

Certamente, pode-se perceber que a língua indígena pataxó encontra-se num estágio distinto de muitas outras etnias brasileiras, apresentando invenções que não condizem com a língua e a oralidade. Uma análise semelhante pode ser estendida às danças, às músicas e aos rituais. Por intermédio do projeto "Resgate no Dia do Índio" estão sendo realizadas representações da cultura na aldeia Coroa Vermelha e exibidas para os turistas, incluindo um roteiro de ecoturismo.

Vale destacar, ainda, que existe uma polêmica no tratamento teórico e metodológico do termo tradição, que possui duas atribuições: a autêntica e a inventada. A co-existência dessas atribuições mencionadas dá sentido mais coerente para as etnias que possuem contatos interétnicos, e argumentar que existe uma em detrimento da outra pode contribuir para o exagero do senso comum e para o empobrecimento das teorias.

As tradições que são criadas na arena turística podem ter um objetivo duplo: o primeiro está articulado à venda do artesanato para os turistas; e o segundo pode ser definido como estratégia de marketing, uma forma adotada para divulgar a venda do artesanato. Observa-se, ainda, que os índios procuram colocar em evidência um contraste de vivências cotidianas para os turistas, ao mesmo tempo em que acontece uma projeção no mercado do turismo. Todavia, o turismo em territórios indígenas ainda é visto como uma proposta pouco viável; isto é, constitui uma temática que é alvo de muitas polêmicas, daí tem-se a tessitura de críticas que caminham na direção oposta, negando o turismo em territórios indígenas. 
Logicamente, a experiência dos pataxós na oferta do turismo revela que a mercantilização a priori não está associada à destruição dos significados dos produtos culturais, pelo contrário, pode fazer emergir novos significados culturais. Por exemplo, um determinado objeto pode passar por um processo de mercadorização para atender ao mercado turístico, o que não implica na perda de sua autenticidade. Nas análises daqueles que estudam o novo contexto cultural, nada parece mais surpreendente do que a facilidade com que os índios tomam gosto pelas novas invenções. Estes valorizam os artesanatos com toda a incorporação das técnicas no processo de fabricação, como os turistas os fazem.

De certa maneira, analisando-se por intermédio de que meios os pataxós conseguiram tal prodígio, pode-se verificar uma constante influência dos meios de comunicação na formação de uma opinião interna e externa às comunidades das aldeias indígenas pataxós. Há, portanto, um processo de mudanças culturais no contexto do sentimento de satisfação no desenvolvimento das atividades turísticas. Parece que, no caso específico dos pataxós, o turismo tornou-se uma atividade econômica importante, a ponto de se sobrepor às demais atividades. Pode-se dizer que foi criada uma relação de dependência com o turismo (venda do artesanato) e, ao mesmo tempo, uma identidade que está sendo construída a partir do turismo. Por um lado, não existe um projeto de representação cultural que envolva encenações em datas que não sejam comemorativas e, por outro, a única representação é a do Ato do Descobrimento, que não faz parte de um projeto turístico. ${ }^{53}$

Se, em geral, o turismo étnico está relacionado à existência da fronteira étnica, esta por si só torna-se um atrativo turístico. No entanto, o que mais tem preocupado os analistas críticos do turismo em territórios indígenas são os efeitos resultantes das atividades turísticas no desmantelamento das tradições das comunidades hospedeiras. Porém, uma vez percebido que os princípios do turismo são diversos, tentar estabelecê-los constitui uma tarefa difícil. Para isto, trata-se de reunir numerosas experiências sobre o tema com o propósito de explicar a variedade de entendimentos existentes. Neste caso, os estudos empíricos específicos podem contribuir para uma apreensão mais aprofundada das críticas que estão sendo construídas.

\footnotetext{
${ }^{53}$ Nota do próprio autor: "Encenação (realizada todo dia 26 de abril [primeira missa] promovida pela Associação Cultural Arte e Ecologia de Santa Cruz Cabrália) ao ar livre na Coroa Vermelha sobre a chegada de Cabral, os primeiros contatos com os índios e a celebração da primeira missa." (GRÜNEWALD, 2001, p.142).
} 
As opiniões contrárias ao turismo em territórios indígenas repudiam essa proposição, alegando a concepção finalista de que se estaria caminhando para uma homogeneização da sociedade, incluindo as diversas etnias indígenas na perda sem fim de suas tradições. Neste caso, o turismo é visto como uma ameaça para a existência das populações autóctones. Entretanto, trata-se de uma visão unilateral, que não leva em consideração que as populações indígenas continuarão praticando a mobilidade, assim como a transposição da fronteira étnica. $\mathrm{Na}$ atualidade, a maior estabilidade da tradição está na ação de fazê-la emergir na interação social. A realização do turismo em territórios indígenas e a busca de autenticidade são, portanto, duas ocorrências inteiramente diferentes.

A proposição que coloca em evidência a perda de autenticidade no turismo étnico leva em consideração a concepção de aculturação, isto é, admite que no contato entre os turistas e os índios podem emergir novas tradições, que não pertencem às tradições anteriores e que, por conseguinte, amputam a autenticidade que a priori existia. Apesar disso, não se deve concluir que o turismo introduz somente elementos culturais negativos na localidade em que se realiza. Pelo contrário, a idéia de descaracterização não passa de uma concepção mumificada e/ou descontextualizada da realidade dos índios na sociedade contemporânea; assim, o turista que espera ver o índio turístico a partir das interpretações culturais que não possuem mais uma validade para a atualidade está construindo um falso ideal do outro turístico.

O olhar do turista pode ser aquele já pré-construído, que define os índios como exselvagens, ex-primitivos, povos recentemente aculturados, primitivo performativo, índios modernos. A situação seria mais grave se os índios trabalhassem nas fazendas ou nas fábricas das cidades ou até mesmo se estivessem na condição de desempregados, sem a obtenção de uma renda. E prosseguindo-se um pouco mais com essa comparação, torna-se evidente que o esclarecimento do processo histórico a que os índios foram submetidos ainda faz-se necessário.

O artigo de Guimarães et. al. (2004, p.01-15), publicado nos anais do VIII ENTBL, realizado na cidade de Curitiba - PR, contribui para a aproximação da abordagem do tema, pois apresenta uma discussão sobre a realidade brasileira e a de outros países: 
Comparativamente a grande parte dos países que possuem povos indígenas (nativos, tribais, ou não), o Brasil não possui um número significante destes povos organizados para o turismo. Pode-se dizer, entretanto, que nos últimos sete anos houve uma movimentação ao nível do governo federal e das próprias comunidades indígenas no sentido de planejar o turismo em suas áreas. (GUIMARÃES et. al., 2004, p.01).

Os turistas, descontentes com a oferta de pacotes turísticos formatados por empresas especializadas, em face das viagens para os diversos lugares para apreciarem as atrações oferecidas, acabam escapando do turismo de massa e procurando com espontaneidade "uma cultura indígena”. De um lado, chegam até às aldeias indígenas localizadas nas proximidades das médias e pequenas cidades do Brasil e, de outro, chegam por meio do contato direto com as comunidades indígenas.

Configura-se que nem todas as etnias estão organizadas em associações para articularem projetos voltados para o planejamento da recepção de turistas. Logicamente, esta questão nem sempre envolve negociação de pacotes por meio de agências de turismo ou empresas do gênero; estas, quando percebem que o negócio é lucrativo, têm o propósito de serem mediadoras. As estratégias adotadas para evitar o conflito entre os índios e as empresas são diversas, dentre estas as que possibilitam resultados concretos perpassam pelas associações indígenas e pelas comunidades locais (das aldeias).

As experiências dos povos indígenas (nativos, tribais ou não) com o turismo revelam histórias específicas. Em alguns casos o turismo é visto como uma solução, enquanto que em outros recebe uma avaliação pouco positiva, em função dos efeitos causados na economia de subsistência das comunidades locais, além da degradação do meio ambiente, que tem a sua causa nos grandes empreendimentos construídos. Pode-se verificar a seguir casos específicos de implicações do turismo em territórios indígenas:

- Aborígenes (Austrália): Representação da cultura para turistas. A paisagem natural como um atrativo turístico, às vezes recebendo um destaque maior do que os Aborígenes. (RYAN e HUYTON, 2002. p.631-647).

- Ainu (Ilha de Hokkaido, Japão): Contato pessoal com os turistas. São vistos como parte da paisagem local. Muitas vezes, os turistas desconhecem o passado histórico (colonial) dos nativos e acreditam que os Ainu ainda vivem como no passado, demonstrando pouco conhecimento de sua cultura. (GUIMARÃES, 2004, p.05). 
- Maori (Rotura, Nova Zelândia): Licenciamento para guias turísticos desde 1911. A organização do turismo encontra-se com um histórico de vivência. O turismo tem contribuído para o aumento da renda das comunidades locais. Venda de artesanato como um recurso de reforço da identidade étnica. (GUIMARÃES, 2004, p.03).

- Kamchatka (Sibéria): Projetos dirigidos pelas comunidades locais têm contribuído para a geração de renda e a valorização da cultura. Os guias locais desenvolvem um papel importante nas atividades turísticas. (www.survival.es. Consultado em 10/07/2005).

Mohawk (Canadá): Ampliação de um campo de golfe sobre cemitérios mohawk. (LEAL, 2004, p.1-4).

- Chhetri (Nepal Ocidental): Exclusão das comunidades locais e erosão nas áreas costeiras próximas aos complexos turísticos. (LEAL, 2004, p.1-4).

Samburu (Reserva de Sahara, no Kênia): Desprezo das comunidades locais. (LEAL, 2004, p.1-4).

- Masai (Tanzânia): Exclusão das áreas importantes para pastagens do rebanho. Impacto na economia de subsistência sem a apresentação de uma proposta alternativa para as comunidades. Transformação de suas terras "em áreas de conservação para a caça esportiva". (LEAL, 2004, p.1-4).

- Atacameño (Chile): Cria riqueza e permite diminuir a emigração dos jovens para as cidades. Valoriza as culturas indígenas e aporta maior reconhecimento. Fomenta o desenvolvimento sustentável. (SEGOVIA, 2004, p.1-5).

- Indígenas da Venezuela: Denominam o turismo indígena como o novo imperialismo. Há registros de turistas estrangeiros nas comunidades indígenas. Ainda não há uma organização. O Estado tem uma postura contra o turismo em territórios indígenas. (LEAL, 2004, p.1-4).

Comunidades Indígenas do México: Os estados de Chiapas, Oaxaca, Yucatán, Estado de México, Guerrero, Michoacán e Quitana Roo estão analisando a possibilidade de organizar o turismo comunitário indígena; as discussões estão sendo organizadas pelo Instituto Quintanarroense de la Cultura.

(www.prodigyweb.net.mx/iqcdir/SalaPrensa/site.htm. Consultado em 03/10/2005).

- Oaxaca (México): Comunidades Indígenas estão produzindo artesanato para o mercado interno e para a exportação, recebendo por peças produzidas. Empresas 
provenientes dos Estados Unidos estão monopolizando a produção local. (COHEN, 2001, p.378-398).

A realidade internacional do turismo em territórios indígenas permite construir uma análise do processo de organização e, inclusive, uma avaliação acerca de cada situação; e, em seguida, pode ser possível perceber o envolvimento das comunidades locais. Todavia, a maioria expressiva dos exemplos mencionados aponta que o turismo pode ser considerado como uma atividade econômica relevante para as comunidades locais. Nos lugares em que a organização do turismo leva em conta as suas comunidades, as contradições seguem a tendência da redução.

Com relação ao turismo em territórios indígenas brasileiros, é notória a ausência de uma proposta concreta que viabilize sua organização. De certa maneira, a iniciativa por parte do governo federal pode ser considerada recente, pois se iniciou a discussão com o objetivo de elaborar concepções e técnicas para atender à demanda do mercado internacional, acreditando que a procura seria grande, a partir do atendimento da oferta do mercado.

"Formou-se em 1997 o Grupo Técnico de Coordenação do Ecoturismo para a Amazônia Legal (GTC Amazônia), com apoio da Funai, da Embratur, promovido pelo Ministério do Meio Ambiente e executado pela Associação Brasileira de Ecoturismo ECOBrasil.” (GUIMARÃES et. al., 2004, p.03-04). O resultado da proposta concreta foi a construção do "Manual Indígena de Ecoturismo", publicado em 1997, que serviria como documento básico para nortear a organização do turismo em territórios indígenas. Esta proposta pode ser considerada construída com pouca participação dos povos indígenas, tendo como objetivo principal criar uma alternativa econômica por intermédio do turismo, em que as comunidades indígenas seriam as responsáveis pela sua gestão.

Destaca-se que a discussão foi pautada a partir do termo ecoturismo, sendo que as comunidades indígenas demonstraram interesse na implementação deste segmento, seguindo as orientações apontadas no referido documento. Nesta lógica, a seguir, são apresentados exemplos de experiências com o turismo envolvendo algumas populações indígenas, visto que a análise de cada uma delas contribui para a compreensão do quadro turístico em territórios indígenas do país: 
- Pataxó (Bahia): Recepção de turistas nas aldeias Coroa Vermelha e Barra Velha; a atividade principal tem sido a venda do artesanato. Os pataxós destacam-se como os indígenas que estão mais organizados para o turismo no Brasil. Em seu território, a venda do artesanato constitui uma importante atividade econômica; menciona-se até que foi construída uma relação de dependência com o turismo.

- Kaiapó (estados Mato Grosso e Pará): Projeto de Construção de um Hotel Luxuoso para potencializar o turismo. Alojamentos dos turistas - Suítes isoladas, blocos de apartamentos e bloco de alojamento coletivo. (www.embratur.gov.br/br/kaiapo. Consultado em 10/09/2004).

Karajá (Ilha do Bananal, Tocantins): Projeto Canguçu /ONG (Ecológica). Tem um projeto voltado para o ecoturismo; Hotel luxuoso; Projeto de construção de um aeroporto internacional (obra foi interrompida pelo Ibama); Os índios Karajá fazem representação cultural para turistas, como aquela realizada na ocasião da visita do Príncipe Charles (Reino Unido) ao Brasil. (www.ecologica.org.br/ilha/ecih_nuc.htm. Consultado em 29/01/2002).

- Krahô (estado do Tocantins, Brasil): Feira Krahô de Sementes Tradicionais realizada desde o ano de 1997 (I Feira) e até o ano de 2004 (VI Feira), contando com participantes indígenas e não-indígenas (brasileiros e estrangeiros). Há registro de freqüência de turistas nas aldeias - Manoel Alves, Santa Cruz, Pedra Branca, Cachoeira e na Kapey. Contato pessoal entre os turistas, associações indígenas, Funai e as comunidades indígenas. (OLIVEIRA, 2005).

- Guarani, Aldeia Boa Vista (Estado de São Paulo): “Com cerca de 130 índios, a aldeia é liderada pelo cacique Altino dos Santos, 55, que está em Ubatuba desde 1970.” Tem um projeto de implantação do turismo ecológico. Existe uma articulação entre índios Guarani e a prefeitura de Ubatuba. O território Indígena Guarani recebe turistas de uma forma espontânea, isto é, a organização do turismo ainda se encontra em sua fase inicial. (www.ubatuba.gov.br. Consultado em 04/10/2005).

- Centro Cultural Guateka (Mato Grosso do Sul): Em função da união dos nomes das etnias Guarani, Terena e Kaiwá, como ideário, deve ser um instrumento de resgate, preservação e produção cultural tradicional da população indígena, utilizando o turismo como precursor dessas mudanças. (CABREIRA e MORETTI, 2005, p.2550). 
- Pontyguara (Litoral Norte do Estado da Paraíba): Por volta da década de 80, o Governo do Estado da Paraíba lançou um programa de desenvolvimento tendo como campo de ação as regiões litorâneas que possuem um alto potencial para a prática do turismo. O complexo turístico implantado pela PBTUR incorporou a cidade de Baía da Traição - PB como um dos lugares para estação de veraneio. (www.socioambiental.org/pib.epi/pontyguara/tur .shtm).

- Apinayè (Estado do Tocantins): Recebem turistas de forma espontânea, os quais chegam por intermédio de contatos com as comunidades indígenas das aldeias e com associações indígenas. A venda de artesanato é feita na Associação PenpKàk. Construiu-se a Casa da Cultura para expor os artesanatos e fazer a recepção dos visitantes. Oferece oficinas de artesanato para os jovens (homens e mulheres) aprenderem com os/as índios/as mais velhos. (Pesquisa de Campo, 2004, 2005 e 2006).

- Krikati, Gavião, Canela Apaniekra e Canela Ramkokamekra (Estado do Maranhão): Recebem turistas sem que tenham uma organização para o turismo. A venda de artesanato para os turistas atende aos mercados local e regional, nacional e internacional, de modo que por meio das associações a população indígena Krikati valoriza a produção do artesanato como uma forma de estimar a cultura indígena. (Pesquisa de Campo, 2004, 2005, e 2006).

Cabe destacar que os resultados práticos de projetos turísticos em territórios indígenas não ocorreram nem estão ocorrendo com facilidade, pois nem todas as etnias estavam e estão organizadas para o turismo. Logicamente, as orientações específicas para implantar o turismo e o apoio técnico podem ser considerados como elementares. Apenas algumas etnias conseguiram realizar discussões neste sentido, ficando mais evidente as expectativas do que as experiências com o turismo.

O turismo em territórios indígenas que está acontecendo no Brasil não pode ser identificado a partir do conteúdo do Manual Indígena de Ecoturismo. O documento foi elaborado com uma participação mínima das populações indígenas e, portanto, não representa a realidade destas populações e de suas experiências com o turismo. 


\subsection{ATRIBUIÇÃO DE NOMES AOS VISITANTES (AOS TURISTAS) NAS ALDEIAS KRAHÔ}

Ao chegarem a uma aldeia Krahô, os visitantes, ou turistas, são recebidos no pátio, onde são apresentados pelo cacique à comunidade. Caso estejam fazendo o primeiro contato pessoal com os índios, são convidados a serem batizados. No batismo, recebem um nome Krahô da comunidade da aldeia, o que pode ser considerada uma forma de aproximação entre os índios e os turistas.

Depois da visita à primeira aldeia e do batismo, o nome recebido pelo visitante é informado às comunidades de outras aldeias. Nestas, o turista vai identificando seus "parentes" e construindo a sociabilidade, a partir das relações de "parentesco" e de amizade. De acordo com o depoimento do informante Getúlio Krahô, a prática de atribuir nomes aos Kupẽ (povos estranhos) pode ser considerada antiga, já que foi ensinada pelos mais velhos aos mais novos. Caso aconteça qualquer coisa com os turistas, os Krahô ficam sabendo, pois há a identificação do nome Krahô.

O pahi (Cacique) recebe todos os Kupẽ na sua comunidade, não discriminando ninguém, tendo o compromisso de apresentá-los para a comunidade. O primeiro a receber a notícia da visitação é o pahi (Cacique), que tem a responsabilidade de ficar sabendo o tempo de permanência do turista na comunidade, o seu objetivo durante a visitação e no que pode contribuir para a comunidade durante a sua estadia. O pahi (cacique) da aldeia explica para a comunidade que é importante atribuir os nomes Krahô aos visitantes, sendo que cada turista é escolhido por um membro da comunidade e este ganha o nome. Depois de receber um nome Krahô, faz-se o ritual de batismo, na condição "fillho". O índio que deu nome chama o visitante pelo nome Krahô no meio do pátio, anunciando-o várias vezes, para evitar que o mesmo nome não seja atribuído para mais de um turista. 
Os nomes têm como referência as metades Wakmeye (lado leste do pátio) e Katamye (lado oeste do pátio) (metades sazonais), as metades Khöikateye (Wakmeye) e Harãkateye (Katamye) (metades de idade), as metades Khöirumpekëtxë (Wakmeye) e Harãrumpekëtxë (Katamye), as metades Hëk (Wakmeye) e Krókrók (Katamye) e as metades Tép (Wakmeye) e Teré (Katamye).

A estrutura social e política Krahô se define pelas metades sazonais e o mesmo procedimento é usado na organização dos rituais. Os visitantes, ao receberem os nomes Krahô, podem ser considerados inseridos na estrutura social e política e por isso, se posicionarão do lado leste ou do lado oeste do pátio.

Nos grupos rituais que participam do Khetwaye, os Kupẽ (“civilizado") ocupam uma posição no extremo sul do lado leste do pátio e seu opositor Krẽ (Piriquito-estrela) tem seu lugar no extremo sul do lado oeste do pátio, "que parecem ser de fora e não tem vergonha de pedir, os Mekhen, que fazem coisas erradas nos ritos, parecendo, portanto, gente que não tem familiaridade com os costumes Krahô" (MELATTI, 1978, p.340). Tanto os Kupẽ quanto os Hotxua fazem brincadeiras engraçadas nos rituais, pois os Kupẽ dançam com o objetivo de imitar os índios e os Hotxua dançam fazendo imitações dos Kupẽ.

Com a realização dos grupos rituais, a comunidade traz alegria para a aldeia, sendo que, de certa maneira, os Hotxua fazem o papel dos Kupẽ, embora os visitantes (Kupẽ) participem das brincadeiras como observadores e sejam entendidos como estranhos, denominação dada pela existência da fronteira étnica entre índios e não-índios. Certamente, o que chama a atenção no grupo ritual Khetwaye é a encenação que os índios fazem representando os Kupẽ, em que estes são vistos como estranhos e, portanto, não conhecem a cultura dos Krahô. Ou seja, na realização deste ritual os Krahô reforçam a identidade e a fronteira étnica. (Figuras 06 e 07) 
Figura 06 - Grupos Rituais KHETWYE

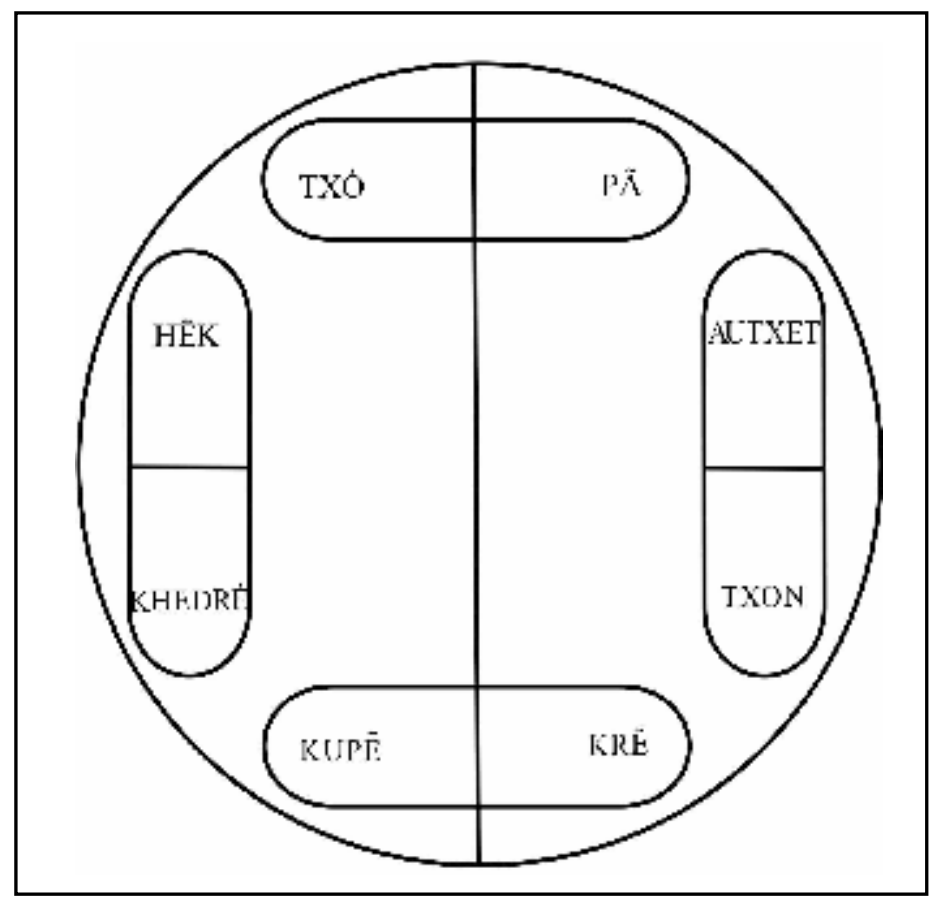

Fonte: (MELATTI, 1978, P.339), Projeto Gráfico Vanderlei M. Oliveira.

Figura 07 - Posição dos Grupos Rituais que participam do KHETWYE

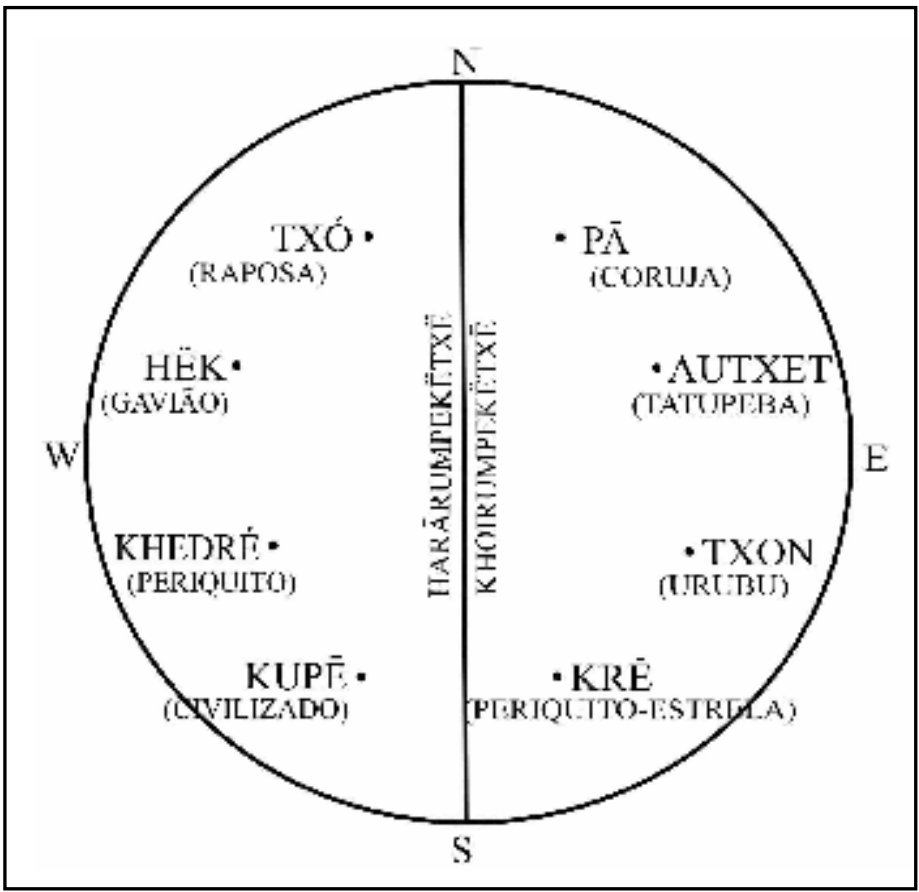

Fonte: (MELATTI, 1978, P.89) 
Lévis-Strauss (1989, p.190) afirma:

Essa universalização totêmica não abala somente as fronteiras tribais formando o esboço de uma sociedade internacional, ela também ultrapassa, às vezes, os limites da humanidade, num sentido não mais sociológico, mas biológico, quando os totêmicos são aplicáveis aos animais domésticos.

Os Krahô podem ser considerados dentro dessa lógica em que os nomes indígenas são atribuídos aos não-indígenas, o que configura a universalização e a particularização. Nesse sentido:

O espaço é uma sociedade de lugares nomeados tal como as pessoas são pontos de referência dentro de um grupo. Os lugares e os indivíduos são igualmente designados por nomes próprios, que, em circunstâncias freqüentes e comuns em muitas sociedades, podem ser substituídos uns pelos outros. (LÉVIS-STRAUSS, 1989, p.190).

Assim, o visitante (ou turista), ao receber um nome da comunidade indígena Krahô, passa a ser identificar com o lugar e com os indivíduos da população indígena Krahô.

De acordo com o Grupo Ritual Khetwaye, os Krahô estabelecem fronteira étnica nas relações interétnicas e interculturais, principalmente quando recebem os turistas no Ka (pátio da aldeia) e lhes atribuem os nomes Krahô de identificação. No presente estudo, entende-se que o nome Krahô concedido ao turista pode ser considerado um passaporte de entrada para o território indígena Krahô no seu primeiro contato com essas comunidades indígenas.

\subsection{EFEITOS E IMPACTOS DO TURISMO}

Atualmente, os efeitos e os impactos do turismo indígena (emissivo) e do turismo em territórios indígenas (receptivo) podem ser analisados em duas direções opostas. De um lado, o turismo indígena não tem os efeitos e os impactos no mesmo plano, este é praticado pelos próprios índios. De outro, o turismo em territórios indígenas não pode ser entendido como uma atividade econômica (mercadológica) que se sobrepõe às demais, ou seja, se deve colocar como destaque a relação entre turistas e comunidades locais. Os efeitos e os impactos do turismo podem ser revelados quando os turistas (não-índios) buscam a "universalização" da cultura indígena, acreditando que todas as etnias são iguais e que elas vivem da mesma 
maneira, o que deve ser evitado, pois os povos indígenas são diferentes entre si e diferentes dos não-indígenas.

Os turistas alimentam expectativas que são oriundas do (des)conhecimento do histórico dos indígenas. Eles esperam encontrar nas aldeias índios puros e frágeis, acreditando que eles não foram tocados pela modernidade. Pode ser considerada uma grande ilusão para os turistas quando eles esperam encontrar culturas autênticas, e esta tendência, bem como as várias necessidades da vida humana, os submetem necessariamente aos negócios e às ocupações, e nem por isso as populações indígenas deixam de ter a cultura inserida num contexto de transformação constante.

Nesta lógica, a modernidade indicou o caminho da mescla de culturas como o mais apropriado para a humanidade. Esta tendência arrasta todos os povos indígenas, mesmo aqueles com pouco contato regular com os não-indígenas. Nesse sentido,

O contato vem em primeiro lugar, historicamente. Em seguida, há o jogo de distinção que produz as diferenças culturais. Cada coletividade, no interior de uma situação dada, pode ter a tentação de defender sua especificidade, fazendo um esforço através de diversos artifícios para convencer (e se convencer) que seu modelo cultural é original e lhe pertence. $\mathrm{O}$ caráter da situação determinará se o jogo de distinção levará a valorizar e a acentuar tal conjunto de diferenças culturais mais do que outro. (CUCHE, 2002, p.143).

O fim adequado de tudo isto diz respeito a um contínuo desenvolvimento reflexivo do entendimento da relação dos indígenas com a modernidade. Entre os efeitos e os impactos do turismo em territórios indígenas pode-se destacar que o contato pessoal entre os indígenas e os não-índios pode influenciar e trazer mudanças para as partes envolvidas. "As culturas nascem de relações desiguais." (CUCHE, 2002, p.143). De modo que há tentativas permanentes de se manter a hierarquia entre as culturas. As hierarquias existem porque as culturas podem ser consideradas interdependentes.

Logicamente, os efeitos do turismo em territórios indígenas não podem ser analisados na perspectiva das interpretações redutoras, elegendo-se, por exemplo, um grupo social mais forte (o dos turistas) e um grupo social mais fraco (o dos índios).

$\mathrm{Na}$ medida em que a cultura real só existe se produzida por indivíduos ou grupos que ocupam posições desiguais no campo social, econômico e político, as culturas dos diferentes grupos se encontram em maior ou menor posição de força (ou fraqueza) em relação às outras. Mas, mesmo o mais fraco não se encontra jamais totalmente desarmado no jogo cultural. (CUCHE, 2002, p.144). 
As considerações finais deste capítulo podem ser consideradas limitadas diante da complexa realidade em que a organização do turismo em territórios indígenas se encontra. De um lado, aponta-se o turismo como uma alternativa para promover o desenvolvimento local e, de outro, elenca-se algumas questões pertinentes sobre o turismo, assim como os seus efeitos positivos e negativos.

No território indígena Krahô a experiência da organização do turismo, assim como do desenvolvimento dos demais projetos, tem seguido a lógica da estrutura econômica e social Krahô. A participação das comunidades indígenas contribui no sentido de propor que a organização do turismo no território indígena Krahô seja de responsabilidade das comunidades indígenas Krahô e das associações indígenas Krahô. Os efeitos positivos do turismo em territórios indígenas estão relacionados ao aumento da renda para as comunidades e para as associações indígenas, pois se tratam de oportunidades para a venda do artesanato para os turistas, o que contribui para a construção e a elevação da auto-estima dos indígenas. Concomitantemente, os efeitos negativos do turismo podem ocorrer no sentido de saturar um ponto geográfico de visitação, como, por exemplo, uma área de lazer de um rio, um ribeirão (cachoeira), o que pode tornar este lugar inviável para os índios e para os turistas.

Portanto, o turismo em territórios indígenas tem pontos positivos e negativos. Contudo, os efeitos negativos do turismo podem ser evitados, propondo-se orientações acerca dos lugares que podem ser visitados e daqueles que devem ser evitados pelos turistas nos territórios indígenas.

O capítulo três (03) apresenta a análise dos projetos Krahô e do turismo. Nele, pretende-se estabelecer a relação entre os Projetos Krahô e a organização do turismo em territórios indígenas. 


\section{CAPÍTULO 3 - PROJETOS INDÍGENAS KRAHÔ, DESENVOLVIMENTO SÓCIO-ESPACIAL E A ORGANIZAÇÃO DO TURISMO}

Este capítulo propõe uma análise dos projetos que estão sendo desenvolvidos nas comunidades indígenas Krahô, destacando as ações da Kapey-União das Aldeias Krahô na elaboração de planos para obter financiamentos junto aos órgãos do governo federal e estabelecer acordos e contratos de parcerias com a Embrapa e Universidades, tendo em vista que o turismo se encontra organizado dentro da estrutura social e econômica Krahô. Entre os anos de 1997 e 2004, durante a realização das Feiras Krahô de Sementes Tradicionais, foi possível identificar os Krahô integrados aos turistas, demonstrando os projetos que estão sendo desenvolvidos, apresentando os resultados positivos dos projetos com financiamentos (BNDES, PDPI e Fundação Banco do Brasil) e os relativos à pesquisa da EmbrapaCerrados $^{54}$.

Nesta lógica, o debate sobre o turismo indígena e o turismo em territórios indígenas está sendo construído a partir do estudo de caso dos povos indígenas Krahô e de seus projetos que visam à inclusão social das comunidades indígenas com a inserção de esquemas de financiamentos e de pesquisa, envolvendo instituições de pesquisa e financeiras, com uma interlocução entre pesquisadores, indigenistas e as comunidades das dezoito (18) aldeias, as quais estão associadas à Kapey. O desenvolvimento sócio-espacial está sendo levado em consideração, uma vez que congrega todas as aldeias e envolve a participação e colaboração das comunidades indígenas do início até a finalização dos projetos.

Como se sabe, pode ser considerada recente a iniciativa da criação do PDPI da Amazônia Legal Brasileira, pois surgiu a partir da avaliação do histórico da participação dos povos indígenas brasileiros em linhas de financiamentos do governo federal. Até então, sua

\footnotetext{
${ }^{54}$ Conforme os resultados apresentados pela Embrapa (2000) no Relatório Parcial do Projeto intitulado "Etnobiologia, Conservação de Recursos Genéticos e Bem-Estar Alimentar em Comunidades Tradicionais". Este projeto permitiu o desenvolvimento dos subprojetos: I) Coleta, Caracterização e Conservação de Germoplasma da Comunidade Indígena Krahô; 2) Reintrodução, Introdução e Translocação de Germoplasma na Comunidade Indígena Krahô; 3) Identificação nas Interrelações entre o Saber Tradicional e o Científico na Agricultura; e 4) Manejo de Sistemas Agrícolas da Área Indígena Krahô.
} 
participação pode ser considerada pouco significativa, sendo fruto da inexistência de políticas públicas setoriais para os povos indígenas.

O PDPI teve as suas regras definidas no ano de 1999 e divulgadas entre os anos de 2000 e 2001. ${ }^{55}$ As comunidades indígenas da Amazônia Legal Brasileira, por intermédio de suas organizações, encaminharam os seus projetos para o PDPI, reivindicando recursos financeiros para desenvolvê-los em três dimensões prioritárias: Valorização Cultural, Desenvolvimento de Atividades Econômicas Sustentáveis e Proteção das Terras Indígenas. Este programa financia projetos e subprojetos planejados e executados com a participação das comunidades e organizações indígenas. É uma forma de incentivar novas propostas que possam resultar na melhoria da qualidade de vida das populações indígenas, garantido a sustentabilidade econômica, social e cultural das comunidades. No estado do Tocantins foram aprovados dois $(02)^{56}$ projetos, os quais estão sendo desenvolvidos junto aos povos indígenas Krahô.

A Coordenação das Organizações Indígenas da Amazônia Brasileira (COIAB), por sua vez, foi fundada em 19 de abril de 1989 e tem por objetivo articular as organizações indígenas. Reúne em sua base política setenta e cinco (75) organizações, divididas em 31 regiões e representando 165 povos dos estados da Amazônia Legal Brasileira. Neste aspecto, o PDPI é resultado das ações da COIAB, que tem proporcionado o fortalecimento da

${ }^{55}$ Almeida (2003, p.73-81), no seu artigo intitulado "Um balanço dos projetos enviados ao PDPI", publicado na Revista Anthropológicas do Programa de Pós-Graduação em Antropologia da Universidade Federal do Pernambuco, coloca que "A concepção de projetos como uma lista de compras, arraigada nas práticas assistencialistas da FUNAI, que historicamente deu exemplos aos índios de todo o país que um projeto era aquela lista de enxada, terçado e forno de torrar farinha pode ser mais claramente visualizada em um último exemplo concreto. Esse exemplo é de um projeto de proteção de uma terra indígena, onde o único bem descrito em seu entorno era uma Toyota. Esse projeto, não sem motivo, foi elaborado por uma liderança indígena que é também funcionário da FUNAI, sendo evidente que não passava de pretexto para adquirir o carro, que era necessário para a referida proteção, mas não bastava para garanti-la" (p.80).

${ }^{56}$ Projeto 01: Escola Catxêkwyj - Vivência Agroambiental, a qual foi construída na sede da KapeyUnião das Aldeias Krahô, localizada nas proximidades do Riozinho, como é denominado o Ribeirão Riozinho pelos índios Krahô. Entre as aldeias que estão mais próximas da Kapey se pode mencionar: Aldeia Santa Cruz, Aldeia Manoel Alves Pequeno, Aldeia Pedra Branca e Aldeia Campo Lindo. Contudo, esta escola atende a todas as aldeias Krahô com projetos de extensão e formação de agentes ambientais, de agentes de saúde, agentes comunitários, entre outras denominações. Projeto 02: Aprovado pela Associação Makrare que representa a Comunidade Indígena da Aldeia Nova, o qual tem por objetivo a valorização cultural dos Krahô por meio da realização de rituais associando-os com a mitologia da origem da agricultura, promovendo o desenvolvimento das atividades econômicas sustentáveis, entre elas: agricultura, manifestações culturais e, por último, potencializa o turismo em territórios indígenas organizado por comunidades indígenas (Pesquisa de campo, 2004, 2005 e 2006). 
"autonomia" dos povos indígenas por intermédio de suas organizações. Parece, assim, que a organização dos movimentos sociais indígenas vincula-se à ideologia do desenvolvimento com base local.

No Brasil, o debate sobre o desenvolvimento com base local pode ser considerado recente, já que passou a ser adotado no final da última década do século XX. Rodrigues (2003) ressalta que existe a possibilidade de se estabelecer relação entre os movimentos sociais e a teoria do desenvolvimento sustentável, como algo quase simultâneo. O Fórum das Nações Unidas sobre Meio Ambiente e Desenvolvimento /Agenda 21 (1992) promoveu discussões sobre políticas públicas nos contextos internacional, nacional e local. As nações do mundo aceitaram adotar uma abordagem equilibrada e integrada das questões sobre meio ambiente e desenvolvimento, perpassando pelo engajamento das comunidades tradicionais.

O capítulo 26 do Documento do Fórum das Nações Unidas sobre Meio Ambiente e Desenvolvimento" ${ }^{57}$ /Agenda 21 (1992), intitulado "Reconhecimento e Fortalecimento do Papel das Populações Indígenas e suas Comunidades", traz propostas voltadas para o desenvolvimento sustentável das populações indígenas e suas comunidades. Os objetivos e as atividades, para serem implementadas, necessitam da cooperação plena das comunidades indígenas, dos governos e das organizações intergovernamentais. Logicamente, foi uma forma adotada para possibilitar aos povos indígenas a participação e o usufruto da plenitude dos direitos humanos e das liberdades fundamentais, sem práticas discriminatórias.

Os projetos que estão sendo desenvolvidos no território indígena Krahô estão inseridos na lógica do Fórum das Nações Unidas sobre Meio Ambiente e Desenvolvimento /Agenda 21 (1992), reunindo parcerias com o governo federal, instituições internacionais, universidades, governo do estado do Tocantins e prefeituras locais (ver Tabela 02).

${ }^{57}$ CONFERÊNCIA DAS NAÇÕES UNIDAS SOBRE MEIO AMBIENTE E DESENVOLVIMENTO (1992, RIO DE JANEIRO). A resolução nº 441228 da Assembléia Geral da ONU, de 22/12/1989, estabelece uma abordagem equilibrada das questões relativas ao meio ambiente e ao desenvolvimento: Agenda 21. Brasília: Câmara dos Deputados, Coordenação de Publicações, 1995 (Série Parlamentar, $\left.\mathrm{n}^{0} 56\right)$. 
Tabela 02 - Projetos Desenvolvidos pela KAPEY- União das Aldeias Krahô

\begin{tabular}{|l|l|}
\hline \multicolumn{1}{|c|}{ Projetos } & \multicolumn{1}{c|}{ Parcerias } \\
\hline $\begin{array}{l}\text { 1. Levantamento Geral das Condições de Saúde } \\
\text { da População Indígena Krahô }\end{array}$ & $\begin{array}{l}\text { Projeto executado entre os anos 1995/1996 } \\
\text { (FUNASA) }\end{array}$ \\
\hline $\begin{array}{l}\text { 2. Vigilância e Controle da Terra Indígena Krahôo } \\
\text { Projeto executado entre os anos 1995/1996 } \\
\text { (MMA) }\end{array}$ \\
\hline $\begin{array}{l}\text { 3. Projeto Conservação e uso de Recursos } \\
\text { Genéticos na Terra Krahô }\end{array}$ & EMBRAPA - Cerrados (PESQUISA) \\
\hline $\begin{array}{l}\text { 4. O Projeto Escola Catxêkwyj - Vivência Agro- } \\
\text { Ambiental }\end{array}$ & $\begin{array}{l}\text { PDPI - Projetos Demonstrativos dos Povos } \\
\text { Indígenas (FINANCIAMENTO) }\end{array}$ \\
\hline $\begin{array}{l}\text { 5. Projeto de Desenvolvimento Integrado Social } \\
\text { Krahô (PDISK) }\end{array}$ & $\begin{array}{l}\text { BNDES- Banco Nacional Desenvolvimento } \\
\text { Econômico e Social (FINANCIAMENTO) }\end{array}$ \\
\hline $\begin{array}{l}\text { 6. PPP/PNUD - Plantas e Frutas dos Cerrados - } \\
\text { Programas de Pequenos Projetos }\end{array}$ & $\begin{array}{l}\text { Conservação das Plantas e o Aproveitamento } \\
\text { das frutas do Cerrado }\end{array}$ \\
\hline $\begin{array}{l}\text { 7. Projeto Resgate, Valorização e } \\
\text { Comercialização do Artesanato Krahô }\end{array}$ & $\begin{array}{l}\text { FUNDAÇÃO BANCO DO BRASIL S/A } \\
\text { (FINANCIAMENTO) }\end{array}$ \\
\hline
\end{tabular}

Fonte: Pesquisa de Campo, 2004, 2005 e 2006.

\subsection{PROJETO CONSERVAÇÃO E USO DE RECURSOS GENÉTICOS NA TERRA KRAHÔ}

Este projeto tem por objetivo contribuir para a recuperação da agricultura tradicional dos povos indígenas Krahô e dos seus valores. Pode ser considerado um projeto maior que norteia outros projetos menores, perspectivando a valorização da cultura.

O interesse pela efetivação e construção de propostas de parcerias vem resultando na sustentação dos projetos Krahô. A parceria com a EMBRAPA - Empresa Brasileira de Pesquisa Agropecuária, por exemplo, está permitindo conservar os valores culturais dos povos indígenas Krahô. A Kapey tem autonomia para articular e formalizar parcerias com órgãos desta natureza. Nessa perspectiva, a gestão do turismo no território indígena Krahô segue a lógica dos projetos que já estão sendo desenvolvidos (financiamentos e pesquisa).

O turismo em territórios indígenas pode ser considerado um segmento turístico emergente no Brasil. As populações indígenas, por intermédio de suas associações e comunidades, recebem os turistas, os quais, muitas vezes, estão vinculados aos projetos que estão sendo desenvolvidos e/ou interessados em conhecer os projetos Krahô. 
Atualmente, este projeto está subdividido em cinco (05) projetos menores: Coleta, Caracterização e Conservação de Recursos Genéticos; Inter-relação entre o Conhecimento Tradicional e o Conhecimento Científico; Introdução, Reintrodução e Translocação de Materiais Genéticos na Terra Krahô; Uso, Manejo e Conservação de Solos na Terra Krahô; Documentação e Difusão do Projeto. A seguir, pode-se verificar a atuação de cada um desses subprojetos.

\subsubsection{Coleta, Caracterização e Conservação de Recursos Genéticos}

Por meio deste projeto, foram realizados o levantamento e a caracterização da flora no território indígena Krahô. Este projeto também tem o intuito de fazer a coleta e a conservação de materiais genéticos e de recuperar aqueles que, porventura, forem considerados perdidos. O acordo firmado (contrato assinado) entre a EMBRAPA e os povos indígenas Krahô prevê que os materiais genéticos são dos povos indígenas Krahô, e que para eventual repasse a terceiros faz-se necessária uma autorização dos povos indígenas Krahô.

\subsubsection{Inter-relação entre o Conhecimento Tradicional e o Conhecimento Científico}

Os interesses culturais podem traduzir-se na produção e não-produção. Nesse sentido, este projeto levantou alguns elementos e questões sobre o conhecimento tradicional dos povos indígenas Krahô, principalmente no que diz respeito à alimentação e à agricultura. Como se sabe, nas roças existem diversas espécies de batatas, mandiocas e bananas, entre outros alimentos. A agricultura tradicional Krahô constitui-se numa ruptura com a atual agricultura moderna e industrial. Esse conhecimento pode reforçar a necessidade e a valorização da cultura Krahô.

\subsubsection{Introdução, Reintrodução e Translocação de Materiais Genéticos na Terra Krahô}

No quadro das mudanças históricas, os povos indígenas Krahô perderam materiais genéticos. Neste sentido, este projeto prevê o resgate, a translocação e a introdução de materiais genéticos no território Krahô. 


\subsubsection{Uso, Manejo e Conservação de Solos na Terra Krahô}

Este projeto prevê a análise dos solos na Terra Krahô e a definição de suas deficiências e potencialidades. Procura, ainda, identificar a maneira adequada de garantir a conservação e o manejo auto-sustentável, contribuindo para a melhoria da agricultura.

\subsubsection{Documentação e Difusão do Projeto}

Reúne os documentos de todo o Projeto Krahô como material de registro sob a forma de documentação áudio-visual (vídeo, fotografia e desenhos). O material de registro permite a produção de outros materiais de divulgação.

\subsection{PROJETO ESCOLA CATXÊKWYJ - VIVÊNCIA AGRO-AMBIENTAL ${ }^{58}$}

É por meio da prática que os povos indígenas buscam o aprendizado. Os mais velhos têm uma importância fundamental na transferência dos valores culturais, principalmente no que se refere aos ensinamentos relacionados à agricultura tradicional. A Escola Catxêkwyj Vivência Agro-Ambiental é um espaço de ensinamento e de aprendizagem. A sede desta escola está localizada no território dos povos indígenas Krahô e o projeto é desenvolvido no próprio território, contribuindo para a valorização cultural. Os índios mais velhos ensinam para os alunos indígenas jovens o conhecimento da agricultura tradicional, o que constitui uma forma de valorizar a cultura indígena Krahô e também de acompanhar as técnicas que estão sendo difundidas na atualidade.

\footnotetext{
${ }^{58}$ PDPI- Projetos Demonstrativos dos Povos Indígenas (FINANCIAMENTO) aprovado pela KapeyUnião das Aldeias Krahô; com os recursos deste projeto foi construída a Escola Catxêkwyj - Vivência Agroambiental, Biblioteca da Escola Catxêkwyj, acervo de vídeos sobre a população indígena Krahô e outras etnias, assim como material de registro, documentários sobre a agricultura, meio ambiente e desenvolvimento sustentável que estão sendo desenvolvidos em outras etnias (Pesquisa de Campo, 2004, 2005 e 2006).
} 


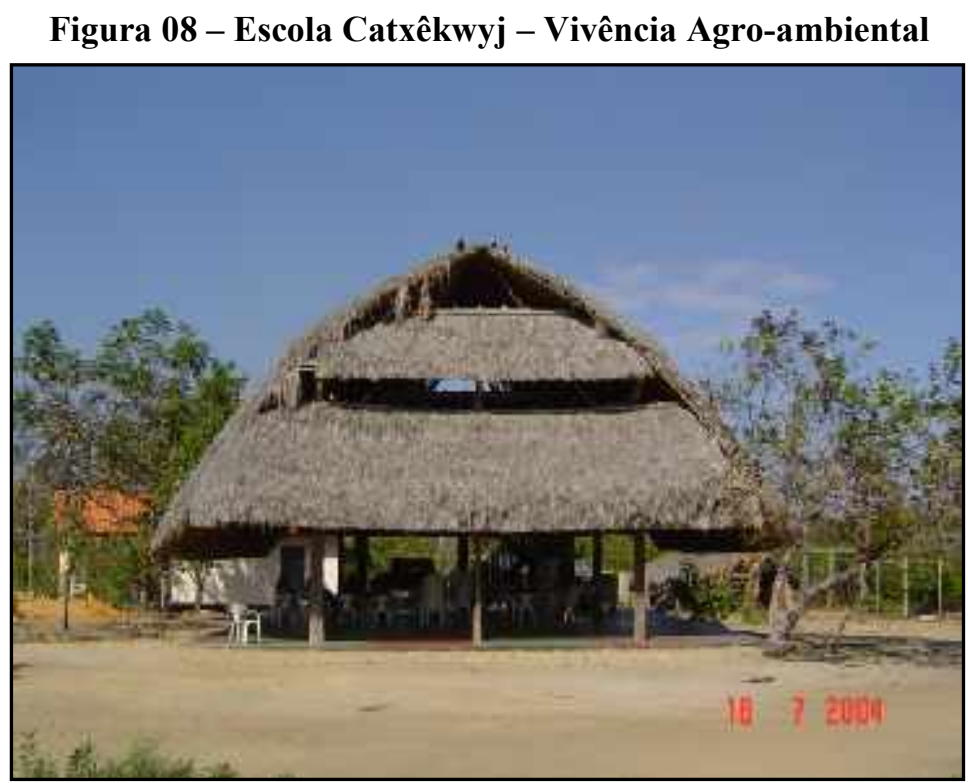

Fonte: Autor, 2004.

As oficinas podem ser ministradas por técnicos que possuem formação específica, como, por exemplo, por Engenheiros Agrônomos, Engenheiros Florestais, Nutricionistas, Geógrafos, Antropólogos, Zootecnistas, Biólogos e Nutricionistas. A Escola Catxêkwyj Vivência Agro-Ambiental, segundo os povos indígenas Krahô, é aberta, isto é, seus projetos são discutidos sob a forma de oficinas. As observações e a realização de experiências fazem com que os professores e os alunos indígenas permaneçam no ambiente da escola, sendo que os experimentos são feitos nas plantações próximas ao local onde esta se encontra.

A população indígena Krahô procura conhecer também projetos implantados em outras localidades. Para isto, os representantes da Kapey realizam viagens para trazer experiências novas de plantios tradicionais. Existe uma preocupação com as atuais mudanças na sociedade de uma forma geral, por isso os Krahô buscam aprender tanto com os índios mais velhos quanto com os povos não-indígenas. As inovações tecnológicas estão sendo produzidas por todos e os povos indígenas têm as suas tecnologias, assim como os povos nãoindígenas, por isso faz-se necessária a troca de experiências. 


\subsection{PROJETO DE DESENVOLVIMENTO INTEGRADO SOCIAL KRAHÔ (PDISK) ${ }^{59}$}

Pode-se dizer que os interesses políticos estão mudando, uma vez que antes dificilmente seria aprovado um projeto que previsse os próprios povos indígenas como administradores de recursos. Atualmente, as populações de índios podem contar com financiamentos do governo federal, como, por exemplo, o concedido pelo BNDES, que aprovou o Projeto de Desenvolvimento Integrado Social Krahô - PDISK. Este projeto permitiu a viabilização das seguintes iniciativas: Escola Catxêkwyj - Vivência AgroAmbiental; Armazém Comunitário; Casa de Beneficiamento de Matéria-Prima; Casa de Hospedagem de Instrutores; Instalação de Energia Alternativa/Solar; Captação de Água; Casa da Rádio Comunitária; Pontes e Estradas que dão acesso às aldeias; Escritório da Kapey; Casa do Correio; Casa do Artesanato; e Oficina para manutenção dos veículos. Vale destacar também que o financiamento concedido pelo BNDES possibilitou, ainda, a compra de veículos (camionetes e trator), de equipamentos e de artigos de escritório (computadores e outros equipamentos) para a Rádio Comunitária e para a Kapey (vide Anexo).

\subsection{PROJETO RESGATE, VALORIZAÇÃO E COMERCIALIZAÇÃO DO ARTESANATO KRAHÔ}

Os povos indígenas Krahô produzem artesanatos de qualidade e utilizando diversos materiais; tais artigos estão sendo comercializados por atravessadores nos grandes centros

\footnotetext{
59 "O projeto consiste na construção de um complexo arquitetônico com várias unidades dispostas em círculo, reproduzindo uma aldeia tradicional Krahô. As construções são em estilo 'tradicionalmente moderno', conservando as características tradicionais das construções indígenas, utilizando-se de materiais rústicos que recebem tratamentos com modernas técnicas, aumentando a durabilidade e segurança. Esse complexo está localizado em local mais ou menos central da Terra Indígena Krahô e beneficiará toda a população da etnia, que totaliza aproximadamente duas mil pessoas, habitando em dezoito aldeias. Todo o projeto está sendo pensado e discutido de forma a transmitir modelos autosustentáveis de exploração do meio ambiente, em várias áreas, como: habitação, saneamento, captação e distribuição de água, geração de energia, educação, saúde, cultura e lazer, agricultura, psicultura, meliponicultura, apicultura, criação de pequenos animais, manejo de caça, beneficiamento de matérias-primas dos cerrados, turismo ecológico, entre outros, de forma que os habitantes das aldeias possam apropriá-las. O local é utilizado por toda a população Krahô, que ali vai para fazer participar de competições esportivas, assistir vídeos educativos e culturais, etc., evitando-se assim os deslocamentos às cidades próximas, onde são discriminados e explorados." (Relatório do Projeto de Desenvolvimento Integrado Social Krahô - PDISK, 2005, s/n).
} 
urbanos. Há, no entanto, a necessidade de se fazer o levantamento quantitativo e qualitativo do artesanato para se verificar os que estão sendo produzidos e os que não são mais confeccionados, para, assim, se recuperar a arte de fazer e de refazer o artesanato considerado perdido.

O levantamento dos principais artesãos da comunidade indígena Krahô permitirá que se realize o resgate e a recuperação dos artesanatos, pois os mais velhos poderão ministrar oficinas na Escola Catxêkwyj - Vivência Agro-Ambiental, passando o seu conhecimento e a sua prática para os mais jovens. Dessa maneira, serão criadas as condições para que o artesanato Krahô possa ser comercializado no Brasil e no exterior.

Tendo em vista o desenvolvimento dos diversos projetos no território indígena Krahô, pode-se afirmar que as perspectivas do desenvolvimento sócio-espacial (com base local) são promissoras, sobretudo porque as comunidades indígenas estão envolvidas nos referidos projetos, sabem como surgiram, conhecem os problemas pertinentes às suas etapas de elaboração, assim como as condições em que os planos de gestão se encontram. Ou seja, há participação nas tomadas de decisões do início ao final dos projetos. Nesse sentido, a discussão do turismo articulada com o desenvolvimento local permite avançar nas reflexões sobre o turismo nos territórios indígenas.

Os projetos que estão sendo desenvolvidos pela Kapey representam atrativos turísticos, pois valorizam a cultura da população indígena e fazem como que os Krahô tenham orgulho de apresentar aos turistas as novidades conquistadas nas últimas décadas. Como se sabe, para que os territórios indígenas sejam visitados fazem-se necessárias a elaboração de planos e a permissão da Funai e da população indígena, que se encontra organizada nas comunidades das dezoito (18) aldeias. A população indígena Krahô, assim como as outras associações indígenas, está organizada politicamente, tendo a Kapey como entidade representativa.

\subsection{O TURISMO NO TERRITÓRIO INDÍGENA KRAHÔ}

Depois de realizar a pesquisa de campo nas comunidades Krahô, foi possível identificar a realidade do turismo em territórios indígenas como uma nova segmentação turística no estado do Tocantins. Nesta lógica, das dezoito (18) aldeias Krahô, apenas quatro 
(04) são visitadas com mais freqüência por turistas: a aldeia Manoel Alves, a aldeia Pedra Branca, a aldeia Santa Cruz e a aldeia Cachoeira. Estas quatro (04) aldeias são também as mais antigas e as que possuem um número maior de habitantes. Suas comunidades preservam a realização de cerimoniais, apresentando um calendário anual de rituais, de modo que as manifestações culturais indígenas são valorizadas pelos turistas que chegam até as aldeias com o intuito de vivenciar o seu cotidiano.

Os índios são escolhidos pela comunidade para organizarem o acontecimento de um determinado ritual. Alguns meses antes, eles iniciam os esforços para captar os recursos necessários para a compra dos materiais que serão consumidos pela comunidade indígena que se encontrará reunida para participar dos rituais. Entre os participantes dos rituais estão os representantes da aldeia responsável pela organização dos cerimoniais, os índios de outras aldeias e os não-índios. Os turistas chegam ao território Krahô por intermédio de contatos com as organizações não-governamentais, com as associações indígenas e/ou com a comunidade de uma aldeia específica.

O levantamento de proposições em torno do objeto de estudo "turismo em territórios indígenas" deve ser pensado do ponto de vista da organização participativa, respeitando-se todas as etapas. Na pesquisa de campo realizada no território Krahô entre os anos de 2004, 2005 e 2006, foi possível identificar que a discussão sobre o turismo nas terras habitadas por esta população foi iniciada em 2000 pela Secretaria Estadual de Indústria, Comércio e Turismo do Estado do Tocantins. Nesta ocasião, foi ministrada uma oficina sobre o que é turismo e promovida uma visita exploratória de três (03) dias nas aldeias mais próximas da Kapey. Em seguida, concluiu-se o relatório sobre as potencialidades turísticas do território Krahô.

A partir de então, foram criadas expectativas, por um lado, acerca da organização do turismo e, por conseguinte, da identificação, organização e divulgação das potencialidades turísticas do estado do Tocantins e, por outro, acerca do aumento da renda das famílias indígenas das aldeias visitadas. A análise que se pode fazer dos resultados das ações da Secretaria Estadual de Indústria, Comércio e Turismo do Tocantins se restringe à metodologia utilizada, que possibilitou o rápido reconhecimento das potencialidades turísticas do território Krahô. 
De acordo com o Diretor do "Setor de Turismo", nem todos os Territórios Indígenas das Etnias do Tocantins podem ser classificados como turísticos. Embora o território indígena Krahô não conste no roteiro turístico do Estado do Tocantins, os Krahô recebem turistas em épocas de temporadas de férias, ou seja, nos meses de janeiro, fevereiro e julho. Os pequenos grupos de turistas chegam até a cidade de Itacajá (TO) carregando mochilas, barracas, colchonetes e o material necessário para permanecerem acampados por alguns dias. São provenientes, em geral, das regiões Sudeste e Centro-Oeste do Brasil e de alguns países europeus, como França, Itália e Alemanha.

As comunidades Krahô autorizam a visitação ao território indígena mediante o pagamento de determinado valor em dinheiro ou em mercadoria. Portanto, os acordos entre os índios e os turistas envolvem diferentes formas de pagamento. Embora os índios prefiram receber em dinheiro, na prática o pagamento pode acontecer de outra forma. Se o valor determinado é recebido em dinheiro, este é logo destinado à compra de mercadorias; em seguida, ocorre a divisão dos produtos adquiridos segundo a lógica da estrutura econômica e social Krahô, de modo que toda a comunidade é contemplada com a renda do turismo.

$\mathrm{Na}$ atualidade, os turistas estão em busca de opções de viagens para localidades que apresentem paisagens diferenciadas, mesmo que estas incorporem conteúdos artificializados. A hipótese de que os turistas estão cansados de viajar para locais que oferecem sempre as mesmas cenas é um sinal de que as comunidades tradicionais possuem potencialidades para o turismo voltado para pequenos grupos de visitantes.

Pode-se considerar que o ecoturismo, enquanto uma modalidade de turismo, vem ganhando forte dimensão e buscando a sua expansão nos lugares de natureza conservada. Devido às perspectivas de crescimento da procura pelo ecoturismo nas mais diversas localidades, estão ocorrendo discussões teóricas e metodológicas que têm por objetivo possibilitar o avanço de estudos científicos pautados nas experiências realizadas de ecoturismo e no conteúdo histórico dos debates sobre o meio ambiente e o desenvolvimento sustentável.

Logicamente, a realização do turismo em territórios indígenas ainda pode ser considerada uma questão que exige bastante pesquisa. Nesse sentido, o artigo de Rodrigues (2003, p.29-45) intitulado "Ecoturismo - limites do eco e da ética" traz algumas questões que são elementares e polêmicas: 
O ano de 2002 foi eleito o Ano Internacional do Ecoturismo, objetivado pelo fato de ser este segmento um dos que tem apresentado maior crescimento em escala mundial, tendo em vista o grande interesse despertado pelo movimento ambientalista. Foi um ano também emblemático na história das discussões de cunho ecológico, pelo fato de termos completado dez anos pós Eco-92, momento de grande ebulição em torno da Cúpula Mundial Rio + 10 em Johannesburgo, África do Sul. (RODRIGUES, 2003, p.29).

De acordo com o pensamento da autora, pode-se fazer considerações positivas sobre a realização do referido evento, principalmente levando-se em conta a divulgação do ecoturismo e o fomento de uma atividade econômica que está associada às preocupações referentes à conservação da natureza. $\mathrm{O}$ termo ecoturismo propagou-se rapidamente, passando a ser usado em diversos países, o que permite afirmar que se tornou mais uma linguagem da globalização. Esse uso indiscriminado evidencia...

[...] que o prefixo eco tem sido utilizado como bandeira em todo movimento e idéia que tenha um apelo ambientalista, nem sempre com real comprometimento com a essência do conceito. Em outras palavras, isto significa que tem sido usado indiscriminadamente, com fins legítimos ou espúrios. (ROGRIGUES, 2003, p.29).

Atualmente, pode-se ter a impressão de que a natureza conservada está associada à palavra Éden, termo bíblico que possui um sentido simbólico. O início da humanidade remonta à idéia representativa da existência primeira do Éden, de modo que seria a condição básica para a projeção do ser humano num mundo com regras estabelecidas, as quais estavam delimitadas com manifestações opostas, de um lado o bem, e de outro o mal.

Deus teria colocado o homem no Jardim do Éden para cultivá-lo e guardá-lo. Seria um jardim florescente, situado na terra do sol nascente. Nele vicejava a árvore da vida e da imortalidade, localizado no meio do jardim e ao alcance do homem. Nele florescia também a árvore do conhecimento do bem e do mal (supostamente uma macieira), portadora do fruto proibido. ${ }^{60}$ (RODRIGUES, 2003, p.30).

A ascensão do ecoturismo pode estar relacionada às representações simbólicas do mundo ocidental que foram constituídas ao longo do processo histórico e sofreram influência do discurso religioso. Nesse sentido, o termo "paraíso como o Jardim do Éden” está associado ao termo "natureza conservada", que, por sua vez, está articulado ao "mito do eterno retorno",

${ }^{60}$ Ver também o artigo: AOUN, S. "Paraíso à vista - os jardins do éden oferecidos pelo turismo." In: RODRIGUES, A. A. B. (Org.). Ecoturismo no Brasil: possibilidades e limites. São Paulo: Contexto, 2003. p.15-27. 
daí a relevância da dimensão que o ecoturismo ganhou nas últimas décadas do século XX, assim como nestes primeiros anos do século XXI.

Outro destaque pode ser dado ao fenômeno da urbanização, que atingiu principalmente as médias e grandes cidades. Estas passaram, então, a carecer de uma natureza conservada. Portanto, o espaço urbano cada vez mais artificializado pode ser o responsável pela crise existencial do ser humano e por fatores como o alto índice de depressão. É, ainda, responsável pelos grandes investimentos públicos e privados que têm sido feitos neste início de século e de milênio na tentativa de se buscar soluções para os problemas surgidos com tal artificialização.

Para se curar dos sintomas das tensões cotidianas enfrentadas nos grandes centros urbanos, o ser humano tem a necessidade de retornar aos locais onde a natureza encontra-se conservada. Nesse sentido, vale acrescentar que o contato com as comunidades locais pode fazer bem para a saúde, repondo a energia necessária para um corpo e uma mente saudáveis. Para praticar essa terapia, a reunião harmoniosa estabelecida entre a natureza conservada e o cotidiano das comunidades locais tem sido o suporte para a elaboração de programas de ecoturismo, que, enquanto conceito, pode ser assim explicado:

Ecoturismo é uma atividade econômica, de baixo impacto ambiental, que se orienta para áreas de significativo valor natural e cultural, e que através das atividades recreacionais e educativas contribui para a conservação da biodiversidade e da sociodiversidade, resultando em benefícios para as comunidades receptoras. A International Ecoturism Society define sucintamente ecoturismo como uma viagem responsável para áreas naturais que pretende conservar o meio ambiente e apoiar o bem-estar das populações locais. (RODRIGUES, 2002, p.31).

Ainda refletindo sobre o ecoturismo, podem surgir dúvidas, tais como: Onde praticar o ecoturismo? É possível haver uma harmonia entre natureza conservada e ecoturismo? Como evitar os impactos ambientais e culturais na natureza conservada e nas comunidades aí localizadas? Parece que responder estas questões tem sido uma tarefa difícil para os pesquisadores; apesar disso, pode-se notar que o caminho das discussões está sendo pautado e norteado pelas perspectivas do desenvolvimento sustentável. No entanto, numa concepção mais radical, o conceito de desenvolvimento sustentável também passa por uma análise crítica, sendo questionado a partir dos seus próprios princípios. Nesse sentido: 
É necessário também rever o conceito de desenvolvimento sustentável, cujos princípios norteadores são: eficiência econômica, conservação da natureza, princípios éticos que culminam na justiça social e na eqüidade em se tratando da população anfitriã. Gostaria de receber informações de apenas um empreendimento onde estes paradigmas estão sendo respeitados. (RODRIGUES, 2003, p.32).

De acordo com o pensamento da autora, para se encontrar os limites do ecoturismo faz-se necessário analisar os principais segmentos envolvidos, assim como os interesses que foram e estão sendo por eles criados. Para isto, tem-se, de um lado, o segmento ambientalista, o setor empresarial, o Estado, o Ecoturista, as instituições de ensino e, de outro, as comunidades hospedeiras. Estes apontamentos realizados por Rodrigues (2003, p.32-44) serão apresentados numa síntese:

a) $\mathrm{O}$ segmento ambientalista: envolve um discurso construído pelos ambientalistas objetivando propor novos modelos de desenvolvimento de atividades econômicas sustentáveis, encontrando-se nas Organizações Não-Governamentais os principais meios de divulgação e de construção da proposta de ecoturismo. O quadro das ONG's envolvidas com projetos ecoturísticos revela o quanto foi assimilada a questão da natureza conservada e do desenvolvimento sustentável. Logicamente, está explícita também a produção e reprodução do capital, daí as condições para a sobrevivência das ONG's na sociedade capitalista.

b) O setor empresarial: este impulsiona o mercado do ecoturismo, ficando atento aos movimentos do mercado e sempre propondo novas ofertas de roteiros ecoturísticos, perspectivando capturar as tendências recentes de sua expansão. Com a concepção de que o ecoturismo pode ser uma atividade de reduzido impacto ambiental e cultural, a natureza conservada e as comunidades indígenas têm sido as principais bases de sustentação do processo de divulgação desta atividade turística. $\mathrm{Na}$ obsessão pelo crescimento econômico empresarial, "Os folhetos vendem imagens paradisíacas de vegetação exuberante, inesgotáveis mananciais, pássaros exóticos, mamíferos em extinção, flores raras, comunidades indígenas 'quase' intocadas, rico e criativo artesanato" (RODRIGUES, 2003, p.33). Também com essa preocupação, pratos típicos são criados e trazem em suas denominações referências à natureza conservada e à culinária local. A expansão dos negócios empresariais encontra no ecoturismo as condições para o crescimento "desmesurado", por isso faz-se necessário refletir sobre a 
idéia de natureza conservada, comunidades indígenas, pequenos grupos de turistas, “apreciação da natureza” e valorização cultural. Do conjunto destas proposições pode-se encontrar o levante das contradições que estão sendo criadas na formulação dos discursos e da prática do turismo.

c) O Estado: pode ser considerado "o maior parceiro nos projetos de ecoturismo e de outros setores rotulados de turismo com base local" (RODRIGUES, 2003, p.34). Existem conflitos de interesses entre o Estado e as ONG's na busca de alternativas, o que se evidencia quando as ONG's reivindicam a atuação do Estado no cumprimento de seus deveres por meio do fortalecimento dos movimentos sociais, fato que incomoda o Estado. "Assim o Estado tem que essencialmente permitir, facilitar e apoiar sempre a comunidade, não se isentado de suas obrigações fundamentais." (RODRIGUES, 2003, p.35).

d) O Ecoturista: o turista que possui interesse pela natureza conservada busca no ecoturismo uma forma de concretizar as suas representações simbólicas. Dessa forma, são vários os grupos de turistas interessados, cada um apresentando um perfil diferenciado; entre tais grupos, pode-se citar os pesquisadores ecoturistas, os ecoturistas pesquisadores, os ecoturistas naturalistas e os ecoturistas casuais. ${ }^{61}$

f) As instituições de ensino: considerando-se as instituições de ensino superior na lógica do ensino, da pesquisa e da extensão, estas muito podem contribuir para a investigação do ecoturismo nas localidades que apresentam potencialidades turísticas, perspectivando desenvolver pesquisas locais de apoio às comunidades e construir críticas necessárias por intermédio da pesquisa-ação e da pesquisa-participante.

g) Comunidades hospedeiras: as comunidades hospedeiras têm uma importância fundamental para o ecoturismo, de modo que pensar no ecoturismo como uma atividade econômica sustentável pode ser possível apenas se proporcionar retorno financeiro para elas. "Assim, o plano Estratégico da Conservação Mundial da IUCN (International Union for Conservation of Nature), já em 1980 assinalava a importância do vínculo entre a administração da área protegida e as atividades econômicas das comunidades

${ }^{61}$ Esta pode ser a lógica dos turistas que chegam até as comunidades indígenas Krahô, objetivando participar das Feiras Krahô de Sementes Tradicionais, assim como das manifestações culturais Krahô. Logicamente, o Território Indígena Krahô pode ser considerado nos sentidos econômico, político, cultural e ambiental. Por isso, possui potencialidade para a segmentação turística denominada de ecoturismo. 
locais.” (RODRIGUES, 2003, p.36). Neste sentido, as comunidades locais são as principais articuladoras, precisando estar munidas das informações que estão pautadas nas propostas de organização (com concepções e técnicas) sobre o turismo. Trata-se de refletir sobre o turismo, destacando-se os pontos positivos e os negativos que podem dele resultar em curto, em médio e em longo prazo. "Deve-se usar, portanto, uma linguagem adequada que possa ser assimilada, porém vale ressaltar que cada comunidade é diferente e deve ser entendida como única. Há que ter respeito pelas especificidades, não havendo modelos a imitar.” (RODRIGUES, 2003, p.37).

\section{Pode-se citar o exemplo do...}

[...] programa de ecoturismo de Mamirauá, no estado do Amazonas, o qual é apontado como modelo. Este programa, em vigência de 1999 a 2002, envolve atualmente (outubro de 2001) quatro comunidades, das quais somente 25 famílias encontram-se engajadas. O ecoturismo representa uma atividade econômica complementar, importante no período de entressafra da pesca. (RODRIGUES, 2003, p.38).

As comunidades avaliaram o programa de ecoturismo depois de um ano de visitação, chegando à conclusão de que as atividades turísticas proporcionaram renda via prestação de serviços e venda de artesanatos. "A estrutura receptiva está por conta da pousada Uacari, que oferece dez suítes que podem acomodar confortavelmente até 3 pessoas. A renda média anual das famílias é de 1.600 reais.” (RODRIGUES, 2003, p.39). Esta renda obtida por meio do programa de ecoturismo tem caráter complementar e, portanto, apóia as atividades tradicionais das famílias, fator que deve ser levado em conta no desenvolvimento dos projetos de ecoturismo. Ou seja, as atividades turísticas não devem sobrepor as demais atividades, já que se isso acontecer o próprio ecoturismo pode chegar ao fim.

A ética constitui um elemento importante a ser levado em consideração na elaboração de programas de ecoturismo, principalmente quando envolve as comunidades tradicionais. Neste aspecto, "As três dimensões fundamentais e vitais do ser humano são: sua individualidade, sua dimensão coletiva e a consciência ecológica” (RODRIGUES, 2003, p.39). Outro aspecto em que a ética deve se fazer presente é com relação ao respeito aos residentes e aos turistas. Os residentes devem manter as suas tradições (costumes e hábitos), evitando construir relações de dependência e de subserviência no contato com os turistas, e o turista, por sua vez, “[...] deve ser tratado com respeito para que se exija também o seu 
respeito" (RODRIGUES, 2003, p.40). O acordo entre as partes tem que ser cumprido, de modo que tanto as comunidades locais quanto os turistas fiquem satisfeitos.

Outra questão que está relacionada ao ecoturismo é a natureza jurídica do empreendimento, podendo esta ser pública ou privada, considerando-se que cada localidade possui uma caracterização. A esse respeito, Rodrigues (2003, p.40) afirma:

Um princípio ético de grande importância é o respeito à propriedade pública e privada. Em grande parte das comunidades da Amazônia, o direito à propriedade não é conceito muito claro para os comunitários. Nas comunidades indígenas em reservas demarcadas ou não demarcadas a terra é coletiva, não se configurando a propriedade privada da terra.

A questão da propriedade pública ou privada estende-se para as demais regiões brasileiras, não ficando restrita apenas à região norte do Brasil. A falta de amparo jurídico pode trazer problemas tanto para as comunidades quanto para os empreendedores, principalmente quando se trata da construção de empreendimentos dentro dos parâmetros legais do país. "Existem empresários inescrupulosos e mesmo responsáveis por ONG’s têm feito acordos com comunidades para a construção de equipamentos ilegais, e o mais grave, com o aval do poder público." (RODRIGUES, 2003, p.41).

No Canadá existe um código de ética que disciplina o planejamento do ecoturismo e procura evitar danos à natureza conservada e também às comunidades tradicionais. No Brasil a constituição de um código como este ainda está em processo de discussão. No entanto, os esforços brasileiros se concentram mais na certificação via selo desenvolvimento sustentável para os empreendimentos que estão em funcionamento e apresentam atuação exemplar. ${ }^{62} \mathrm{O}$ contexto brasileiro revela, portanto, que há a necessidade de se avançar na concepção e na construção de um código de ética para orientar a organização do ecoturismo.

Em virtude de tal quadro em que se encontra o planejamento do ecoturismo no Brasil, parece que as leis deverão ser aplicadas com mais radicalidade aos infratores, no

${ }^{62}$ SALVATI, S. S. (Org.). Turismo responsável - manual para políticas públicas. Brasília: WWF Brasil, 2004. Esta obra traz algumas informações importantes sobre as políticas públicas e as normas legais existentes para a promoção do desenvolvimento do turismo sustentável. Esta obra, para ser publicada, teve o apoio do Centro de Excelência do Turismo da Universidade de Brasília - CET/UnB, do Conselho Brasileiro de Turismo Sustentável - CTBS, do Ministério do Turismo - Mtur e do Ministério do Meio Ambiente - MMA, o que demonstra a articulação entre o poder público e a Organização Não-Governamental WWF. 
intuito de se garantir "o respeito ao patrimônio natural", de forma a evitar que os impactos negativos tornem-se evidentes, descaracterizando o ambiente e as comunidades locais.

Dadas as circunstâncias, os contextos político, econômico, social e cultural em que a sociedade contemporânea se encontra impulsiona e revela a acentuada crise ideológica com relação ao termo desenvolvimento entre os países com menor e maior poder econômico. Então, o caminho é reduzir a pobreza e fortalecer "o acesso das unidades domésticas à base do poder social.” (RODRIGUES, 2003, p.43). Seguindo esta proposição, o desenvolvimento alternativo encontra como opção o ecoturismo, atividade econômica complementar para as comunidades tradicionais. Dessa forma, "As ações devem ser empreendidas no sentido de que na luta a favor das forças locais, no segmento do ecoturismo, seja necessário enfatizar o esforço coletivo, pautando-se pela cidadania responsável.” (RODRIGUES, 2003, p.44).

Furlan (2003, p.47-58), no seu artigo intitulado "Ecoturismo: do sujeito ecológico ao consumidor da natureza", propõe algumas considerações importantes para a compreensão e análise do ecoturismo, que é por esta autora refletido da seguinte forma:

O ecoturismo tem sido considerado como uma modalidade de turismo que poderá criar uma nova prática de lazer associada à conservação da natureza. Alguns autores analisam o ecoturismo como um fenômeno complexo e multidisciplinar, outros o definem como um conceito polissêmico. (FURLAN, 2003, p.47).

Mas sabe-se que as expectativas quanto à expansão do ecoturismo aumentaram, o que pode estar associado às atividades propostas para a sua divulgação desta atividade, permitindo que se construa afinidades e representações simbólicas que perpassam pela ideologia da conservação da natureza e pelo movimento ambientalista em prol de uma nova ética sócio-ambiental.

Nesse sentido, o ecoturismo pode ser compreendido como uma modalidade de turismo voltada para uso de áreas protegidas e de unidades de conservação, incluindo-as nos roteiros turísticos para pequenos grupos de visitantes, já que essas áreas não suportam o turismo de massa. Destaca-se que a análise do ecoturismo no litoral de São Paulo perpassa pelas "ações do governo", dos "setores produtivos" e das "populações locais". O governo do estado de São Paulo aponta o ecoturismo como uma possível alternativa econômica para as comunidades locais que estão localizadas nas áreas protegidas e/ou unidades de conservação. 
"Há direcionamento de investimentos para essas áreas menos urbanizadas, como é o caso do ICMS ecológico, incentivos institucionais promovidos por planos de gestão ambiental das Unidades de Conservação totalmente direcionadas ao ecoturismo etc." (FURLAN, 2003, p.48). Os setores produtivos buscam na natureza conservada as diversas maneiras de torná-la uma mercadoria, tendo no ecoturismo uma forma de comercializá-la, contando com grandes investimentos por parte do poder público e privado.

A inclusão social das populações locais tem sido o discurso utilizado pelos empreendedores turísticos, mas para isto o ecoturismo deve considerar as tradições (hábitos e costumes) das comunidades locais, inexistindo consenso em torno desta problemática. Uma vez percebidos esses fatos básicos, torna-se evidente que "O ecoturismo é um conceito polissêmico $^{63}$ onde o campo de análise econômica e ecológica se aproxima" (FURLAN, 2003, p.49).

No caso específico do Brasil, os movimentos sociais ambientalistas tiveram um papel fundamental na condução das discussões sobre a educação ambiental ${ }^{64}$, iniciando-se na década de 80; daí a relação entre educação ambiental, ecoturismo e a construção do sujeito ecológico. Atualmente, o ecoturismo está sendo apropriado por uma variedade de áreas do conhecimento, entre as quais a economia. Desse modo, "Podemos dizer que o ecoturismo se transformou em mais uma das respostas do setor produtivo às pressões sociais pela conservação ambiental" (FURLAN, 2003, p.50). A construção do sujeito ecológico também passou por mudanças bruscas, desde a perda de radicalidade até a sua cooptação pelo setor produtivo. Daí o surgimento de vários tipos de ecoturistas, entre eles o ecoturista como um sujeito romântico e/ou racionalista, o ecoturismo militante, o ecoturista alienado e o ecoturista articulado com o setor produtivo.

No decorrer das duas últimas décadas do século XX, aconteceram transformações no contexto econômico, implicando novas condições de existência para o sujeito (ideológico e real). Com a globalização, a ciência e a tecnologia assumiram um status quo nunca alcançado anteriormente; assim, no âmago do problema encontra-se a sociedade contemporânea. Hoje,

\footnotetext{
${ }^{63}$ Vem da palavra polissemia, indicando "qualidade de uma única palavra ter diferentes significações, conforme o contexto em que ocorre. F. gr. Polys (muito) + sema (sinal. significação) + ia. Cf. A.. Nascentes. Dic. Etmológic" (AULETE, 1970, vol.IV, p.2872).

${ }^{64}$ A obra de DIAS (2000), com o sugestivo título "Educação Ambiental; princípios e práticas", contribui para a análise, a compreensão e a identificação do quadro em que se encontra o debate teórico e metodológico sobre a educação ambiental no Brasil e no Exterior.
} 
"Do ponto de vista estritamente econômico o sujeito real, com suas múltiplas identidades, é identificado como o cliente do ecoturismo. Para conquistar esse cliente é fundamental seduzílo. Ou seja, é preciso lidar com suas utopias, envolver-se nas suas expectativas" (FURLAN, 2003, p.52).

O processo de sedução do sujeito real tem sido marcante nos programas de ecoturismo, na sua forma de divulgação da natureza conservada como uma mercadoria a ser comercializada com o intuito de satisfazer as necessidades dos clientes por meio da construção e da reconstrução das identidades dos lugares. Por isso, até as modalidades de turismo tornaram-se dinâmicas, isto é, estão sempre sendo criadas e recriadas para atender a oferta e a procura de um mercado globalizado.

O fator humano envolvido com o ecoturismo carece de uma estratégia crítica, a qual pode ser encontrada na ação educativa e de entendimento. A educação deve influenciar na adoção de novas concepções de mundo, as quais estão articuladas com o entendimento do mundo; daí surgirão ações críticas que irão de encontro com as transformações que são necessárias neste mundo globalizado. $\mathrm{O}$ equilíbrio ecológico poderá ser atingido, mas nas seguintes condições:

Como ação educativa à vivência com a natureza, pode se constituir desvelamento, sensibilizando o sujeito, propondo através do exercício de observação a reflexão que pode levar a compreensão dos lugares. Ação estratégica e educativa se combinam para a formação do sujeito ecológico, aquele cuja utopia transformadora do mundo possa mudar sociedades inteiras em sua trajetória histórica. (FURLAN, 2003, p.53).

De acordo com o pensamento da autora, a ação estratégica e educativa pode ser uma forma de evitar as contradições impostas pelo setor produtivo de caráter eminentemente econômico. Este, por intermédio das práticas oportunistas de turismo disfarçado de ecoturismo, pode garantir as condições necessárias para a produção e reprodução do capital, porém mantendo as comunidades locais nas mesmas e/ou em piores situações econômicas, sociais, culturais e ambientais. Como evitar que tais práticas ocorram? Na lógica do conjunto dos referidos setores, deve-se evitar o acontecimento da sobreposição e da subserviência de um setor em relação ao outro, de modo que as associações indígenas podem ser consideradas 
fundamentais no equilíbrio de poder entre os setores que compõem a prática do ecoturismo em territórios indígenas. ${ }^{65}$

As reflexões sobre ecoturismo e sustentabilidade têm apontado para a conservação da natureza e o fortalecimento das populações locais e dos direitos humanos. O bem-estar social passou a ser reivindicado em todos os lugares do mundo; por isso o conjunto dos setores responsáveis pelo turismo deverá atuar na busca de soluções concretas para os impasses existentes. Nesse sentido, vale enfatizar a origem do termo sustentabilidade:

O termo sustentabilidade surgiu no ano de 1713, quando Carlowitz utilizou-o para se referir à exploração de florestas cultivadas na Alemanha. Seu significado para a época era restrito a qualquer prática de utilização do solo que garantisse em longo prazo rendimentos econômicos estáveis. (FURLAN, 2003, p.54).

\section{Com a realização do Fórum das Nações Unidas Sobre Meio Ambiente e} Desenvolvimento/ Agenda 21 (1992), o termo sustentabilidade adquiriu popularidade, passando a ser usado em diversas circunstâncias, até mesmo naquelas em que seu conceito se faz pouco propício. O uso do termo sustentabilidade pode, assim, cair na banalidade, pois assimilar o mencionado termo não implica na adoção da prática da conservação da natureza e no respeito às comunidades locais. Daí o surgimento de novos termos, como, por exemplo, “crescimento sustentável”, “uso sustentável” e "desenvolvimento sustentável”, cada um tendo o seu significado.

Nesse sentido, "Qualidade se constrói e se desenvolve numa cultura. É algo inteligível de uma cultura. Não tem existência exterior. Existe numa relação, surge de uma observação e de um observado" (FURLAN, 2003, p.55). A cultura pode ser considerada dinâmica, mais é essencial mantê-la para se evitar danos sociais, políticos, culturais, econômicos e ambientais. Para isto, faz-se necessário compreender o dinamismo cultural numa perspectiva crítica e de ruptura quando indicada a ocasião. De uma parte, há a ineficácia das políticas públicas para os planos de conservação ambiental, do turismo e do ecoturismo, tratando-os de maneira semelhante, o que implica em estranhamento entre os setores envolvidos. De outra, deve-se priorizar a eficiência das políticas públicas para o atendimento do planejamento ambiental para todos os setores. Nesse aspecto, "Os nossos objetos turísticos têm significados socioculturais complexos, lidam com idéias e utopias, exigem a

\footnotetext{
${ }^{65}$ Conforme a proposição de Rodrigues (2003, p.32-44).
} 
especialização profissional, possuem uma sazonalidade intrínseca, enfim...” (FURLAN, 2003, p.57).

O território indígena Krahô possui natureza conservada e comunidades locais, e pode ser considerado pela legislação como área protegida, apresentando-se como uma referência para a análise do ecoturismo. Neste contexto, a população indígena Krahô se encontra dividida em dezoito (18) aldeias, as quais estão associadas à KÁPEY - União das Aldeias Krahô. São elas: Pedra Branca, Pedra Furada, Manoel Alves Pequeno, Cachoeira, Rio Vermelho, Santa Cruz, Forno Velho, Morro do Boi, Água Branca, Riozinho, Lagoinha, Campos Lindo, Macaúba, Serra Grande, Bacuri, Aldeia Nova, Galheiro e São Vidal. A seguir, pode-se observar a população correspondente a cada uma dessas aldeias:

Tabela 03 - Relação das Aldeias Krahô e população

\begin{tabular}{|l|c|}
\hline \multicolumn{1}{|c|}{ Aldeia } & População \\
\hline 01. Pedra Branca & 304 \\
\hline 02. Pedra Furada & 80 \\
\hline 03. Manoel Alves Pequeno & 179 \\
\hline 04. Cachoeira & 286 \\
\hline 05. Rio Vermelho & 263 \\
\hline 06. Santa Cruz & 283 \\
\hline 07. Forno Velho & 90 \\
\hline 08. Morro do Boi & 89 \\
\hline 09. Água Branca & 48 \\
\hline 10. Riozinho & 50 \\
\hline 11. Lagoinha & 50 \\
\hline 12. Campos Lindo & 79 \\
\hline 13. Macaúba & 23 \\
\hline 14. Serra Grande & 76 \\
\hline 15. Bacuri & 74 \\
\hline 16. Aldeia Nova & 93 \\
\hline 17. Galheiro & 80 \\
\hline 18. São Vidal & 30 \\
\hline Total da População Indígena & 2.129 \\
\hline Fone: Pesqusa Canpo, 2004 & \\
\hline
\end{tabular}

Fonte: Pesquisa de Campo, 2004. 
Os índios Krahô distribuídos nas dezoito (18) comunidades indígenas se comunicam pelo rádio amador. No ano de 2005 foi inaugurada a Rádio Comunitária HATÃ, que tem contribuído para aumentar a comunicação entre os Krahô. O programa da Rádio é realizado na Língua Timbira, Dialeto Krahô, de modo que a tradição da oralidade entre os Krahô possui um novo componente da modernidade para acentuar as relações interétnicas e interculturais.

Do ponto de vista dos Krahô, o PDISK pode ser considerado um projeto relevante para o turismo, o que revela que as ações da Kapey foram fundamentais para o início da organização do turismo no território indígena Krahô. Destarte, pode-se considerar que o turismo no referido território apenas está passando por um processo de modernização, tendo maior recepção de turistas durante os eventos culturais realizados na Kapey. Contudo, as comunidades nativas organizadas em associações indígenas estão conseguindo aprovar projetos inovadores, assim como colocá-los em prática.

A estrutura política das aldeias constitui-se da seguinte maneira: $P A A H I$ (Cacique), HÕMRẼ (Prefeito) e MẼ CUMÃ HAPAC KRE CATÊ (Conselheiro). Estes representam as lideranças mais fortes das aldeias, sendo autoridades respeitadas pela comunidade.

Cada aldeia tem o seu Ká (Pátio) em forma de Pyt (Sol), contando com um caminho que liga o seu centro a cada casa da povoação. O Pátio tem um significado importante para os povos indígenas Krahô: representa o alto do mundo, o lugar de resolver conflitos, de firmar acordos e de manter a união. Seu tamanho varia de acordo com a quantidade de casas da povoação; as aldeias mais populosas têm o Pátio maior e as menos populosas têm o Pátio menor. É neste local que se realizam as reuniões e os rituais e que são recebidos os visitantes: os $M \tilde{E} H \tilde{I}$ (índios) de outras aldeias e etnias e os $C U P \tilde{E}$ (povos não-indígenas) brasileiros e estrangeiros.

O PAAHI (Cacique), o HÕMRẼM (Prefeito) e o MẼ CUMÃ HAPAC KRE CATÊ (Conselheiro) recebem os visitantes primeiro no Ká (Pátio), onde os apresentam à comunidade da aldeia. Essa é a forma de proteger a MẼHCUNA (comunidade) e o PJÊ (território) indígena da presença de pessoas desconhecidas. 
Existem dois grupos distintos na organização social dos povos indígenas Krahô: o primeiro constituído pela família residencial - o marido, a mulher e os filhos ${ }^{66}$; e o segundo formado por sogro, sogra, filhas, genros, netos e netas ${ }^{67}$. As metades sazonais, por sua vez, se dividem de acordo com as estações: a estação seca (ao dia, ao leste, ao pátio central) e a estação chuvosa (à noite, ao oeste, à periferia). As reuniões acontecem no pátio e contam com a presença das duas metades sazonais e dos dois "prefeitos", mas as decisões são tomadas pela metade que se encontra em exercício (no poder); a outra metade obedece. Cada metade recebe um nome específico para se identificar com o grupo ${ }^{68}$; as mulheres solteiras pertencem à metade do pai e as casadas à metade do marido. ${ }^{69}$

A Kapey tem a forma das aldeias. Todas as aldeias são responsáveis pela manutenção, reforma, limpeza e administração do patrimônio dos povos indígenas Krahô.

${ }^{66}$ Este grupo é mais comum nos povos indígenas Krahô; na língua Krahô é denominado de Família Residencial (IH KRÃRĨ IKRE JÕ PAHI MÃ APREQUÊT); o marido, a mulher e os filhos podem construir uma família menos numerosa, com menos pessoas numa mesma casa. Com o nascimento do primeiro filho forma a família, permitindo a separação da casa e da roça. A roça às vezes continua junto à roça do sogro e da sogra (Pesquisa de campo, 2004, 2005 e 2006).

${ }^{67}$ Atualmente, está cada vez mais difícil mantê-lo; apenas os mais velhos mantém esse costume, enquanto que os mais jovens estão estudando e procurando permanecer mais no primeiro grupo. $\mathrm{O}$ primeiro neto é como um filho, os avós cuidam dele e o tratam bem. Mas, pode-se registrar a existência da estrutura familiar tendo o sogro e a sogra como os donos da casa, na língua Krahô é chamado de Família Geral (IKRE KÃM MẼHCUNÃ). Além dos Prefeitos, dos Caciques e dos Conselheiros, o sogro como chefe de uma família geral pode ser considerado autoridade na comunidade indígena da aldeia (Pesquisa de campo, 2004, 2005 e 2006).

${ }^{68}$ Por exemplo: Txyhcapro Txêpỳm Inxũm Crà Parkãmpen Mumico, esses nomes em MEHĨ pertencem apenas a um Índio Krahô, o define como membro da metade sazonal da estação seca (ao dia, a leste), nas reuniões no Cà (Pátio) permanece na posição Leste. Os povos indígenas Krahô que pertencem à estação seca estarão na posição Leste. Ao nascer a criança recebe os nomes dos parentes, na véspera do nascimento os parentes procuram ficar mais próximos da casa para dar os nomes, do lado do pai ou da mãe, esses nomes implicam na participação política na comunidade indígena. De manhã bem cedo, quando a criança nasce o Cantador ou Conselheiro visita a casa dos pais da criança e depois desloca até o KÁ (Pátio) e começa a cantar uma música para as pessoas que não visitaram a criança. Toda a comunidade da aldeia vai saber do nascimento da criança e pela música vai saber que partido vai pertencer (Chuva/Katameye ou Seca/Wakmye). A maioria das mulheres da comunidade visita à criança e fica sabendo do nome. As duas metades ficam atentas aos nascimentos das crianças para manter um número equilibrado nas duas metades, mas sempre uma metade é maior que a outra. A metade representada pela estação da chuva/ Katameye tem um número maior de povos indígenas; porém a diferença entre as duas metades, uma com maior número de povos indígenas, a outra com menos não implica na organização política, as duas metades continuam representando os partidos. Enfim, existe a preocupação em manter o equilíbrio entre as duas metades, ou seja, uma diferença menos acentuada. (Pesquisa de campo, 2004, 2005 e 2006).

${ }^{69}$ LÉVIS-STRAUSS (1982), em sua obra intitulada "As estruturas elementares do parentesco", traz um aprofundado estudo sobre os sistemas de parentesco, conteúdo importante para se compreender a estrutura da organização familiar (cônjuges possíveis e cônjuges impossíveis) das populações autóctones. 
Quando há um evento importante todas as aldeias mobilizam esforços para cuidar das reformas. Os Caciques, os Prefeitos e os Conselheiros fazem reuniões nas aldeias e definem quais índios irão contribuir para as reformas. Todos os índios têm orgulho de fazer os trabalhos que deixam a KAPEY mais bonita (como, por exemplo, fazer a coleta do lixo, atividade que foi registrada e é apresentada na figura a seguir) para receber os turistas indígenas e não-indígenas. Cabe ressaltar que a maioria dos turistas é de povos indígenas e o restante de povos não-indígenas (estudantes universitários e funcionários públicos no âmbito do governo federal ligado aos povos indígenas).

Figura 09 - Coleta do Lixo na Kapey

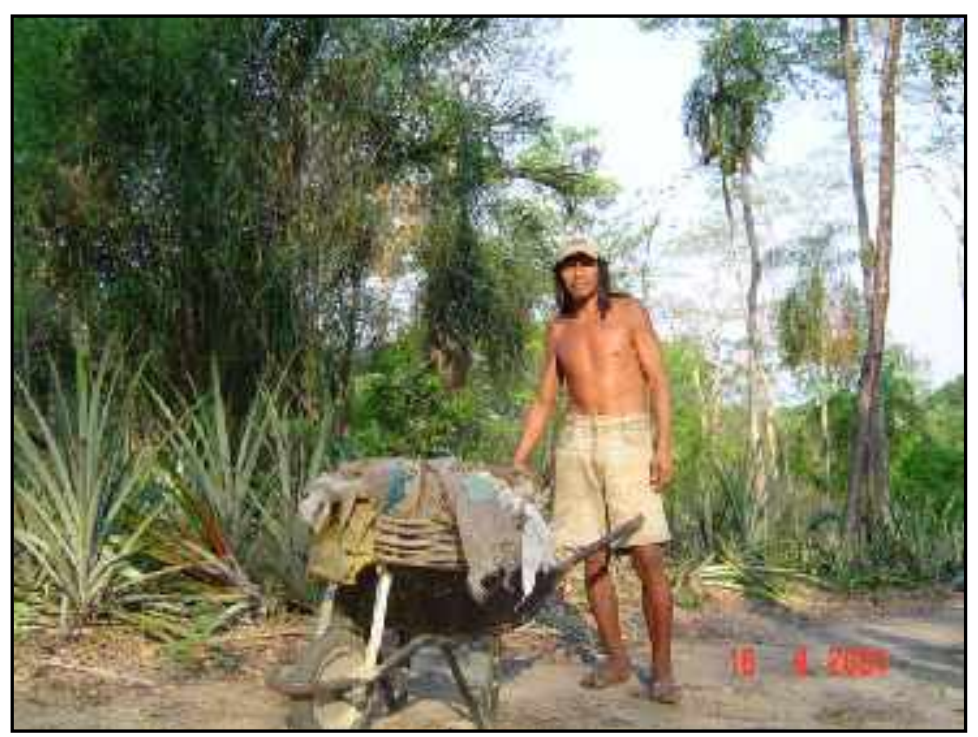

Fonte: Autor, 2004.

Os eventos mais esperados no ano de 2004 foram: a inauguração do PDISK - Projeto de Desenvolvimento Integrado Social Krahô, que aconteceu no dia 19 de abril; e a VI Feira Krahô de Sementes Tradicionais, realizada no período de 23 a 25 de setembro. As comunidades das dezoito (18) aldeias Krahô e de outras populações de etnias diversas participaram dos referidos eventos organizados pela KAPEY para efetuarem a troca de variedades de sementes tradicionais. Cada índio trouxe de sua roça sementes tradicionais para trocar por outras sementes tradicionais, mantendo variedades de sementes na agricultura tradicional. 
Os Pátios das aldeias e o Pátio da KAPEY constituem espaços de manifestação da cultura Krahô. Os rituais que acontecem durante o ano ocorrem nos Pátios, sendo que cada aldeia organiza os seus cerimoniais seguindo o calendário de rituais Krahô. Vale ressaltar que cada ritual tem uma duração, um significado específico e uma ordem de importância. As corridas de tora, as corridas da flecha e os desfiles rituais ocorrem em sentido anti-horário, conforme demonstra a figura apresentada a seguir.

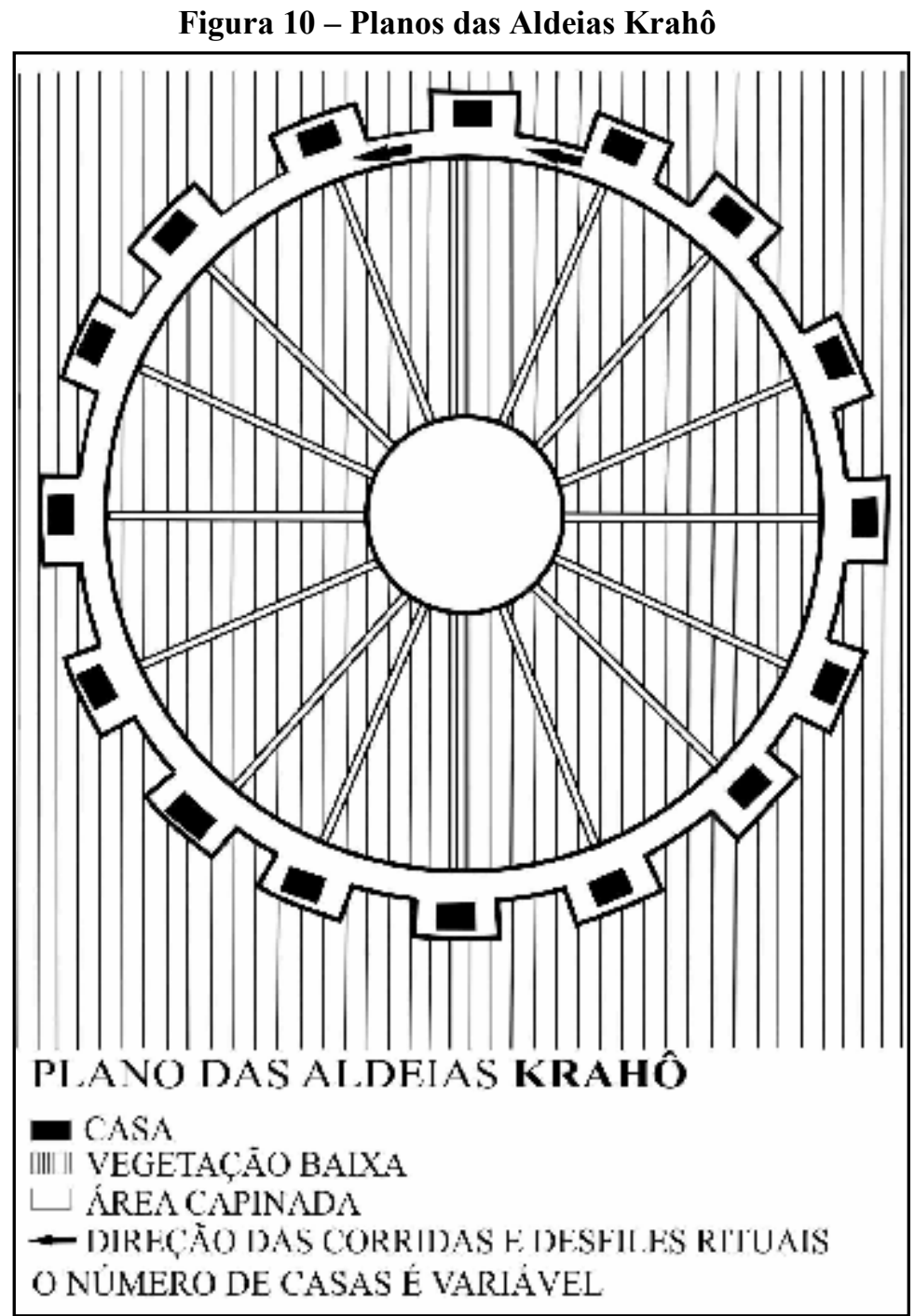

Fonte: Melatti, 1978, p.33. 
Esta é uma forma de manifestação cultural milenar que marca uma época em que os indígenas tinham pouco ou nenhum contato com os povos não-indígenas.

Cada aldeia possui os cantadores e as cantadoras; os homens são os puxadores das cantorias e as mulheres os acompanham. O instrumento musical mais utilizado é o Cuhtoj ${ }^{70}$ (maracá), uma espécie de chocalho que produz um som, imitando talvez a cascavel, quando percutido; também são muito utilizados alguns instrumentos de sopro. Todos os instrumentos musicais são produzidos pelos próprios povos indígenas, que, para tanto, utilizam materiais encontrados no território indígena Krahô. De certa maneira, vários são os preparativos para a realização dos rituais, desde a preparação de alimentos para serem consumidos durante os rituais até as pinturas corporais e as escolhas das canções.

A seguir, pode-se observar algumas cenas demonstrando os preparativos para os rituais.

Figura 11 - Grupos de Rituais Krahô

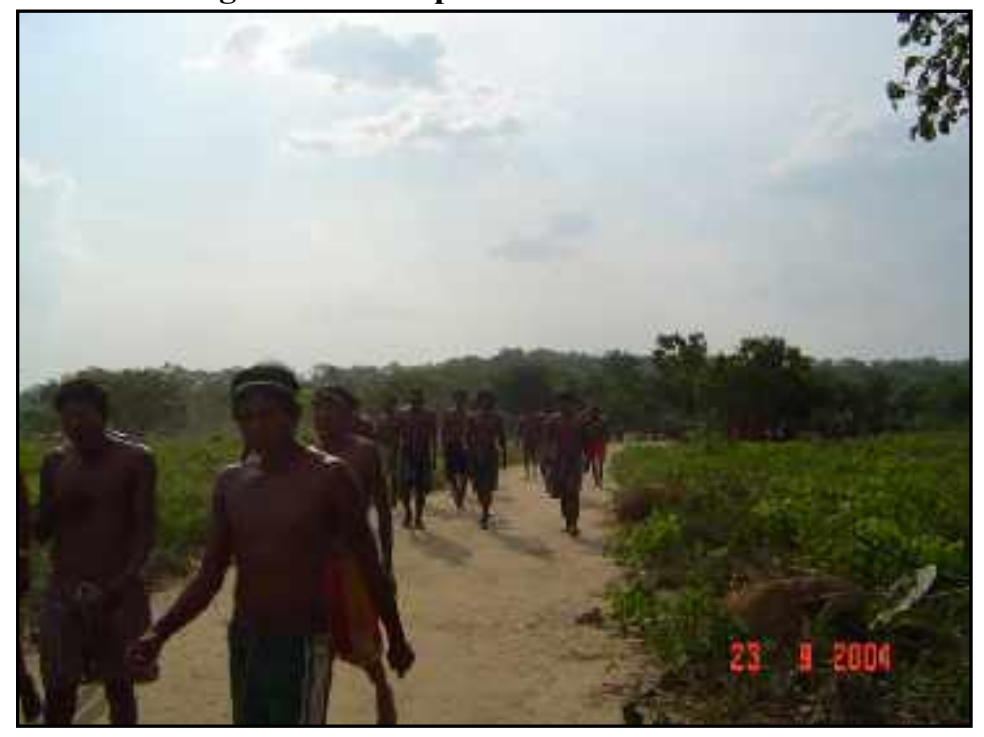

Fonte: Autor, 2004.

\footnotetext{
${ }^{70}$ Pode ser considerado o instrumento musical mais utilizado entre os cantadores Krahô. "Este maracá é feito pelos homens e só eles o usam para cantar. É feito do fruto da árvore que dá cuité. Ela é uma arvore bem grande e quando dá frutos eles são bem grandes. As mulheres usam o cuité para fazer cuia. Elas tiram o fruto da árvore, partem ao meio. A cuia serve par pôr comida. Para fazer o cuité é preciso pôr o fruto de molho durante duas semanas; depois, tira a água, fura dos lados e derrama a água e as sementes que estão dentro. O buraquinho vai servir par pôr o cabo do maracá. Em seguida, coloca-se o cuité ao sol para secar, bastando um dia para isso. Depois de seco, já se pode pôr o cabo no cuité. O cabo é feito de madeira pau-brasil, mais antes disso é preciso colocar sementes de outra fruta dentro. Aí, já está pronto para fixar o cabo. Para terminar, pinta-se com urucum todo o cuité que está bom para se usar quando se canta e dança nas festas." (KRAHÔ, 1997, p.37).
} 
Figura 12 - Cantorias no Pátio

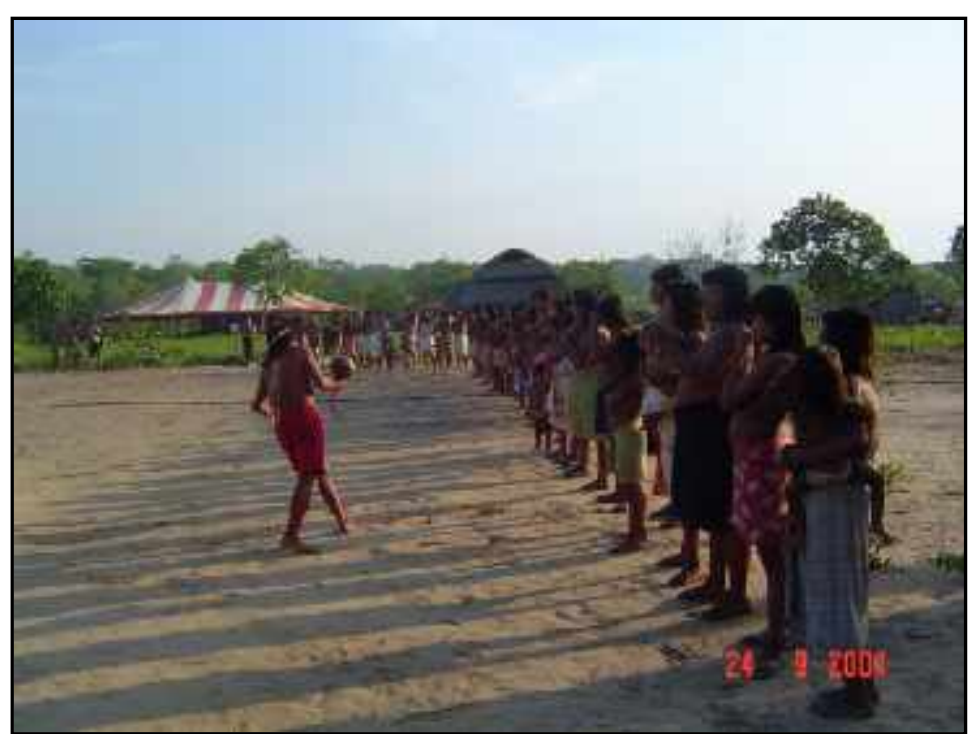

Fonte: Autor, 2004.

Figura 13 - Posição Lado Leste do Pátio

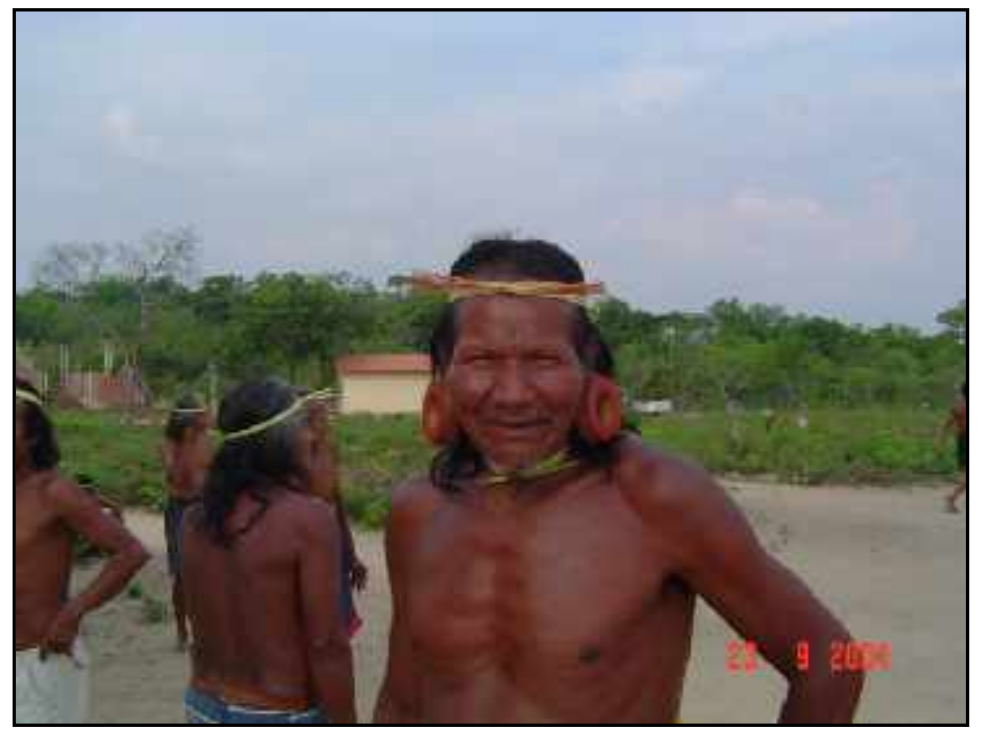

Fonte: Autor, 2005. 


\subsection{FEIRAS KRAHÔ DE SEMENTES, TURISTAS E ACAMPAMENTO}

A Feira Krahô de Sementes Tradicionais foi organizada pela primeira vez em 1997; as feiras subseqüentes aconteceram em 1998, 1999, 2001, 2002 e 2004, conforme demonstra a tabela apresentada a seguir:

Tabela 04 - Feiras de Sementes realizadas no território indígena Krahô

\begin{tabular}{|l|l|}
\hline \multicolumn{1}{|c|}{ Eventos } & Ano \\
\hline I Feira Krahô de Sementes Tradicionais & 1997 \\
\hline II Feira Krahô de Sementes Tradicionais & 1998 \\
\hline III Feira Krahô de Sementes Tradicionais & 1999 \\
\hline IV Feira Krahô de Sementes Tradicionais & 2001 \\
\hline V Feira Krahô de Sementes Tradicionais & 2002 \\
\hline VI Feira Krahô de Sementes Tradicionais & 2004 \\
\hline
\end{tabular}

Fonte: Pesquisa de Campo, 2004, 2005 e 2006.

Nota-se, assim, que do primeiro até o terceiro evento manteve-se um intervalo de um ano para a realização da Feira Krahô de Sementes Tradicionais. A partir da quarta Feira esse intervalo de tempo aumentou para dois anos. Em 2004, ano em que foi realizado o VI Evento, esta Feira Krahô contou com a participação dos povos indígenas Krahô, dos povos indígenas de outras etnias e também dos povos não-indígenas. Esta edição da Feira aconteceu entre os dias 23, 24 e 25 de setembro de 2004 e envolveu a colaboração da Kapey, da FUNAI, da FUNASA, do MMA (mais especificamente da Coordenadoria de Agroextrativismo), do MDS, da Secretaria de Segurança Alimentar e Nutricional, da Embrapa, do Programa Biodiversidade Brasil/ Itália, do Governo do Estado do Tocantins e da Prefeitura Municipal de Itacajá.

As Feiras Krahô de Sementes Tradicionais valorizam a agricultura da população indígena Krahô e, por conseguinte, reforçam a identidade étnica e a auto-estima desta população, além de promover a divulgação da cultura dos Krahô para outros povos indígenas e não-indígenas. A venda do artesanato para os turistas, as pinturas corporais indígenas, os rituais, as comidas típicas, as cantorias no pátio, as manifestações culturais e os diálogos entre 
participantes indígenas e não-indígenas durante a realização das Feiras também contribuem para a valorização cultural dos Krahô.

Pode-se afirmar, ainda, que a Feira Krahô de Sementes Tradicionais, cujo número de participantes indígenas tem aumentado a cada edição, é o evento mais esperado pelos povos indígenas brasileiros. Entretanto, devido a dificuldades de recursos financeiros, passou a ser realizada de dois em dois anos, podendo passar a acontecer de três em três anos, conforme proposta discutida na reunião ${ }^{71}$ que aconteceu após o término da VI Feira Krahô de Sementes Tradicionais.

A organização da primeira edição desse evento teve o intuito de melhorar a agricultura tradicional Krahô. Os resultados que alcançou podem ser considerados positivos, pois a variedade de produtos agrícolas cultivados aumentou, assim como a produção de alimentos. Durante o referido evento, a população Krahô e os povos indígenas de outras etnias efetuaram trocas de sementes tradicionais retiradas de suas roças, permitindo a manutenção de várias espécies de plantas nos seus cultivos.

As Feiras Krahô de Sementes Tradicionais, como já foi mencionado, podem ser consideradas eventos turísticos, uma vez que contam com a participação, além de populações indígenas de várias etnias, de povos não-indígenas. Estes últimos, portanto, podem ser entendidos como turistas, sendo representados pelos estudantes universitários ${ }^{72}$, pelos funcionários públicos no âmbito do governo federal ${ }^{73}$ e pelos representantes de Organizações Não-Governamentais ${ }^{74}$ que trabalham diretamente com as comunidades indígenas.

\footnotetext{
71 "Conforme informações coletadas na pesquisa de trabalho de campo no mês de setembro de 2004, a participação nas reuniões da Kapey envolvendo os dezoito (18) caciques das aldeias, os índios que estão coordenando os projetos do PDPI, indigenistas da Funai, pesquisadores da Embrapa-Cerrados e técnicos do PDPI possibilitou compreender questões relacionadas ao desenvolvimento dos projetos." (Pesquisa de campo, 2004, 2005 e 2006).

72 "Estes são provenientes de várias universidades, entre elas: Universidade de São Paulo (USP), Universidade Federal do Rio de Janeiro (UFRJ), Universidade Estadual do Rio de Janeiro (UERJ), Universidade Federal de Uberlândia (UFU), Universidade de Brasília (UNB), Universidade Federal do Tocantins (UFT), Universidade Católica de Goiás (UCG) e Universidade Federal de Goiás (UFG)." (Pesquisa de campo, setembro de 2004).

73 Banco Nacional do Desenvolvimento Econômico e Social (BNDES), Ministério do Meio Ambiente/Coordenadoria de Agroextrativismo, Ministério do Desenvolvimento Social e Combate a fome/Secretaria de Segurança Alimentar e Nutricional, Ministério da Cultura, Ministério da Agricultura/ Embrapa e Fundação Nacional do Índio.

${ }^{74}$ Programa Biodiversidade Brasil/Itália.
} 
Os turistas ficam alojados na área de camping em barracas, e cada grupo de visitantes prepara a sua própria alimentação. Nas figuras apresentadas a seguir, pode-se verificar a área em que os turistas ficam alojados.

Figura 14 - Acampamento Kapey

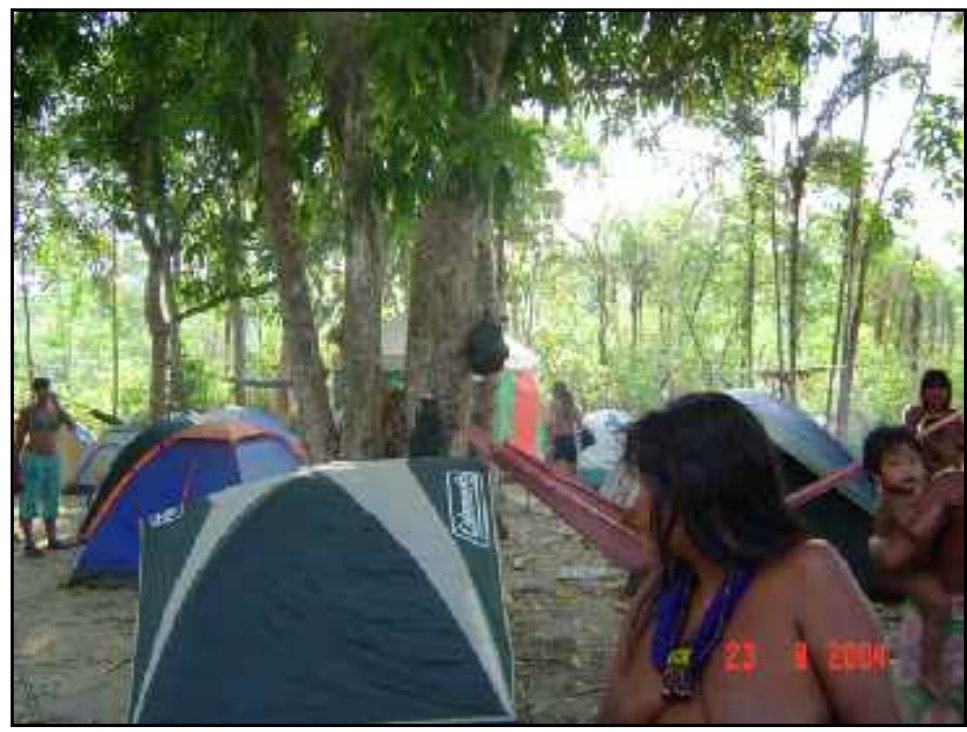

Fonte: Autor, 2004.

Figura 15 - Acampamento Kapey

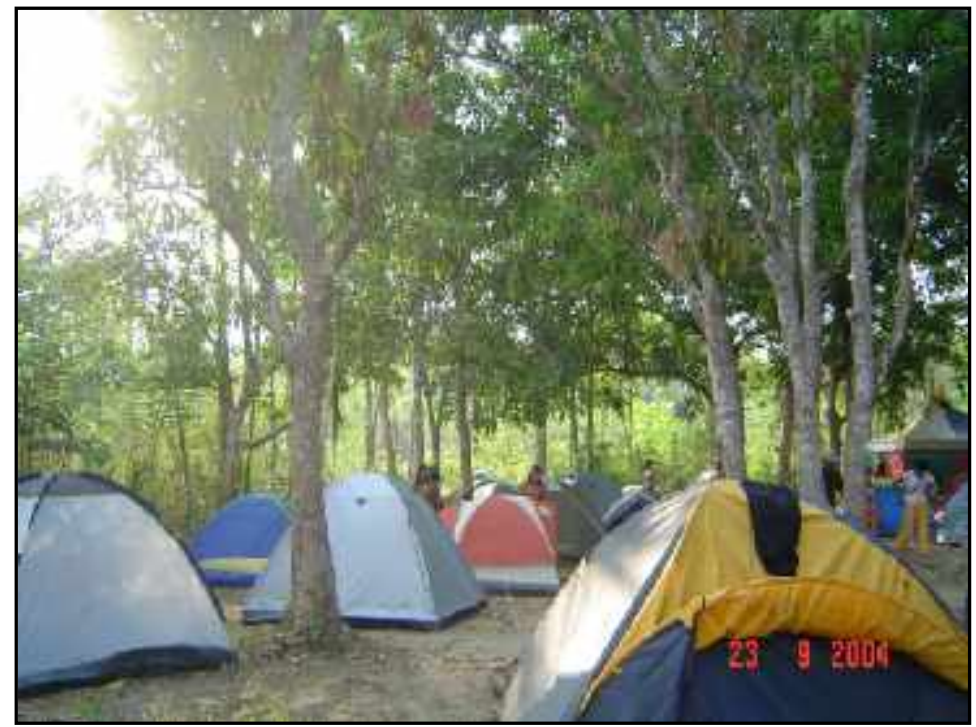

Fonte: Autor, 2004. 
Como parte da programação da VI Feira Krahô de Sementes Tradicionais, ocorreu a preparação de alimentos típicos da alimentação Krahô, entre os quais: Paparuto de Milho Verde com Banana, Paparuto de Mandioca com Carne Bovina, Paparuto de Mandioca com Peixe e Peixe Assado. Entre os sucos naturais feitos com as frutas típicas do cerrado e oferecidos aos visitantes se destacaram: Bacaba, Buriti, Açaí, Caju, Cajá, Murici e Batatadoce, entre outros. A seguir, pode-se observar este momento que fez parte do evento.

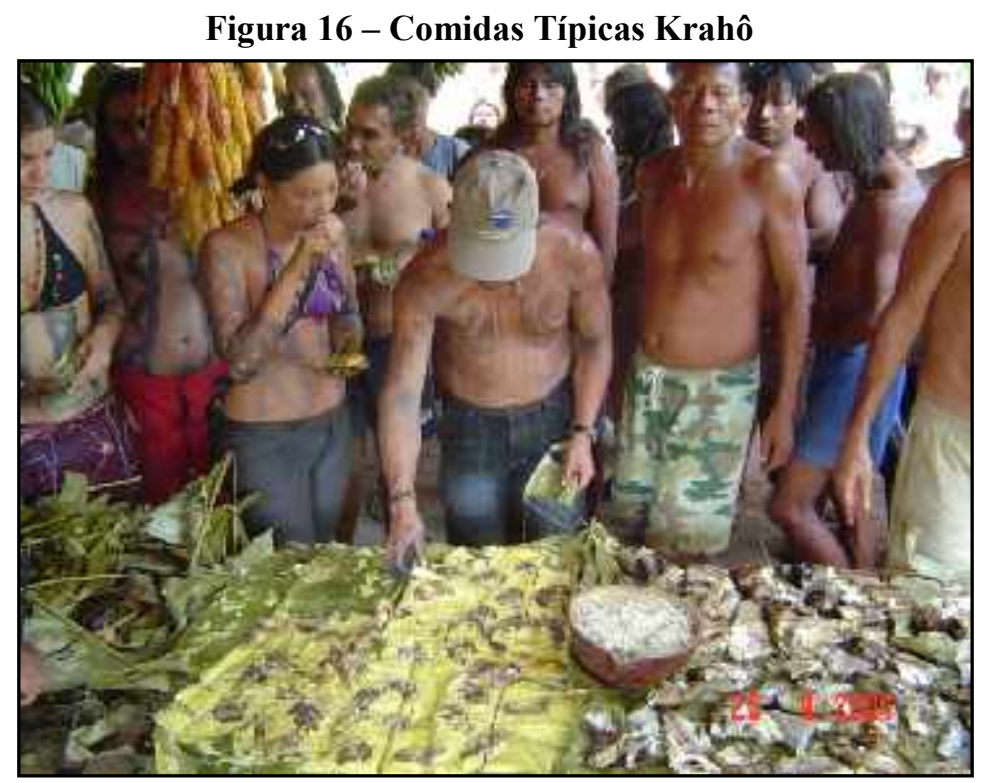

Fonte: Autor, 2004.

As Feiras Krahô de Sementes Tradicionais atraem turistas motivados por diversos fatores. Há aqueles que possuem afinidades com as populações indígenas, aqueles que estão desenvolvendo estudos de graduação ou de pós-graduação, aqueles que realizam pesquisa não-acadêmica, os ecologistas, os hippes e os interessados pela compra de artesanatos, entre outros. Os estudantes desenvolvem pesquisas e fazem o registro do evento, observando-o e analisando-o para avançar na estruturação de novos projetos, aprimorar os resultados práticos e, por último, continuar com a proposta de promover a Feira Krahô de Sementes Tradicionais.

Essas Feiras representam para a população indígena Krahô uma saída da crise econômica e social que foram enfrentadas nas décadas de 1960, 1970, 1980 e 1990. Permitiram, ainda, que os Krahô tivessem uma projeção nacional e internacional na última década do século XX. 
A seguir, pode-se observar algumas imagens captadas durante a realização da VI Feira Krahô de Sementes Tradicionais.

Figura 17 - Troca de Sementes Entre as Etnias

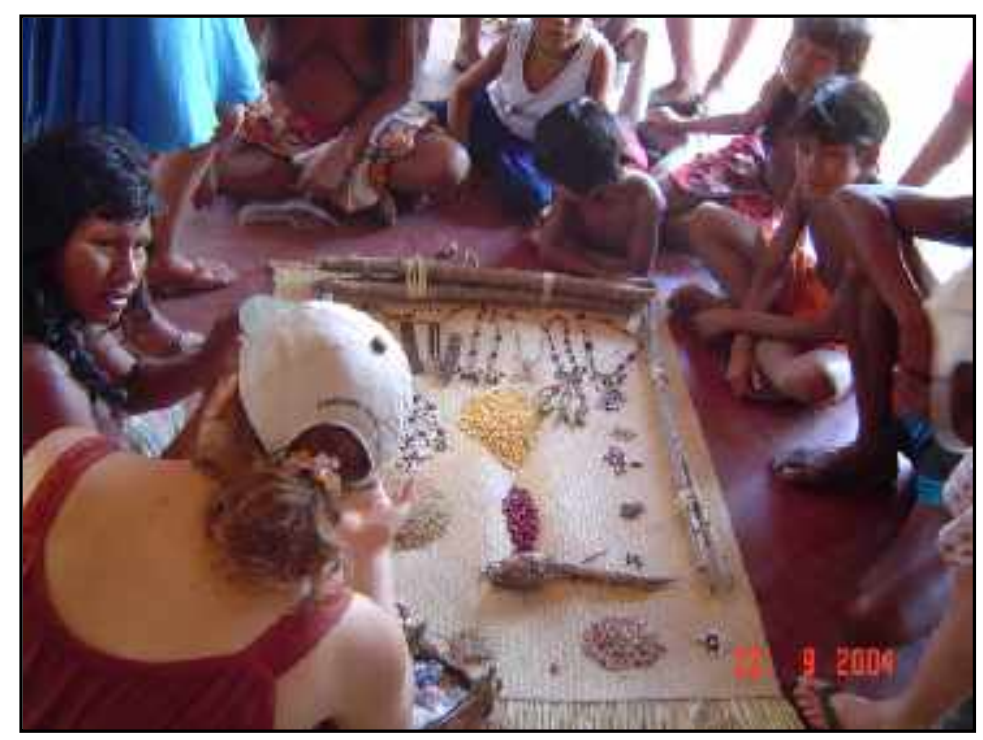

Fonte: Autor, 2004.

Figura 18 - Exposição de Sementes Tradicionais

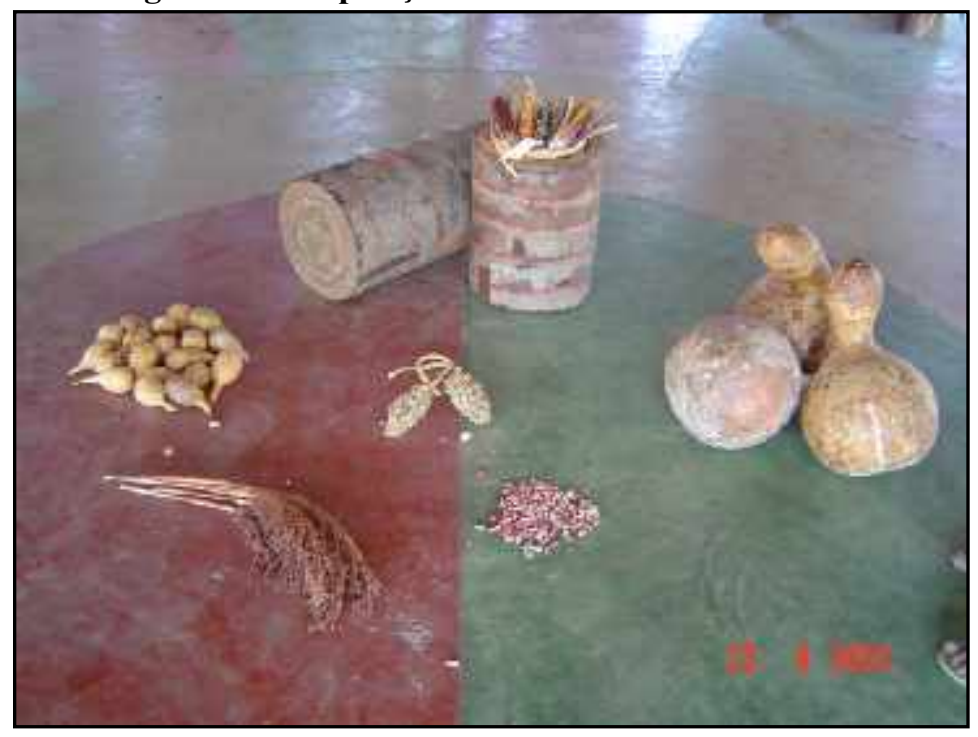

Fonte: Autor, 2004. 
Figura 19 - Exposição de Sementes Tradicionais

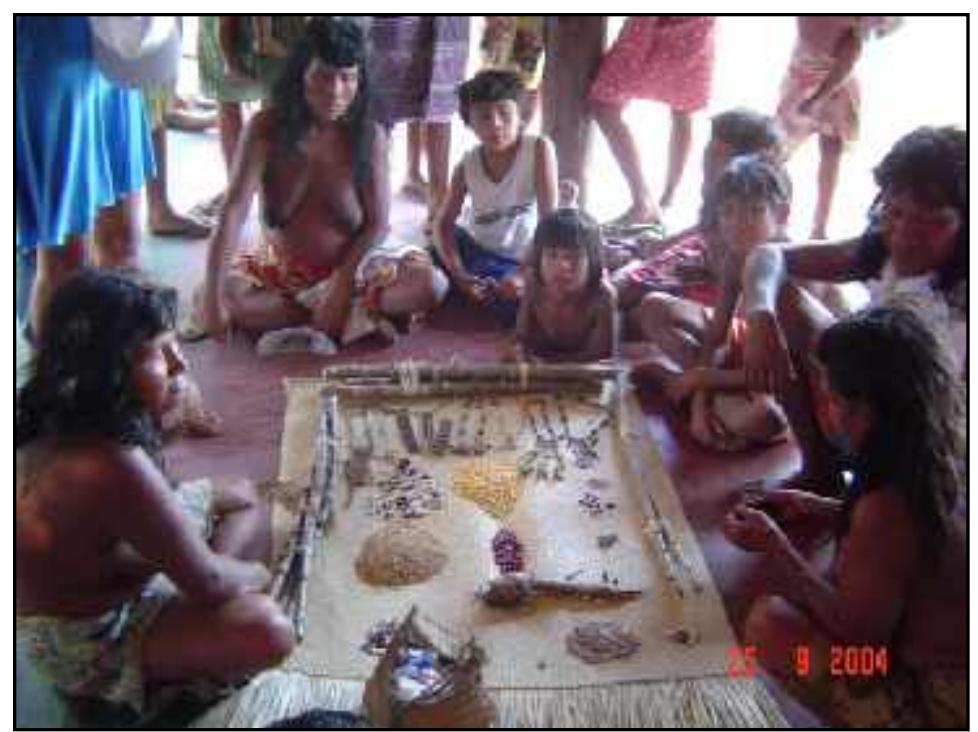

Fonte: Autor, 2004.

Figura 20 - Exposição de Sementes - Embrapa - na VI Feira Krahô

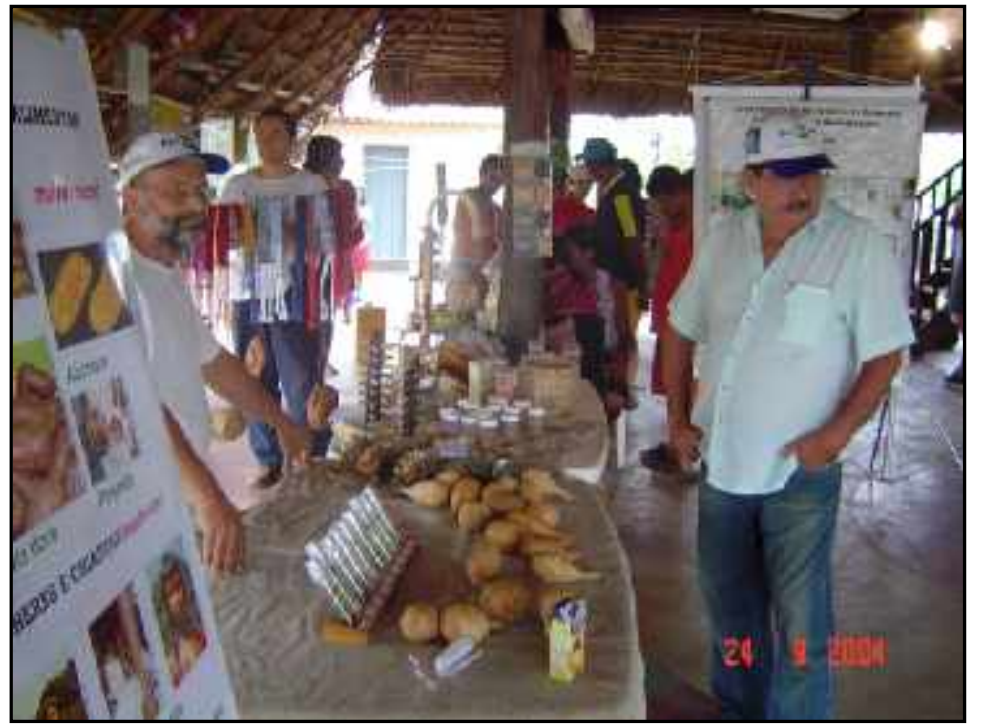

Fonte: Autor, 2004. 


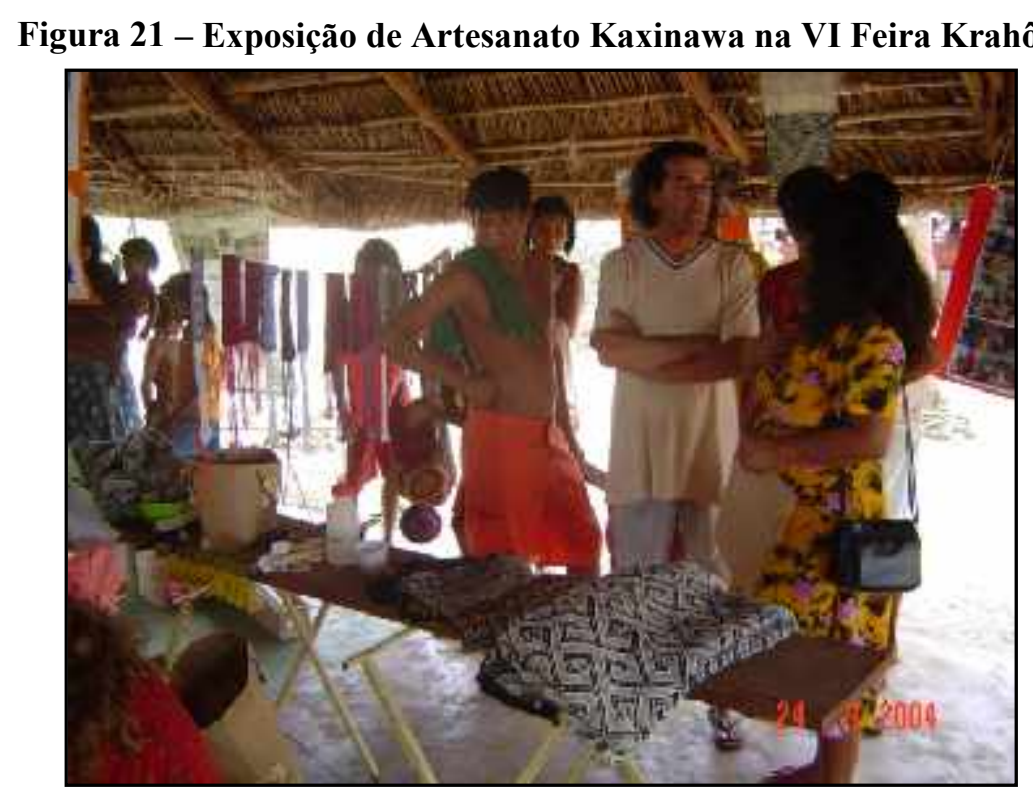

Fonte: Autor, 2004.

As manifestações culturais promovidas na VI Feira Krahô de Sementes Tradicionais incluíram cantigas, danças, rituais e apresentações teatrais dos Hotxa (atores) Krahô. Durante a apresentação teatral, o Secundo Krahô, considerado cantador e puxador de cantorias, narrou uma história Krahô e os atores o acompanharam fazendo performances corporais. Dessa forma, parte da cultura Krahô foi apresentada para as outras populações indígenas e nãoindígenas, como se pode notar na figura apresentada a seguir: 
Figura 22 - Apresentação dos Hotxa (Atores) Krahô

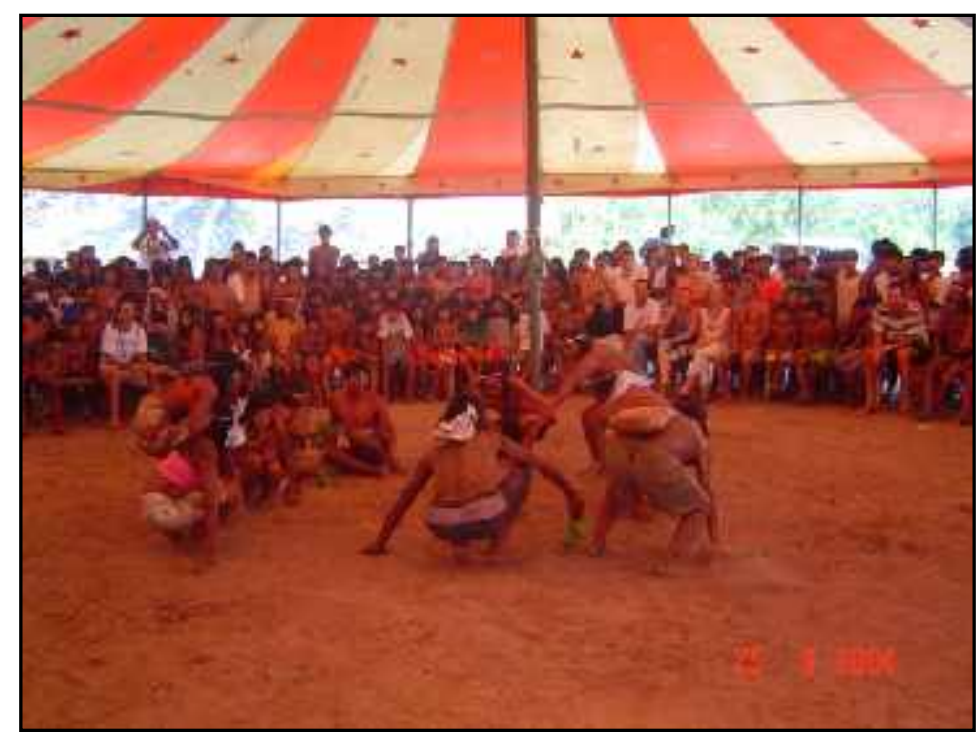

Fonte: Autor, 2004.

O lazer durante os dias de realização da VI Feira Krahô seguiu a lógica da tradição dos anfitriões. A programação era a seguinte: das $5 \mathrm{~h} 30 \mathrm{~min}$ às $6 \mathrm{~h}$ banho de rio; das $7 \mathrm{~h}$ às $9 \mathrm{~h}$ café da manhã; das $9 \mathrm{~h}$ às $12 \mathrm{~h} 30$ min exposição e trocas de sementes entre as etnias; das $12 \mathrm{~h} 30 \mathrm{~min}$ às $14 \mathrm{~h}$ outro banho de rio e almoço; das $14 \mathrm{~h}$ às $17 \mathrm{~h} 30 \mathrm{~min}$ exposição e trocas de sementes; das $17 \mathrm{~h} 30 \mathrm{~min}$ às $19 \mathrm{~h}$ outro banho de rio e jantar; das $19 \mathrm{~h}$ às $22 \mathrm{~h} 30 \mathrm{~min}$ reunião entre os participantes da Feira; das 22h30min às 6 h cantorias no pátio.

Durante a realização da VI Feira Krahô, as atividades cotidianas entre os índios e entre os índios e os não-índios ficaram divididas entre as atividades de lazer, a exposição de sementes, a troca de sementes, as apresentações culturais, as cantorias no pátio e a venda do artesanato.

A seguir, são apresentadas imagens do banho de rio, atividade que conta na programação do evento, e de turistas próximos às suas barracas no intervalo entre as demais atividades. 
Figura 23 - Banho de Rio no Ribeirão Riozinho

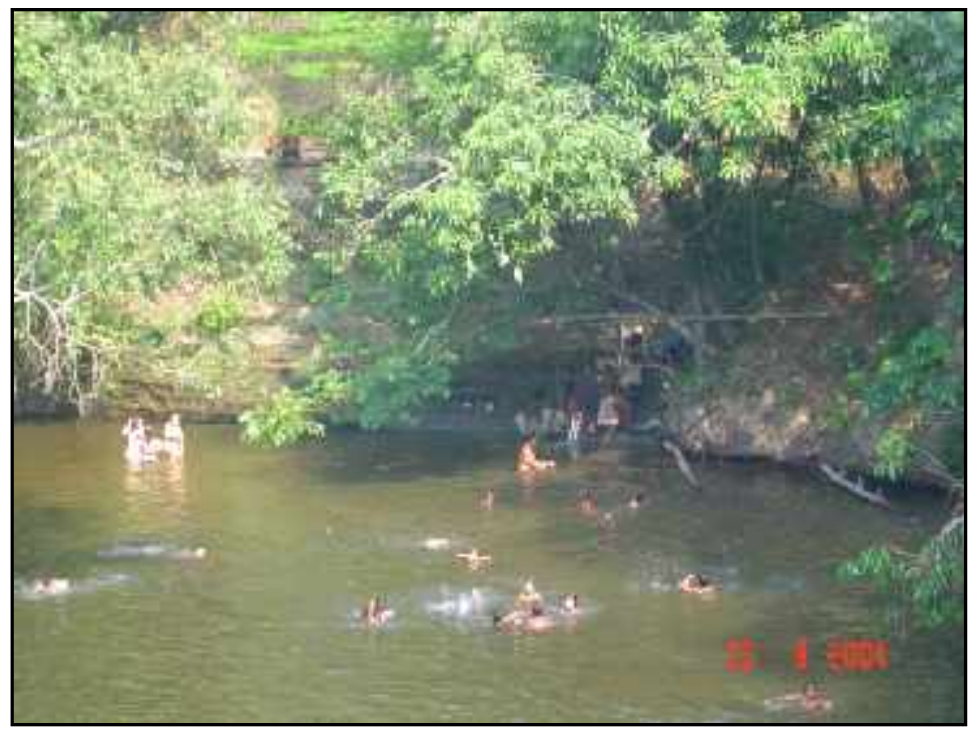

Fonte: Autor, 2004.

Figura 24 - Acampamento Kapey

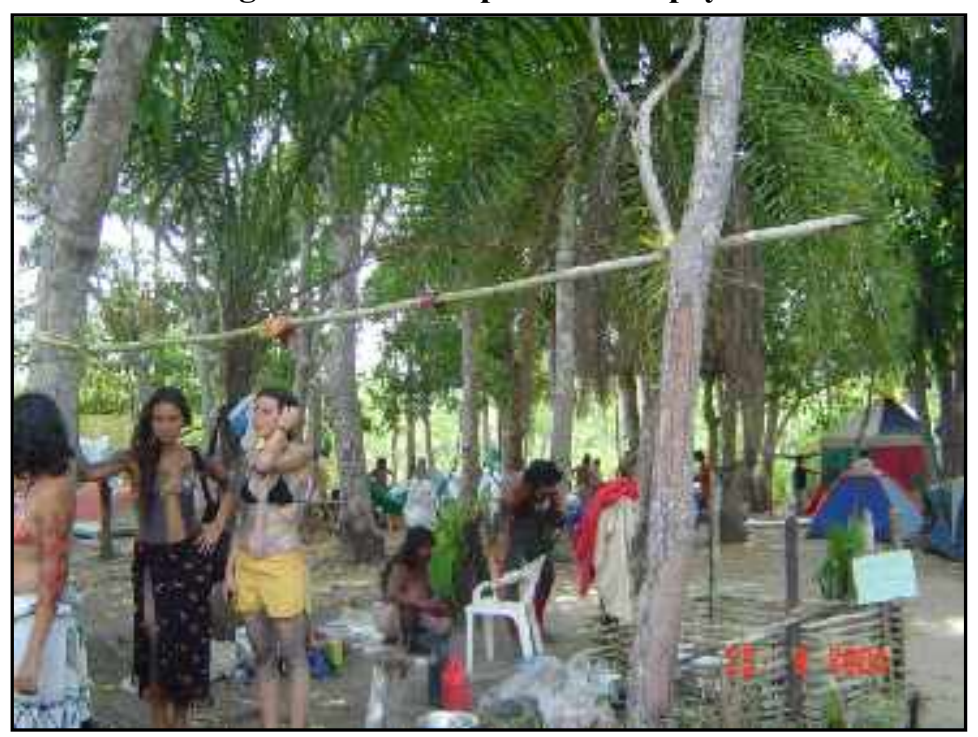

Fonte: Autor, 2004. 
Vale notar que a figura 24 revela o interesse dos turistas pela participação nas manifestações culturais, já que as pinturas corporais significam o envolvimento no evento e a disposição em vivenciar um momento de valorização da cultura Krahô durante a realização das Feiras. O evento acontece durante três (03) dias com intensas atividades intercaladas entre os dias e as noites.

Como se pode observar na figura apresentada a seguir, a organização do evento elaborou um quadro de avisos destinados aos turistas, contendo regras comportamentais básicas.

Figura 25 - Quadro informativo para os turistas

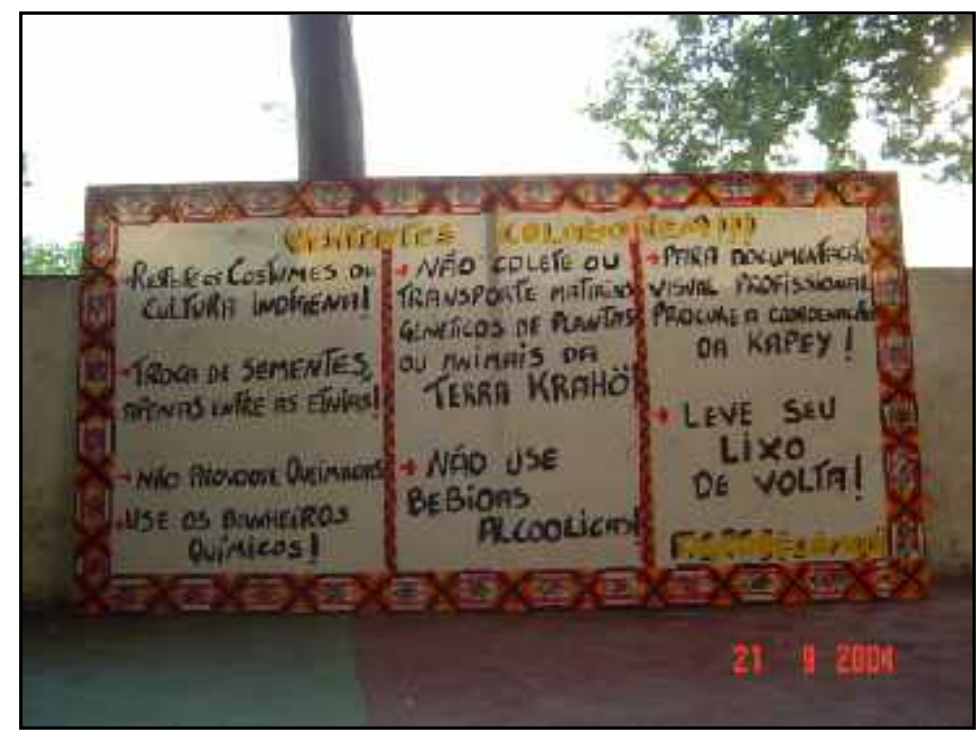

Fonte: Autor, 2004.

A VI Feira Krahô de Sementes revelou que a população indígena Krahô tem acumulado experiências, principalmente no que se refere às exposições de artesanato e de sementes. Baseando-se em tais experiências, a comunidade Krahô estabeleceu que o artesanato estaria à venda para os turistas, mas que as sementes tradicionais deveriam ser trocadas apenas entre as populações indígenas, conforme evidencia o quadro apresentado anteriormente na figura 25. Era, portanto, proibida a troca de sementes entre os índios e os não-índios, uma vez que as sementes tradicionais não poderiam ser retiradas dos territórios indígenas. Assim, nota-se, novamente, que a Feira Krahô de Sementes Tradicionais contribui para a valorização da cultura dos Krahô e para a conservação do meio ambiente. 
Observa-se, na figura 26, a exposição de Artesanato e Sementes:

\section{Figura 26 - Exposição de Artesanato e Sementes}

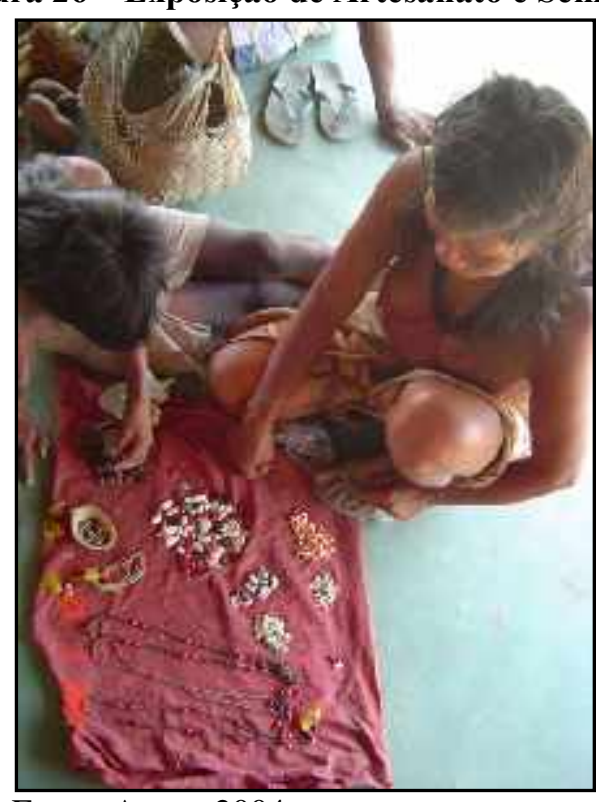

Fonte: Autor, 2004.

A arte de fazer o artesanato pode ser considerada uma ocupação da população indígena Krahô. Os índios se deslocam das aldeias para as roças principalmente para: cultivar a terra; coletar mandioca, inhame, batata, arroz, abóbora, etc.; caçar; coletar frutos; e coletar material para fazer o artesanato. A arte de praticar a agricultura, por sua vez, está associada à arte de fazer o artesanato, que também está atrelada à arte de realizar as manifestações culturais. Durante a realização dos cerimoniais que compõem o calendário de rituais anual dos Krahô, se pode notar a duração e o significado de cada ritual.

Os pesquisadores da Embrapa também contribuíram para a realização da Feira, organizando a apresentação dos resultados dos projetos de pesquisa que estão em desenvolvimento. Nessa lógica, ocorreu também a distribuição de novas sementes tradicionais e de mudas de palmeiras, caju e piqui, entre outras; cada aldeia recebeu uma caixa contendo algumas mudas.

Com a introdução de novas espécies de batata, milho, piqui, caju, laranja, acerola, jaca, limão, mandioca, banana, mamão, feijão, fava, abóbora e arroz, entre outras, objetiva-se aumentar a variedade de espécies de produtos cultivados pelos Krahô, o que faz com que a 
agricultura tradicional se mostre cada vez mais diversificada, com várias espécies de plantas sendo cultivadas numa mesma roça.

Nesse sentido, observa-se, a seguir, a troca de sementes entre os índios de diferentes etnias sendo efetivada.

Figura 27 - Troca de Sementes entre os Krahô e os Kaxinawa

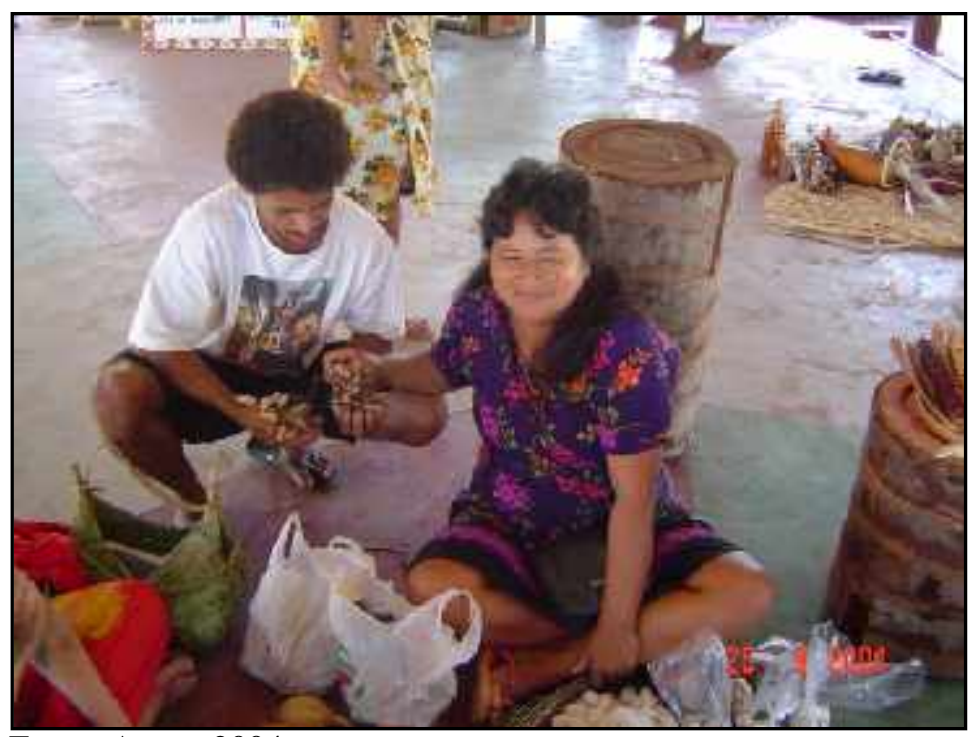

Fonte: Autor, 2004.

O propósito da troca de sementes entre as etnias é que a iniciativa dos Krahô sirva de modelo de agricultura ecológica e socialmente sustentável a ser transferido para outras populações indígenas do país e do exterior. Compreende-se, assim, que a realização dessas Feiras constitui uma experiência específica e de grande validade, servindo de exemplo para as políticas públicas setoriais relativas às populações indígenas.

As roças do território Krahô ficam localizadas no entorno das aldeias. Para conhecer a agricultura tradicional, portanto, faz-se necessário deslocar-se para a área adjacente às aldeias num raio que varia entre um (01) e seis (06) quilômetros de distância. Nesse sentido, as trilhas ecológicas foram formadas a partir da organização da agricultura Krahô; isto é, as aldeias são circundadas pelo espaço da Agricultura Krahô, onde estão localizadas as roças das famílias gerais e das famílias individuais. $\mathrm{Na}$ figura 28 pode-se observar parte das supracitadas trilhas: 
Figura 28 - Trilhas Ecológicas

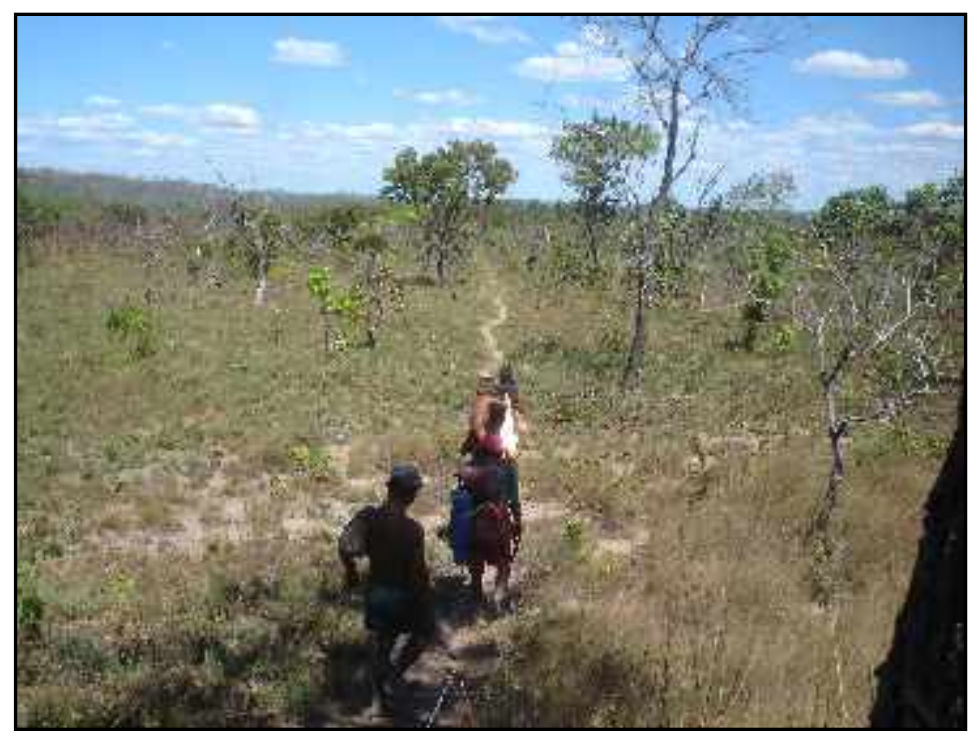

Fonte: Autor, 2005.

As trilhas ecológicas Krahô revelam potencialidades de recursos turísticos, principalmente para a prática do ecoturismo. Por meio delas o turista pode manter contato com a natureza. Foi possível identificar que os visitantes caminham pelas trilhas ecológicas Krahô partindo do local da sede da Kapey rumo às seguintes aldeias: Santa Cruz, Pedra Branca, Campo Lindo e Manoel Alves. Todas as aldeias Krahô possuem um roteiro para o turismo durante o ano todo.

O cotidiano dos Krahô é marcado por pequenos deslocamentos, tais como: da aldeia para a roça; da aldeia para a área de caçada; da aldeia para a pesca; e da aldeia para a coleta de frutos do cerrado, entre outros trajetos. Os deslocamentos ocorrem com mais freqüência entre a aldeia e a roça, com o objetivo de cuidar dos cultivos e de coletar mandioca, banana, feijão, fava, arroz, batata doce, inhame, caju, laranja, feijão andu, milho, mamão, abacaxi e fumo, entre outros.

Os Krahô não acumulam grandes quantidades de alimentos na aldeia, de modo que nela conservam apenas os mantimentos que serão consumidos em no máximo três dias. Ainda sobre a alimentação dos Krahô, pode-se afirmar é bastante natural, pois é a comunidade que cultiva quase todos os alimentos de que necessitam. No cair da tarde, é comum encontrar os índios Krahô retornando de suas roças para as aldeias, caminhando com o cofo (espécie de 
cesto alongado) cheio de batata doce, inhame, banana e mandioca, entre outros alimentos, além de material para fazer artesanato, para o consumo da família por alguns dias.

Quando a roça está à cerca de seis (06) quilômetros de distância da aldeia, os Krahô constroem um racho para proteger da chuva e do sol algumas panelas, madeiras para queimar e ferramentas para o trabalho na agricultura. O rancho utilizado para proteção serve também de local para preparar a alimentação durante o período de permanência na roça. Nesse sentido, o rancho da roça pode ser considerado uma segunda casa. O cacique Valdo Krahô, da aldeia Lagoinha, por exemplo, tem três roças. A primeira e mais antiga foi formada há três ou quatro anos; a segunda foi aberta há um ou dois anos; e a terceira e mais recente ainda está sendo preparada para o cultivo.

A agricultura tradicional Krahô pode ser considerada bastante diferente da agricultura moderna e industrializada. Aquela, ao contrário desta, concentra diversas espécies de cultivos em um único local, tais como mandioca, banana, milho, batata doce, caju, arroz, fava, feijão, abóbora e inhame, entre outros. Assim, pode-se afirmar que os Krahô apresentam uma proposta alternativa e de ruptura com a agricultura moderna e industrializada.

A seguir, são apresentadas algumas imagens da Agricultura Tradicional Krahô.

Figura 29 - Agricultura Tradicional Krahô

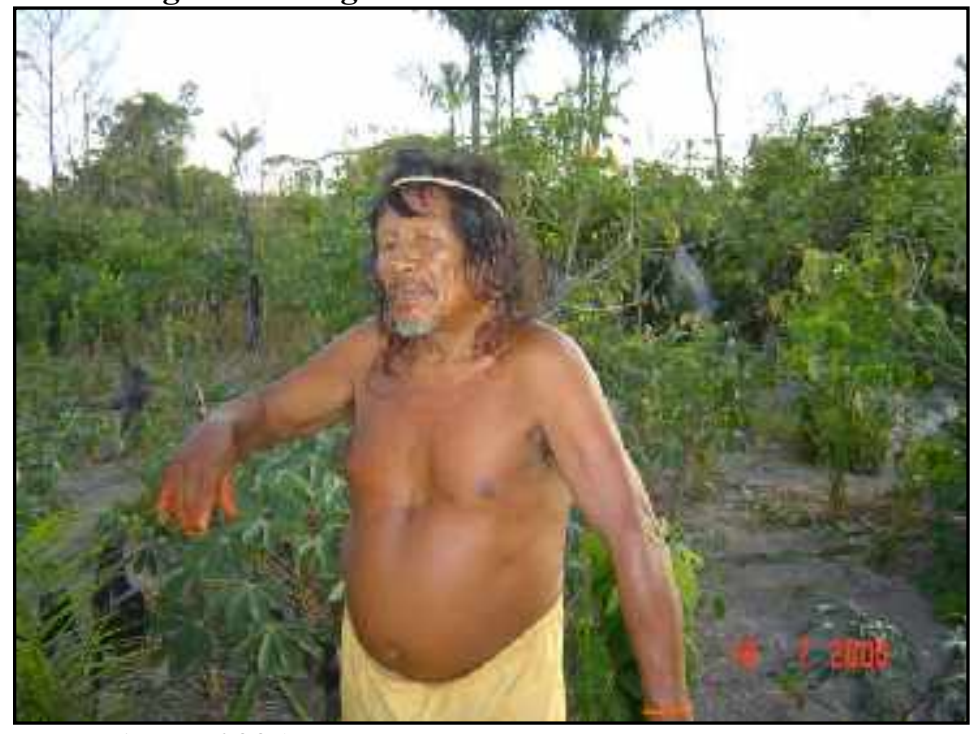

Fonte: Autor, 2005. 
Figura 30 - Agricultura Tradicional Krahô

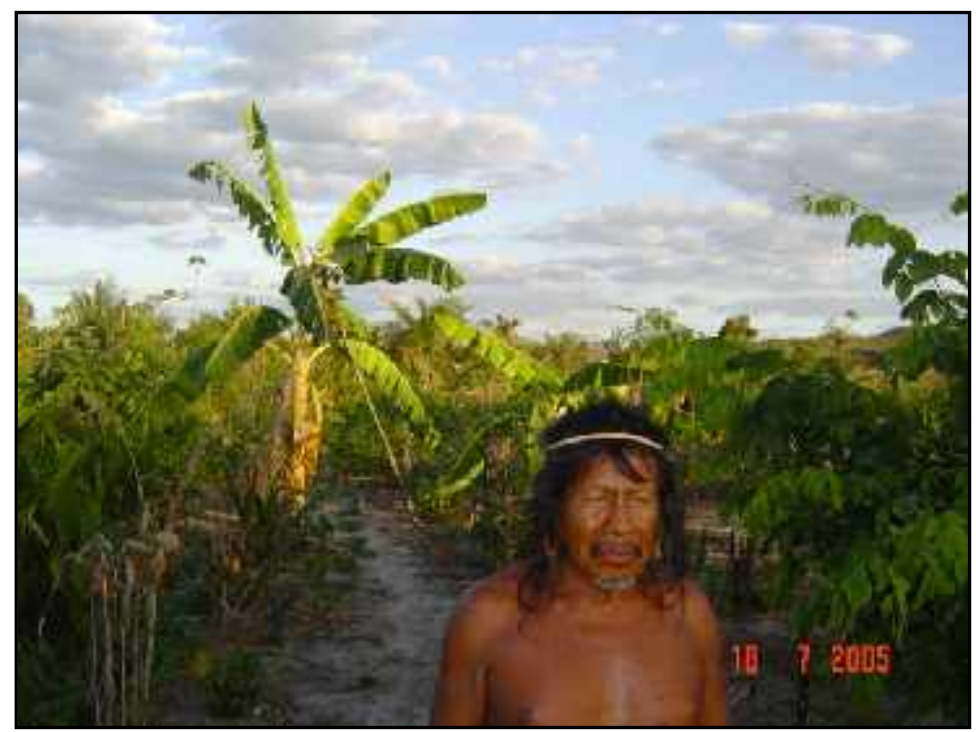

Fonte: Autor, 2005.

Figura 31 - Cultivo de Batata doce

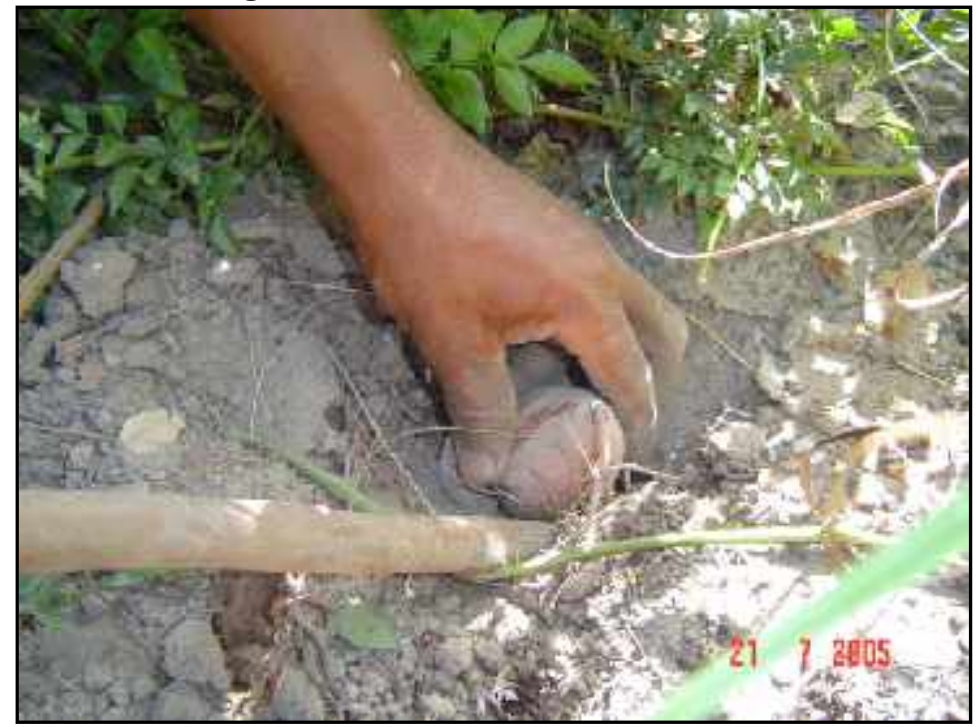

Fonte: Autor, 2005. 
Figura 32 - Método de Conservação das Variedades de Espécies de Mandioca para o plantio

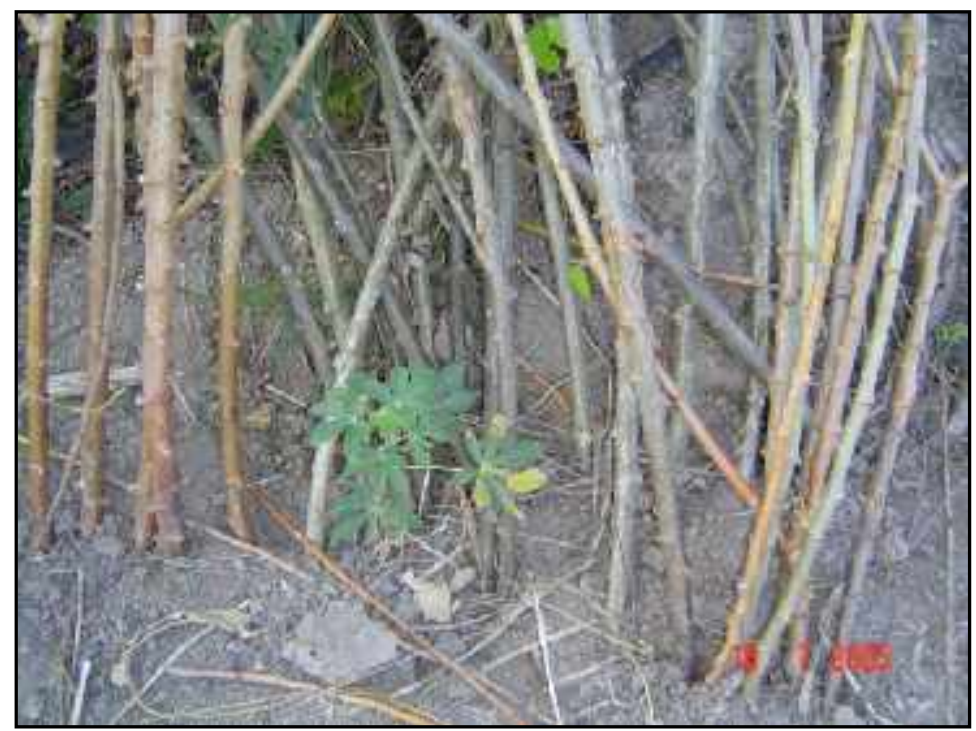

Fonte: Autor, 2005.

\subsubsection{Artesanato Krahô, Feiras Krahô de Sementes Tradicionais e o turismo}

O artesanato Krahô tornou-se conhecido no mercado nacional e internacional. De uma parte, as Feiras Krahô de Sementes Tradicionais contribuíram no sentido de divulgar o artesanato e, de outra, os prêmios recebidos no Brasil e no Exterior por essa comunidade indígena também promoveram a sua valorização cultural. Como se sabe, os Krahô divulgam a sua cultura por meio da venda do artesanato em suas mobilidades internas e externas ao país, quando viajam para Brasília, São Paulo, Rio de Janeiro, entre outras cidades, assim como para as urbes européias, entre elas Paris, Milão, Veneza, Roma e Noruega.

Os Krahô dedicam-se à arte de fazer artesanato quando estão em suas casas, nas aldeias, de modo que quando vão trabalhar na roça (fazendo a preparação da terra, o plantio, os cuidados com a cultura das plantações e a colheita) aproveitam para conseguir o material necessário para produzi-lo. As esteiras, por exemplo, são feitas de folhas de buriti ${ }^{75}$, uma espécie de palmeira do cerrado. O artesão Luis Pẽnkrö Krahô, da aldeia Santa Cruz, tem próximo à sua casa um espaço de trabalho, onde faz a Cahti Krahô (esteira Krahô). Dessa forma, este artífice valoriza a cultura indígena Krahô e, concomitantemente, obtém uma renda com a venda do artesanato.

\footnotetext{
${ }^{75}$ Mauritia flexuosa L.; nome em Krahô, Krow; nome vulgar, Buriti.
} 
O valor de uma esteira no mercado local e regional varia entre Trinta Reais ( $R$ \$ 30,00) e Cinqüenta Reais (R\$ 50,00). A lógica da comercialização desse artefato parece ser o atendimento à demanda de mercado do artesanato indígena no Brasil; por isso é comum entre os Krahô a prática da arte de fazer artesanato. ${ }^{76}$

Nas Figuras 33 e 34, apresentadas a seguir, pode-se verificar a referida esteira Krahô sendo produzida.

Figura 33 - Arte de fazer a Esteira Krahô

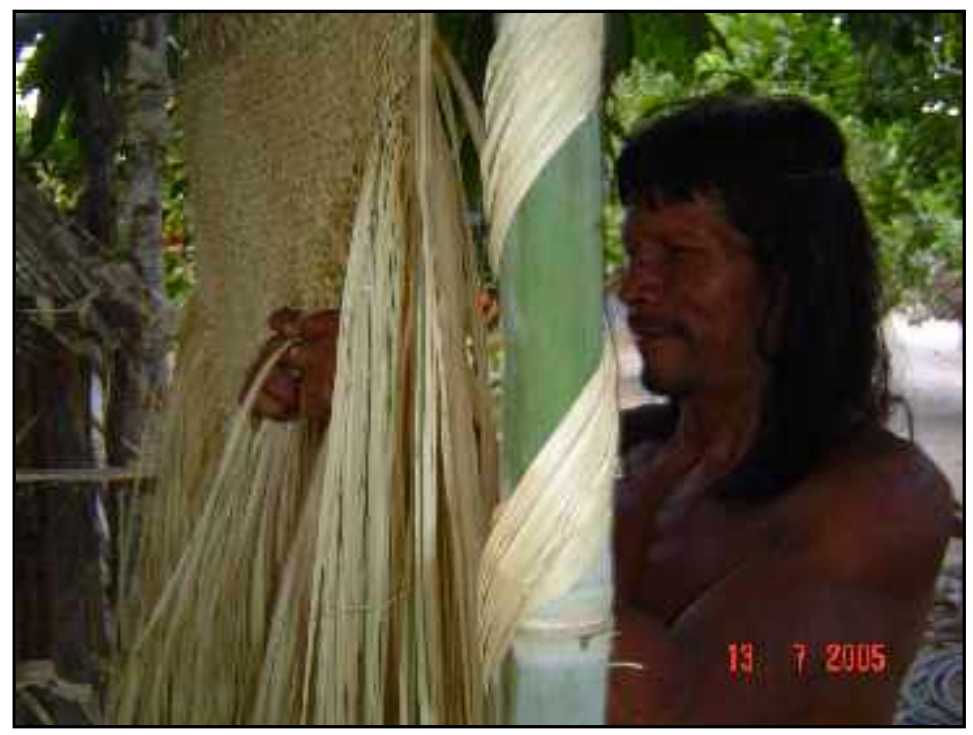

Fonte: Autor, 2005.

\footnotetext{
${ }^{76}$ De acordo com Dodanin Krahô: "Essa esteira é feita pelos homens. Quando um homem quer fazer uma esteira, ele vai primeiro ao brejo e tira o olho de buriti. Depois de feita, ela é usada para dormir por homens, mulheres e crianças." (DODANIN KRAHÔ, 1998, p.37).
} 
Figura 34 - Arte de fazer a Esteira Krahô

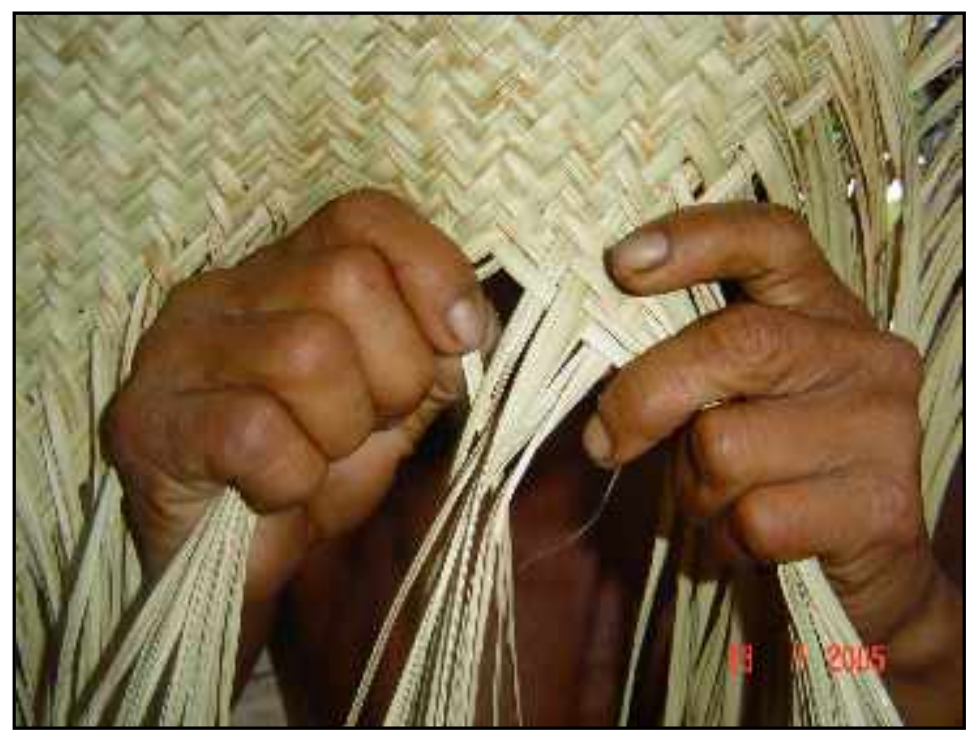

Fonte: Autor, 2005.

A arte de fazer as pinturas corporais pode ser considerada outra atividade voltada para a valorização cultural. Entre os materiais que são utilizados destaca-se o urucum, com sua cor bastante avermelhada, como se pode observar nas figuras exibidas a seguir. Essa tonalidade é marcante na pele da população indígena Krahô, principalmente quando realizam os rituais e as corridas da flecha e de tora. 
Figura 35 - Preparação do Urucum

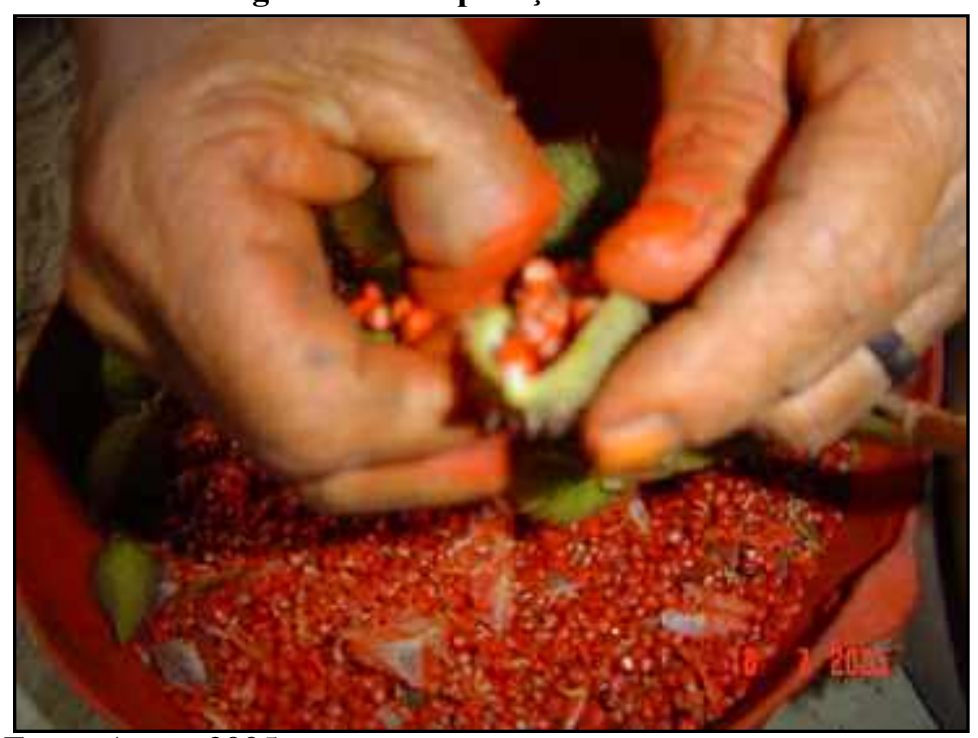

Fonte: Autor, 2005.

Figura 36 - Preparação do Urucum

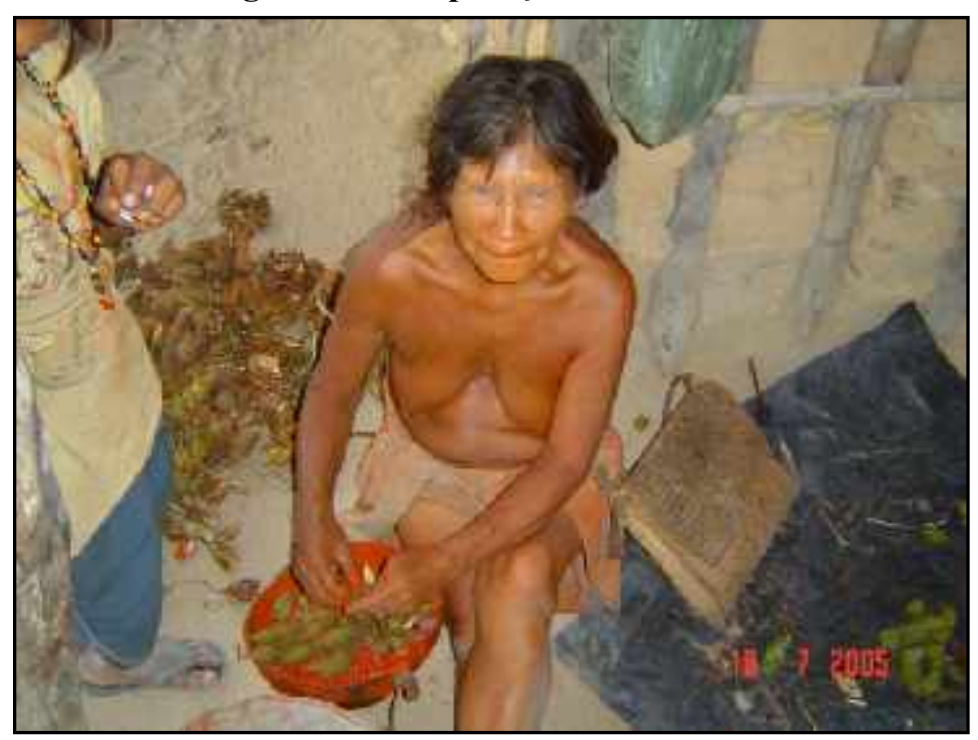

Fonte: Autor, 2005. 
Figura 37 - Urucum preparado para a arte de fazer as pinturas corporais Krahô

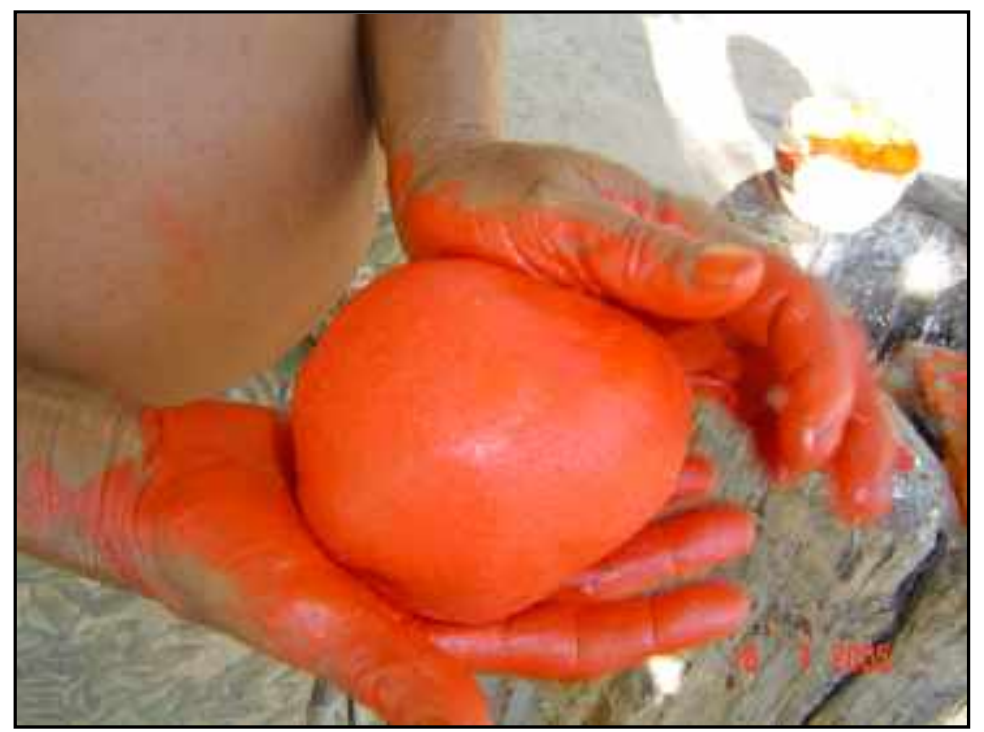

Fonte: Autor, 2005.

A arte de fazer o artesanato, por sua vez, está relacionada à construção de objetos de uso cotidiano dos Krahô. O livro organizado por Poleck (1998), que contém textos e desenhos de Dodanin Krahô, intitulado "Ampo Itajê Nõ CA Atỳj Amcro Nõ Kãm to Apê: objetos do dia-a-dia", contribui para a compreensão da relação entre os artesanatos Krahô e os objetos de uso atual dos Krahô, entre os quais: Maco, Cajpo, Côhpip, Cuhy Mã Ihcaijpêr Xá, Kwỳc, Cahuw me Ihkrã Kô, Panẽr, Cuhkõn e Cahti. ${ }^{77}$

Outro livro que aborda tal relação - cujo autor pertence, inclusive, à essa comunidade indígena - é o de Krahô (1997), intitulado “Amjĩ Kĩn Krahó, Mẽ Hokor Xá na Itajê; Festas Krahô: objetos e instrumentos musicais". Entre os objetos e os instrumentos musicais relacionados nesta obra estão: Amjĩ Kĩn, Cuhtoj, Patwỳ, Pyry Jakà, Cuhkõnre, Xy, Cukẽn Jõhxy, Pan Japy, Kruwaxwa, Crate, Côhkrit, Põhy Jô Crow Jaren Xá. ${ }^{78}$

Os artesanatos feitos pelas mãos Krahô podem ser considerados, portanto, objetos de uso diário dos índios dessa comunidade. Compreende-se também que as Feiras Krahô de

\footnotetext{
${ }^{77}$ Tradução dos nomes dos objetos do dia-a-dia dos Krahô, segundo Krahô (1998): "Maço, Cesta, Esteira de Rapaz, Abano, Girau, Pilão, Panela, Cabaça, Esteira.”

${ }^{78}$ Tradução dos Objetos e Instrumentos Musicais, segundo Krahô (1997): "Festa da Batata, Tora da Festa da Batata, Maracá, Buzina de Cabaça, Apito, Cinto, Apito de Cabacinha, Cinto, Cinto de Tiririca, Colar de Pena de Arara, Bastão, Colar de Cabacinha, Côhkrit, Festa do Milho."
} 
Sementes Tradicionais contribuem para a divulgação desses artesanatos, promovem a autoestima dos Krahô e, ainda, possibilitam a venda dos artefatos para os turistas.

\subsection{IMPASSES EXISTENTES ENTRE EMBRATUR, FUNAI, MMA E POPULAÇÕES INDÍGENAS BRASILEIRAS}

Atualmente, há uma articulação de políticas públicas setoriais no âmbito do governo federal envolvendo a Funai, a Embratur, o MMA e os povos indígenas, no intuito de se construir um programa de turismo nacional que atenda à demanda do mercado nacional e internacional. O turismo foi bastante discutido no sentido econômico, ou seja, como uma atividade econômica a ser implantada nos territórios indígenas. Logicamente, não existe um projeto que defina como deve ser o turismo em territórios indígenas; portanto, continua o impasse entre o governo federal, a FUNAI, a Embratur, o MMA e as populações indígenas e não-indígenas (brasileiros e estrangeiros).

Nesse sentido, vale esclarecer que a proposta do Ministério do Meio Ambiente (MMA) foi construída com o apoio de antropólogos, indigenistas, profissionais do turismo e comunidades indígenas do estado do Acre. Por isso o Manual Indígena de Ecoturismo (1997) não expressa objetivos comuns entre os órgãos do governo federal responsáveis pelo turismo, pelo meio ambiente e pelas populações indígenas.

Pode-se afirmar que o turismo em territórios indígenas tem uma história, uma vez que diversos eventos são organizados nestas terras, contando com a participação de poucos grupos de turistas. Como se pôde verificar no capítulo dois, várias populações de índios ao redor do mundo estão apostando no turismo de pequenos grupos de visitantes, de modo que estão construindo propostas originais para oferecer o turismo em territórios indígenas.

Entre as conquistas políticas que envolveram os povos indígenas, pode-se citar o Artigo 161 do Código Penal, o Estatuto do Índio de 1973 e a Convenção da OIT Nº 169, entre outras. Nesta lógica, se pode observar que as populações indígenas estão lutando em prol da elaboração de leis que estejam de acordo com as reivindicações dos movimentos sociais indígenas do país. Apenas as etnias que lutam pelo Estado e contra o Estado na defesa dos seus interesses estão apresentando fortes indícios de reterritorialização (resistência) na gestão do território e do turismo. As etnias que ainda acreditam que o Estado pode resolver todos os 
problemas das populações indígenas brasileiras podem ser consideradas as que se encontram desterritorializadas (sem poder de gestão) dentro dos seus territórios. Nota-se, assim, que o turismo em territórios indígenas no Brasil ainda se encontra em sua fase inicial de organização e de gestão.

Durante a pesquisa de campo realizada entre os anos de 2004, 2005 e 2006, foi possível identificar que as comunidades indígenas Krahô das dezoito (18) aldeias estão organizadas para o turismo. Entre as experiências vivenciadas no cotidiano dos Krahô com os turistas, se pode mencionar: Guias de Pesquisa de Campo, Guias Turísticos, Confecção de Artesanato Sob Encomenda, Comercialização de Artesanato, Cantorias, Danças, Teatro Krahô, Rituais, Pinturas Corporais, Corridas de Tora, Corridas da Flecha, Futebol, Feira Krahô de Sementes Tradicionais, entre outras.

Tendo em vista o exposto, compreende-se que a construção de material didático sobre a potencialidade turística no Território Krahô pode contribuir para a formação permanente de Guias Turísticos Krahô, o que reforçaria a consolidação da organização do turismo entre os Krahô.

\subsection{A CONSTRUÇÃO DE MATERIAL DIDÁTICO SOBRE O TURISMO EM TERRITÓRIOS INDÍGENAS}

De certa maneira, a construção de material didático sobre o turismo tornou-se uma necessidade, principalmente para que as comunidades indígenas possam construir as suas próprias referências sobre o que é turismo, pois, como se pôde verificar ao longo deste estudo, o turismo indígena e o turismo em territórios indígenas estão acontecendo a partir da iniciativa das próprias populações indígenas.

$\mathrm{O}$ material didático sobre o turismo em território indígena deve ser elaborado em conjunto com as comunidades indígenas e considerando-se as singularidades de cada etnia. Poderia, ainda, ser incorporado aos demais materiais didáticos das escolas indígenas, seguindo a proposta pedagógica do "Manual Indígena de Ecoturismo", publicado pelo Ministério do Meio Ambiente em 1997, e ampliando a participação das comunidades de índios, questão que ficou pouco evidente no referido manual. 
Para evitar que todos os bens de valor e de uso se tornem de troca, o turismo em território indígena pode ser pensado como mais uma atividade da estrutura social e econômica Krahô, e não como uma atividade em detrimento das outras existentes. Nesta lógica, o Projeto "Resgate, Valorização e Comercialização do Artesanato Krahô", financiado pela Fundação Banco do Brasil, permitiu: a construção da Casa do Artesanato, que possibilita a coleta dos artesanatos nas comunidades indígenas sob encomenda para a venda; a produção do CD Músicas Krahô, com canções do repertório de cantos e rituais Krahô; a produção do Vídeo "Krahô os filhos da terra" - em 1993, ano da criação da KAPEY -, que traz um relato da vida dos povos indígenas Krahô; a publicação do Livro Infantil "Catxêkwyj”,79, que narra o mito da Catxêkwyj, a estrela-mulher que ensinou a agricultura aos povos indígenas Krahô, possuindo ilustrações com desenhos de artistas Krahô; a produção dos artesanatos (colares, pulseiras, esteiras, entre outros $)^{80}$; a edição do livro “Ampo Itajê Nõ CA Atỳj Amcro Nõ Kãm to Apê: objetos do dia-a-dia" ${ }^{\sharp 1}$, que serve de referência para se compreender o artesanato Krahô; e a publicação do livro “Amjĩ Kĩn Krahó, Mẽ Hokor Xá na Itajê; Festas Krahô: objetos e instrumentos musicais" $" 82$.

O supracitado Projeto desenvolveu, ainda, o material de divulgação dos resultados da pesquisa da Embrapa junto aos Krahô, que pode ser considerado, por um lado, uma forma de registro dos resultados dos projetos desenvolvidos no território indígena Krahô e, por outro, um material educativo a ser utilizado nas escolas. ${ }^{83} \mathrm{O}$ material didático sobre a diversidade do artesanato Krahô, com desenhos e explicações acerca dos seus significados, pode contribuir para a organização do turismo e para a venda do artesanato. Pode-se considerar que o turismo

\footnotetext{
${ }^{79}$ POHKROK, A. Catxêkwyj; a estrela mulher: um mito Krahô. Goiânia: UFG, Kapey e Fundação Cultural do Tocantins, 1999.

80 "Está sendo produzido um catálogo sobre o artesanato Krahô para divulgação no Brasil e no exterior. Este projeto é financiado pela Fundação Banco do Brasil." (Pesquisa de campo, julho de 2004).

${ }^{81}$ KRAHÔ, D. Ampo Itajê Nõ CA Atỳj Amcro Nõ Kãm to Apê: objetos do dia-a-dia. Textos e Desenhos de Dodanin Krahô. Organização e Coordenação do Projeto de Lydia Poleck Goiânia. Coleção de Textos Indígenas, Série Cultura, 1998.

${ }^{82}$ KRAHÔ, D. Amjĩ Kĩn Krahó, Mẽ Hokor Xá na Itajê; Festas Krahô: objetos e instrumentos musicais. Organização e Coordenação do Projeto de Lydia Poleck. Coleção de Textos Indígenas, Série Cultura, Goiânia, 1997.

${ }^{83}$ EMBRAPA. Krahô: Etnobiologia, Conservação de Recursos Genéticos e Segurança Alimentar. Brasília: Kapey, Funai, Ministério da Justiça, Ministério da Agricultura e Abastecimento, Julho/2003. $6 \mathrm{p}$.
} 
no território indígena Krahô está acontecendo, verificando-se o início de um plano de gestão sendo colocado em prática pelas comunidades indígenas.

A elaboração de material didático indígena Krahô sobre o turismo pode promover a organização do turismo, assim como a sua divulgação entre as demais populações indígenas e não-indígenas. Compreende-se que o livro sobre o turismo no território indígena Krahô pode seguir a lógica das publicações dos livros Krahô, isto é, a linguagem utilizada nos livros publicados por Dodanin Krahô (1997 e 1998) valorizou a Língua Timbira, o Dialeto Krahô e a língua portuguesa. Assim, a linguagem, os textos, os desenhos e as ilustrações do material didático sobre o turismo no território Krahô deve ser acessível num primeiro plano à população indígena Krahô.

\subsection{AS ASSOCIAÇÕES INDÍGENAS KRAHÔ E A ORGANIZAÇÃO DO TURISMO}

As Associações Krahô estão divididas em sete (07) entidades, cada uma representando de uma forma diferente a população indígena Krahô. São elas: Kapey (representa todas as aldeias), Mãkrare (representa a Aldeia Nova), Awkêre (representa a Aldeia Cachoeira), Inxê-Cati (representa as Aldeias Lagoinha, Santa Cruz, Serra Grande, Forno Velho, Morro do Boi, Riozinho, Macaúba e Galheiro), Wõkram (representa as Aldeias Rio Vermelho e Bacuri), Awkê (representa as Aldeias Pedra Branca e São Vidal) e Pretori (representa as Aldeias Manoel Alves Pequeno, Pedra Furada, Água Branca e Campos Lindo).

As dezoito (18) aldeias Krahô estão articuladas em associações, as quais foram organizadas pelas próprias comunidades indígenas das aldeias. Como já visto anteriormente, a Kapey- União das Aldeias Krahô congrega todas as aldeias e possui o maior número de projetos aprovados (financiamento e pesquisa) e implementados. A Associação Inxê-Cati, com sede na Aldeia Serra Grande, congrega oito (08) aldeias, mas não possui projetos (pesquisa e financiamento) aprovados. As demais associações estão buscando alcançar a aprovação de projetos das comunidades indígenas.

As Associações Indígenas Krahô mais antigas foram criadas entre os anos de 1979 e 1993; as demais podem ser consideradas de origem mais recente. Em 1979 foi fundada a Associação Makraré, na Aldeia Galheiros, a qual, mais tarde, se mudaria para a Aldeia Nova, onde se encontra atualmente. Pode-se notar que essa associação tem grande importância, pois 
possui projetos aprovados junto aos PDPI e articula a elaboração de novos projetos junto às lideranças políticas indígenas Krahô e às Organizações Não-Governamentais (entre as quais o Centro de Trabalhador de Indigenista, cuja sede fica na cidade de Carolina - MA).

Em 1993, ocorreu a fundação da Kapey- União das Aldeias Krahô. Pode-se afirmar que essa associação tem contribuído bastante para as conquistas das populações indígenas Krahô e das demais associações indígenas.

De certa maneira, todas as associações Krahô atuam em conjunto quando enfrentam problemas que podem ser considerados prejudiciais para essa população indígena. Nesse sentido, parece que à medida que os interesses das comunidades são atendidos, o que resulta do trabalho realizado pelas associações, estas adquirem ainda mais força política. No entanto, em função de uma série de dificuldades técnicas, as associações indígenas não conseguem apresentar retorno de imediato para as suas comunidades.

A seguir, pode-se observar as associações indígenas Krahô e as comunidades por elas representadas.

Tabela 05 - Associações Indígenas Krahô

\begin{tabular}{|l|l|c|}
\hline \multicolumn{1}{|c|}{ Associações Indígenas Krahô } & \multicolumn{1}{|c|}{ Comunidades Indígenas } & $\begin{array}{c}\text { Número de Aldeias } \\
\text { por Associação }\end{array}$ \\
\hline $\begin{array}{l}\text { 1- Kapey- União das Aldeias } \\
\text { Krahô }\end{array}$ & Representa todas as aldeias & 18 \\
\hline 2- Associação Inxê-Cati & $\begin{array}{l}\text { Aldeias Lagoinha, Santa Cruz, } \\
\text { Serra Grande, Forno Velho, } \\
\text { Morro do Boi, Riozinho, } \\
\text { Macaúba e Galheiro }\end{array}$ & 08 \\
\hline 3- Associação Makraré & Aldeia Nova & 01 \\
\hline 4- Associação Awkêre & Aldeia Cachoeira & 01 \\
\hline 5- Associação Awkê & $\begin{array}{l}\text { Aldeias Pedra Branca e } \\
\text { São Vidal }\end{array}$ & 02 \\
\hline 6- Associação Wõkram & Aldeias Rio Vermelho e Bacuri & 04 \\
\hline $\begin{array}{l}\text { 7- Associação Pretori (em fase } \\
\text { de criação) }\end{array}$ & $\begin{array}{l}\text { Aldeias Manoel Alves Pequeno, } \\
\text { Água Branca, Campos Lindo e } \\
\text { Pedra Furada }\end{array}$ & 02 \\
\hline
\end{tabular}

Fonte: Pesquisa de Campo, 2004, 2005 e 2006. 
A organização do turismo em territórios indígenas tem a sua base de sustentação nas Associações Indígenas, pois nestas as comunidades das aldeias se encontram ordenadas de acordo com a estrutura econômica e social de cada etnia. São elas que, em conjunto com as comunidades locais, possibilitam a construção de propostas singulares. Portanto, pode ser por meio das Associações Indígenas que a organização do turismo em territórios indígenas adquirirá as características de um turismo comunitário.

Entre as associações Krahô que estão se organizando para o turismo em territórios indígenas destacam-se: Kapey, Inxê-Cati, Awkê e Pretori. Atualmente, o turismo no território indígena Krahô está acontecendo nas Aldeias Manoel Alves Pequeno, Pedra Branca, Santa Cruz, Cachoeira e na sede da Kapey (durante a realização das Feiras Krahô de Sementes Tradicionais).

A aldeia Manoel Alves Pequeno está localizada a apenas dez (10) quilômetros da cidade de Itacajá (TO), o que facilita o acesso e o contato da comunidade com os turistas. Com relação à aldeia Pedra Branca, esta pode ser considerada uma povoação antiga e é conhecida por ser o local de origem de lideranças políticas indígenas; além disso, é esta aldeia que abriga a Casa da Cultura, uma das ações da associação Awkê. A aldeia Santa Cruz, por sua vez, está localizada a setenta (70) quilômetros da cidade de Itacajá, sendo que o acesso da aldeia à cidade e vice-versa pode ser considerado fácil, utilizando-se a estrada de terra. A comunidade desta aldeia se relaciona com as comunidades de outras aldeias, com a Kapey, com Organizações Não-Governamentais e com Universidades; por isso se tornou uma aldeia que possui uma organização para o turismo em territórios indígenas.

Já a aldeia Cachoeira, assim como a aldeia Pedra Branca, possui um histórico de formação de lideranças políticas; por isso tem contatos com pesquisadores, técnicos da Embrapa, estudantes universitários, missionários e outros. E, por último, a Kapey, devido ao histórico de sua formação e atuação, tornou-se um lugar de referência para a população indígena Krahô, para outras populações indígenas brasileiras e internacionais, assim como para os profissionais que trabalham de alguma forma em prol das populações indígenas. 


\section{À GUISA DA CONCLUSÃO}

Esta pesquisa orientou-se pelos debates teóricos e metodológicos sobre território, em específico pelas abordagens do território, da desterritorialização e da reterritorialização, enfocando a mobilidade social e a constituição de multiterritorialidades. Dentro desta lógica, procurou-se analisar, compreender e identificar o turismo indígena e o turismo em territórios indígenas.

Por um lado, o turismo indígena pode ser interpretado a partir do turismo emissivo indígena, isto é, dos deslocamentos dos territórios indígenas para as cidades locais, regionais, nacionais e internacionais. Por outro lado, o turismo em territórios indígenas pode ser definido como aquele que ocorre em territórios indígenas e pode ser fruto da organização das comunidades e associações indígenas quando estas constituem eventos locais e estes se tornam atrativos para outras comunidades indígenas brasileiras e estrangeiras e também para os turistas não-indígenas.

Estudou-se o território e o turismo como uma abordagem integrada e nos sentidos econômico, político, ambiental e cultural, o que permitiu visualizar que o histórico do turismo no território indígena Krahô ocorre desde o contato desta etnia com a sociedade envolvente.

No que se refere ao turismo no território indígena Krahô no sentido econômico, deve-se levar em consideração o aumento da renda das comunidades indígenas. Durante a realização do trabalho de campo, identificou-se que não se pode mencionar que existe uma renda anual definida como de origem do turismo. Os pequenos grupos de turistas que chegam até as aldeias Manoel Alves, Pedra Branca, Santa Cruz, Cachoeira e Kapey não negociam no sentido estritamente econômico. Estes grupos podem estar relacionados com as Instituições Públicas de Ensino Superior e com os órgãos do governo federal.

Aqui, defende-se a proposição de que os estudantes de graduação, os professores universitários e os pesquisadores, quando optam por desenvolver um trabalho de pesquisa e/ou de extensão num território indígena, podem querer participar de outras atividades que não as relacionadas ao desenvolvimento de determinado estudo, pois, em geral, espera-se um momento para praticar o lazer, o ócio e o entretenimento. Por isso pode-se afirmar que até mesmo entre esses visitantes há a prática do turismo nos diversos territórios indígenas. Além desses, grupos de turistas estrangeiros chegam à cidade de Itacajá (TO) e, em seguida, às 
aldeias. Nessa perspectiva, a organização do turismo no sentido econômico se define na elaboração de um plano de gestão para o turismo no território indígena Krahô, com o objetivo de identificar as possibilidades de aumentar a renda dos Krahô.

O turismo no território indígena Krahô no sentido político, por um lado, segue as regras impostas pela legislação ainda vigente, ou seja, o território ainda é identificado como área (terra) protegida e com fronteiras rígidas, e, por outro, com a organização das associações indígenas algumas conquistas foram obtidas. A busca constante da autonomia das populações indígenas está provocando transformações no sentido político do território. Assim, o turismo pode ser identificado de acordo com o sentido que o território expressa. Contudo, com as pressões internacionais para estender a universalização dos direitos humanos, as populações autóctones ao redor do mundo estão incluídas na pauta da igualdade dos direitos humanos. $\mathrm{O}$ que muda o sentido do território é que este deixa de ser considerado "território fechado" e recebe a nova atribuição de "território flexível". Seguindo esta lógica, o turismo como uma atividade econômica encontra nos territórios indígenas oportunidades para a sua expansão.

Já a análise do turismo no território indígena Krahô no sentido cultural pode ser considerada mais complexa, pois envolve a relação do turismo com as manifestações culturais das comunidades indígenas Krahô. Nesse sentido, deve-se considerar o calendário de rituais Krahô, envolvendo as duas metades sazonais que compõem a estrutura social Krahô. Pode-se afirmar que este calendário reúne um conjunto de diversos rituais, os quais são realizados no decorrer do ano.

As Feiras Krahô de Sementes Tradicionais permitem identificar a organização do turismo no território indígena Krahô. Além de ser um evento voltado para a celebração dos projetos aprovados e desenvolvidos, considera-se também como relevante do ponto de vista da elevação da auto-estima dos Krahô, tendo em vista, ainda, que a valorização cultural se expressa nos momentos de sociabilidade, de interação e de aproximação entre as populações indígenas de diferentes etnias e entre estas e as populações não-indígenas.

No que diz respeito ao turismo no território indígena Krahô no sentido ambiental, vale destacar que o território indígena Krahô constitui-se na maior área contínua de cerrados conservados do país. Em épocas em que as áreas de cerrados estão sendo incorporadas de forma desordenada ao cultivo de soja, milho, etc., a agricultura moderna e industrial mostrou a sua força ao ocupar a maioria expressiva das áreas de cerrados brasileiras. As áreas que restaram despertam bastante curiosidade do ponto de vista da pesquisa, da observação e do 
ecoturismo. Outro ponto que se deve destacar é a cosmologia Krahô, pois ela se reflete nos mitos e nas histórias antigas Krahô.

De uma maneira geral, o turismo no território indígena Krahô comporta um baixo fluxo de turistas, apenas em épocas de férias das Instituições de Ensino Superior. Os estudantes de graduação e pós-graduação procuraram chegar até as aldeias indígenas e à Kapey nos meses de janeiro, fevereiro e julho. Parece que os estudantes universitários utilizam suas férias para praticar o turismo e identificar possibilidades de desenvolver pesquisas abordando temáticas indígenas, ou apenas manter contato com as populações indígenas para confirmar o atual quadro social em que elas se encontram. As Feiras Krahô de Sementes oportunizam contatos culturais com diferentes populações indígenas e populações não-indígenas. De uma parte, alguns turistas participam e contribuem para a organização dos trabalhos e, de outra, considera-se os turistas que estão participando apenas para acompanhar a realização do evento, assim como com o intuito de assistir as manifestações culturais indígenas.

Portanto, o território indígena Krahô pode ser considerado um novo destino para o turismo em territórios indígenas, pois por intermédio da realização das Feiras Krahô demonstrou-se os fortes símbolos (imagens e objetos), os diversos significados, as manifestações culturais, a venda do artesanato, a elevação da auto-estima, a construção da identidade étnica e, por último, a interação cultural com as populações indígenas e nãoindígenas. 


\section{REFERÊNCIAS}

AB'SABER, A. N. Zoneamento ecológico e econômico da Amazônia; questões de escala e método. vol.3, n 5. São Paulo: IEA, 1989.

ANDRIOLO, A.; FAUSTINO, E. "Educação, turismo e cultura. A experiência de estudantes paulistas em Uruçanga.” In: RODRIGUES, A. B. (Org.). Turismo e desenvolvimento local. São Paulo: Hucitec, 1997.

ANSARAH, M. G. dos R. "Teoria geral do turismo.” In: ANSARAH, M. G. dos R. (Org.). Turismo. Como aprender, como ensinar 2. $2^{\mathrm{a}} \mathrm{ed}$. São Paulo: Editora SENAC São Paulo, 2001.

AOUN, S. "Paraíso à vista - os jardins do éden oferecidos pelo turismo." In: RODRIGUES, A. B. (Org.). Ecoturismo no Brasil: possibilidades e limites. São Paulo: Contexto, 2003.

AUleTE, C. Dicionário Contemporâneo da Língua Portuguesa. $5^{\mathrm{a}} \mathrm{ed}$. Rio de Janeiro: Editora Delta, 1970.

AZEVEDO, J. "Enraização" de propostas turísticas. In: RODRIGUES, A. B. (Org.). Turismo e desenvolvimento local. São Paulo: Hucitec, 1997.

BARIÉ, C. G. Pueblos indígenas y derechos constitucionales en América Latina: un panorama. $2^{\mathrm{a} e d . ~ B o l i v i a: ~ I n s t i t u t o ~ I n d i g e n i s t a ~ I n t e r a m e r i c a n o ~(M e ́ x i c o), ~ C o m i s i o ́ n ~ N a c i o n a l ~}$ para el Desarrollo de los Pueblos Indígenas (México) y Editorial Abya-Yala (Ecuador), 2003.

BARRETO, M. Turismo e legado cultural: as possibilidades do planejamento. Campinas: Papirus, 2000.

BENI, M. C. Análise do Desempenho Institucional do Turismo na Administração Pública. In: CASTROGIOVANI, A. C. (Org.). Turismo Urbano. São Paulo: Contexto, 2000.

A política do turismo. In: TRIGO, L. G. (Org.). Turismo. Como aprender, como ensinar. vol.1, 2 ed. São Paulo: Editora SENAC, 2001.

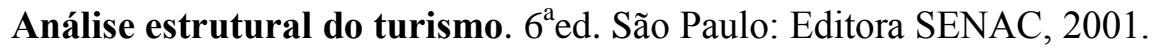

BHABHA, H. K. O local da cultura. Tradução de Myriam Ávila, Eliana Lourenço de Lima Reis e Gláucia Renate Gonçalves. Belo Horizonte: Editora UFMG, 1998.

BISSOLI, M. A. "Projetos turísticos.” In: ANSARAH, M. G. dos R. (Org.). Turismo. Como aprender, como ensinar 2. $2^{\mathrm{a}}$ ed. São Paulo: Editora SENAC São Paulo, 2001.

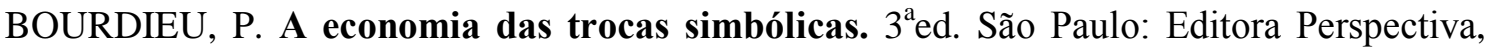
1992. 
Os usos sociais da ciência: por uma sociologia clínica do campo científico. Tradução de Denice Bárbara Catani. São Paulo: Editora UNESP, 2004.

BRANDÃO, C. R. et. al. O educador: vida e morte. $2^{a}$ ed. Rio de Janeiro: Edições Graal, 1982.

A educação como cultura. $17^{\mathrm{a}} \mathrm{ed}$. São Paulo: Editora Brasiliense, 1985.

(Org.). Pesquisa participante. $7^{\mathrm{a} e d .}$ São Paulo: Editora Brasiliense, 1988.

BRASIL. Constituição de 1998. Constituição da República Federativa do Brasil: texto constitucional promulgado em 5 de outubro de 1988, com as alterações adotadas pelas Emendas Constitucionais $n^{\circ} 1 / 92$ a 42/2003 e pelas Emendas Constitucionais de Revisão $n^{\circ} 1$ a 6/94. Brasília: Senado Federal, Subsecretaria de Edições Técnicas, 2004.

BRINGAS, R. N. L.; GONZÁLEZ, A. J. I. "El turismo alternativo como um elemento para el desarrollo sustentable de las comunidades indígenas: el caso de las etnias nativas de Baja California.” In: NIEVES, S. G. (Cood.). Desarrollo turístico y sustentabilidad. Zapopan, Jalisco: Universidad de Guadalajara, Centro Universitario de Ciencias Económico Administrativas, Departamento de Turismo, Recreación y Servicio, 2003.

CABREIRA, A. C.; MORETTI, E. C. Turismo Cultural na Reserva Indígena Francisco Horto Barbosa em Dourados - MS. Encontro de Geógrafos de América Latina X. São Paulo: Universidade de São Paulo, 2005.

CALVET, M. del C. M. H. Turismo e excursionismo rural: potencialidades, regulação e impactos. Londrina: Edições Humanidades, 2004.

CAPEL SAEZ, H. O Nascimento da Ciência Moderna e a América: O papel das comunidades científicas, dos profissionais e dos técnicos no estudo do território. Maringá: Eduem, 1999.

CAPRA, F. O ponto de mutação; a ciência, a sociedade e a cultura emergente. São Paulo: Editora Cultrix, 1982.

CARA, R. B. "El turismo y los procesos de transformacion territorial." In: RODRIGUES, A. B. (Org.). Turismo e Geografia: reflexões teóricas e enfoques regionais. $2^{\mathrm{a}}$ ed. São Paulo: Hucitec, 1999.

CARNEIRO, M. L. T. Os cristãos-novos e a questão da pureza de sangue: Alguns aspectos das manifestações racistas em Portugal e Brasil-Colônia do séc. XV ao XVIII. Dissertação (Mestrado), FFLCH, USP-SP, 1980.

CAZES, G. "Turismo e subdesenvolvimento: tendências recentes." In: RODRIGUES, A. B. (Org.). Turismo e Geografia: Reflexões teóricas e enfoques regionais. $2^{\text {a }}$ d. São Paulo: Hucitec, 1999.

CASTRO FARIA, L. Antropologia: escritos exumados. Espaços circunscritos: tempos soltos. Niterói: EdUFF, 1998. 
Antropologia: escritos exumados 2 - dimensões do conhecimento antropológico.

Niterói: EdUFF, 1999.

CASTRO, E. V. de. A inconstância da alma selvagem; e outros ensaios de antropologia. São Paulo: Cosac \& Naif, 2002.

CERTEAU, M. A invenção do cotidiano: a arte de fazer. Tradução de Ephrain Ferreira Alves. Petrópolis: Vozes, 1994.

CHAIN, M. M. Os aldeamentos indígenas e sua importância no povoamento da capitania de Goiás no século XVIII (1749-1811). Tese (Doutorado), FFLCH, USP-SP, 1972.

CHIARA, V. Folclore Krahó. Revista do Museu Paulista. N-S. vol.XIII. São Paulo, 1961.

A situação econômica e política dos índios Krahó estado de Goiás. Revista do Museu Paulista. Nova Série, vol.XXVI, São Paulo, 1979.

L'homme et l'espace chez les indiens Krahô Etat de Goias - Brasil. These (Doctorat), Paris, Ecole des Hautes Etudes en Sciences Sociales, 1981.

. "Parentesco Krahô: Espaço e dinâmica." In: REVISTA DO MUSEU PAULISTA. Nova Série, vol.XXIII, São Paulo, 1981/1982.

CLAVAL, P. “A geografia cultural: o estado da arte.” In: ROSENDAHL, Z.; CORREAA, R. L. Manifestações da cultura no espaço. Rio de Janeiro: EduERJ, 1999.

COELHO, M. C. N. "Natureza e discurso ecoturístico na Amazônia." In: REVISTA TERRITÓRIO. LAGET/UFRJ, ano III, nº 5, jul./dez. 1998.

COHEN, J. H. "Textile, tourism and community development." Annals of Tourism Research. vol.28, $\mathrm{n}^{\circ} 2,2001$.

CONFERÊNCIA DAS NAÇÕES UNIDAS SOBRE MEIO AMBIENTE E DESENVOLVIMENTO. Brasília: Câmara dos Deputados, Coordenação de Publicações, 1995.

CONTI, J. B. "Ecoturismo: Paisagem e Geografia." In: RODRIGUES, A. B. (Org.). Ecoturismo no Brasil: possibilidades e limites. São Paulo: Contexto, 2003.

. “A natureza nos caminhos do turismo.” In: RODRIGUES, A. B. (Org.). Turismo e Ambiente; reflexões e propostas. $2^{\text {a }}$ ed. São Paulo: Hucitec, 1999.

CONVENÇÃO Nº 169 DA OIT SOBRE POVOS INDIGENAS E TRIBAIS E RESOLUÇÃO REFERENTE À AÇÃO DA OIT SOBRE POVOS INDIGENAS E TRIBAIS. Brasília: OIT, 2004.

COSTA, W. M. da. Geografia Política e Geopolítica; discursos sobre o território e o poder. São Paulo: Editora Hucitec-Edusp, 1992. 
.O Estado e as políticas territoriais no Brasil. 10ªed. São Paulo: Contexto, 2001.

CORREAA, R. L. "Geografia cultural: passado e futuro - uma introdução.” In: ROSENDAHL, Z.; CORREAA, R. L. (Org.). Manifestações da cultura no espaço. Rio de Janeiro: EduERJ, 1999.

CUCHE, D. A noção de cultura nas ciências sociais. $2^{\mathrm{a}} \mathrm{ed}$. Tradução de Viviane Ribeiro. Bauru: EDUSC, 2002.

CUNHA, M. C. da (Org.). História dos índios do Brasil. São Paulo: Companhia das Letras, Secretaria Municipal de Cultura, FAPESP, 1992.

; ALMEIDA, M. W. B. "Populações tradicionais e conservação ambiental." In: CAPOBIANCO, J. P. R. et. al. (Orgs.). Biodiversidade na Amazônia Brasileira: Avaliação e ações prioritárias para a conservação, uso sustentável e repartição de benefícios. São Paulo: Estação Liberdade, Instituto Sócio-ambiental, 2001.

DÉBORD, G. A sociedade do espetáculo. Rio de Janeiro: Contraponto, 1997.

DUMAZIDIER, J. Sociologia empírica do lazer. $2^{\text {a } e d . ~ S a ̃ o ~ P a u l o: ~ P e r s p e c t i v a: S E S C, ~} 1999$.

Lazer e cultura popular. $3^{\mathrm{a}}$ ed. São Paulo: Editora Perspectiva, 2000.

EVANS-PRITCHARD, E. E. Os Nuer: Uma descrição do modo de subsistência e das instituições políticas de um povo nilota. $2^{\mathrm{a} e d}$. Tradução de Ana M. Goldberger Coelho. São Paulo: Editora Perspectiva, 2002.

FERNANDES, F. A função social da Guerra na sociedade tupinambá. $2^{\text {a }}$ ed. São Paulo: Livraria Pioneira Editora e Edusp, 1970.

FERREIRA, F. W. Planejamento Sim e Não: um modo de agir num mundo em permanente mudança. Rio de Janeiro: Paz e Terra, 1979.

FÓRUM CULTURAL MUNDIAL, PROGRAMAÇÃO SESC-BELENZINHO. 26 de junho a 04 de julho de 2004.

FOUREZ, G. A construção das ciências; introdução à filosofia e à ética das ciências. São Paulo: Editora da Universidade Estadual Paulista, 1995.

FROEHLICH, J. M. "Turismo Rural e Agricultura Familiar; explorando (criticamente) o cruzamento de abordagens e estratégias para o 'desenvolvimento'." In: ALMEIDA, J. A.; RIEDL, M. (Orgs.). Ecologia, lazer e desenvolvimento. São Paulo: EDUSC, 2000.

FURLAN, S. A. "Ecoturismo: do sujeito ecológico ao consumidor da natureza." In: RODRIGUES, A. B. (Org.). Ecoturismo no Brasil: possibilidades e limites. São Paulo: Contexto, 2003.

GEERTZ, C. A interpretação das culturas. Rio de Janeiro: Editora Guanabara Koogan, 1989. 
GOMES, P. C. da Costa. "A dimensão ontológica do território no debate da cidadania: O exemplo Canadense.’In: REVISTA TERRITÓRIO. LAGET/UFRJ, 1 (2), 1997.

"Cultura ou civilização: A renovação de um importante debate.” In: ROSENDAHL,

Z.; CORREAA, R. L. Manifestações da cultura no espaço. Rio de Janeiro: EduERJ, 1999.

GRÜNEWALD, R. de A. "Turismo e o 'resgate' da cultura Pataxó." In: BARRETO, M.; BANDUCCI JR., A. Turismo e identidade local: uma visão antropológica. Campinas-SP: Papirus, 2001.

GUERRA, E. F. Organização política e segurança alimentar na sociedade Krahô. Dissertação (Mestrado em Geografia), Uberlândia - MG, UFU, 2004.

GUIMARÃES, R. G. et. al. "Turismo em áreas indígenas." In: Encontro Nacional de Turismo com Base Local. Curitiba: Universidade Federal do Paraná e Centro Universitário Positivo, 2004.

HAESBAERT, R. Des-territorialização e identidade: A rede "gaúcha" no nordeste. Niterói: Eduff, 1997.

. "Identidades territoriais." In: ROSENDAHL, Z.; CORRÊA, R. L. (Orgs.). Manifestações da cultura no espaço. Rio de Janeiro: EduERJ, 1999.

O mito da desterritorialização: do "fim dos territórios" à multerritorialidade. Rio de Janeiro: Bertrand Brasil, 2004.

; RAMOS, T. T. "O mito da desterritorialização econômica.” In: GEOGRAPHIA: Revista da Pós-Graduação em Geografia. Departamento de Geografia, Universidade Federal Fluminense, Rio de Janeiro, Ano VI, nº12, Dezembro de 2004.

HARDT, M.; NEGRI, A. Império. Rio de Janeiro, São Paulo: Record, 2002.

HARVEY, D. A condição pós-moderna. São Paulo: Loyola, 2000.

HOBSBAWM, E.; RANGER, T. (Orgs.). A invenção das tradições. Rio de Janeiro: Paz e Terra, 1997.

IBAMA - Instituto Brasileiro do Meio Ambiente. Diretrizes de Pesquisa Aplicada ao Planejamento e Gestão Ambiental. Brasília, 1994.

KOHLHEPP, G. Conflitos de interesse no ordenamento territorial da Amazônia brasileira. vol.16, nº45. São Paulo: IEA, 2002.

KUHN, T. The structure of scientific revolutions. Chicago, University of Chicago, 1970 / São Paulo: Perspectiva, 1975.

JOUTARD, P. Esas vocês que nos llgam Del passado. Traducción de Nora Pasternac. México: Fondo de cultura econômica, s/d. 
JUNKER, B. H. A importância do trabalho de campo: Introdução às Ciências Sociais. Tradução de José Gurjão Neto. 1 ed. Rio de Janeiro: Editora Lidador, 1971.

JUNQUEIRA, C. Antropologia Indígena; uma introdução, história dos povos indígenas no Brasil. São Paulo: EDUC, 2002.

KNAFOU, R. "Turismo e território: Por uma abordagem científica do turismo." In: RODRIGUES, A . B. (Org.). Turismo e Geografia: reflexões teóricas e enfoques regionais. $2^{\mathrm{a} e d . ~ S a ̃ o ~ P a u l o: ~ H u c i t e c, ~} 1999$.

LEI No 6.001 - De 19 de Dezembro de 1973 - Dispõe sobre O Estatuto do Índio.

LEVIS-STRAUSS, C. "Raça e História.” In: COMAS, J. et. al. (Org.). Raça e Ciência I. São Paulo: Editora Perspectiva, 1970.

O pensamento selvagem. Tradução de Tânia Pelegrini. Campinas: Papirus, 1989.

. Mitologicas: Lo crudo y lo cocido I. Quinta reimpresión. México: Fondo de Cultura Econômica (Sección de Obras de Antropologia), 1996.

Mitológicas II: De la miel a las cenizas. Quarta reimpresión. México: Fondo de Cultura Econômica (Sección de Obras de Antropologia), 2002.

LIMA, M. L. C. “(Eco)turismo em Unidades de Conservação.” In: RODRIGUES, A. B. (Org.). Ecoturismo no Brasil: possibilidades e limites. São Paulo: Contexto, 2003.

LÜDKE, M. M. E. A. A. Pesquisa em educação: abordagens qualitativas. São Paulo: EPU, 1986.

MACHADO, L. O. Mitos e realidades da Amazônia brasileira no contexto geopolítico internacional (1540-1912). Tese (Doutorado), Barcelona, Universitat de Barcelona, 1989.

MALINOWSKI, B. Um diário no sentido estrito do termo. Tradução de Celina Cavalcante Falck. Rio de Janeiro: Record, 1997.

MANUAL INDÍGENA DE ECOTURISMO. Brasília: MMA, 1997.

MARIANI, M. A. P. "Relações mediadas pela atividade turística - considerações sobre Bonito (MS)." In: RODRIGUES, A. B. (Org.). Ecoturismo no Brasil: possibilidades e limites. São Paulo: Contexto, 2003.

MEIHY, J. C. S. B. Manual de História Oral. 4ªed. São Paulo: Edições Loyola, 2002.

MELATTI, J. C. O sistema social Krahô. Tese (Doutorado), FFLCH, USP, 1970.

O messianismo Krahô. São Paulo: Herder, 1972.

Ritos de uma tribo Timbira. São Paulo: Ática, 1978. 
MORAES, A. C. R. Bases da formação territorial do Brasil: o território colonial brasileiro no "longo" século XVI. São Paulo: Hucitec, 2000.

MOTA, L. T. "As guerras de conquistas nos territórios indígenas Kaingang, Xokleng, Xetá e Guarani.” In: MOTA, L. T. (Org.). As cidades e os povos indígenas: mitologias e visões. Maringá: EDUEM, 2000.

ODUM, E. Ecologia. Rio de Janeiro: Editora Guanabara Koogan, 1983.

OLIVEIRA, A. U. A fronteira Amazônica Mato-Grossense: Grilagem, corrupção e violência. Tese (Livre Docência), FFLCH, USP-SP, 1997.

OLIVEIRA, R. C. de. Urbanização e tribalismo; a integração dos índios Terena numa sociedade de classes. Rio de Janeiro: Zahar Editores, 1968.

. "A Categoria de (des) ordem e a pós-modernidade da Antropologia." In:

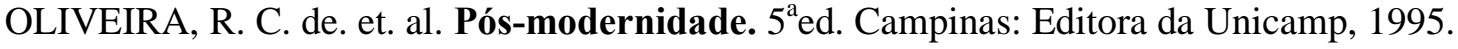

O trabalho do antropólogo. $2^{\mathrm{a}}$ ed. Brasília: Paralelo 15, Editora da UNESP, 2000.

ORTIZ, R. A moderna tradição brasileira. 5ªed. São Paulo: Brasiliense, 2001.

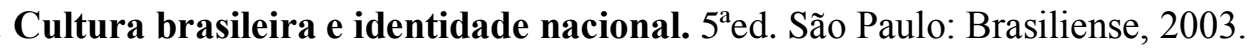

. Mundialização e cultura. 1ªed. São Paulo: Brasiliense, 2003.

PELEGRINI FILHO, A. Ecologia, Cultura e Turismo. Campinas: Papirus, 1993.

PIRES, P. dos S. "Interfaces ambientais do turismo.” In: TRIGO, L. G. (Org.). Turismo. Como aprender, como ensinar. vol.1, 2 ed. São Paulo: Editora SENAC, 2001.

PORTUGUEZ, A. P. "Elementos para uma abordagem crítica do turismo no ensino de primeiro e segundo graus." In: RODRIGUES, A. B. (Org.). Turismo e desenvolvimento local. São Paulo: Hucitec, 1997.

RAVAGNANI, O. M. "Os últimos aldeamentos indígenas da Província de Goiás." In: REVISTA DO MUSEU PAULISTA. Nova Série. Vol.XXII, São Paulo, 1987.

RIBEIRO, B. G. “Os estudos de cultura material: propósitos e métodos.”In: REVISTA DO MUSEU PAULISTA. Nova Série. Vol.XXX, São Paulo, 1985.

ROCHA, G. O. R. da. "Ecoturismo na Amazônia: uma análise das políticas públicas planejadas pela Sudam.” In: RODRIGUES, A. B. (Org.). Turismo e Ambiente; reflexões e propostas. $2^{\text {a }}$ d. São Paulo: Hucitec, 1999.

RODRIGUES, A. B. “Turismo Local: oportunidades para inserção.” In: RODRIGUES, A. B. (Org.). Turismo e desenvolvimento local. São Paulo: Hucitec, 1997. 
"Desafios para os estudiosos do turismo." In: RODRIGUES, A. B. (Org.). Turismo e Geografia: reflexões teóricas e enfoques regionais. $2^{\mathrm{a}}$ ed. São Paulo: Hucitec, 1999.

"Turismo Rural no Brasil - ensaio de uma tipologia." In: RODRIGUES, A. B. (Org.). Turismo Rural: práticas e perspectivas. São Paulo: Contexto, 2001.

Hucitec, 2001.

Turismo e espaço: rumo a um conhecimento transdisciplinar. $3^{\mathrm{a}}$ ed. São Paulo:

. "Geografia do turismo: novos desafios." In: TRIGO, L. G. (Org.). Turismo. Como aprender, como ensinar. vol.1, $2^{\mathrm{a}}$ ed. São Paulo: Editora SENAC, 2001.

"Ecoturismo - limites do eco e da ética." In: RODRIGUES, A. B. (Org.). Ecoturismo no Brasil: possibilidades e limites. São Paulo: Contexto, 2003.

"Patrimônio, território e empreendedorismo: pilares do desenvolvimento com base local.” In: REVISTA APORTES Y TRANSFERENCIAS. Mar Del Plata-Argentina, $\mathrm{n}^{\circ}$ 7, vol.2, 2003.

RODRIGUES, A. M. "Desenvolvimento sustentável e atividade turística." In: RODRIGUES, A. B. (Org.). Turismo e desenvolvimento local. São Paulo: Hucitec, 1997.

RODRIGUES, C. L. Limites do consenso: territórios polissêmicos na Mata Atlântica e a gestão ambiental participativa. Tese (Doutorado), FFLCH, USP-SP, 2001.

"Na safra do turismo." In: RODRIGUES, A. B. (Org.). Ecoturismo no Brasil: possibilidades e limites. São Paulo: Contexto, 2003.

RODRIGUES, M. N. "Índios querem o fim da tutela da Funai.” In: JORNAL BRASIL DE FATO. São Paulo, 31 de março a 06 de abril de 2005.

RUSCHMAnN, D. V. de M. Turismo e Planejamento Sustentável. Campinas: Papirus, 1997.

"Planejamento turístico." In: A . M. G. dos R. (Org.).Turismo. Como aprender, como ensinar. vol.2, $2^{\mathrm{a}}$ ed. São Paulo: Editora do SENAC, 2001.

RYAN, C.; HUYTON, J. “Tourism and aboriginal people.”In: Annais of Tourism Research. vol.29, n⿳⺈, 2002.

SALVATI, S. S. (Org.). Turismo responsável - Manual para políticas públicas. Brasília: WWF Brasil, 2004.

SANTILLI, P. "Ciência, verdade, justiça." In: GRUPIONI, L. D. B.; VIDAL, L. B.; FISCHMAN, R. (Orgs.). Povos indígenas e tolerância: Construindo práticas de respeito e solidariedade. São Paulo: Edusp, 2001.

SANTOS, B. de S. Um discurso sobre as ciências na transição para uma ciência pósmoderna. vol.2, n² 2. São Paulo: EDUSP, Estudos Avançados, maio/agosto 1988. 
Introdução a uma ciência pós-moderna. Rio de Janeiro: Graal, 1989.

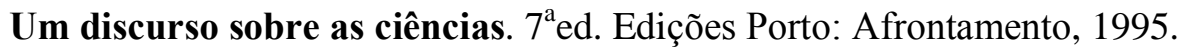

SANTOS, M. Por uma Geografia Nova: da crítica da Geografia a uma Geografia crítica. São Paulo: Hucitec, 1986.

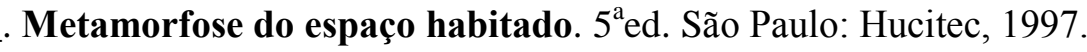

Por uma Outra Globalização: do pensamento único à consciência universal. Rio de Janeiro: Editora Record, 2001.

; SILVEIRA, M. L. (Orgs.). O Brasil: território e sociedade no início do século XXI. Rio de Janeiro: Record, 2001.

A natureza do espaço. Técnica e tempo; razão e emoção. São Paulo: Editora da Universidade de São Paulo, 2002.

2002.

A Natureza do Espaço: Técnica e Tempo, Razão e Emoção. São Paulo: Edusp,

“O retorno do território.” In: SANTOS, M. et al. (Orgs.). Território, Globalização

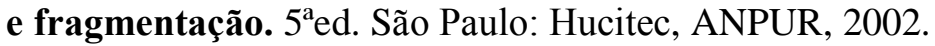

SCHETTINO, M. P. F. A questão fundiária indígena, o indigenismo e o novo governo. Disponível em: www.funai.gov.br/ultimas/Crevista/artigos/novo. Consultado em 18/10/2005.

SCHULTZ, H. "Lendas dos Índios Krahô.” In: REVISTA DO MUSEU PAULISTA. N.S., vol.IV. São Paulo: Museu Paulista, 1950.

SEABRA, O.; CARVALHO, M. de; LEITE, J. C. Território e Sociedade: Entrevista com

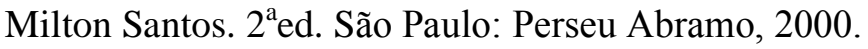

SERRANO, C. M. de T. "O "produto" ecoturístico.” In: ANSARAH, M. G. dos R. (Org.). Turismo. Como aprender, como ensinar 2. $2^{\mathrm{a}} \mathrm{ed}$. São Paulo: Editora SENAC São Paulo, 2001.

SILVA, A. L. da. "A educação indígena entre diálogos interculturais e multidisciplinares: Introdução.” In: SILVA, A . L. da; FERREIRA, M. K. L. (Orgs.). Antropologia, história e educação: a questão indígena e a escola. $2^{\mathrm{a}} \mathrm{ed}$. São Paulo: Global, 2001.

. Uma "Antropologia da educação" no Brasil? Reflexões a partir da escolarização indígena. In: SILVA, A. L. da; FERREIRA, M. K. L. (Orgs.). Antropologia, história e educação: a questão indígena e a escola. $2^{\mathrm{a}} \mathrm{ed}$. São Paulo: Global, 2001.

Uma "Antropologia da educação" no Brasil? Reflexões a partir da escolarização indígena. In: SILVA, A. L. da; FERREIRA, M. K. L. (Orgs.). Antropologia, história e educação: a questão indígena e a escola. $2^{\mathrm{a}} \mathrm{ed}$. São Paulo: Global, 2001. 
SILVA, M. O. da Silva e. Refletindo a pesquisa participante no Brasil e na América Latina. São Paulo: Cortez, 1986.

SILVEIRA, M. L. "Da fetichização dos lugares à produção local do turismo." In: RODRIGUES, A. B. (Org.). Turismo. Modernidade. Globalização. $2^{\mathrm{a} e d . ~ S a ̃ o ~ P a u l o: ~}$ Hucitec, 1999.

"Totalidade e fragmentação: o espaço global, o lugar e a questão metodológica, um exemplo argentino.” In: SANTOS, M. et. al. (Orgs.). Fim de século e globalização. $4^{\mathrm{a}}$ ed. São Paulo: Hucitec, ANPUR, 2002.

SILVEIRA, M. A. T. da. "Planejamento territorial e dinâmica local: bases para o turismo sustentável.” In: RODRIGUES, A. B. (Org.). Turismo e desenvolvimento local. São Paulo: Hucitec, 1997.

“Ecoturismo, políticas públicas e a estratégia paranaense." In: RODRIGUES, A. B. (Org.). Ecoturismo no Brasil: possibilidades e limites. São Paulo: Contexto, 2003.

SONEIRO, J. C. Aproximacion a la geografia Del turismo. Madrid: Editorial Sintesis, 1991.

SOUZA, M. J. L. de. Planejamento integrado de desenvolvimento natureza, validade e limites. São Paulo: Terra Livre - AGB, nº10, janeiro-julho de 1992.

"O território: sobre espaço e poder, autonomia e desenvolvimento." In: CASTRO, I. E. de; GOMES, P. C. da C.; CORREIA, R. L. (Orgs.). Geografia: Conceitos e Temas. Rio de Janeiro: Bertrand Brasil, 1995.

A teorização sobre o desenvolvimento em uma época de fadiga teórica, ou: sobre a necessidade de uma "teoria aberta" do desenvolvimento sócio-espacial. In: REVISTA TERRITÓRIO. 1(1), LAGET, UFRJ, Jul./Dez. de 1996.

. "Como pode o turismo contribuir para o desenvolvimento local?" In: RODRIGUES, A. B. (Org.). Turismo e desenvolvimento local. São Paulo: Hucitec, 1997.

A expulsão do paraíso. O "paradigma da complexidade" e o desenvolvimento sócioespacial. In: CASTRO, I. E. de; GOMES, P. C. da C.; CORREIA, R. L. (Orgs.). Explorações Geográficas: Percursos no fim do século. Rio de Janeiro: Bertrand Brasil, 1997.

TALAVERA, A .S. O Rural como Produto Turístico: algo de novo brilha sob o sol? In: SERRANO,C.; BRUHNS; H. T.; LUCHIARI, M.T. D. P. (Orgs.). Olhares contemporâneos sobre o turismo. Campinas, Papirus, 2000 (Coleção Turismo). p. 151-170.

TASSINARI, A. M. I. "Sociedades indígenas: Introdução ao tema da diversidade cultural." In: SILVA, A. L. da; GRUPIONI, L. D. B. (Orgs.). A temática indígena na escola: novos subsídios para professores de $\mathbf{1}^{\mathbf{0}} \mathbf{e} \mathbf{2}^{\mathbf{0}}$ graus. Brasília: MEC/MARI/UNESCO, 1995.

THIOLLENT, M. J. L. Crítica metodológica, investigação social e enquête operária. São Paulo: Livraria e Editora Polis, 1982. 
Metodologia da pesquisa-ação. $5^{\text {a }}$ d. São Paulo: Cortez, 1992.

THOMPSON, P. A voz do passado: história oral. Tradução de Lólia Lourenço de Oliveira. Rio de Janeiro: Paz e Terra, 1992.

TOCANTINS (ESTADO). Secretaria do Planejamento e Meio Ambiente. Atlas do Tocantins: Subsídios ao planejamento da gestão territorial. Palmas: SEPLAN, Diretoria de Zoneamento Ecológico-Econômico - DEZ-Planos: SEPLAN, 1999.

TRIGO, L. G. G. “O Turismo no Espaço Globalizado.” In: RODRIGUES, A. B. (Org.). Turismo, Modernidade e Globalização. São Paulo: Hucitec, 1999.

. Turismo e Civilização: mergulhando nos berços da humanidade. São Paulo: Contexto, 2001.

. "As possibilidades da filosofia." In: TRIGO, L. G. (Org.). Turismo. Como aprender, como ensinar. vol.1, 2ªed. São Paulo: Editora SENAC, 2001.

USP-SP, 2003.

Entretenimento: Uma Análise cultural e econômica. Tese (Livre Docência), ECA,

UNIVERSIDADE FEDERAL DO PARANÁ. Sistemas de Bibliotecas - Citações e notas de rodapé. Curitiba: Ed. da UFPR, 2000.

\section{SITES}

www.amazolink.org/encontro_indigena/index.html. Consultado em 20/10/2005.

www.atlanticanews.com.br/notícias/jogos_indios_ps.htm. Consultado em 13/10/2005.

www.cdi.gob.mx.conadepi/iii/cletus/index.html. Consultado em 18/10/2005.

www.culturabrasil.pro.br/cartadaterra.htm. Consultado em 14/10/2005.

www.ecologica.org.br/eco/ececo_nuc.htm. Consultado em 29/01/2002.

www.encuentroindigena.cl/ensayos/etnotur.htm. Consultado em 10/01/2004.

www.embratur.gov/economia/introdução.asp. Consultado em 20/12/2002.

www.embratur.gov.br/br/kaiapo/ver.asp?conteúdo=2186\&id=. Consultado em 10/09/2004.

www.funai.gov.br/indios/jogos/1o_jogos/1_jogos.htm. Consultado em 07/10/2005.

www.funai.gov.br/indios/jogos/2o_jogos/2_jogos.htm. Consultado em 07/10/2005.

www.funai.gov.br/indios/jogos/3o_jogos/3_jogos.htm. Consultado em 07/10/2005. 
www.funai.gov.br/ultimas notícias/2 semestre 2003. Consultado em 07/10/2005. www.funai.gov.br/ultimas/noticias/2_semestre_2003. Consultado em 07/10/2005. www.funai.gov.br/ultimas/1_revista/artigos/novd. Consultado em 18/10/2005. www.kraho.org.br. Consultado em 10/01/2004. www.planejamento.gov.br/planejamento_investimento/conteúdo/notícias. Consultado em 13/10/2005.

www.prodigyweb.net.mx/iqcdir/SalaPrensa/siete.htm. Consultado em 03/10/2005. www.puconturismo.cl/etnico/index.htm. Consultado em 21/10/2005. www.rumbo.com.br/guide/america/chile/sitio1.htm. Consultado em 20/10/2005. www.rehue.csociales.uchile.cl/identidades/art. Consultado em 21/10/2005. www.socioambiental.org/pib/epi/pontyguara/index.htm. Consultado 21/10/2005 www.survival.es. Consultado em 10/07/2005

www.ubatuba.gov.br. Consultado em 04/10/2005 www.2.uol.com.br/campogrande/temmais/jogosindigenas. Consultado em 13/10/2005. www.uol.com.br/ambiental/site/artigos/ultnot/ultnot864u9.shl. Consultado em 20/204/2002. www.vasp.com.br/paisagens/tocantins.html. Consultado em 29/02/2002. 
ANEXOS 


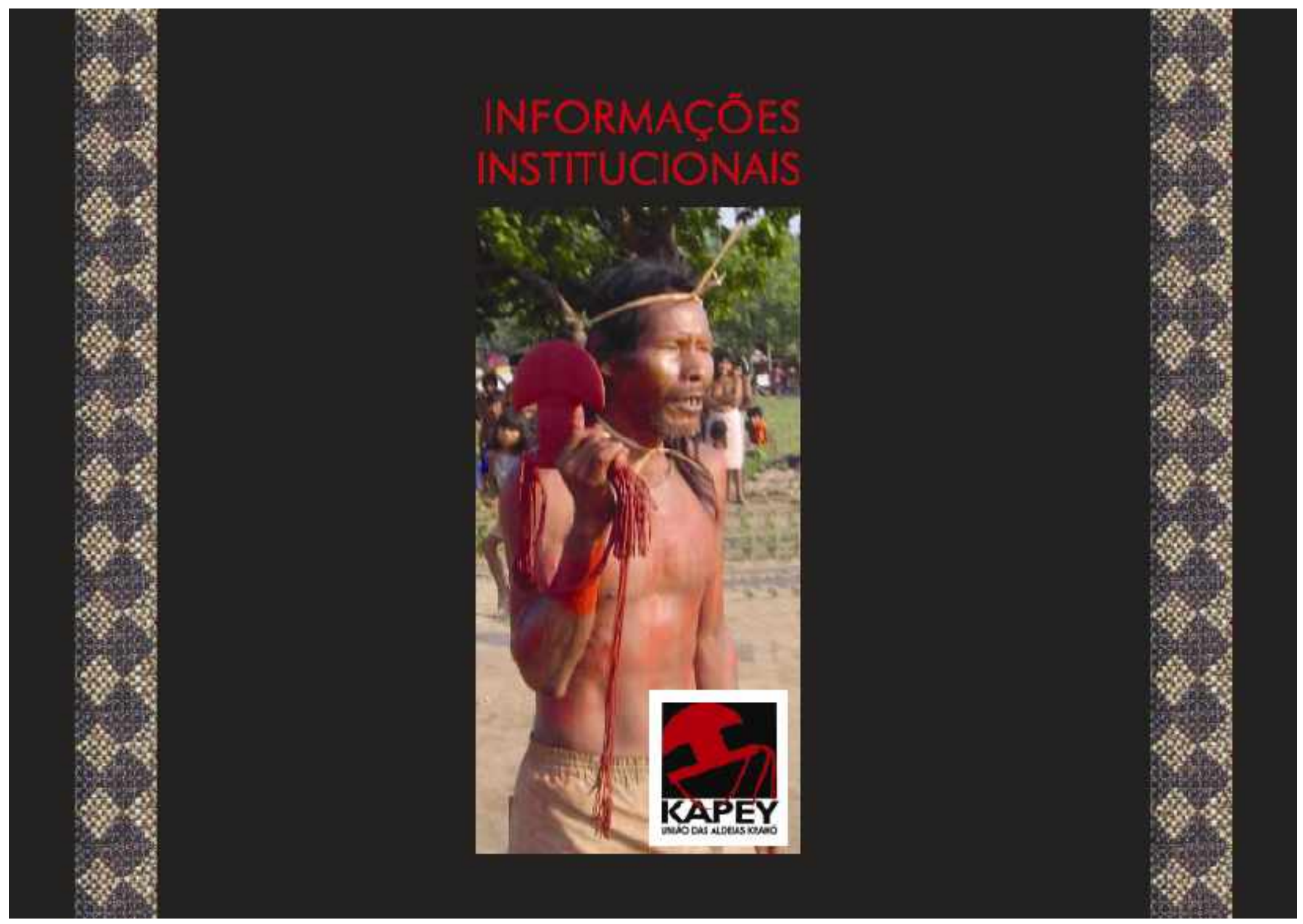




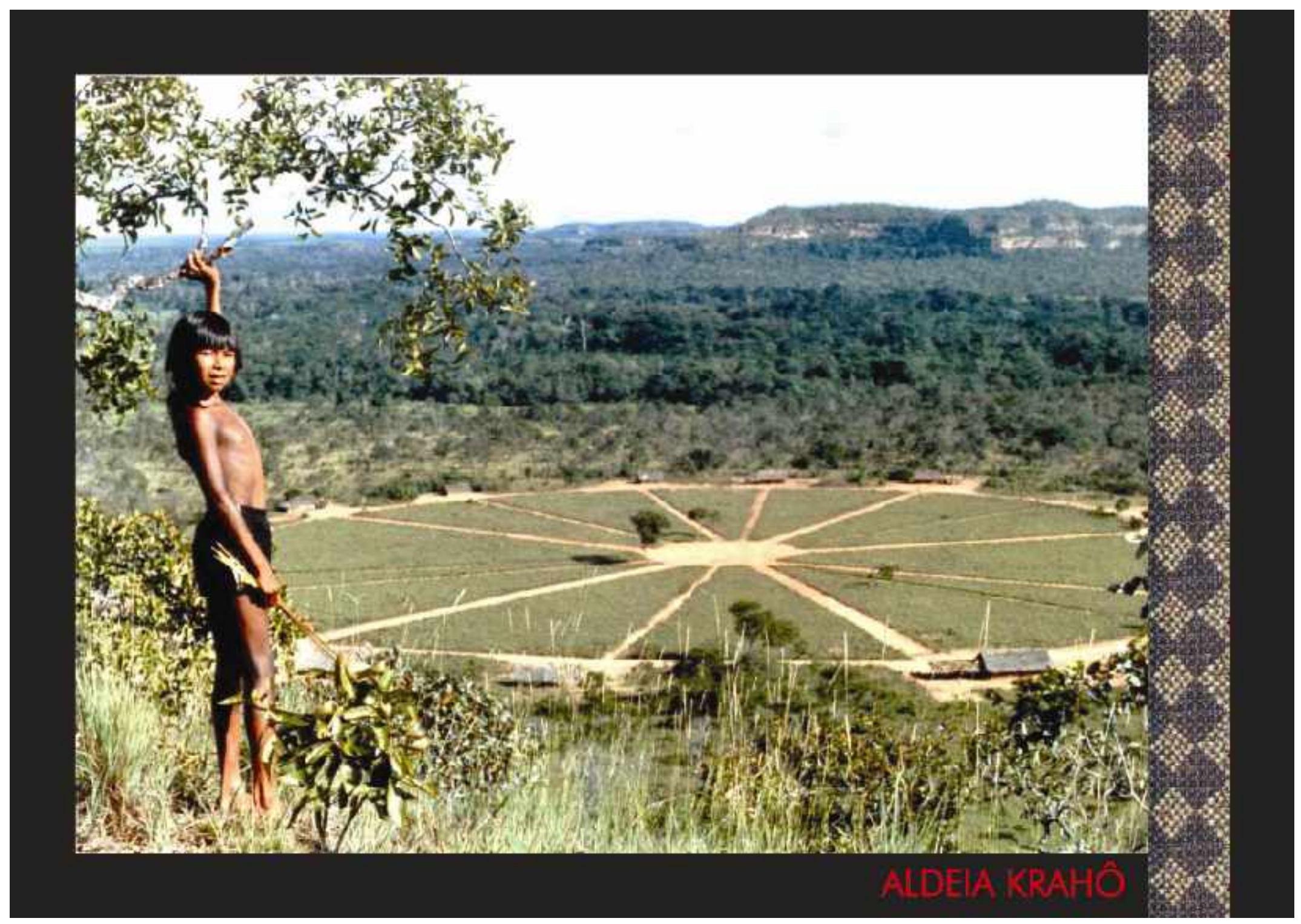




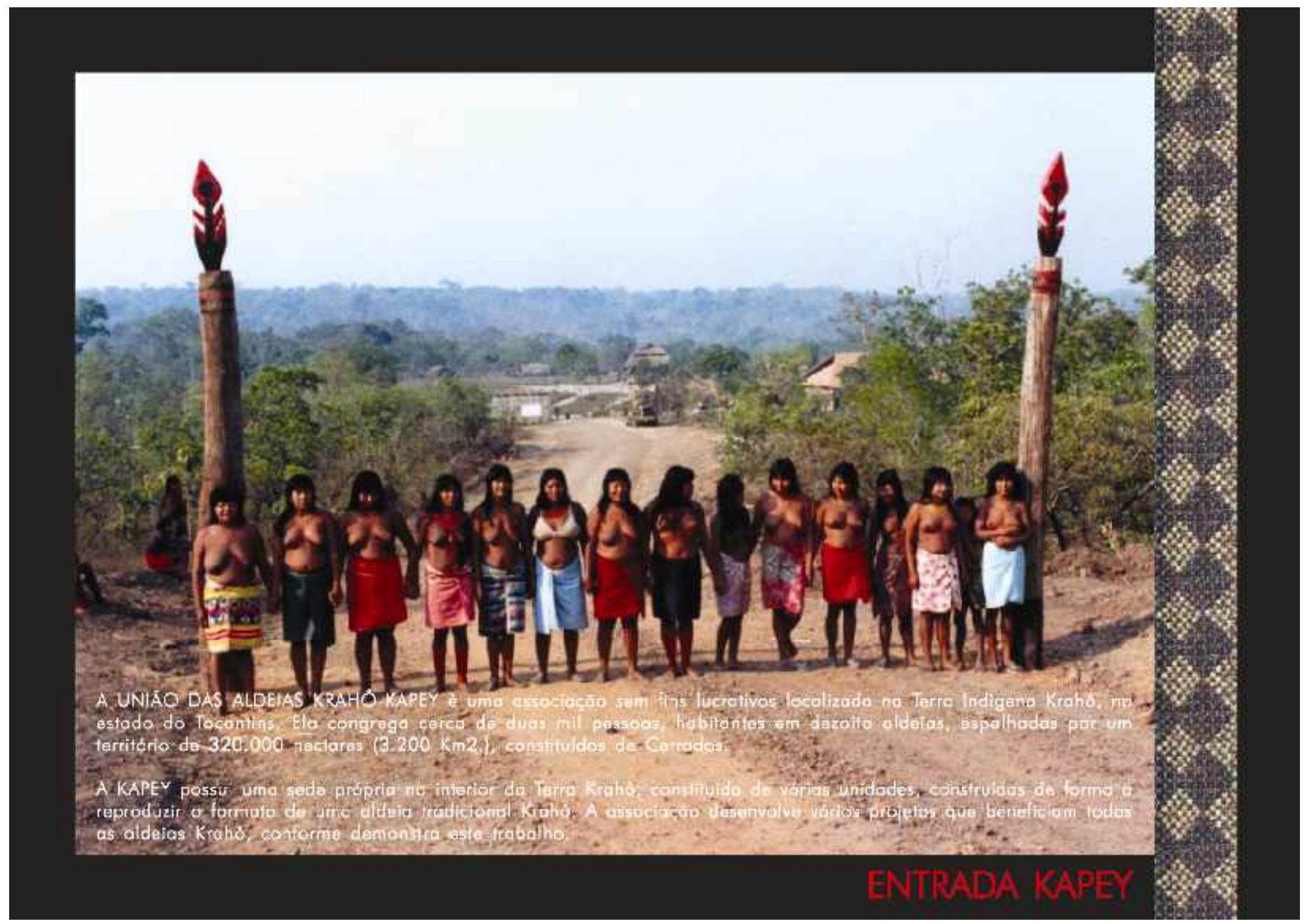




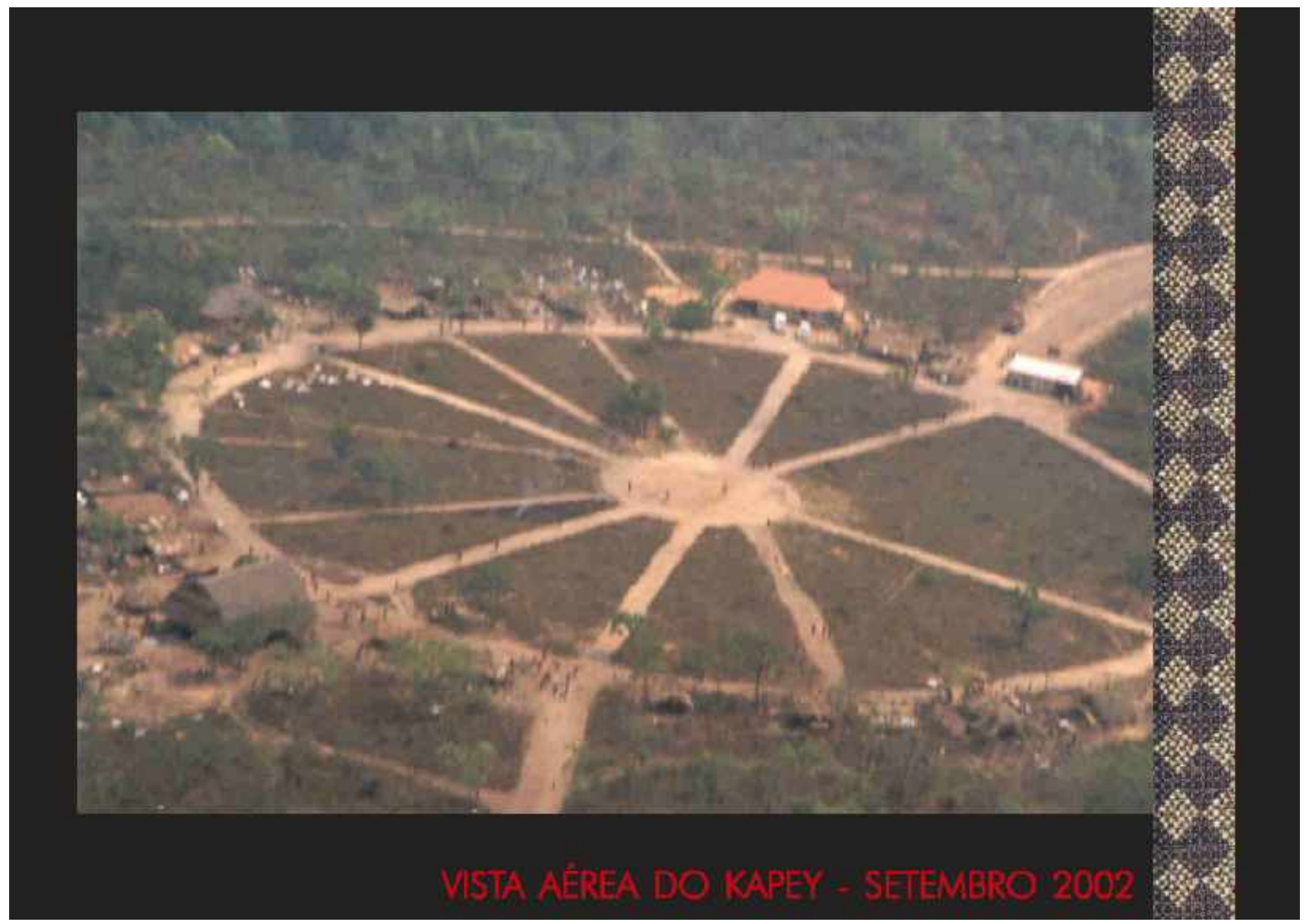




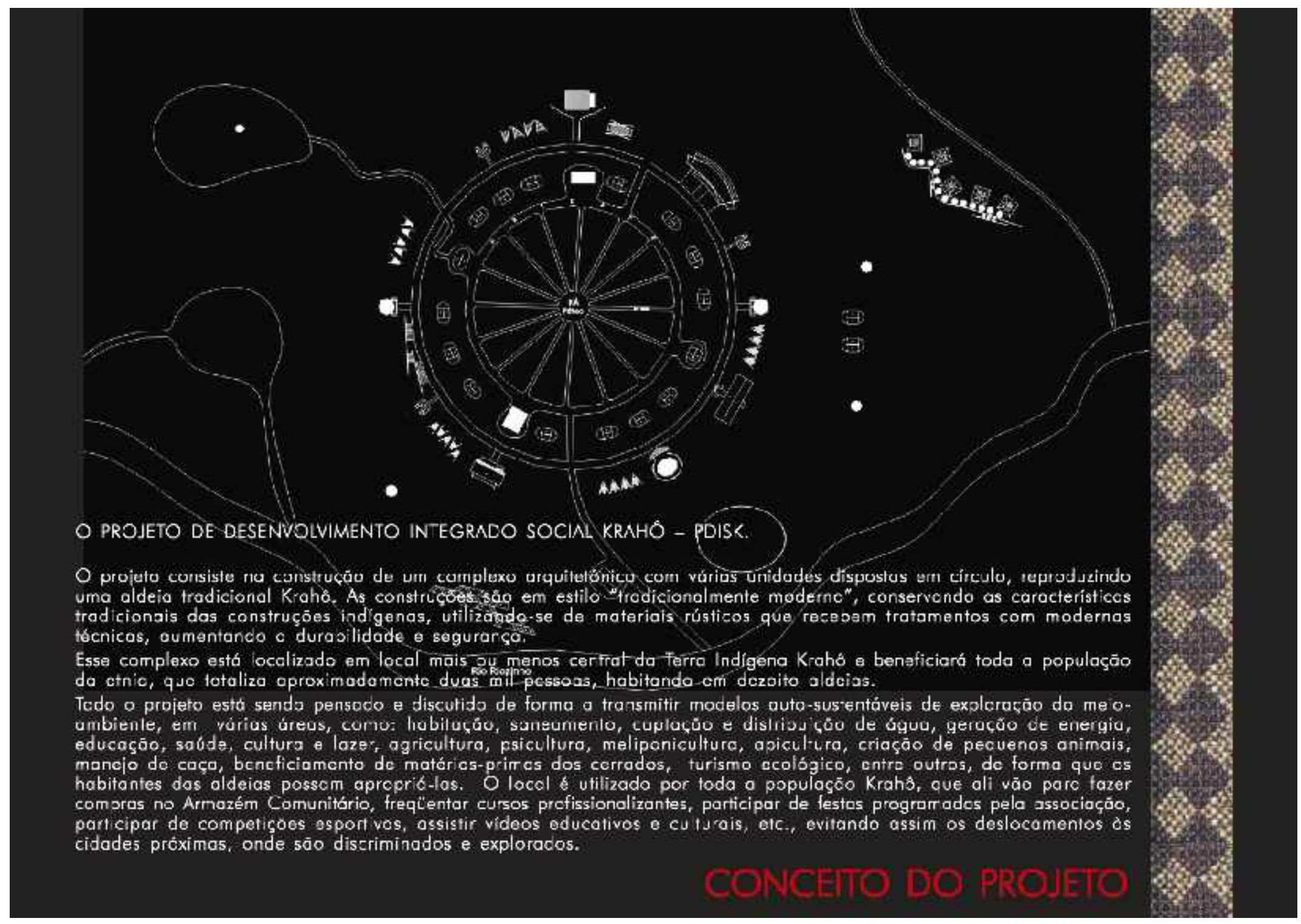




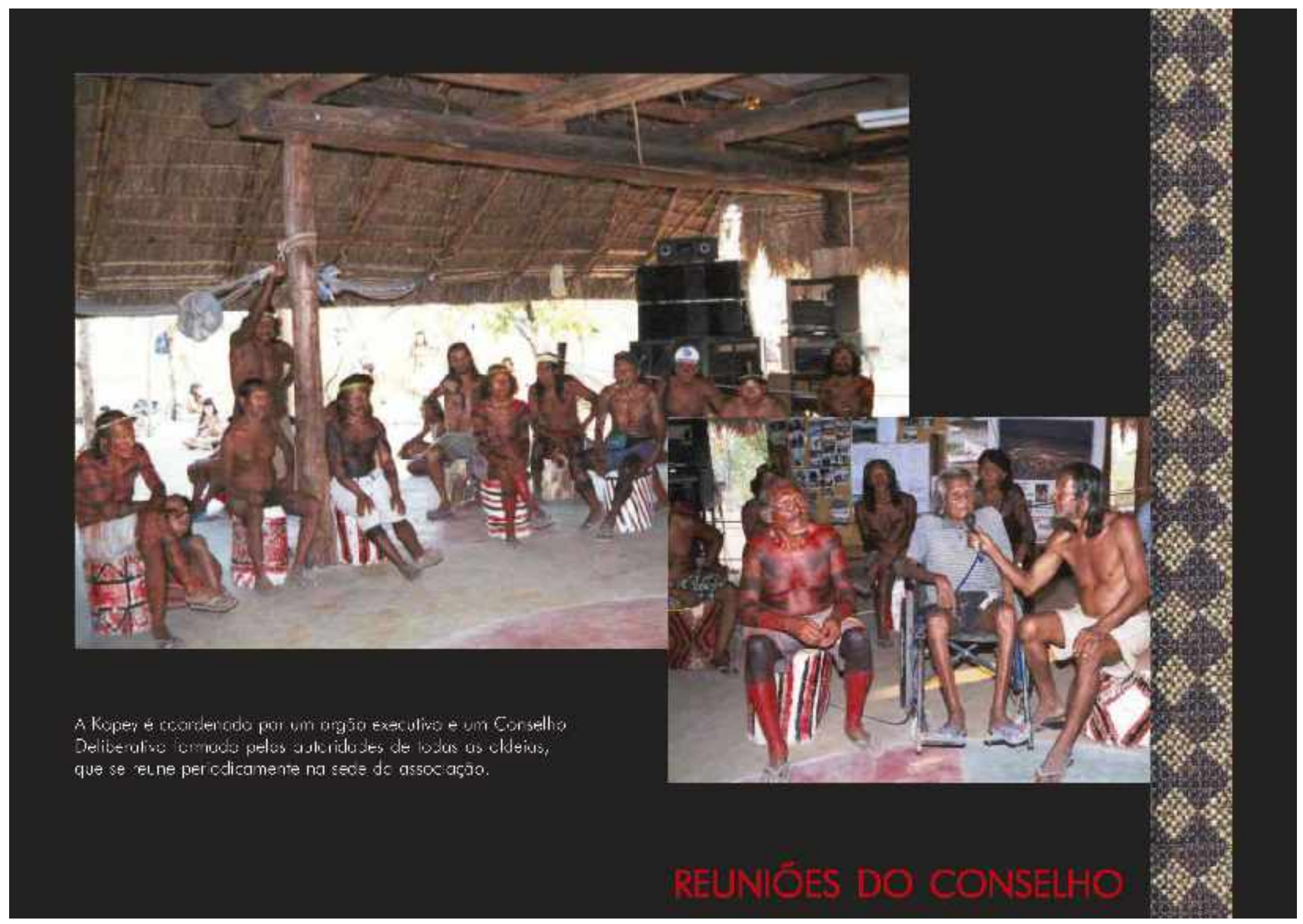



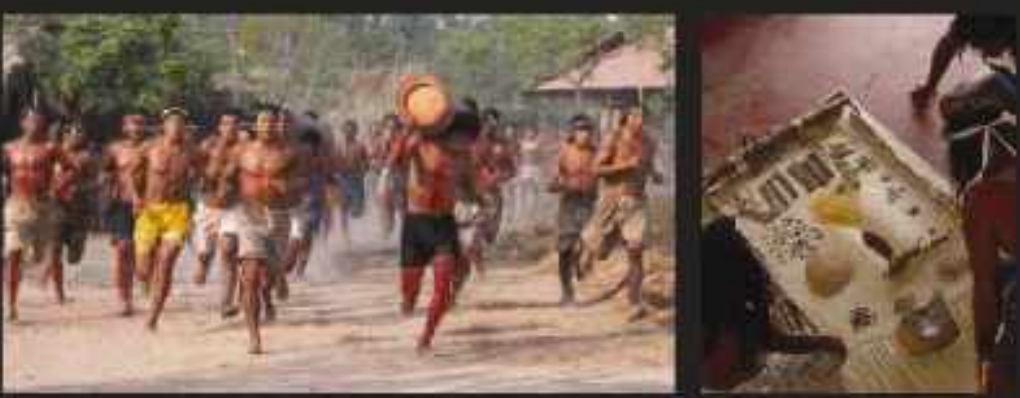

Va sede da Kopcy sco realizases inimieros exentos, cemo creonius cursos, festes Iredicionais af lig ices.

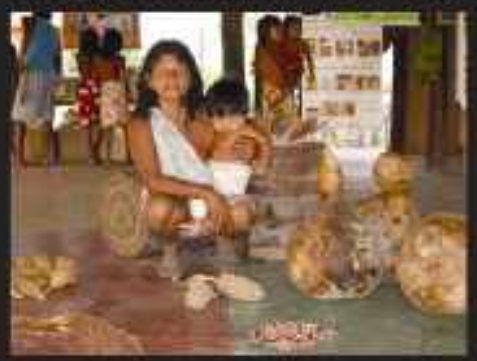

II: 군

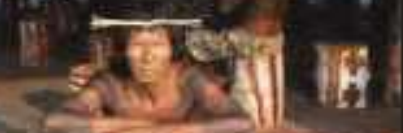

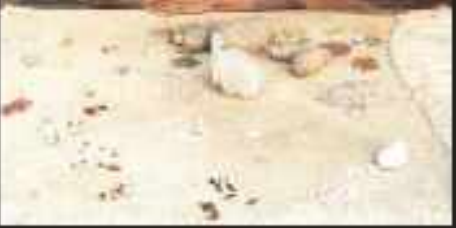

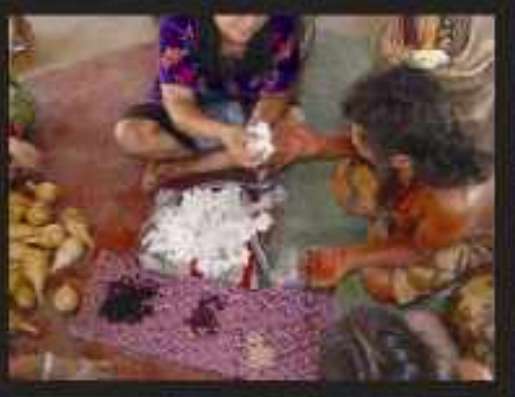

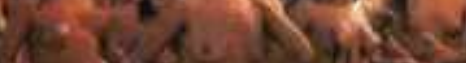

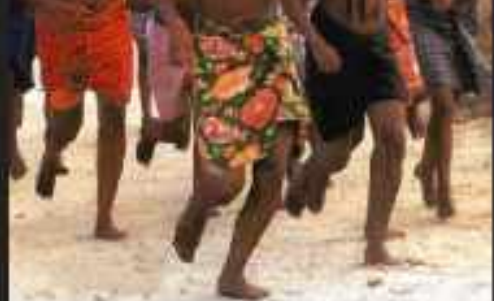

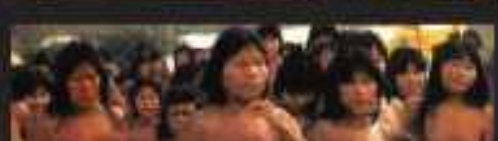

$5^{a}$ Feira Krigh

Sementes Trdallieinais.

- Troca de sementes indiguras, - Palestrass.

- Olicinas técnicas:

- Exposigoes:

- Bebates sobre Agriculitura e Alimentacha:

- Artesanato

o. Rituais indigenas:

DE 24 A 29 DE SETEMBBRO/2002

erra Indigena Krahio - Macaiat to

Estado do Tocantino-BRASIL.

1) Abertura ao PUELICO soment

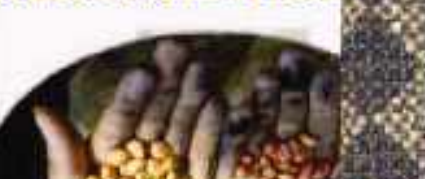

19:
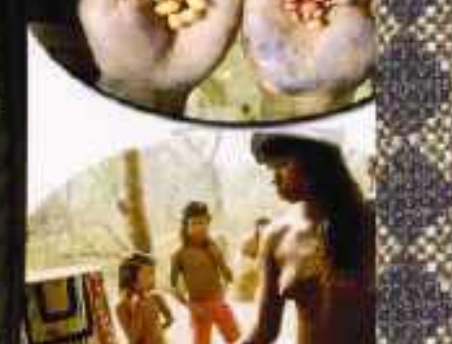

(2.
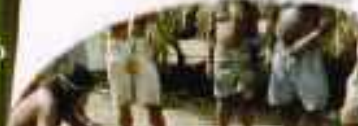

.

.

.

国 $x=$

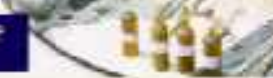

(2) 


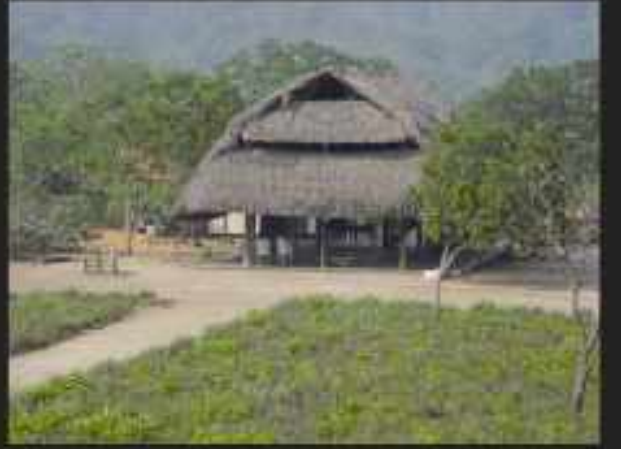

A Eseala Caxek axi lem por abjelivo diund un rogus a inoder ios lecinicus de pricduras ugricols. cuitudos som io meic combiente,

aproveromento dos alimentos, ares e ofic cs

e creservacao da clitura krato Elo arende

joveins coses kreho e fuls ona ro sisema

mat iler, rom cursos intensions tegunnes na

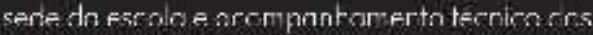

dunos an suos at virados nos o deios.

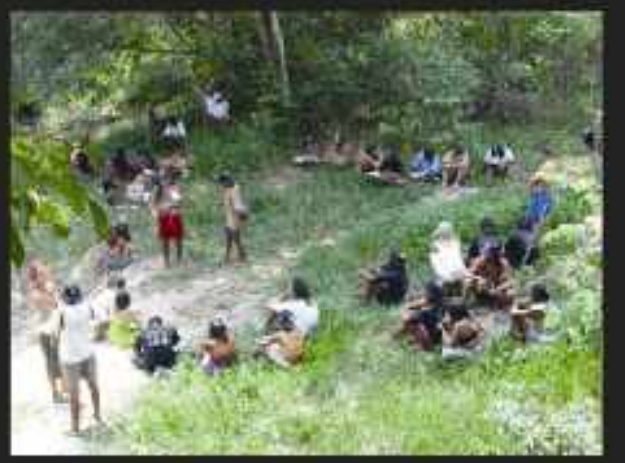

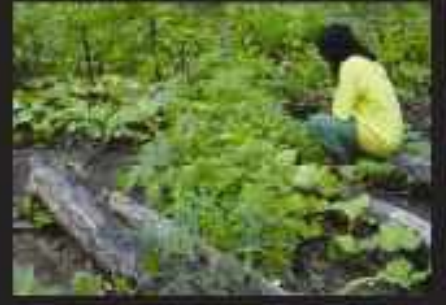

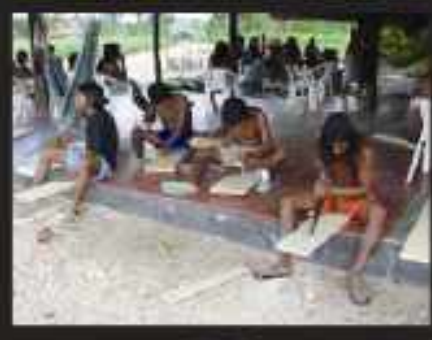

(3) 0 (x)

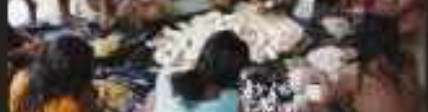

(x)
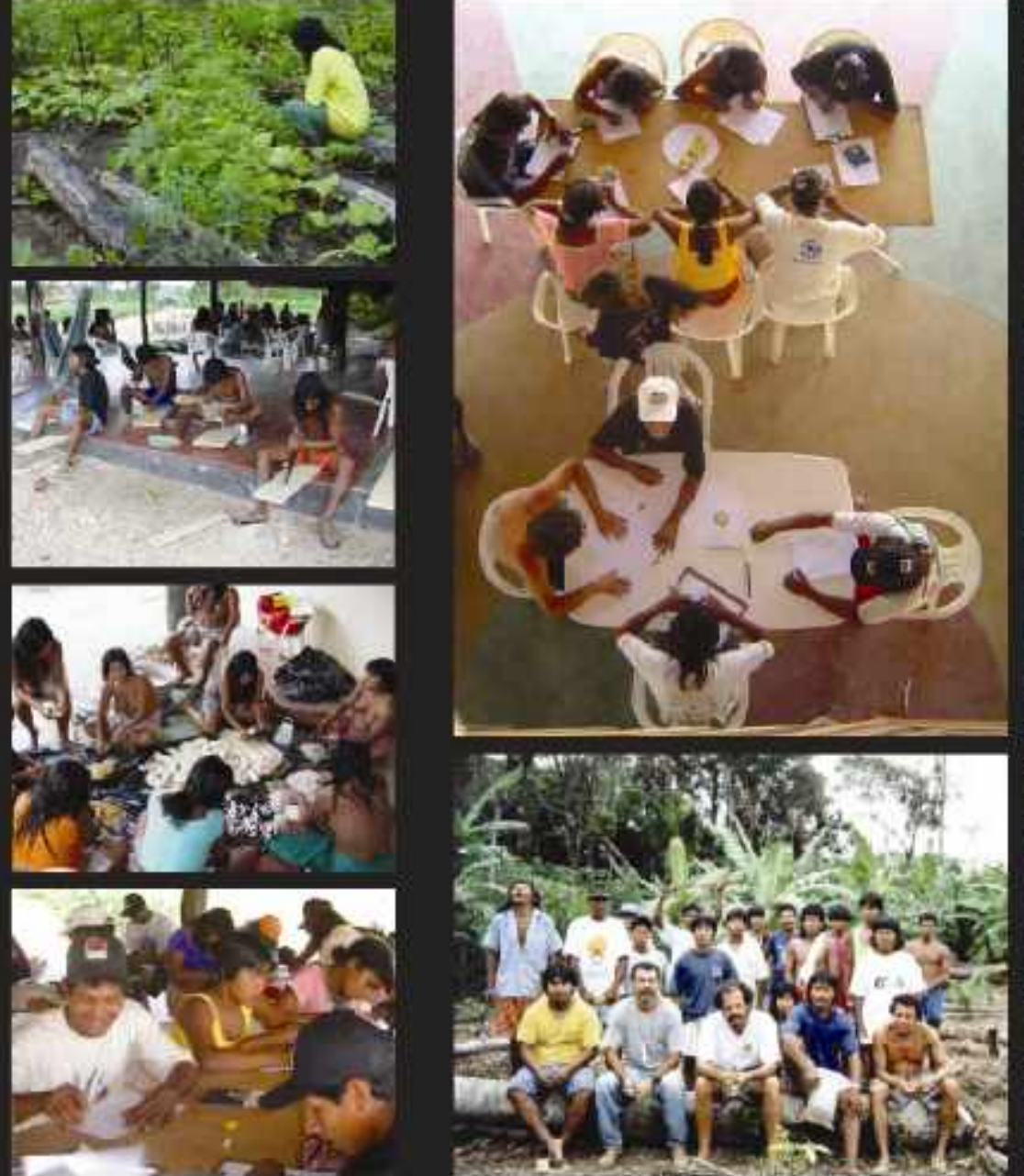

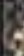
ESCOLA AGROAMBIENTAL CATXEKWYJ 
"Ghobiolog a e Conserworca de Recursas Ge. néticos e Sf gumnga Al manta dn Fina kmhis"

E im polaro desenvoluido cea Kancy on porcer a rom a FMBRAPs, cue tan por che wo resupers o consersar recurbos gathelicas lrodi cunais pora alime alaça e og iculura, assim

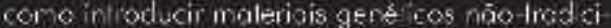
onais adaploweis as rondisses de solo e lina $e$ a teslunatione

mais intrimaso Wwa c=targen eribraga briantecikrato htm

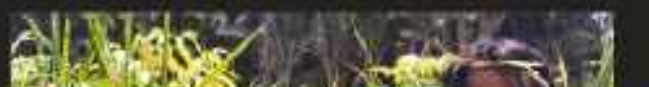

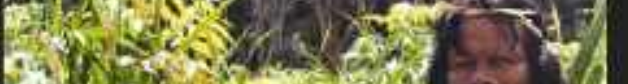

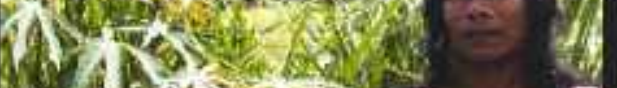
10.

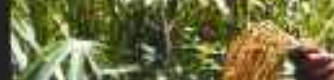
3e 30 .

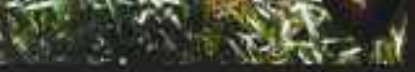
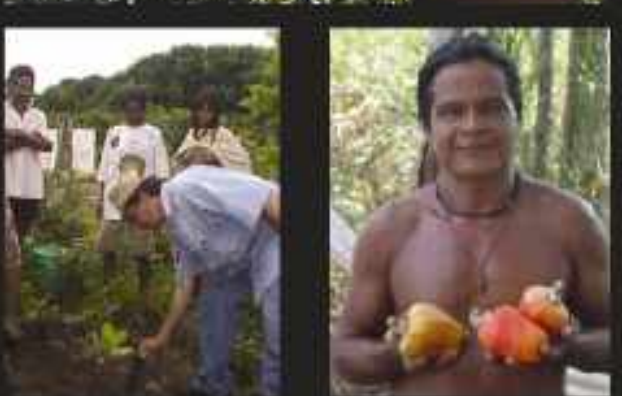
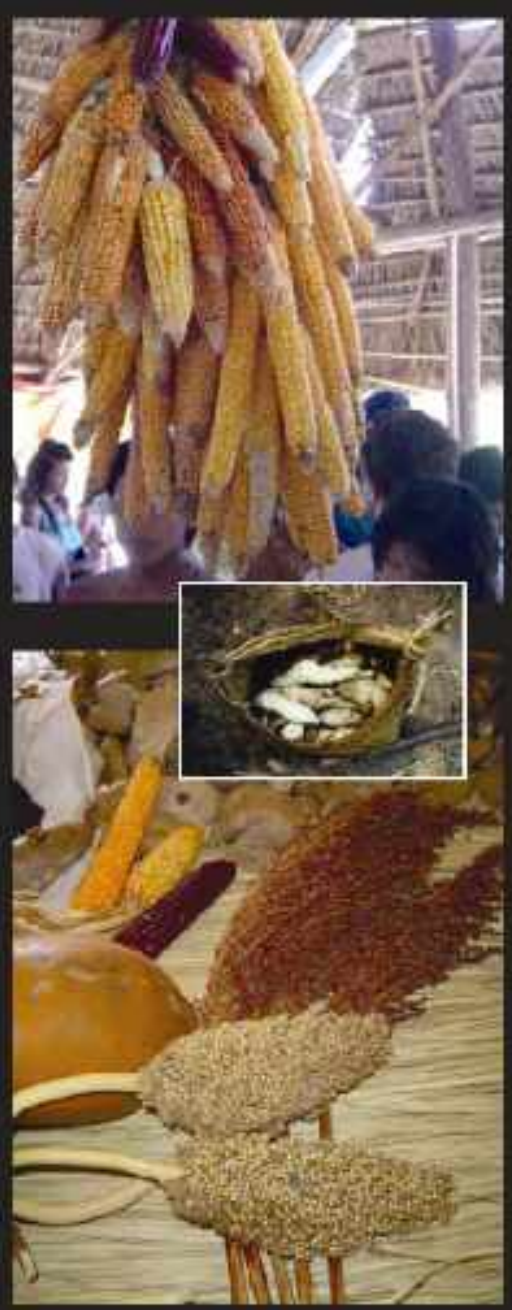

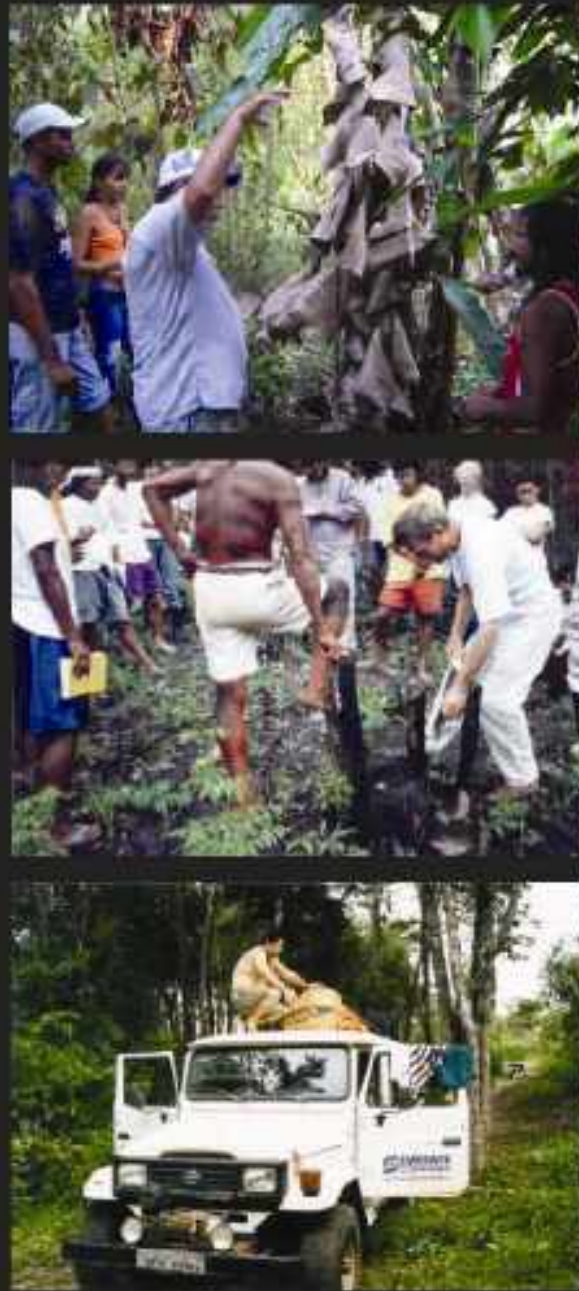

EMBRAPA

$30 \%$

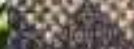

6060

$\sin 9.98$ 


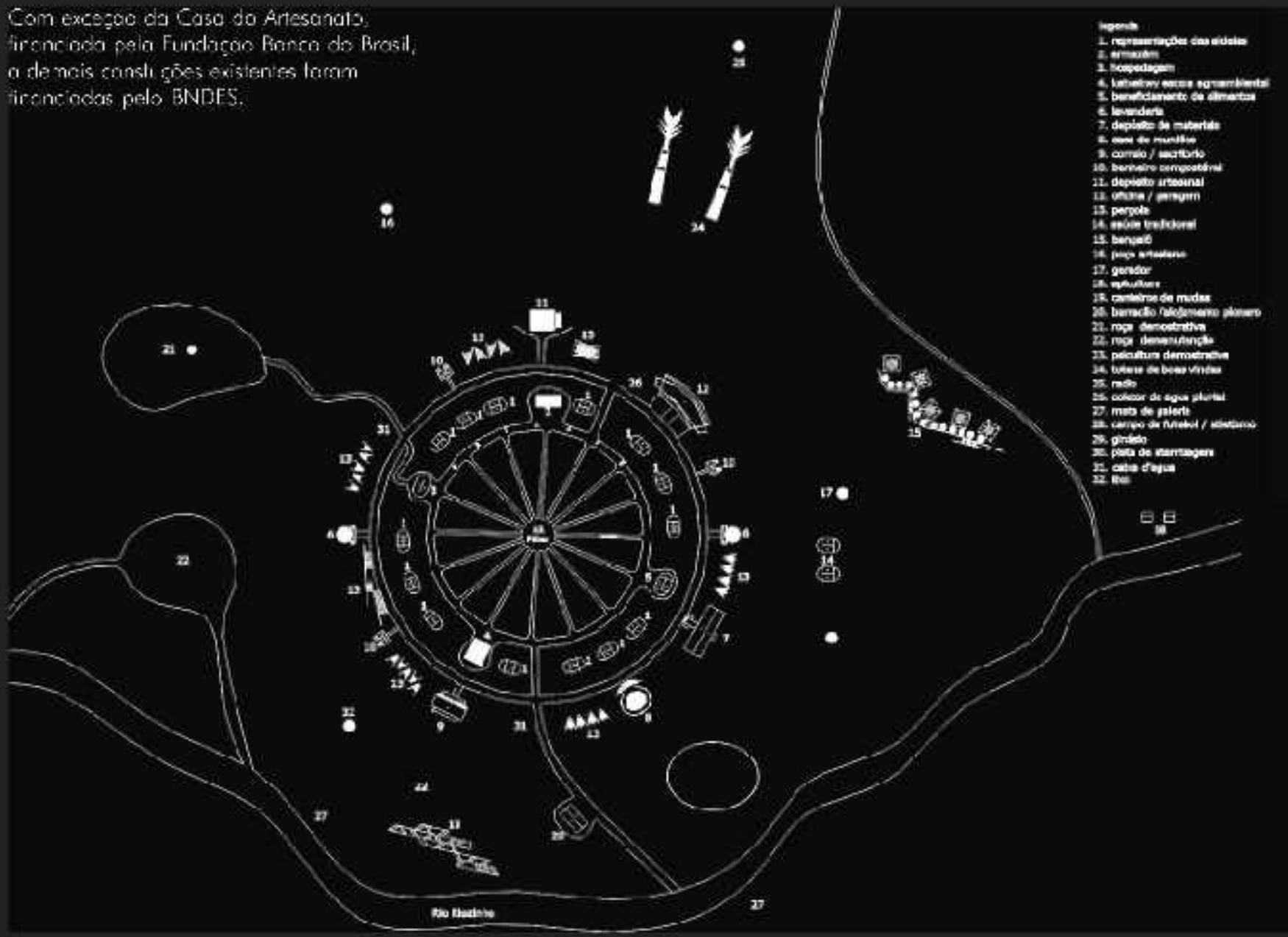




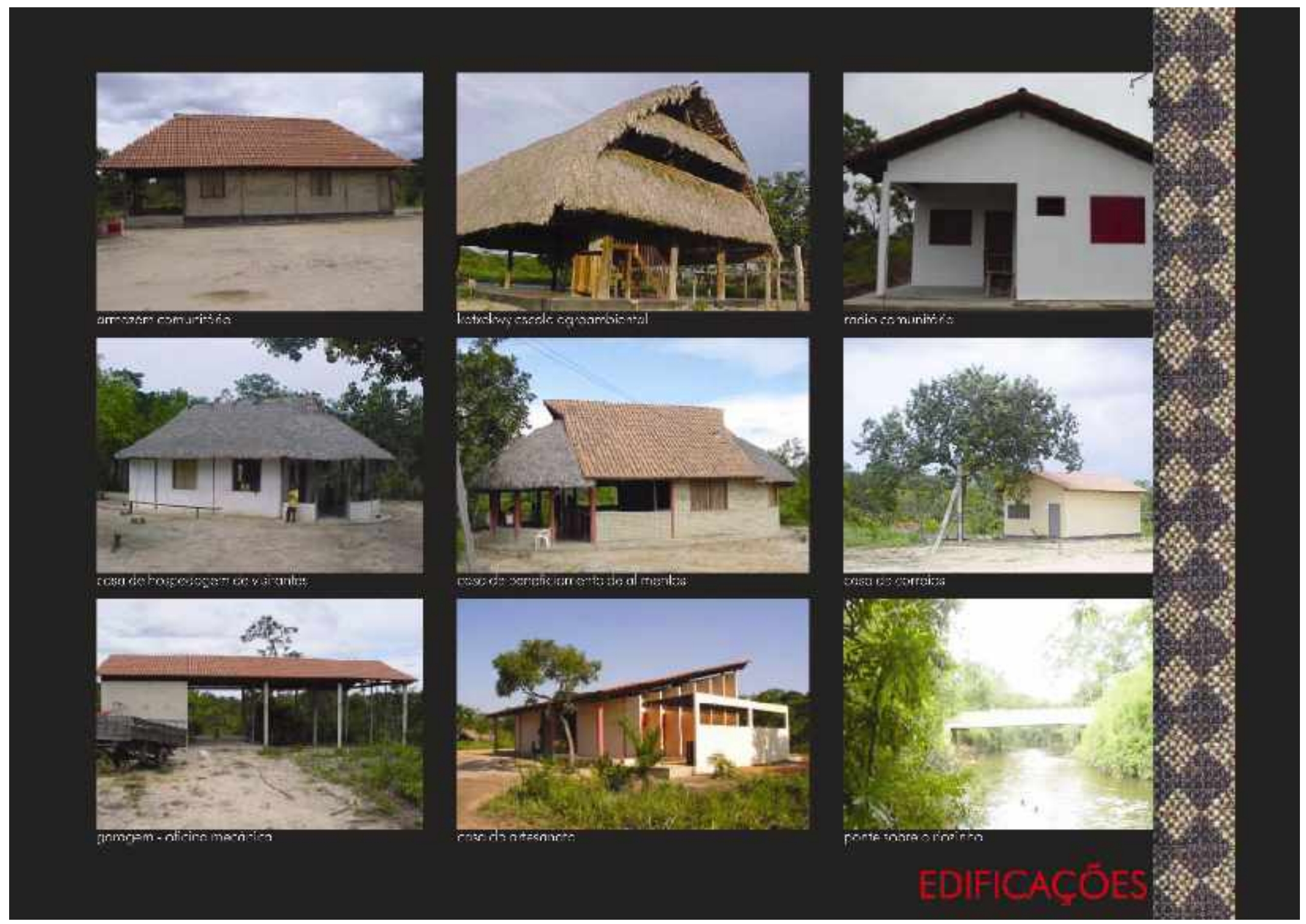




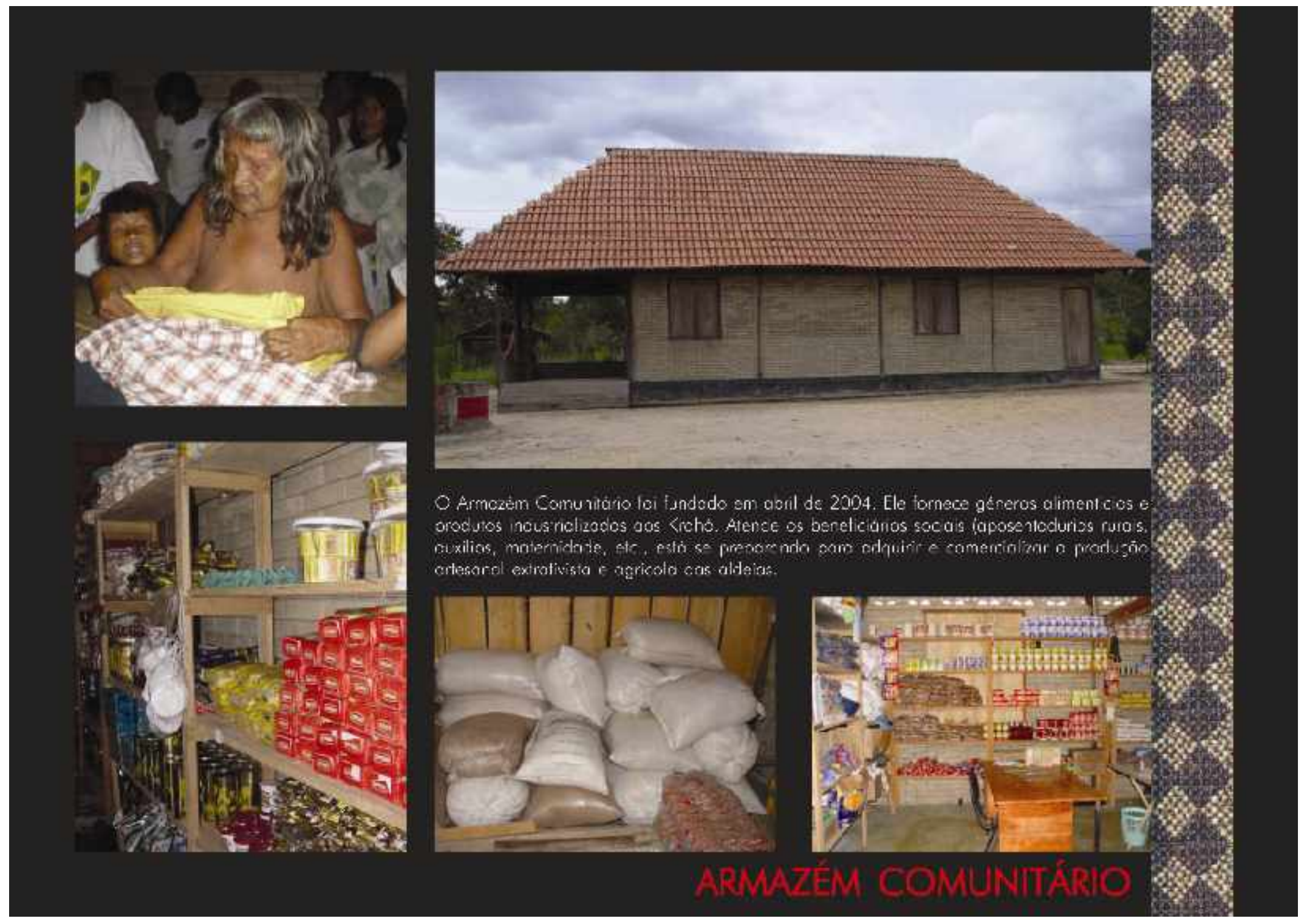



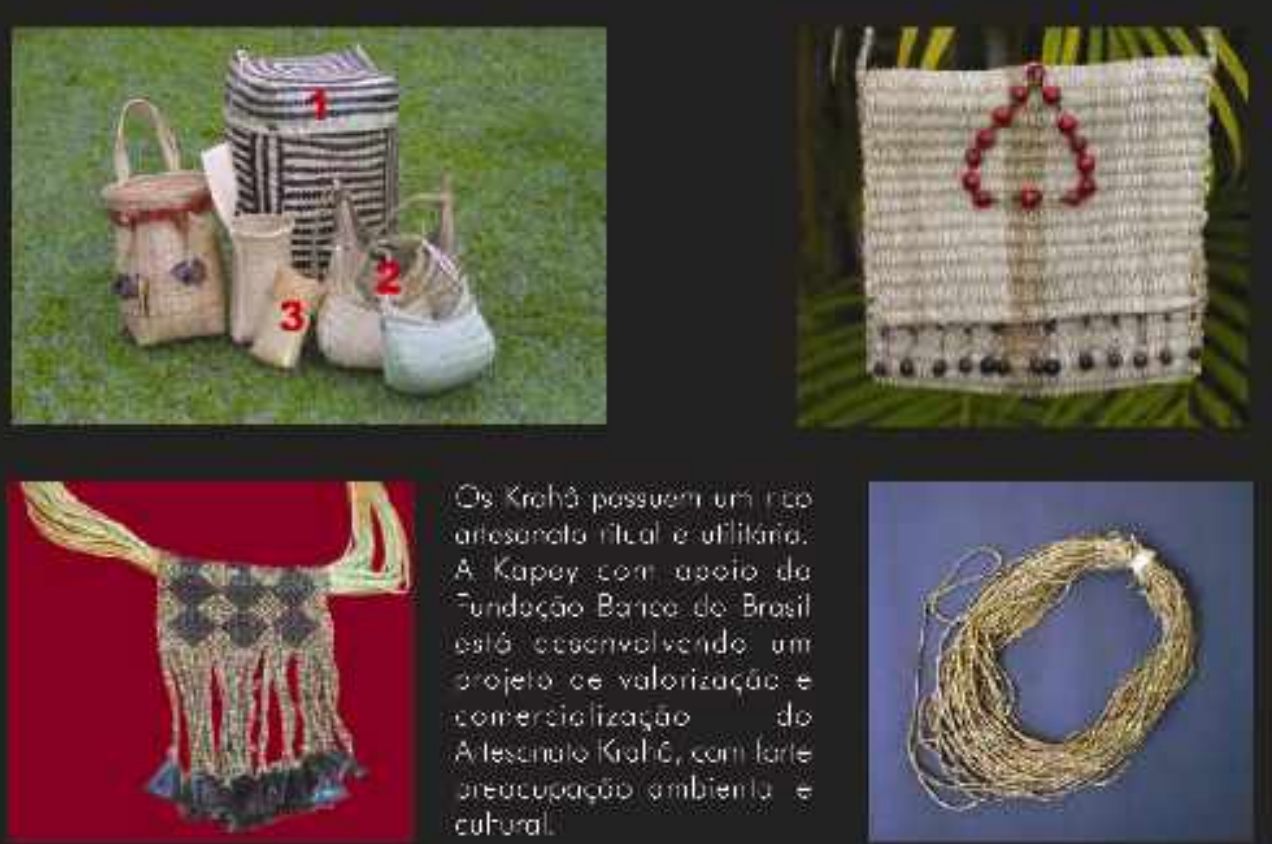

93. Kroke posguen un res chosumato tifua e ullikirios. A Kaper cen upcío do Fundecao Barec 60 Brosil sio ceocnrolsendo um wojeto ee ralorizaçu = comersicilicasáno do A lesinul kal $C$, son bite jertugaços ambiemle =
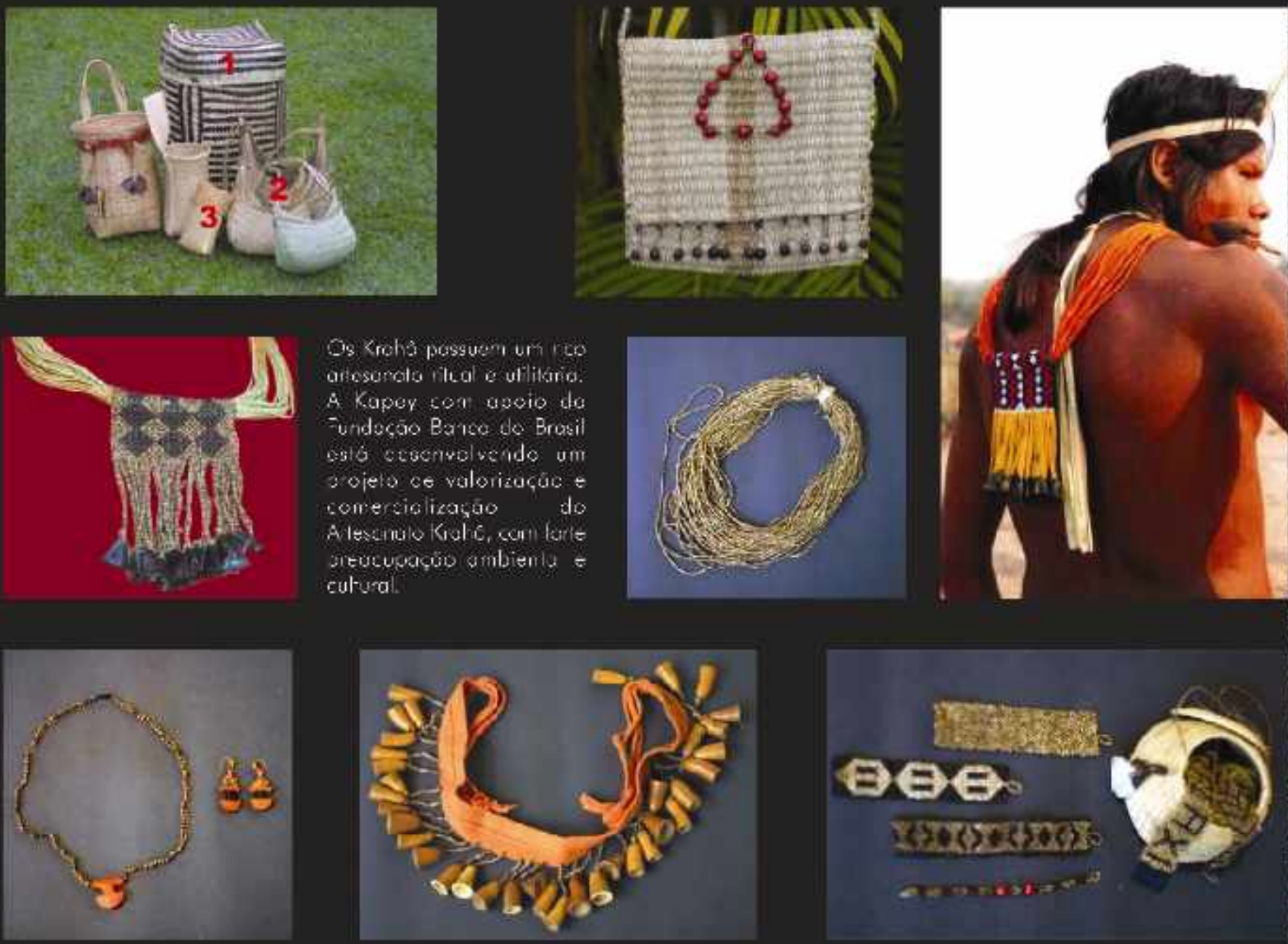

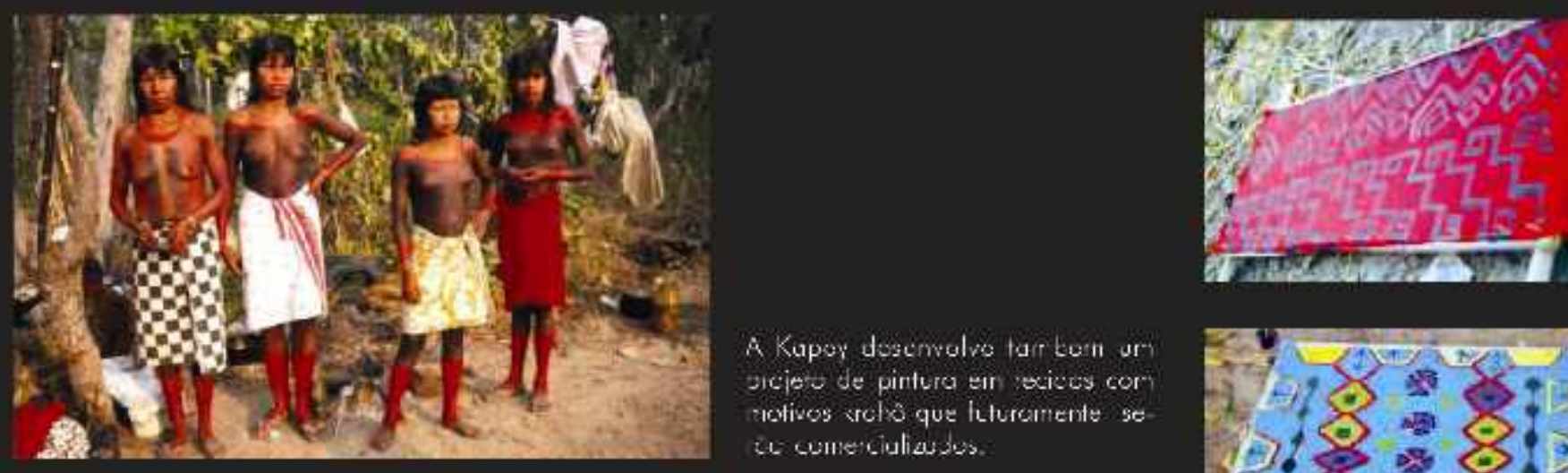

Q Kuper dosemolve tar bon ur jeies de pintura en soliess cor wotives arclis que hutumente se (L) cunetiuliases.
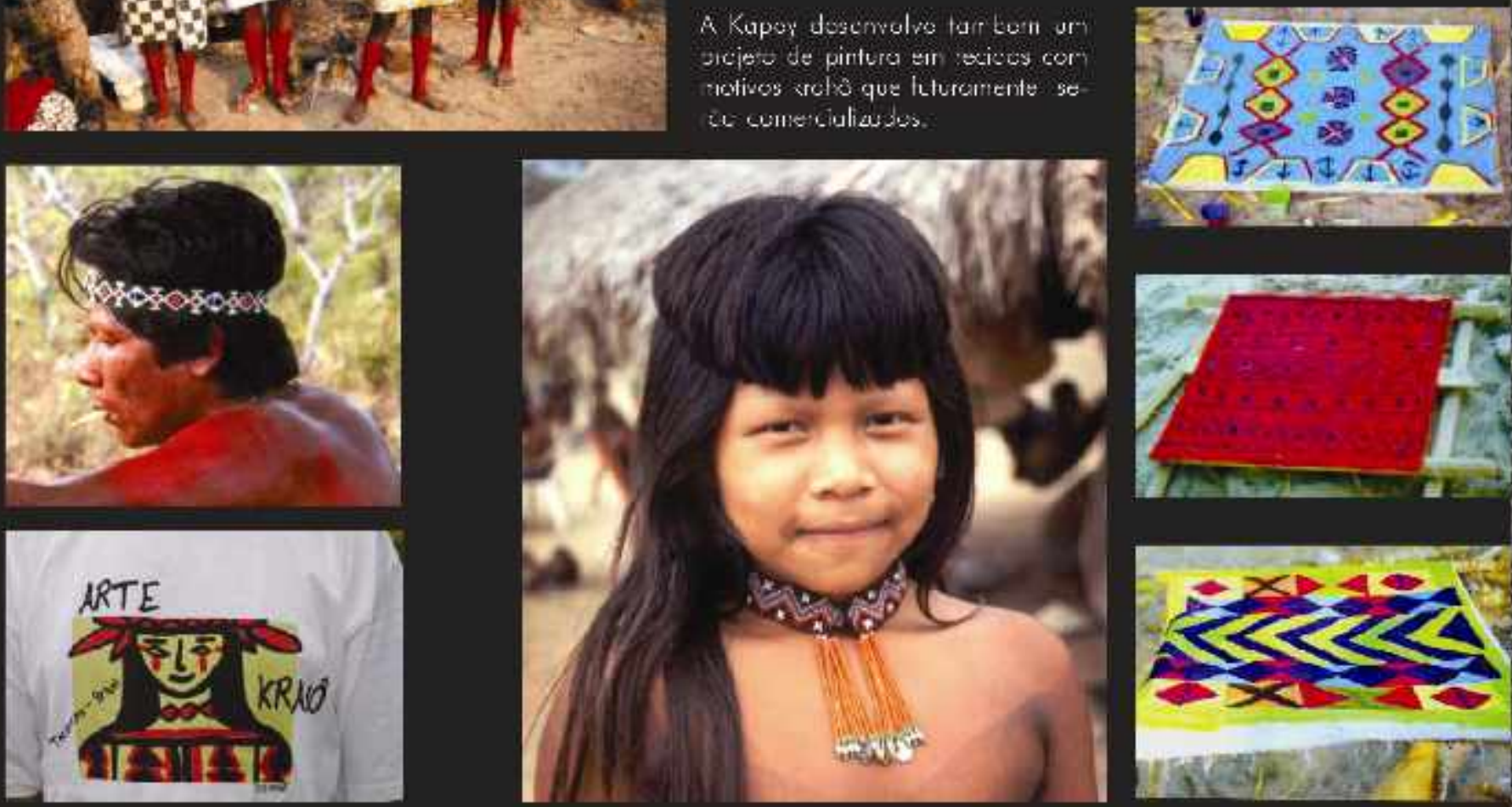


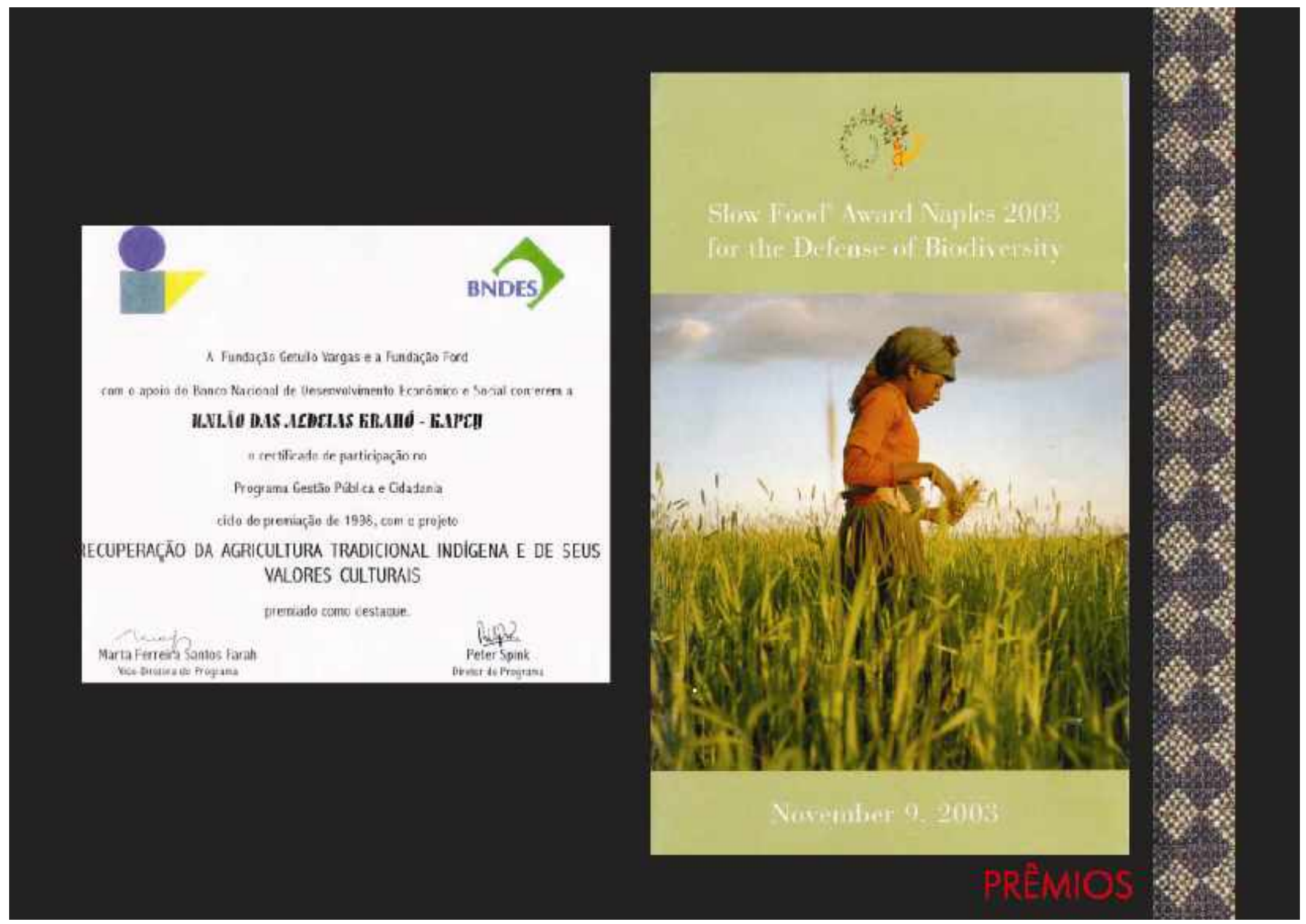




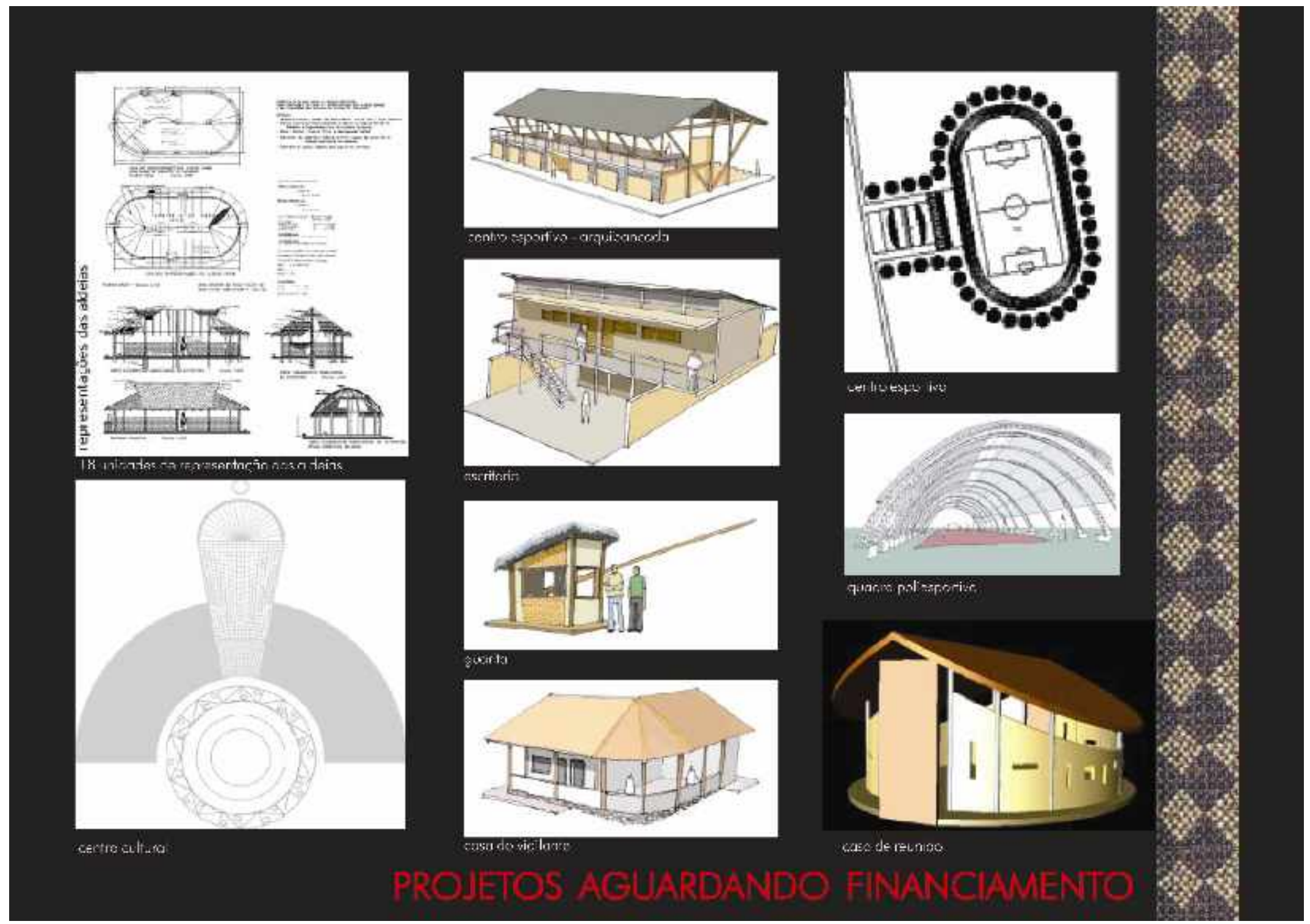


ANO DE FUNDAÇÃO 1998

ALDEIAS ASSOCIADAS: 18

NÜMERO DE ASSOCADOS 2.000 i toda a Fopu octo krohoi FINAIITADFS DA KAPFY

- Pramogoo ca cu vura deteso e conservagao de patrmóno historico e cultural das poves ind jenus

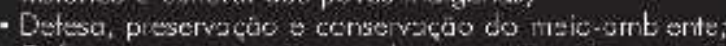

- Delesa e consemagád cos bers palrimanisis e lecriorisis co Fovo Kank

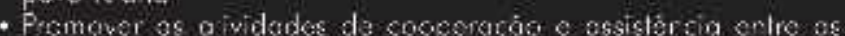
alow os icrota e destas -om as demos povos undigenas.

\section{ENDEREÇO/LOCALIZAÇĀO}

TCFMA I DOGLNA KNA IO

QEP: $\quad 77.720$-COC - HCNATO.

TEL: $\quad$ i63i 34391777

\section{COORDENAG̈AO AIUAL}

\section{Coondenzaso: Vise-Coordenador \\ Secrelsio \\ Antaic Bohikroc Krats \\ Osmar Peden Krahe

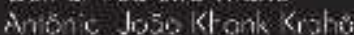 \\ resoustice: \\ Votar Aaren Orlondo Kats \\ $2^{-}$copution Visuelilo Kanke}

\section{ASSESSORIAS}

Fernoudo Sthimein Cleso Moroes

Carcos Sogods

Jussário Corzeco

Jirsses Moriteic

ec- Indiganistaj fun mi

Aux. Adminisirolize/ Lung

Agrinomo

Nutricionist:

\section{FARCERIAS INSTITUCIONAIS}

FUNAI

EMBRAPA Emoreso Erasilera de Pescasisa Ägropocuáro

UNITINS

UFG

ULBRA

FARF

Universidade do Tocanlins

Whiversidads Festerol de Cooís

Dhiversic ade suterand do losantias

jerns a no nutario

Fundaçāo Cultura do Estado do Tocontins

\section{ARTICULAÇOES INSTITUCIONAIS}

COIAT Gcorsenacáo oas Oganzazas Indigenos dos

COIAR

Gocremacáo oas Oganza Broslating

\section{FROIETOS EXECUTADOS}

- Lexantamento teral das Condieñes da Soíde to Populacõo Kralio $199 \% / 7978$

- Viglar cio e Contros da Termo Indigena Kanó - $995: 1996$

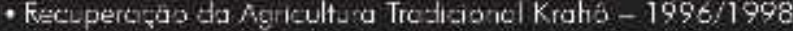

\section{PROJETO5 ATUAIS}

- BNEFS Progama Integrario Sacin Krite

- EMBRAPA Etrobiologia jagurango Alimentor no Fero Indigeno Kroho

- PPP/PNUD P calas e Frulos dos Gerrados Progranc de Pequencilin ete:

CATXKWY Yvenk a Anroumbienu

$-P^{P}$

comercizaçoo ds Aidescinalo Krahs 
EXPERIİNCIA EM EVEN'OS SÓCIOS.CULTURAIS

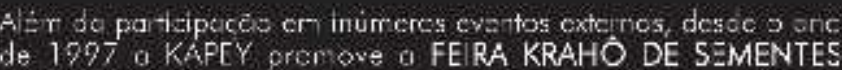
de 1797 a KAPEY premove a FEIRA KRAHO DE SEMENTES
TRADICICNAIS, que se reolizaca na sede ca entidode. Já forar

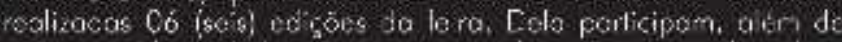

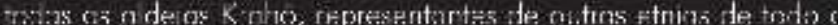
ogis Alen de semerites tic dionols, o fera e uma oporua dads

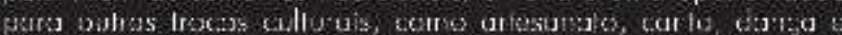
is 16 isios.

PREMIOS RECEBIDOS

- fundacáo getLllo vargas - agac fi. blica e CIDADANIAK $\quad 1598$

- SLOW =OOD - "TREMIO SLOW FOSD EM DEFESA DA ACROB ODMERSIDADE NAPOLES ITAL 2003.

FSTRUTURA FISIEA ATUAI

mow $=5$

- Escricir o ma eidace de itacojés

- Terena na víc de Alo linde

* Avmazer comunici.

- Escolrs Ägranmhertol

- Cosa de benelisiarrento de Al inento.

- Cona de Howsederiers de wisitant:

- Cuso de rasio Cununiaria

- Cara pa a Srupo Gerodor

- C.ticina meránion

WFi:Hors

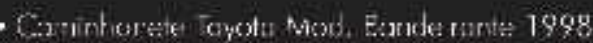

- Comint onele- Milsubishi ono 2000

- Trigr New-tolans 1999

- Tratar Mtassey Fersussn ano 2008

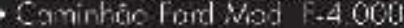

PESSOAL

- Contacar

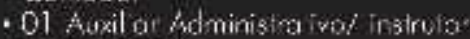

.01 Indige 1 stc

.02 Estugidios

- O3 Mronstas

- 82 ratoriste: 


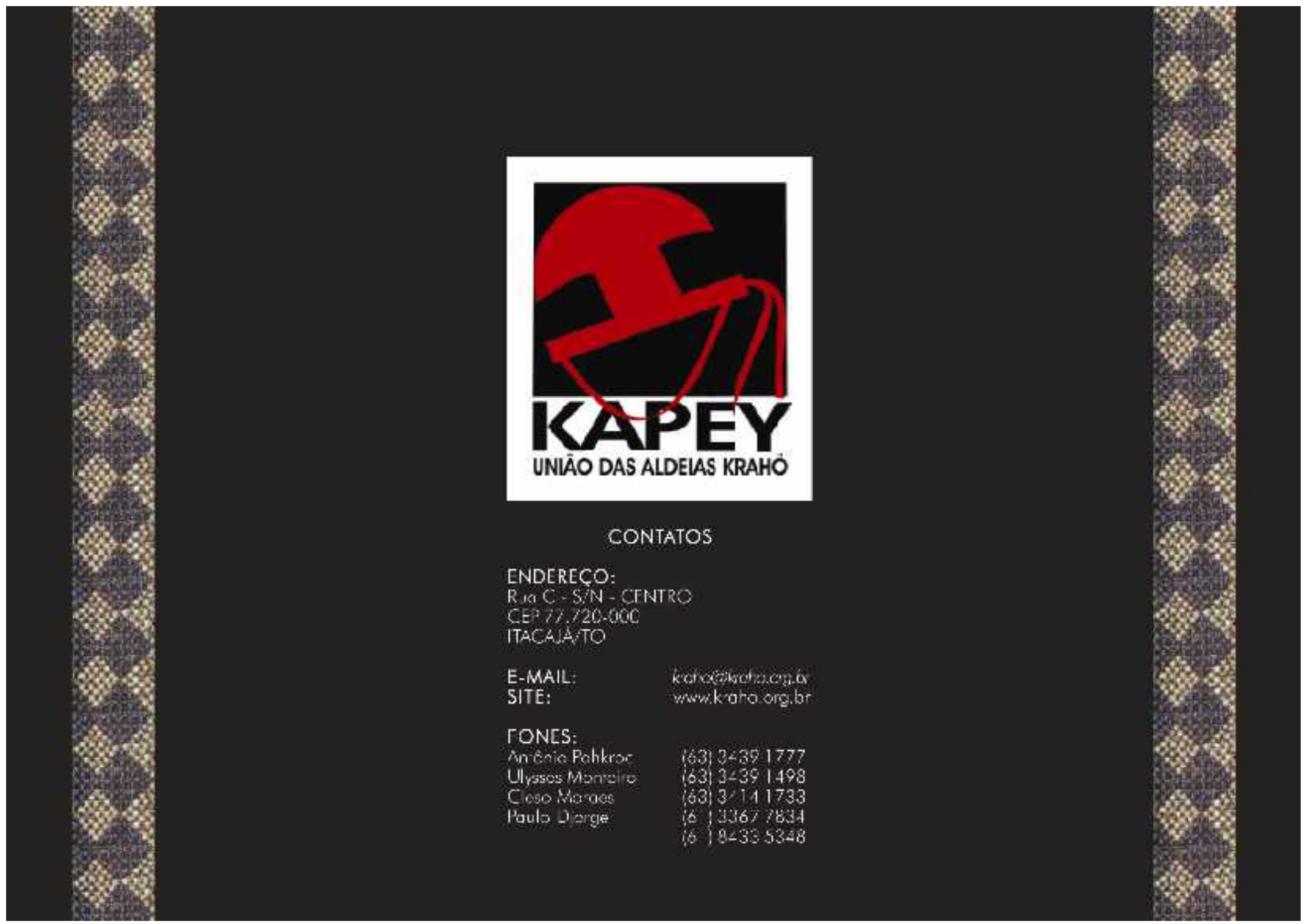

